\title{
日本醫科大學雜誌
}

第 8 卷 第 8 號 诏和12年8月15日䋁行

\section{色素性母玟, 組織學的研究}

日本醫科大學病理學郄空（主任: 福十呚授）

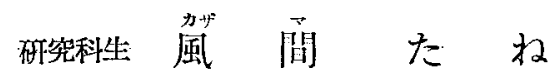

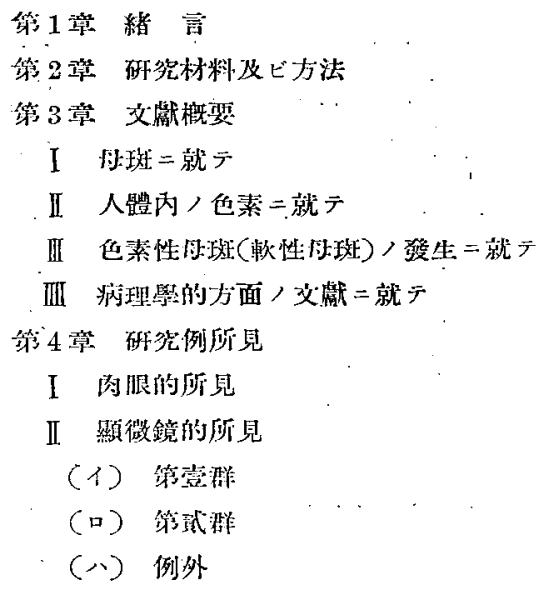

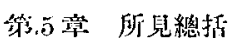

1. 闪腿的所見

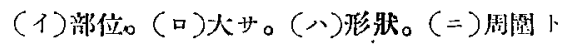

八關係。( 小) 色调。(へ)毛倠。

2. 㴶微鏡的所見

(1) 第䇺群 第一然一第六型。
次

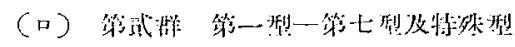

(八) 例外

第 6 境 溇 按

(一) 肉服的所見二就亏

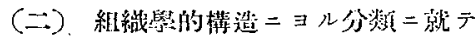

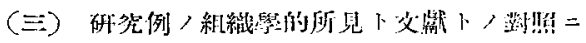
就テ

1. 伯 㑛

2. 躶状厤

3. 其底㷳

4. 乳弱㲊

5. 網桀鹰

6. 忙坆細脂

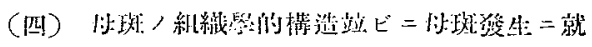

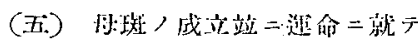

第7蹱 絬”䜊

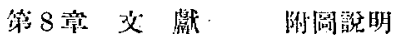

\section{第 1 章 緒 言}

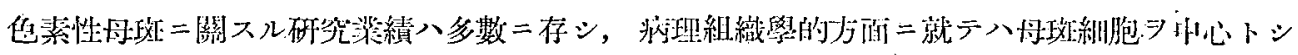

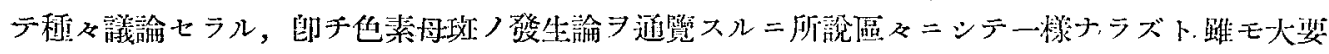

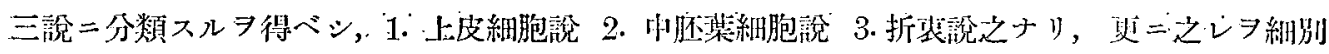

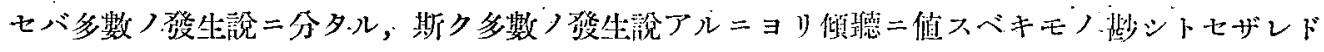

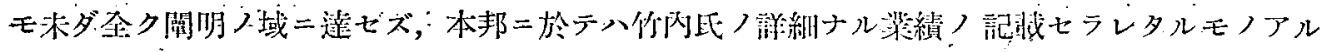




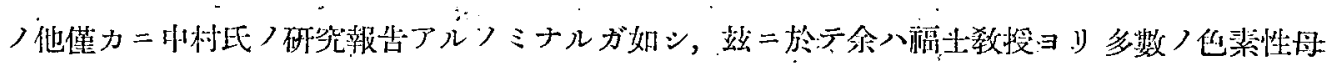

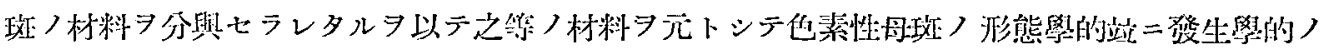

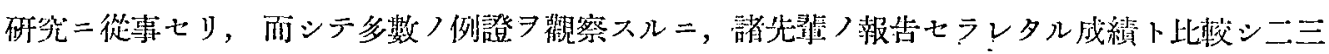

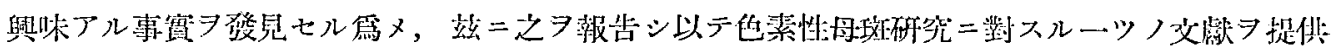

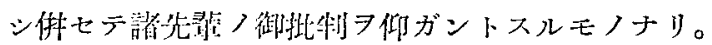

\section{第 2 章 犐究材料及ビ方法}

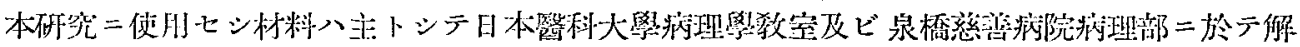

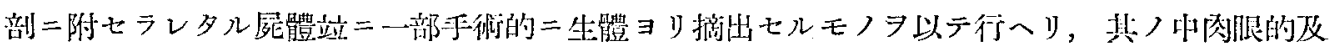

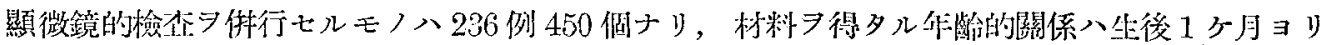

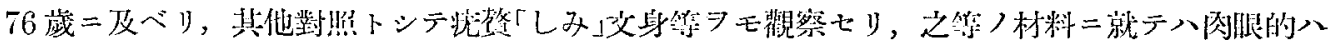

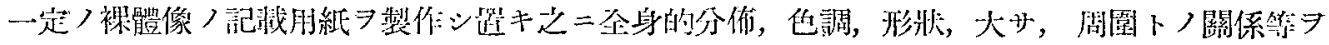

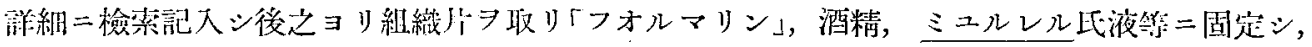

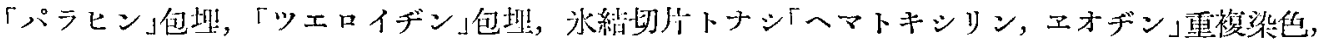

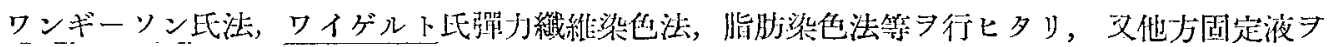

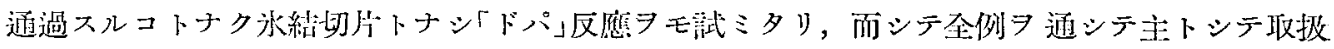

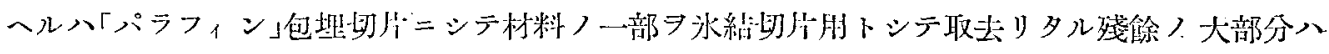

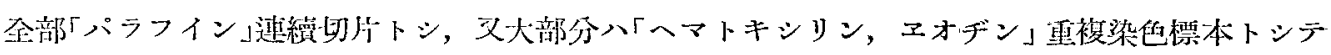

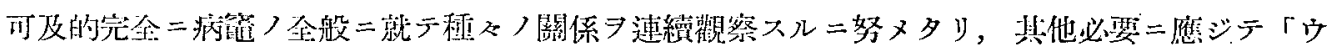
ンナ，パツペンハイム」此法，鍍銀洼等习脽ミタリ。

\section{第3 章 文 獻 概 要}

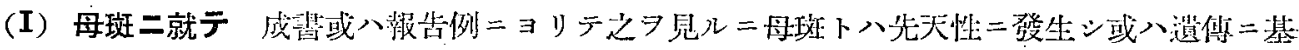

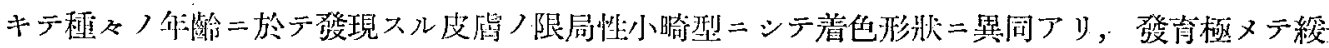

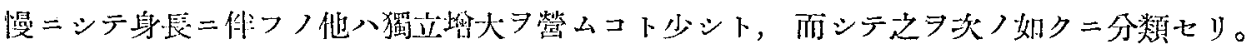

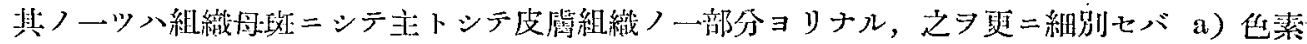

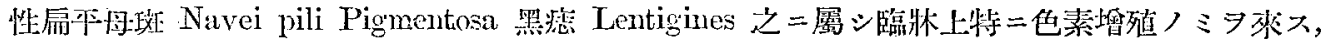

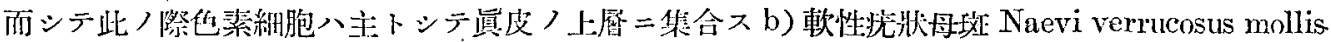
及ビ硬性犹狀母玟 Naevi verrucosus durus 肉哏上表面平等二又八炕狀二隆起シ，組織學的二

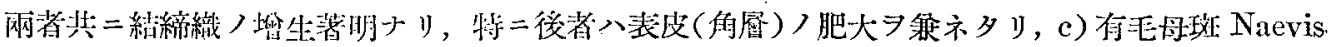

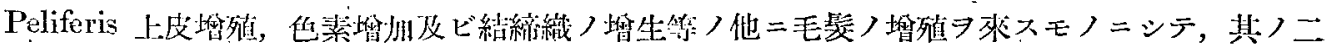

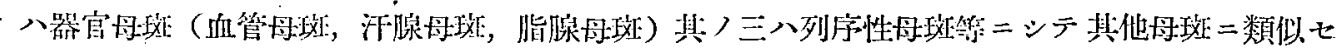

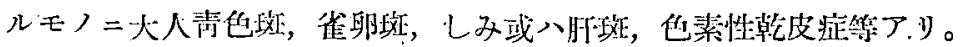

（II）人體內ノ色素ニ關スルモノヨ通閲スル二色秦つ種類八概ネ次〉如クニ分類サル。

1. 自篆成生色素 Autogene Pigment. a) Melanin「メラニン」ハ表皮及ビ所謂色素細胞 Ch- 


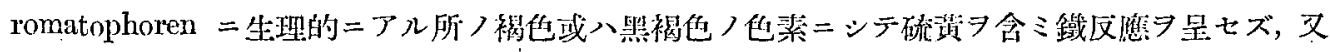

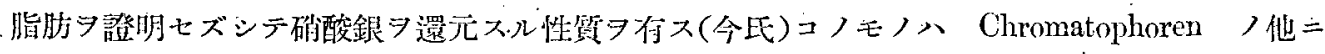

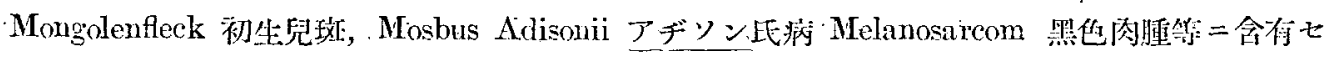

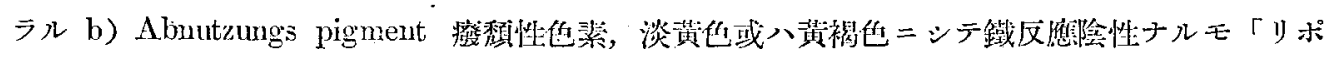

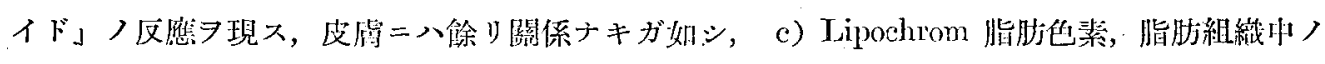

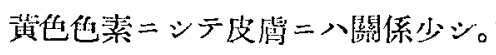

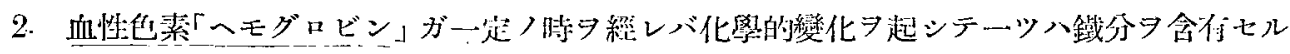

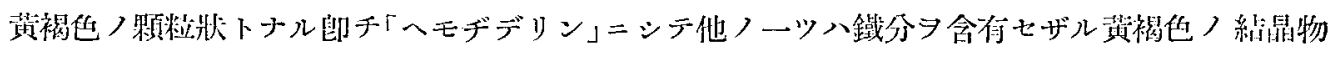

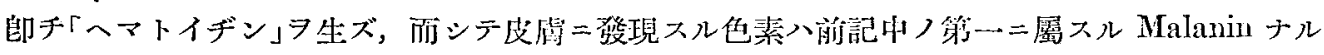

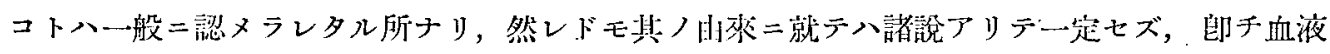
二H氷ストナスモノ = Aeby Bivuabacher, Browicz, Demiéville, Elaeser, Ehrmann, Ecker, Fuclis, Guzsenbauer, Kohlden, Langhans, List, Mare, Meyer, Meyersan, Opjenheimer, Ruland,

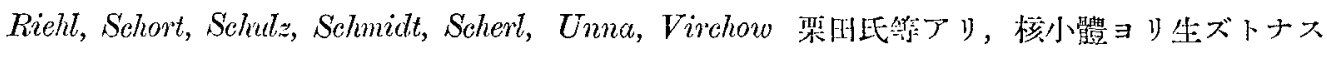

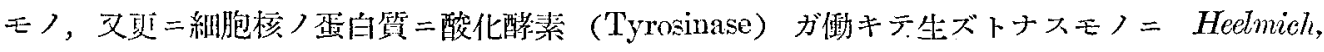
Jarisch, Mertschting, Meirowsky, Ritter, Rossle, Szilz 及ビ Bonrquelet, Donagh, Halle, Terus-

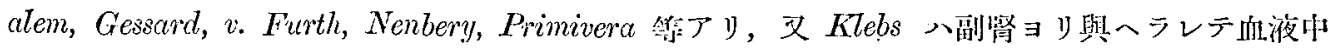
二存スル Melanogen ガ一定細胞中二含マルル他つ物質下共同シテ細咆內ニテ形成セラルトス。 以上ヨ姴大ル フ二ットナル，即チ皮牕內ノメラニン」八表皮細胞內ニテ製七ラルトナスモノ＝Beckey, Bauer， Baumgarten, Borst, Caspary, Donagh, Dyson, Dalli-Fauera, Elesser, D. Evans, v. Furth, HeIlmich, Jarisch, Kaposi, Kodis, Kromayer, Ktelis, Loeb, Mayerson, Merirowsky, Merzschling

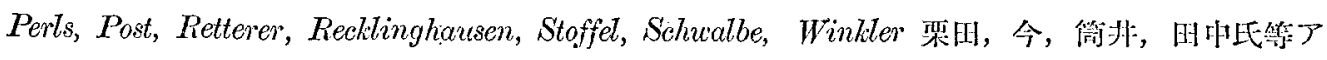

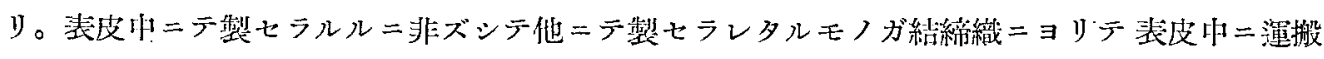
セラルトナスモノ =Aeby, Biedermann, Ballowicz, Blaschko, Ehrmann, Eberth, Giovanin, Hetheimer, Joseph, Kreibich, Kerbert, Karg, Rahlden, Kölliker, Wermann, Zimmiermann 势賀, 山極氏等アリ。

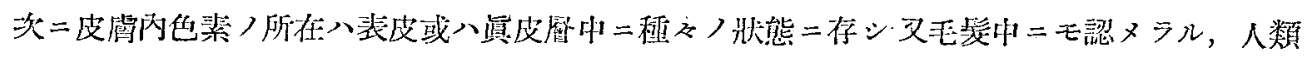

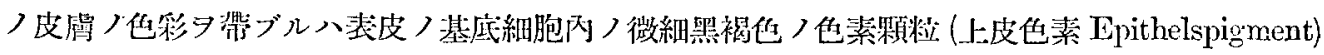

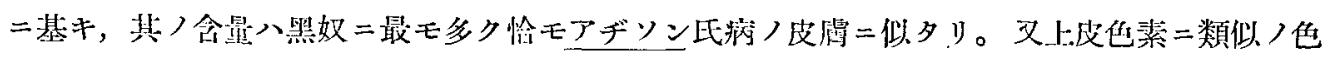

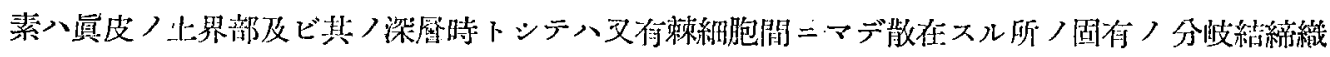

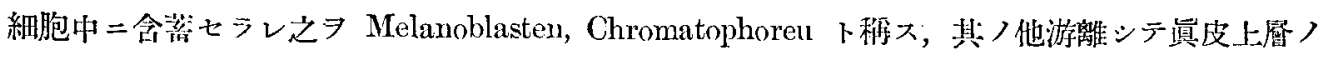

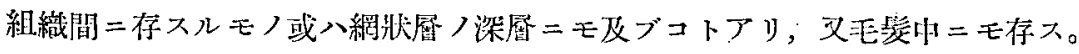

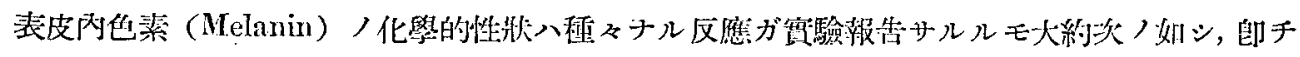




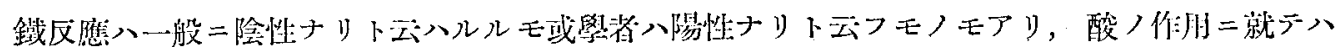

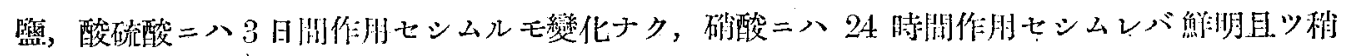

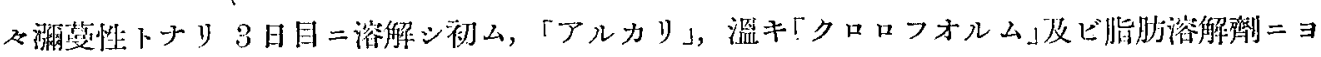
リテ色及ビ形状〉變化見ズ, 而シテ「ズダン」III 及ビ「ニルブラッ」二看染七ズ。. $3 \% \mathrm{AgNO}_{3}$,

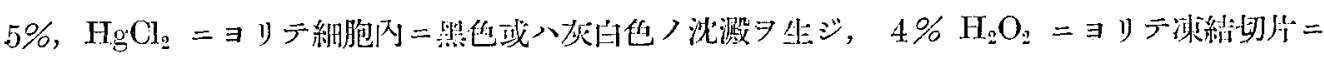

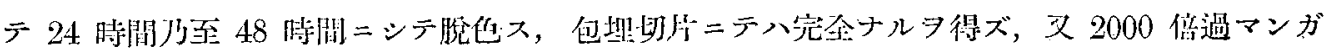
ン酸州里液 ㅈ.

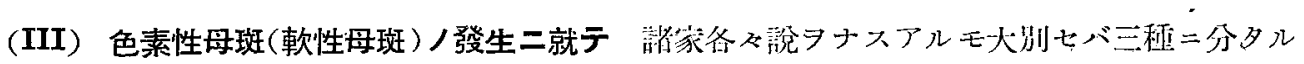

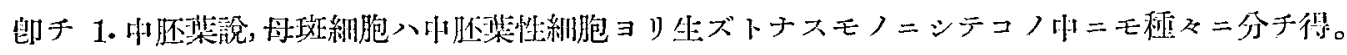

a. 胎生的結縍織細胞ヨリ生ズトナスモノ=

Birsch-Hirschfeld, Hansemann, Pini, Polland, Riehl, Rieclee, Rolitansly, Simon, Virchow 等厂リ。

b. 血管队被細胞ヨリ生ズトナスモノニ

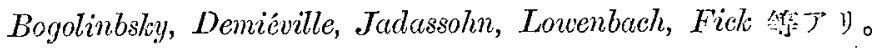

c. 淋巴管內皮絒胞ヨリ生ズトナスモノニ

Bawer, Borat, Heing, Johnston, Green, Recklinghansen, Ziegler 等アリ。

d.「クロマトフオーレン」ヨリ生ズトナスモノ=

Ribbert, Wiener, 筒井, 速水氏答アリ。

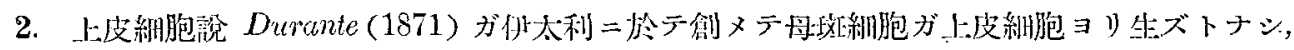

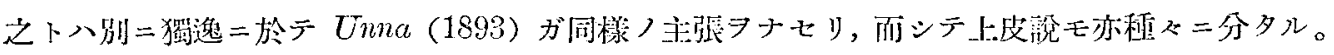

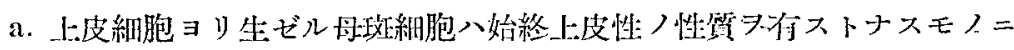

Abesser, Audry, Berblinger, Fick, Dalla-Favera, Grahl, Hermann, Kissmeyer, Kreibick, Marschand, Migriolini, Ravogti, Ravenna, Poltis, Schaleck, Uuna, 竹內氏筙了リ。

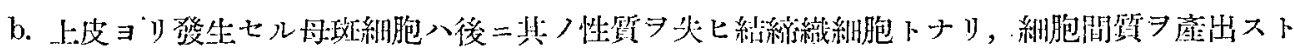
稱スルモノ =

Jndalewitsch, Kromysecker, Kromayer, Scheuber

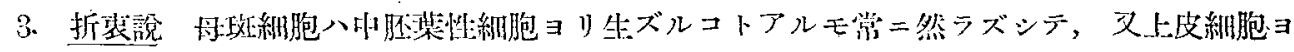
リモ生ズルコトアルベシトナヒルモノニ

Bonemann, Fox, Hamdi, Herxheimer, Kaufmann, Häller, Schmidt, Wieting 梁田纸等厂 .) 。

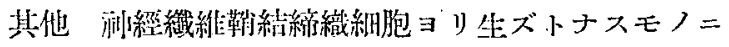

Abesser, Berblinger, Handi, u. Weiting, Soldan 


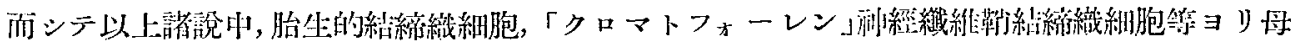

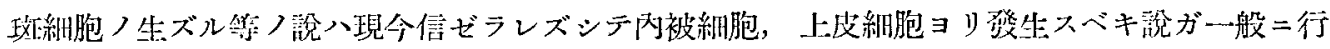

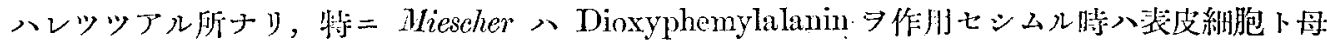

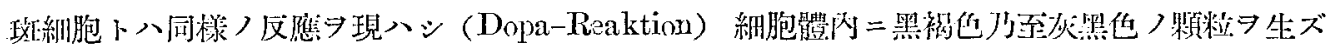

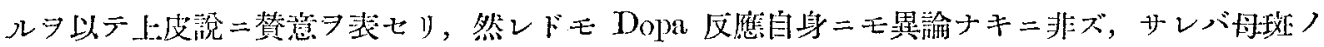

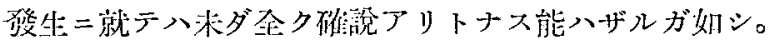

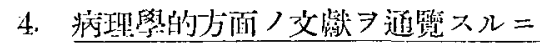

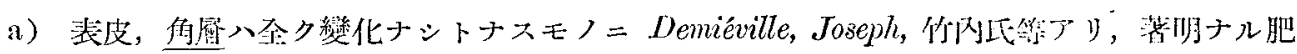

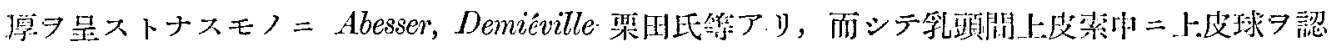

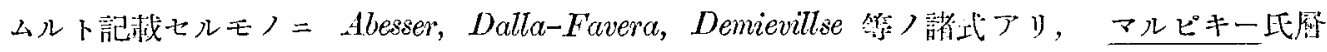

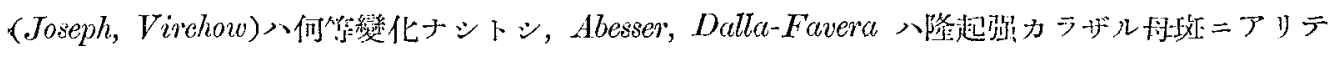

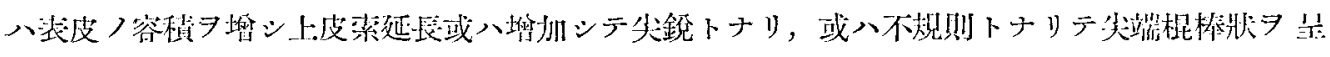

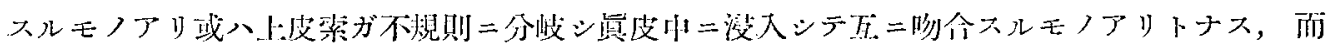

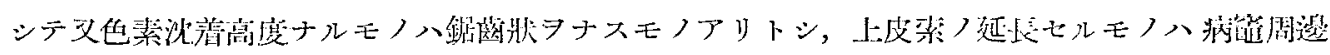

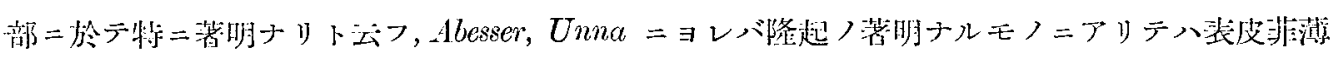

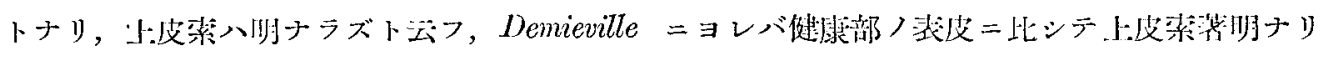

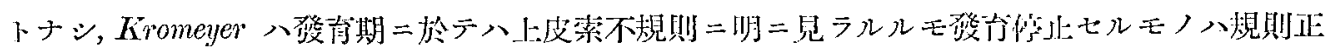

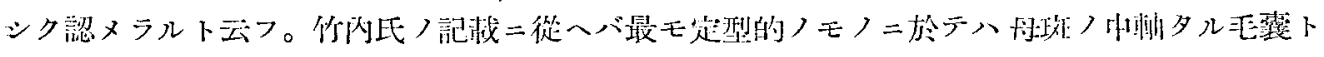

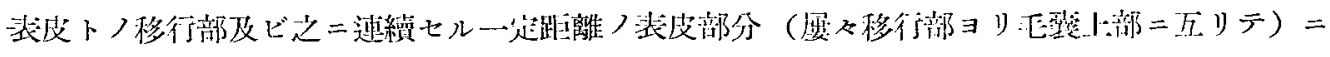

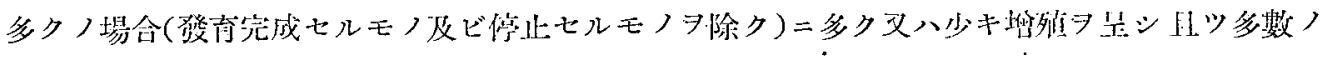

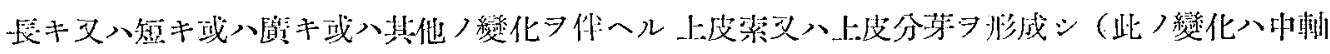

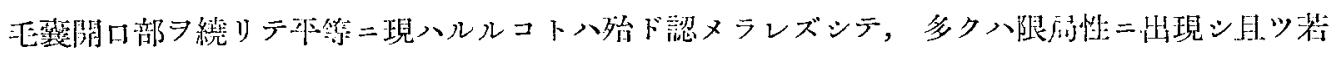

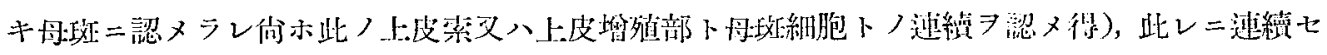

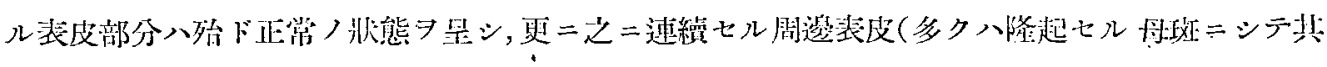

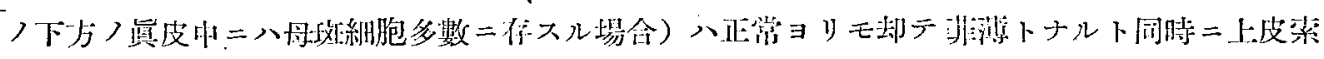

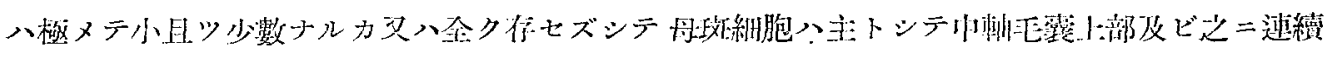

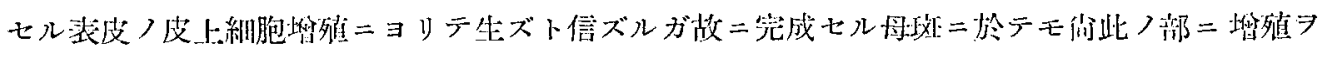

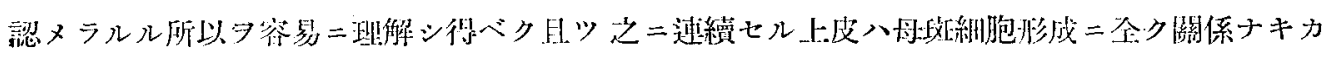

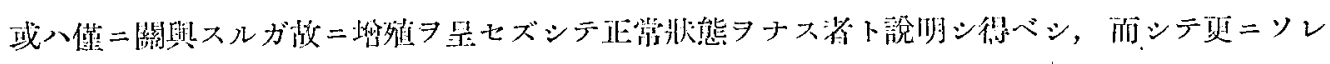

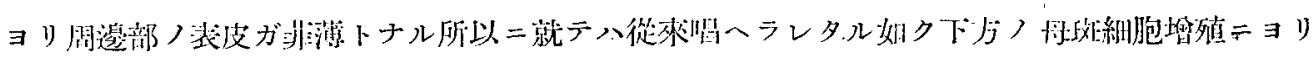

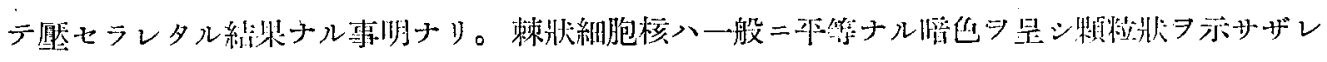

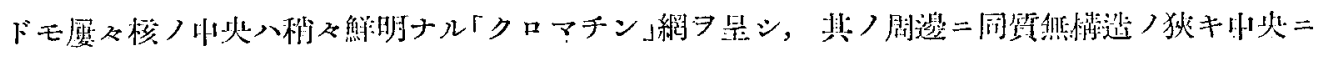

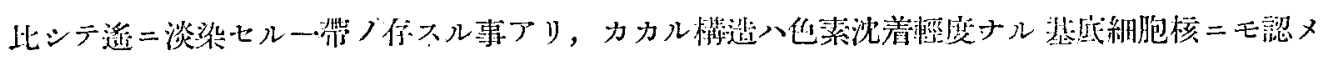




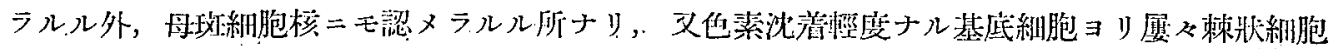

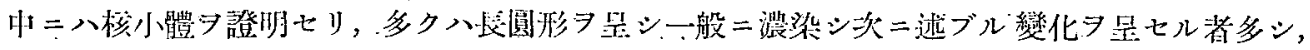

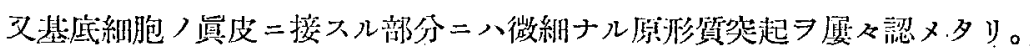

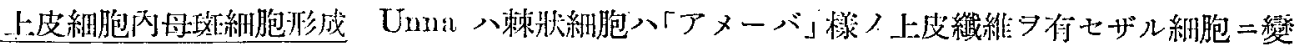

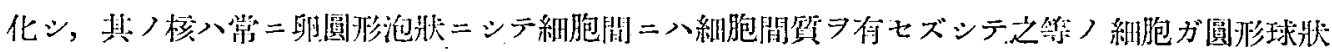

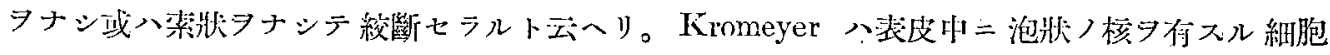

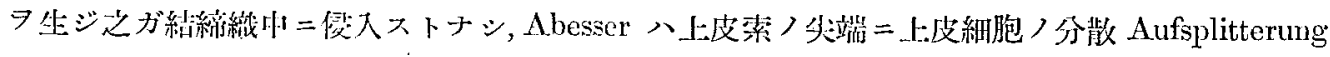

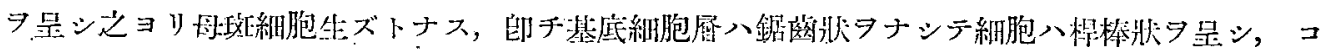

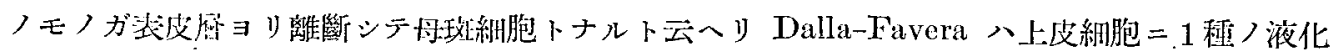

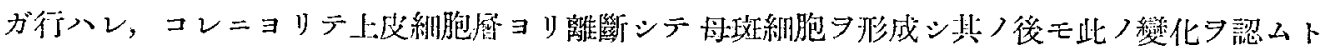

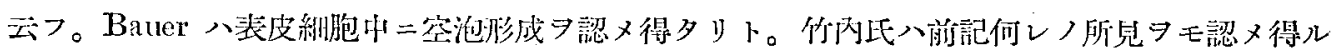

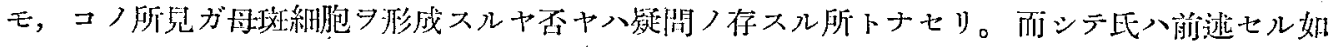

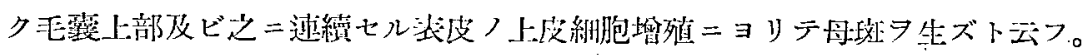

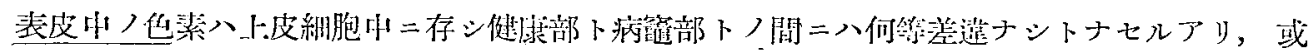

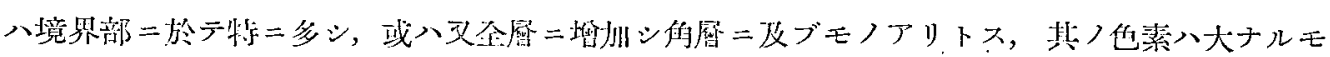

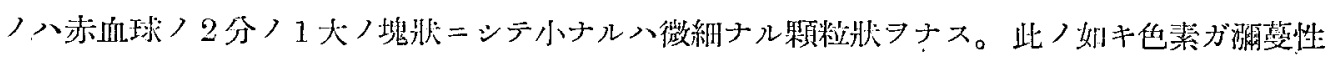

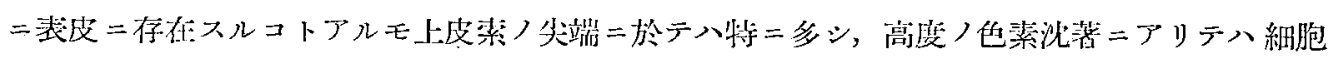

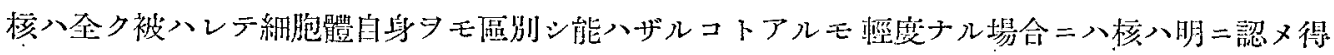

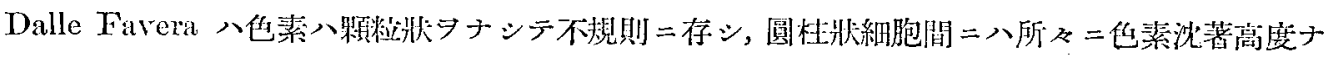

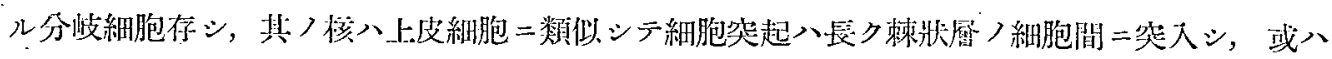

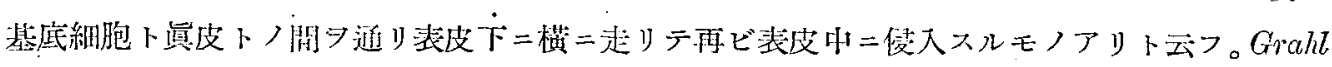

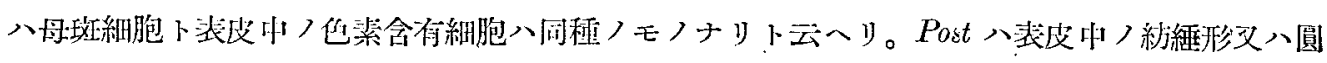

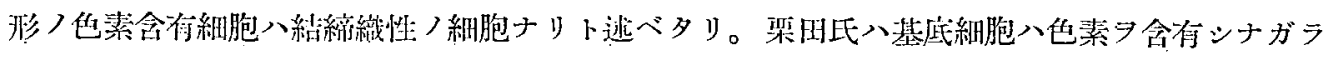

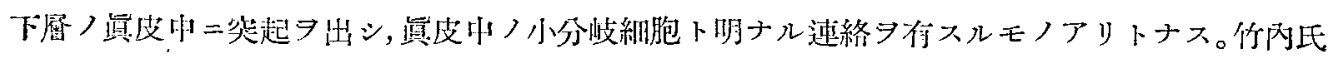

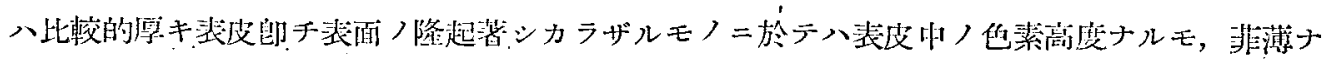

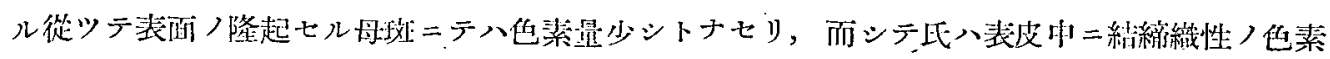

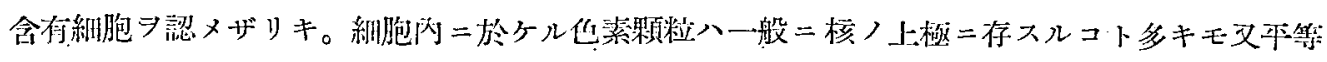

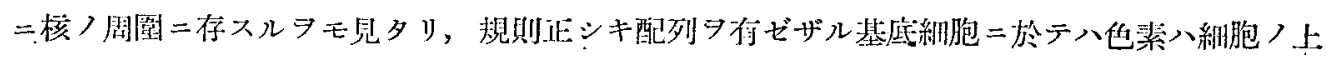

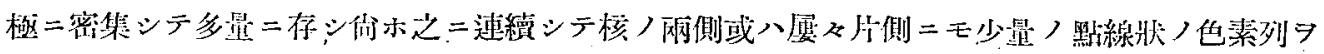

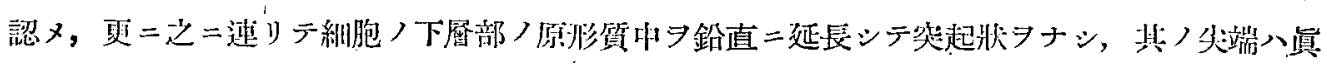

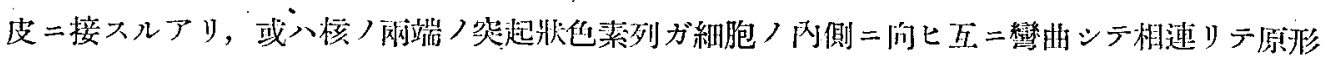

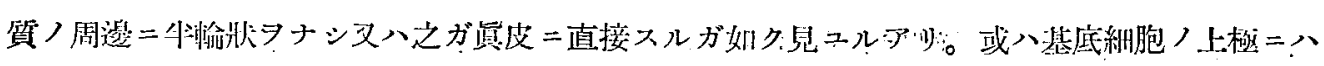

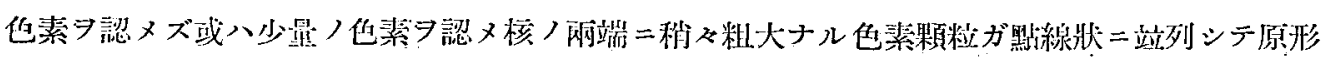




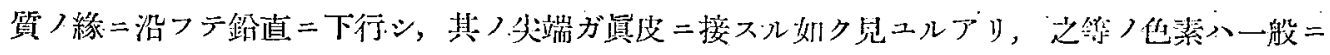

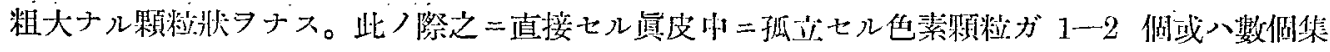

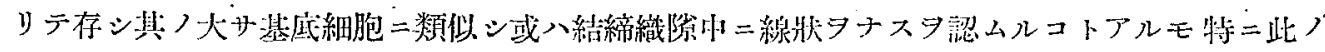

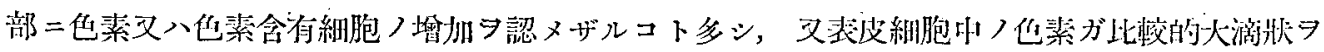

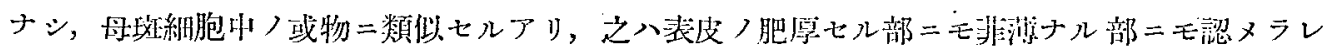

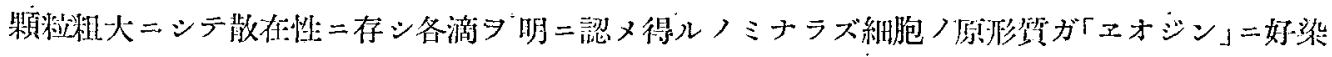

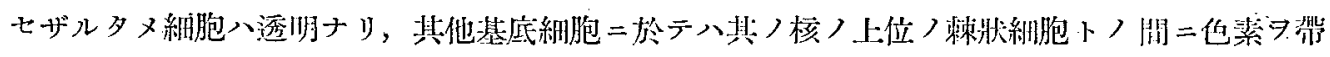

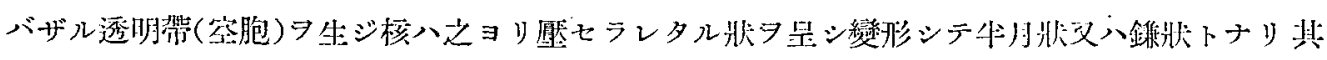

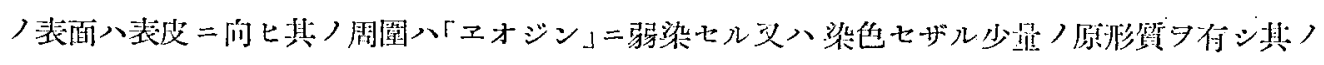

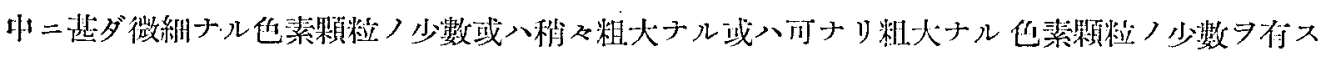

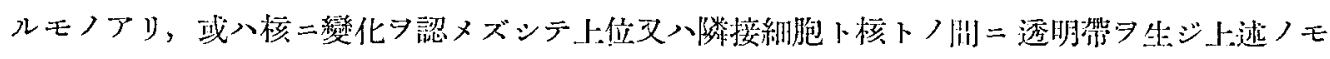

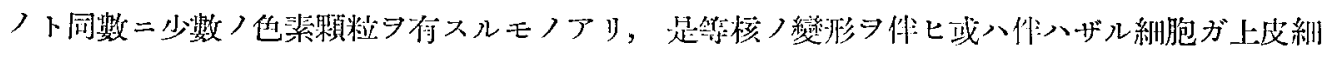
胞列ヨリ離レテ僅カニ一端二於テ逨ルガ如キモノアリト云つ。

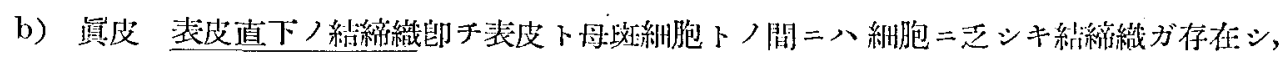

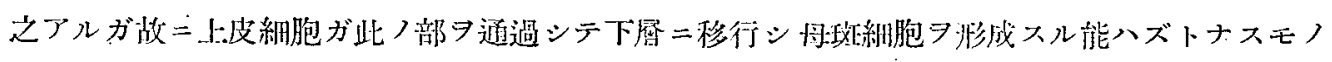

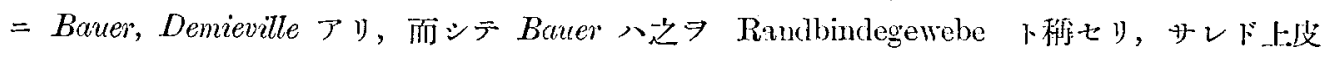
細胞ガ此ノ部

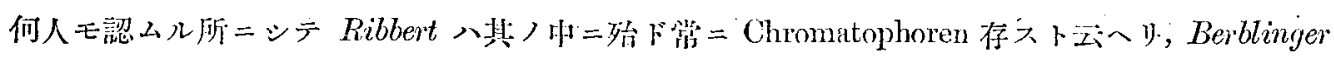

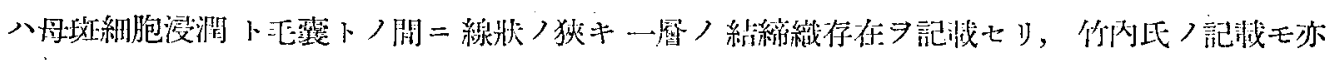

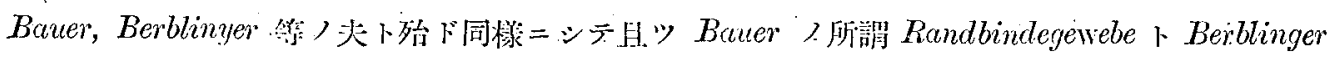

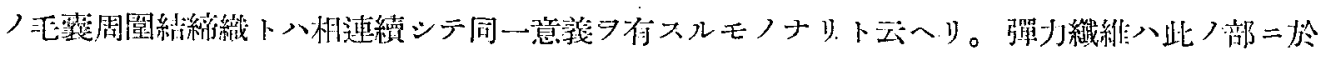

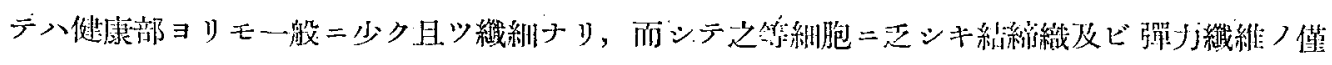

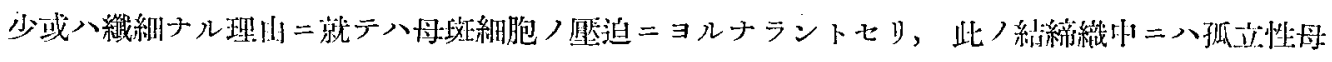

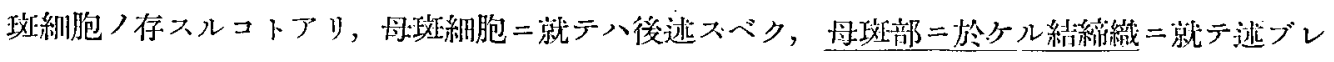

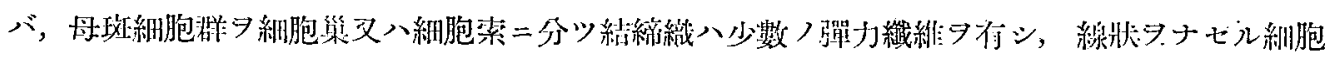

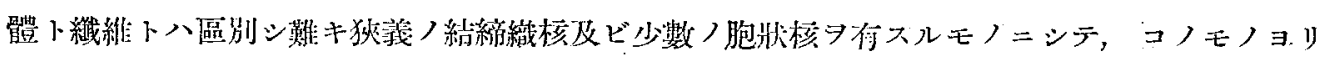

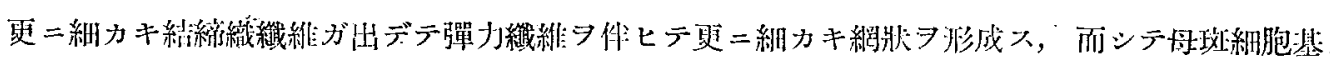
底二涉行シデ波状甲ナ七ル結䌇織存入（Abesser，Bauer，'Brost，Dalla-Favera，Judalewitsch， Kromayer, Löwewbauch, Oppenheimer, Ribbert Recklinglansn, Sẹeuber, u. s. w. 而シテ此)

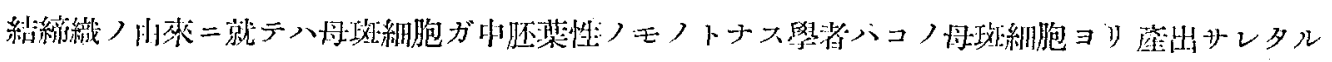

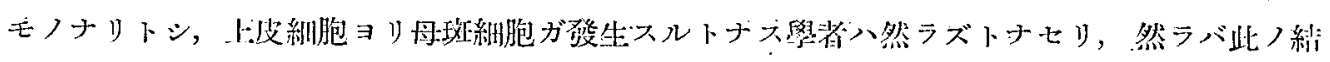

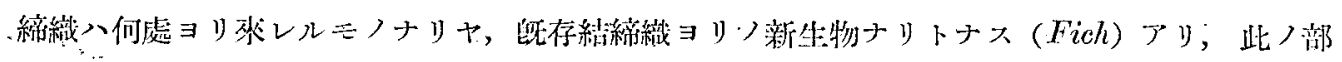

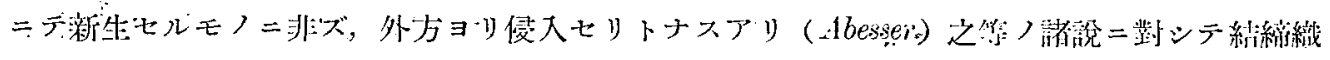




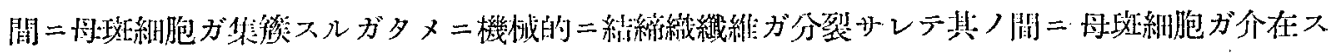

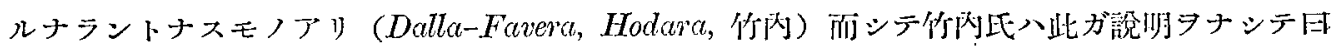

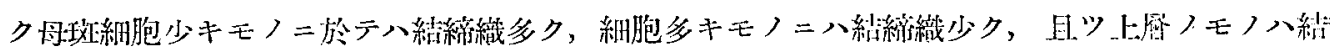

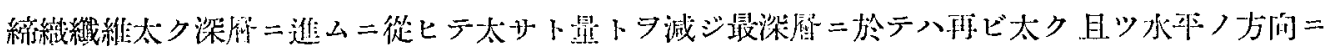

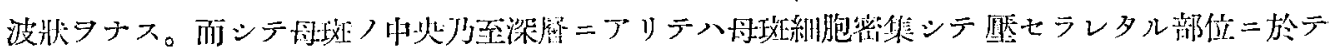

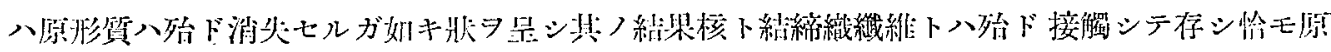

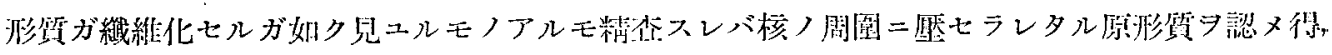

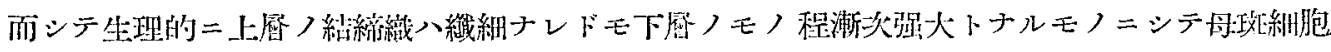

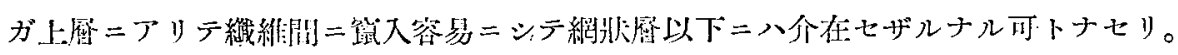

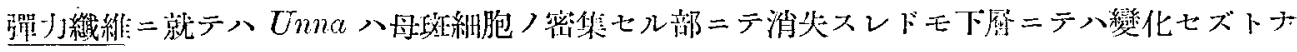

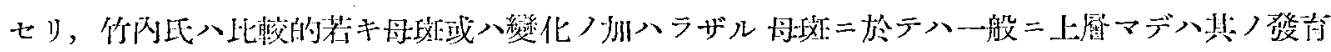

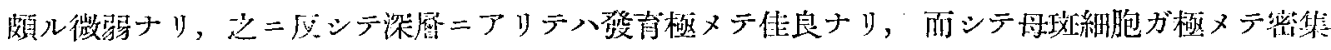

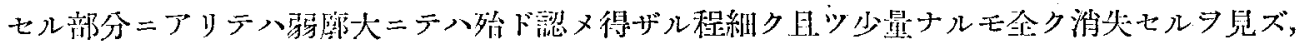

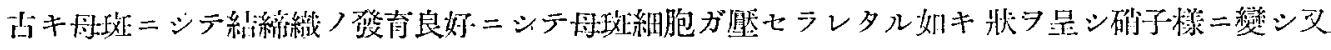

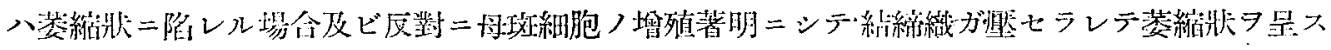

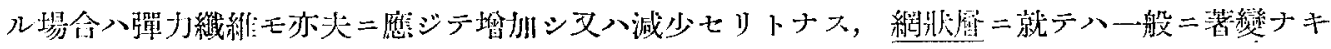

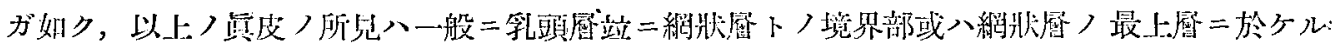

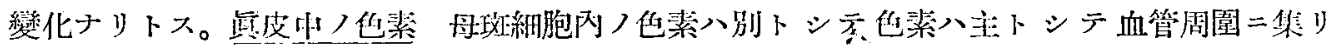

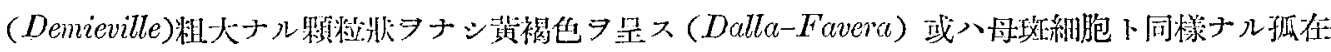

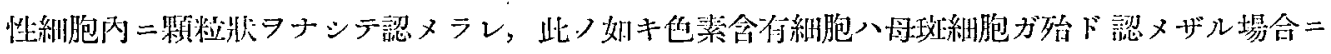

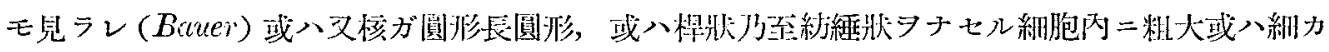

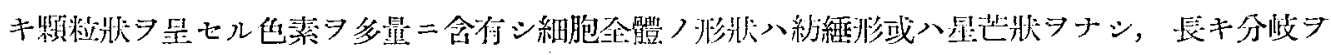

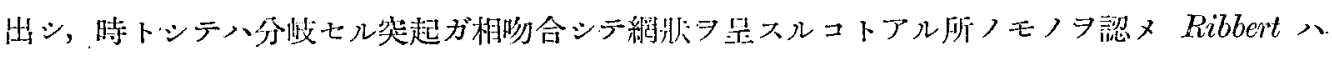

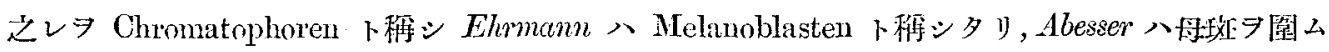

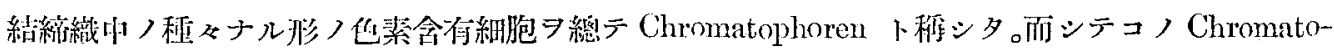

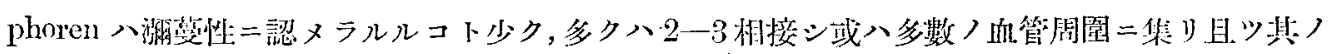

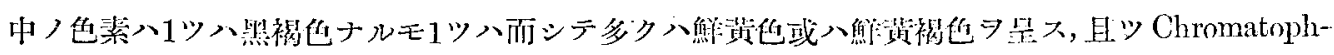

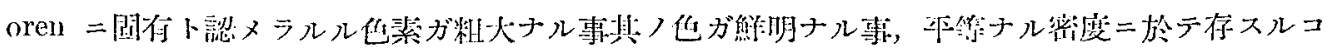

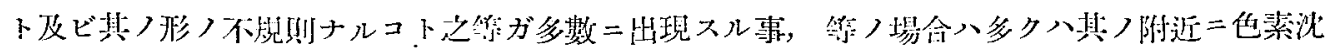

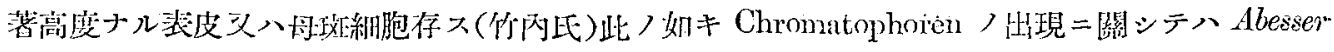

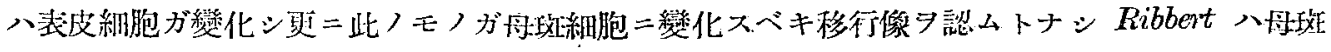

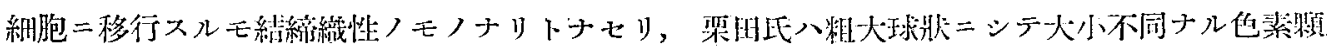

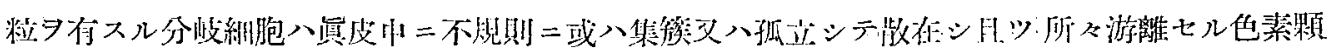




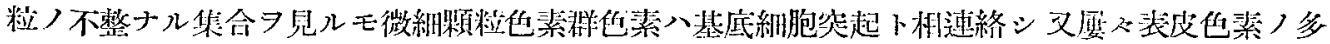
朞ニ一致セズト云へリ。

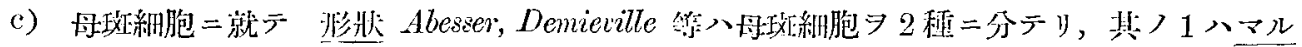

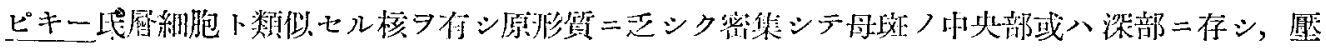

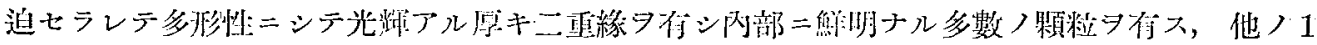

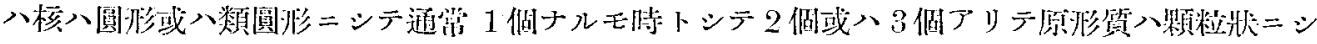

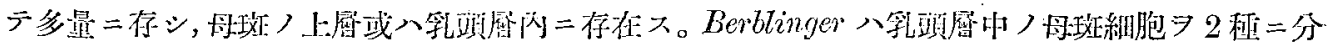

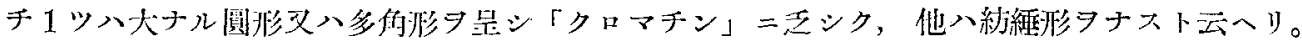

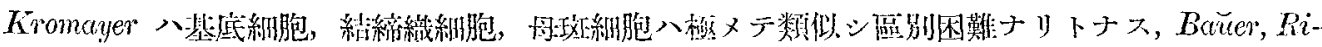

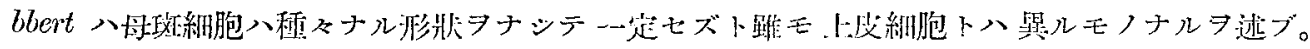

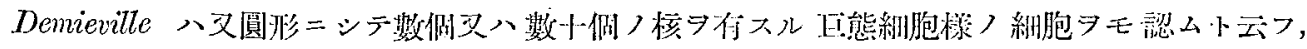

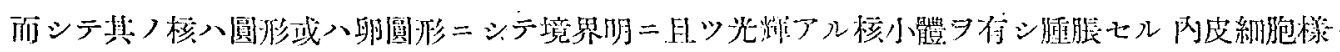

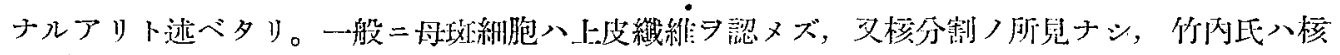

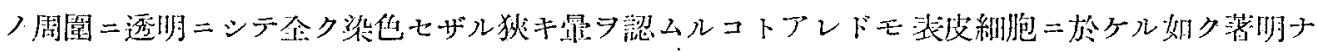

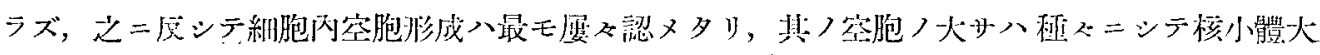

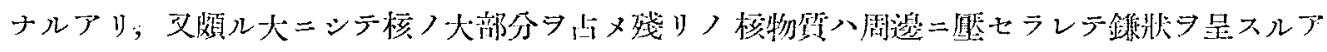

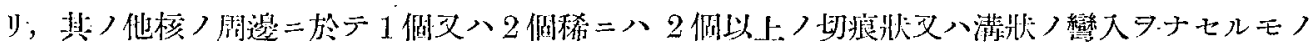

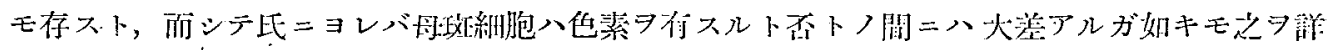

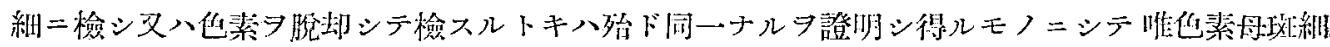

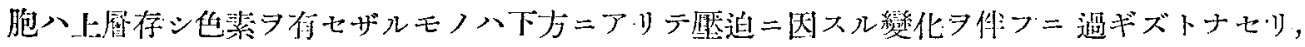

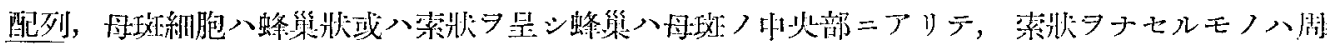

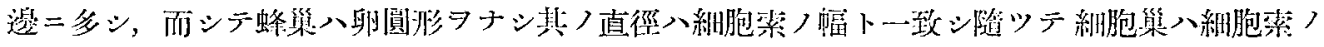

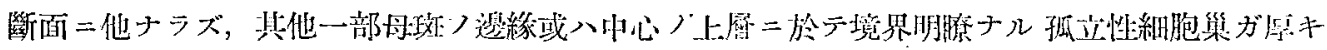

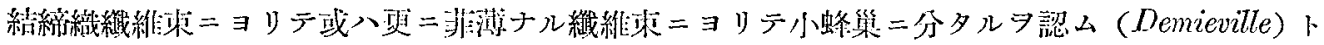

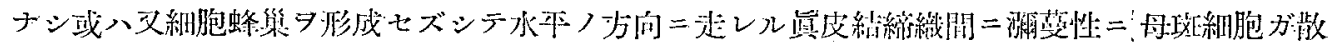

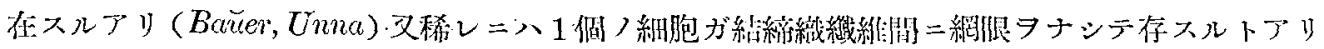

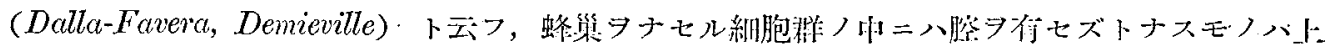

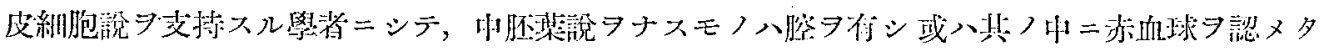

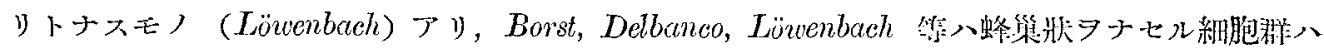
管腔冈 inbshy, Demieville，Green，Jadassohn，篎入內被絒胞八見シレザルモ管壁习認ムトナス，Borst

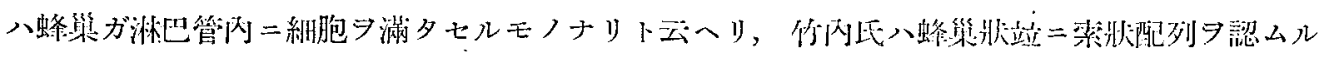

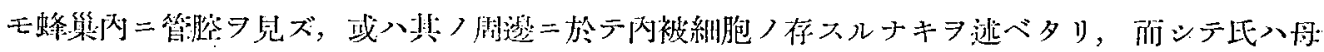




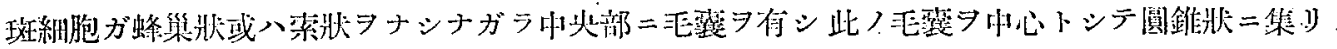

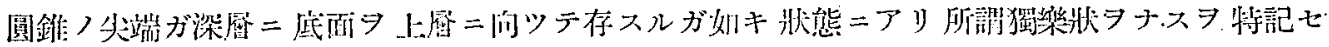
リ。

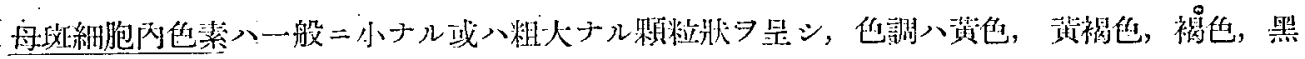

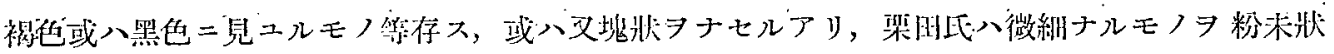

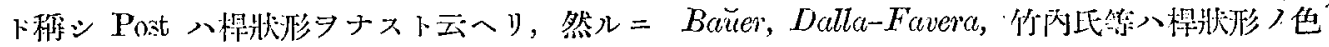

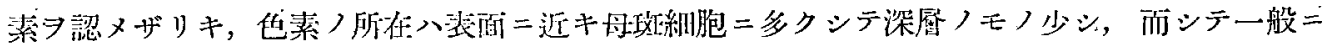

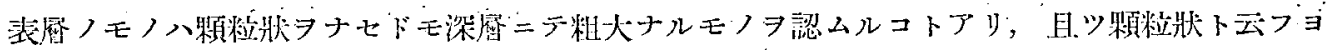

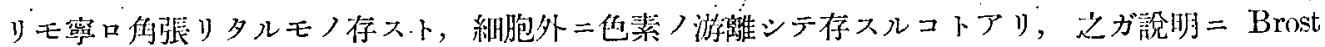

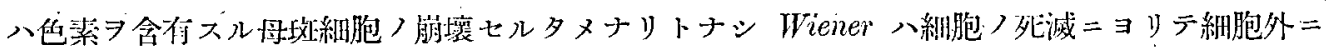

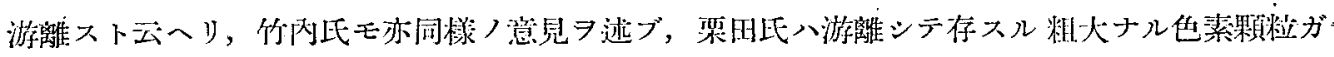

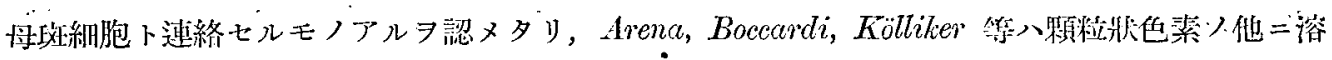

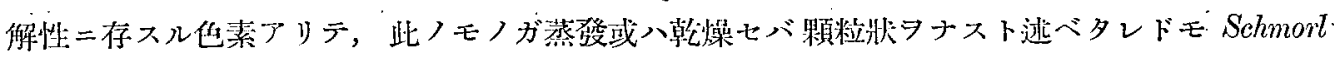

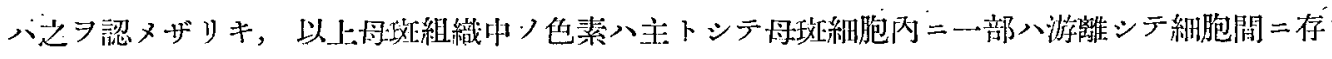

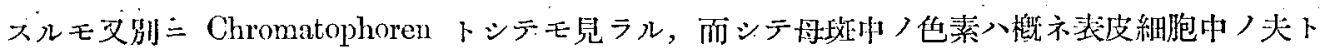

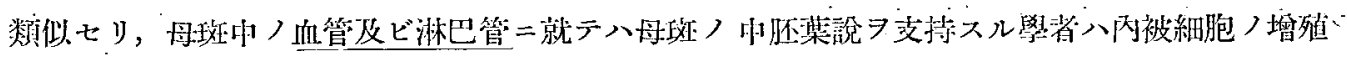

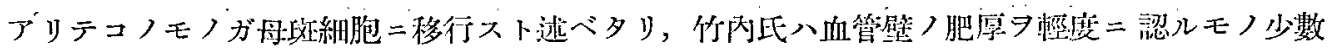

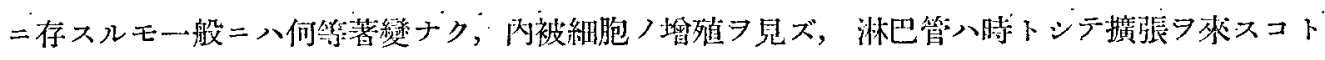

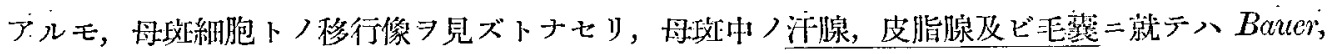

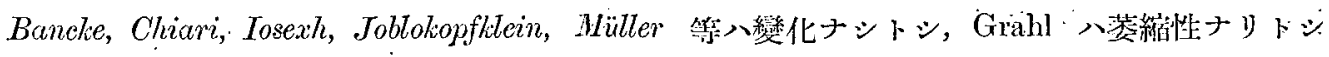
Demieville 八汗腺排洲管〉擴张ヨ認ムルコトアリトシ Dalla-Favera, Unina 等八汗腚或八皮

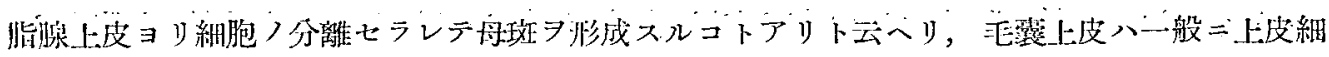

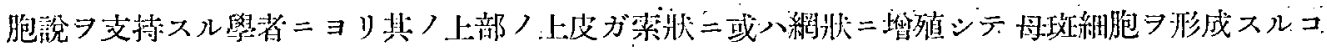

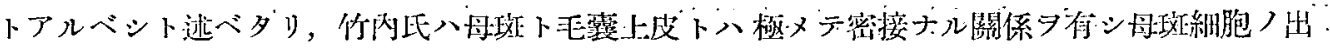

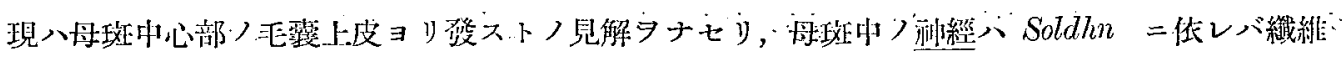

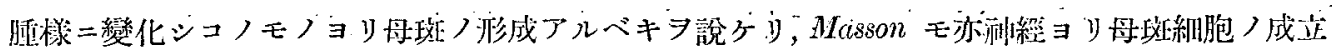

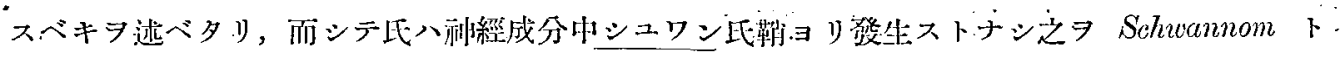

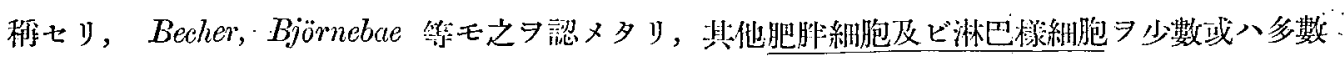

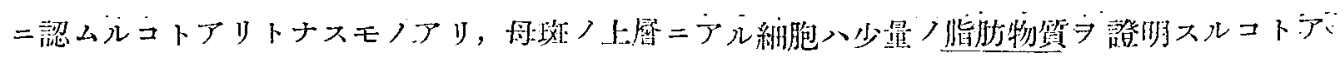
ルモ深層二於テハ之フ直ズト云つ。

第 4 章、研究例所見

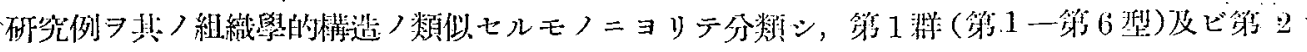

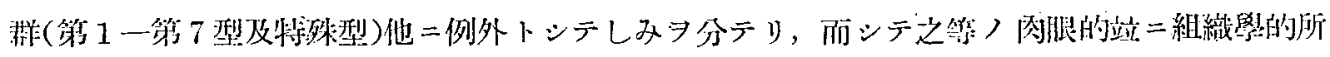


肉腿的所 見

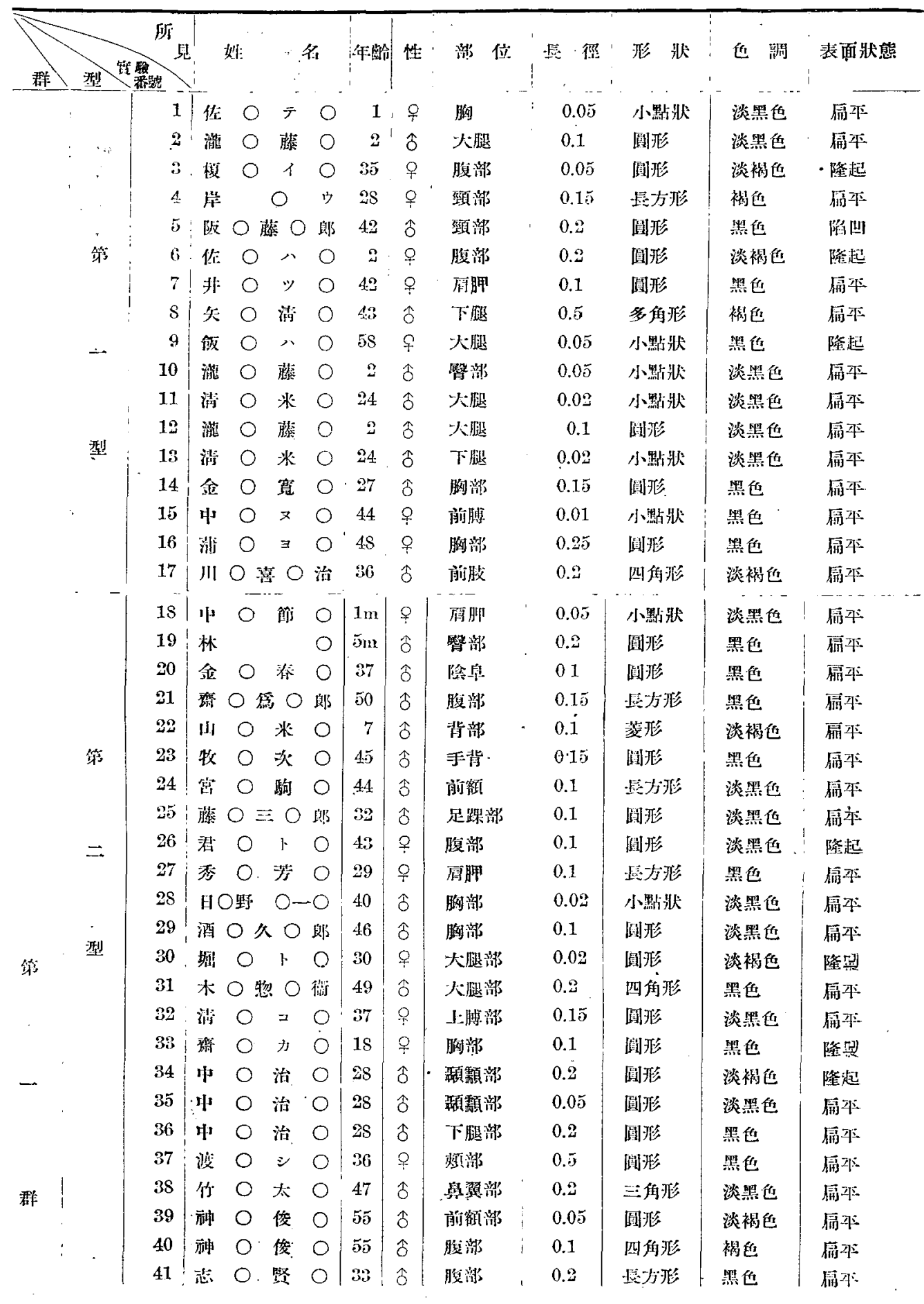




\begin{tabular}{|c|c|c|c|c|c|c|c|c|c|c|}
\hline 42 & 治 & 0 & 80 & 今 & 鼾翼部 & & 0.15 & 展方兆 & 褐色 & 消平 \\
\hline 43 & 治 & 0 & 30 & $\delta$ & 䁰部 & & 0.15 & 棏狀 & 淡黑色 & 滔凹 \\
\hline 44 & 大○淞 & $0:$ & 53 & $\delta$ & 大腿部 & & 0.15 & 唇方形 & 淡黑色 & 陷四 \\
\hline 45 & 藤 $\bigcirc$ 策 $\bigcirc$ & 咘！ & 20 & $\hat{o}$ & 胸部 & & 0.8 & 圆形 & 黑色 & 扇本 \\
\hline 46 & 佐 $\bigcirc \%$ & 0 & 2 & P & 前腓 & & 0.3 & 阅形 & 黑色 & 扁本 \\
\hline 47 & $0 \%$ & 0 & 49 & P & 上膊 & & 0.15 & 务筝形 & 黑色 & 澼本 \\
\hline 48 & ○伀 & 0 & 89 & $\hat{o}$ & 前脽 & & $0.0 \overrightarrow{5}$ & 小點狀 & 襡色 & 噼平 \\
\hline 49 & ○佐 & 0 & 29 & $\hat{o}$ & 前膊 & & 0.05 & 厓方形 & 骙黑色 & 扁本 \\
\hline 50 & ○任 & 0 & 29 & $\$$ & 㴊膊 & & 0.2 & 區形 & 淡褐色. & 隆起 \\
\hline 51 & ○利 & 0 & 33 & $\hat{\delta}$ & 鼠踩澶 & & 0.1 & 紡鍵班 & 褐色 & 滆平 \\
\hline 52 & 烃 0 平 0 & 毁 & 44 & ? & 足踝部 & ' & 0.01 & 回形 & 黑伯 & 扁平 \\
\hline 53 & 中 $\bigcirc$ 知 $\bigcirc$ & 7 & 19 & 욱 & 大避蔀 & & 0.05 & 压方形 & 淡黑色 & 陷䛛 \\
\hline 54 & 湾 $0 \equiv$ & 0 & 30 & $\hat{\delta}$ & 顴骬部 & & 0.15 & 国形 & 黑色 & 扁本 \\
\hline 55 & 新 $\bigcirc$ 狝 0 & 蚛 & 59 & $\hat{\delta}$ & 足背部 & & 0.3 & U形 & 淡黑色 & 确平 \\
\hline 56 & 軨 0 カ & O & 47 & 우 & 下腿暗 & & 0.1 & 三觕形 & 褐色 & 扁斥 \\
\hline 57 & $0 \bar{\tau}$ & 0 & 46 & 令 & 胸部 & & 0.15 & 三角形 & 㫮色 & 陷口 \\
\hline 58 & ○虎 & 0 & 45 & 9 & 鼠蹊部 & & 0.15 & 三角形 & 褐色 & 槅斥 \\
\hline 59 & ○ 五. & 0 & 25 & $\hat{o}$ & 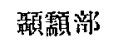 & & 1.6 & 圓形 & 淡黑色 & 扁斥 \\
\hline 60 & $0^{:}$策 & 0 & 45 & $\delta$ & 胸部 & & 0.3 & 医方形 & 淡黑色 & 扁平 \\
\hline 61 & $0 F$ & ッ & 46 & P & 胸筂 & . & 0.15 & 三角形 & 淡黑色 & 属平 \\
\hline 62 & 0 & 0 & 50 & 웅 & 粗部 & & 0.15 & 紡鉳狀 & 淡黑色 & 扁平 \\
\hline 68 & 竍 ○ッ & 0 & 30 & 우 & 腹部 & & 0.3 & 温形 & 黑色 & 扁平 \\
\hline 64 & 江 $\bigcirc$ 裙 $O$ & 郳 & 23 & $\hat{o}$ & 臍蔀 & & 0.15 & 三仵无 & 整色 & 扁平 \\
\hline 65 & 本 $\bigcirc$ 知 & 0 & 59 & $\hat{\beta}$ & 火鄉部 & & 0.25 & 棈圆形 & 淡黑色 & 陷凹 \\
\hline 66 & O宗 & 0 & 52 & $\hat{\jmath}$ & 胸部 & & 0.1 & 圆形 & 淡黑色 & 隆起 \\
\hline 67 & 荘 ○幾 $\bigcirc$ & 郎 & 47 & $\hat{\delta}$ & 上膊 & & 0.05 & 溇形 & 淡褐色 & 庇平 \\
\hline 68 & 霂 ○ * * & 吉 & 24 & 昘 & 胸部 & & 0.2 & [趹形 & 淡黑色 & 扁平 \\
\hline 69 & $0 \equiv$ & 0 & 45 & $\hat{0}$ & 除表 & & 0.05 & 三角形 & 淡黑第 & 病平 \\
\hline 70 & 0 & 0 & 7 & $\hat{0}$ & 智部 & & 0.05 & 圓形 & 淡㫮色 & 疤平 \\
\hline 71 & 0 & $O$ & 41 & $9^{\circ}$ & 腹蔀 & & 0.05 & 圓形 & 淡黑色 & 徧本 \\
\hline 72 & $\bigcirc$ & 0 & 37 & 守 & 陰䥺 & & 0.2 & 長方形 & 淡褐色 & 隆起 \\
\hline 73 & 0 & 0 & 37 & $\uparrow$ & 磨部 & & 0.05 & 圆形 & 紫色 & 隆起 \\
\hline 74 & $\bigcirc$ 浦 & $\bigcirc$ & 58 & $\hat{\delta}$ & 胸潡 & & 0.01 & [司]形 & 㫮色 & 秱尔 \\
\hline 75 & 延 ○虎 & 0 & 23 & 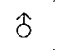 & 胸部 & & 0.15 & 小點狀 & 黑色 & 扁巫 \\
\hline 76 & O：虎 & 0 & 23 & s: & 胸暗 & & 0.08 & 棈圆形 & 褐色 & 疤平 \\
\hline 77 & 筫 & 覺 & 61 & 今 & 胸社 & & 0.05 & 圆形 & 淡黑色 & 閏平 \\
\hline 78 & 櫻 & 覺 & 61 & $\hat{\delta}$ & 胸部 & & 0.1 & 長方形 & 淡黑色 & 咞本 \\
\hline 79 & 小 $\mathrm{O}$ & 0 & 45 & P & 鼠蹊部 & & 0.1 & 四角形 & 淡裀色 & 隆起 \\
\hline $80:$ & 內 & 0 & 41 & $q^{\prime \prime}$ & 胸部‧ & & 0.1 & 圆形 & 黑色 & 滆本 \\
\hline $81 !$ & H $O \cdot \nabla$ & 0 & 45 & $9:$ & 㥛䣘 & & 0.05 & 圆形 & 黑色 & 澼平 \\
\hline 82 & 木 $\bigcirc$ 物 $\bigcirc$ & 郎 & 49 & $\hat{\circ}$ & 腹部 & & 0.1 & 圆形 & 黑色 & 斾本 \\
\hline 83 & 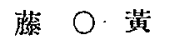 & 0 & 22 & $\hat{\delta}$ & 大腿被 & & 0.2 & 自形 & 淡黑色 & 隆起 \\
\hline 84 & $0+$ & 0 & 45 & 웅 & 背初 & & 0.15 & 多解形 & 黑色 & 扁平 \\
\hline 85 & $0 \cdot x$ & $0^{\prime}$ & 37 & 우 & 胸蔀 & & 0.2 & 国形 & 黑色 & 扇本 \\
\hline 86 & 無 & 0 & 43 & & 䫫部 & & 0.05 & 圆形 & 黑色 & 隆起 (乳頭) \\
\hline 87 & 金 $0^{\circ}$ 静 & 0 & 35 & 우 & 胸激 & & 0.15 & 回形 & 淡黑色 & 扇平 \\
\hline
\end{tabular}




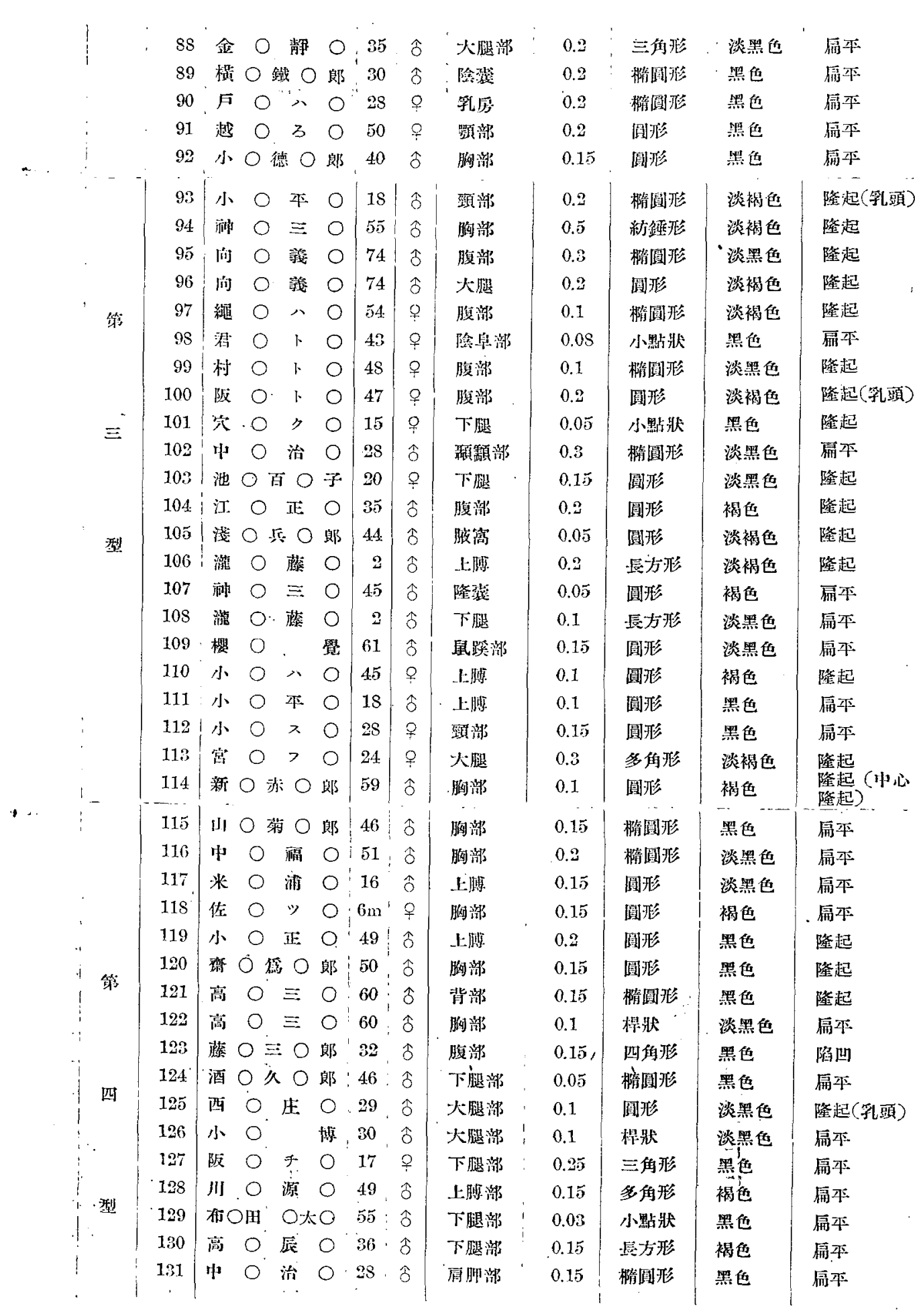




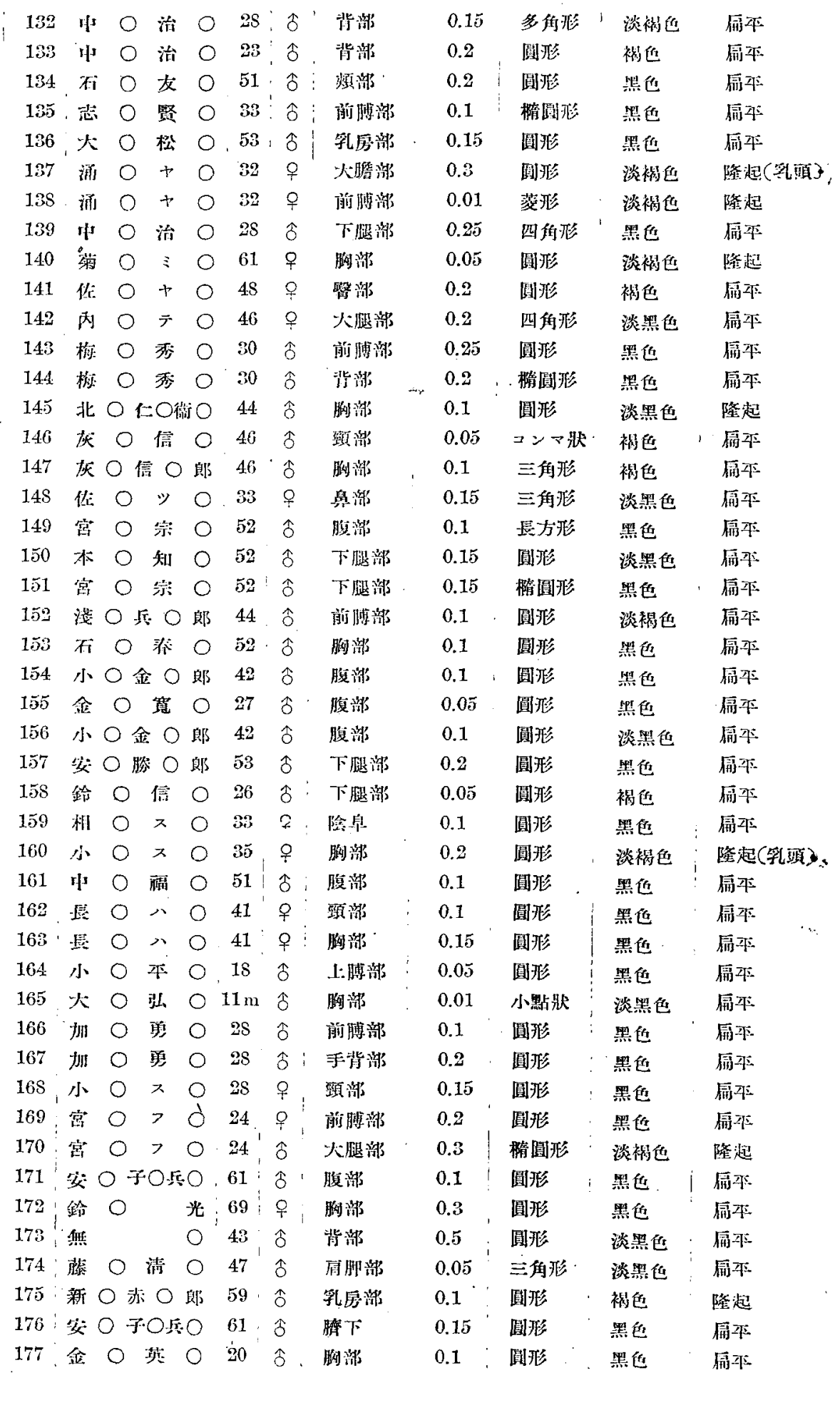




\begin{tabular}{|c|c|c|c|c|c|c|c|c|c|c|c|}
\hline & $17 \mathrm{~S}$ & 內 & ○福 & 0 & 18 & $\hat{\delta}$ & 背激 & 0.2 & 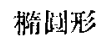 & 哭色 & 㕃平 \\
\hline & 179 & 雀 & 07 & 0 & 29 & p & 腈洮 & 0.15 & 表方形 & 器出 & 鬲本 \\
\hline & 180 & 中 & $0 \neq$ & 0 & 49 & q & 翡波 & 0.5 & [间]形 & 淡黑佔 & 隆起（乳頭） \\
\hline & 181 & 鹤 & $\bigcirc$ 和 & 0 & 32 & $\hat{\delta}$ & 腹漟 & 0.4 & 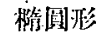 & 㫮色 & 扁本 \\
\hline & 182 & F & N & 0 & 28 & $q$ & 下腿激 & 0.1 & 小點狀 & 㫮色 & 鉴起 \\
\hline & 183 & 湤 & 清 & 0 & 39 & 尔 & 腹消 & 0.3 & 情形 & 䶂色 & 廨平 \\
\hline & 184 & 鈴 & 01 & 0 & 36 & ? & 啲漟 & 0.1 & 阊形 & 㫮出 & 雇本 \\
\hline & 185 & 鈴 & $0^{\prime \prime \prime} 1$ & 0 & 36 & $\varphi$ & 胸洓 & 0.2 & 战形 & 淡黑色 & 隆起 \\
\hline & 186 & 鈴 & 01 & $\mathrm{O}$ & 36 & ? & 乳店部 & 0.2 & 三伿形 & 淡黑色 & 隆起 \\
\hline & 187 & 饭 & $\bigcirc$ 高 & 0 & 21 & 令 & 前煿彩 & 0.1 & 国形 & 黙色 & 扁永 \\
\hline & $18 S$ & 领 & ○：高 & 0 & $\Sigma 1$ & $\delta$ & 火四邀 & 0.15 & 畾形 & 哇色 & 厚平 \\
\hline & 189 & 份 & $O$ 高 & 0 & 28 & $\delta$ & 䐘钗 & 0.3 & 棈㴻形 & 墨色 & 隆起 \\
\hline & 190 & 川 & $\bigcirc$ 喜 $\bigcirc$ & 治 & 30 & $\hat{\delta}$ & 顽蔀 & 0.15 & 新鍎杉 & 䙓色 & 隆起 \\
\hline & 191 & 中 & $0 \quad \forall$ & 0 & 25 & 9 & 脽澈 & 0.3 & 龧方形 & 㫮色 & 厚平 \\
\hline & 192 & 久 & 0 & 0 & 36 & $?$ & 有肺啝 & 0.2 & 四形 & 襍色 & 㕄平 \\
\hline & 193 & III & $\bigcirc$ 落 $\bigcirc$ & 郎 & 46 & $\hat{0}$ & 腹激 & 0.3 & 敉側形 & 黑巴 & 示尔 \\
\hline & 194 & 莍 & ○茫 & 0 & 47 & $\delta$ & 士肢嘫 & 0.1 & 间形 & 哭色 & 槅本 \\
\hline & 195 & 村 & $0 \mathrm{r}$ & 0 & 22 & 우 & 背浓 & 0.2 & 圆形 & 㫮色 & 槅弪 \\
\hline & 196 & * & ○ 浦 & 0 & 58 & $\hat{\delta}$ & 下跭新 & 0.1 & 䟝死 & 熙色 & 槅本 \\
\hline 第 & 197 & 釗 & $O$ s & 0 & 33 & 움 & 胸激 & 0.1 .5 & 澎珠 & 黑色 & 隆起 \\
\hline & 198 & & $O \quad t$ & 0 & 38 & 우 & 下腿部 & 0.1 & 四角形 & 淡眥色 & 㕄本 \\
\hline & 199 & & $\bigcirc \quad \exists$ & 0 & 10 & 우 & I:膊济 & 0.1 & 圆形 & 黑色 & 痛平 \\
\hline & 200 & 小 & ○秀 & 0 & 38 & $\hat{\delta}$ & 臍蔀 & 0.2 & 圆形 & 衸色 & 槅平 \\
\hline & 201 & 清 & ○米 & 0 & 24 & $\hat{\delta}$ & ?胸涪 & 0.2 & 圆形 & 黑色 & 原本 \\
\hline 正. & 202 & w & $\bigcirc$ 盛 & 0 & 19 & $\hat{\delta}$ & 上膊部 & 0.1 & 圓形 & 舆任 & 槅平 \\
\hline & 203 & 金 & ○ 倠 & 0 & 37 & $\hat{\delta}$ & 頙㥒 & 0.1 & 闹 & 黑色 & 槅平 \\
\hline & 204 & 水 & O 正 & $\mathrm{O}$ & 49 & $\delta$ & 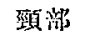 & 0.2 & 紡鉽形 & 黑色 & 㾔平 \\
\hline & 205 & 忪 & 0 중 & 郎 & 47 & $\delta$ & 原脚部 & 0.1 & 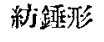 & 淡哭色 & 疤本 \\
\hline 犁 & 206 & 松 & 0 平 0 & 郎 & 47 & $\delta$ & 胸洲 & 0.05 & 圓形 & 黑色 & 扁平 \\
\hline & 207 & 䓋 & $\bigcirc$ 膯 $\bigcirc$ & 郎 & 53 & $\hat{\delta}$ & 頸暗 & 0.8 & 卧方形 & 黑色 & 丽平 \\
\hline & 208 & 发 & $O-\mathrm{J} * \mathrm{O}$ & $\mathrm{EO}$ & 61 & $\hat{\delta}$ & 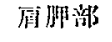 & 0.1 & 圓㝴 & 黑色 & 暦平 \\
\hline & 209 & 蜜 & ○仿O & 郎 & 50 & $\hat{0}$ & 獥暗 & 0.15 & 圆现 & 黑色 & 楅平 \\
\hline & 210 & 槛 & $O$ 鐵 0 & 郳 & 30 & $\hat{\delta}$ & 有胛部 & 0.15 & 圆形 & 黑色 & 陷山 \\
\hline & 211 & † & $0 x$ & $\mathrm{O}$ & 44 & 움 & I:煿被 & 0.1 & 傊形 & 褀色 & 陷凹 \\
\hline & 212 & 澈 & ○ 藤 & $\mathrm{O}$ & 60 & $\hat{\delta}$ & 胕涪 & $0.0 \mathrm{~s}$ & 四任形 & 黑色 & 扇平 \\
\hline & 213 & 者 & $0^{\prime} r$ & $\mathrm{O}$ & 46 & 우 & 䫓蔀 & 0.3 & [湜]犻 & 淡裼色 & 䧑起 (乳頭) \\
\hline & 214 & 小 & 0 金 0 & 郎 & 42 & $\hat{\delta}$ & 胸蔀 & 0.1 & 䦌珠 & 䱊色 & 屚平 \\
\hline & 215 & 舳 & & 0 & 不明 & & & 0.2 & 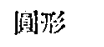 & 黑化 & 檽平 \\
\hline & 216 & 無 & & 0 & 不明 & & & 0.4 & 琴力形 & 褟色 & 隆起 (学嘼) \\
\hline & 217 & & ○. 利 & 0 & 30 & 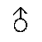 & 鼠蹊棌 & 0.1 & 绢形 & 裸色 & 㕄本 \\
\hline & 218 & 松 & 0 & 甬 & 27 & $\hat{\delta}$ & 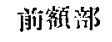 & 0.7 & 酷殁 & 裮色 & 隆起 \\
\hline & 219 & 五. & O. 咸 $\mathrm{O}$ & 郎 & 21 & $\delta$ & “下゙腿被 & 0.1 & 四觕形 & 黙色 & 厚平 \\
\hline & 220 & is & $0 \equiv 0$ & $\Xi$ & 52 & $\hat{0}$ & 下眼瞼 & 0.1 & 咱 & 墨黑色 & 屚平（中心 \\
\hline & 221 & & ○篓 & 0 & 74 & $\hat{\delta}$ & 久腿部 & 0.3 & 河犻 & 淡黑色 & 隆起 \\
\hline & 222 & & 01 & 0 & 48 & 운 & 大股济 & 0.1 & 消抢 & 黑色 & 螎不 \\
\hline
\end{tabular}




\begin{tabular}{|c|c|c|c|c|c|c|c|c|c|c|}
\hline 223 & 繩 & 0 & 0 & 54 & 우 & 胸激 & 0.2 & 圓形 & 黑色 & 惼平 \\
\hline 224 & 石 & $0^{\circ}$ & 0 & $2 S$ & $\hat{\delta}$ & 腹部 & 0.1 & 小點狀 & 淡埋色 & 隔平 \\
\hline 225 & 不 & $0 \pi$ & 0 & 28 & $\hat{\delta}$ & 菲部 & 0.1 . & 紋鈛形 & 淡黑色 & 隆起 \\
\hline 226 & 村 & 0 & 0 & 48 & 오 & 下腿部 & 0.1 & 圓形 & 淡黑色 & 滆平 \\
\hline 227 & 秀 & O 莎 & 0 & 89 & $\hat{o}$ & 胸部 & 0.05 & 小點狀 & 淡鲍色 & 肩本 \\
\hline 228 & $B$ & ○ 野O- & & 40 & $\hat{o}$ & 脣脚保 & 0.2 & 長方形 & 黑色 & 的平 \\
\hline 829 & 上 & 0 & 0 & 16 & $\hat{o}$ & 胸涪 & 0.1 & 四角北 & 黑色 & 仿斗 \\
\hline 230 & 木 & $\bigcirc$ 制 $\bigcirc$ & 郎 & 49 & $\hat{o}$ & 冽粈 & 0.1 & 提狀 & 裼色 & 痛本 \\
\hline 281 & III & 0 & 0 & 51 & 우 & 胸幥 & 0.2 & 圓形 & 黑色 & 病平 \\
\hline 232 & 䑐 & 0 & 景 & 44 & $\hat{o}$ & 陸激 & 0.5 & 圓形 & 黑色 & 㵝本 \\
\hline 238 & 㭗 & 0 & 帠 & 44 & $\hat{\delta}$ & 下服帮 & 0.3 & 莀方形 & 黑色 & 瘘本 \\
\hline 234 & 西 & ○生 & 0 & 89 & 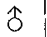 & 背部 & 0.2 & 圓形 & 淡黑色 & 原平 \\
\hline 235 & 軨 & 0 & 0 & 45 & 우 & 大㜆部 & 0.2 & 辰方形 & 褐色 & \\
\hline 236 & 池 & 0 . & 慶 & 42 & $\hat{\partial}$ & 前膊被 & 0.2 & 線状 & 黑色 & 痛年 \\
\hline 287 & 川 & ○ 源 & 0 & 49 & $\hat{b}$ & 火能蔀 & 0.3 & 医方形 & 淡黑色 & 届平 \\
\hline 238 & $中$ & 0 & 0 & 28 & $\hat{o}$ & 大腿部 & 0.2 & 圆形 & 黑色 & 扁平 \\
\hline 239 & $\boldsymbol{p s}$ & ○ 治 & 0 & 28 & $\hat{\delta}$ & 下腿暗 & 0.2 & 三解形 & 黙色 & 俩平 \\
\hline 240 & 小 & 0 & 0 & 27 & $\hat{\delta}$ & 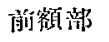 & 0.1 & 圆形 & 墨他 & 屌平 \\
\hline $24: 1$ & 小 & 0 & 0 & 27 & $\hat{\delta}$ & 胸蔀 & 0.35 & 条解形 & 黑色 & 扁斥 \\
\hline 242 & 窎 & 然 & 0 & 33 & $\hat{\sigma}$ & 胸激 & 0.2 & 長方形 & 䶂色 & 隆起 \\
\hline 243 & 卅 & $0=0$ & ウ & 47 & 우 & 前膊辣 & 0.3 & 多角形 & 䶂色 & 陷凹 \\
\hline 244 & 大 & ○ 松 & 0. & 53 & $\hat{0}$ & 角行膊部 & 0.2 & 長方兆 & 淡褐色 & 隆起 \\
\hline 245 & $J_{F}$ & $\mathrm{O}$ & ウ & 28 & Q & 胸辣 & 0.75 & 三角现 & 哇任 & 藊本 \\
\hline 246 & 非 & 0 & 0 & 48 & 우 & 层别激 & 0.2 & 四解源 & 品色 & 槅來 \\
\hline 247 & $\pi j^{\circ}$ & 0 & 0 & 38 & 우 & 胸部 & 0.2 & 四角形 & 茝色 & 隆起 \\
\hline $24 \mathrm{~S}$ & i|ji & $\mathrm{O}$ & 0 & 38 & 우 & 大盛部 & 0.15 & 圓形 & 褐色 & 隆起 \\
\hline 249 & 中 & ○ 治 & 0 & 28 & $\hat{o}$ & 背漓 & 0.2 & 四角形 & 裼色 & 㕃本 \\
\hline 250 & 關 & $\odot^{\prime} r$ & .0 & 34 & 웅 & 腹部 & 0.2 & 四形 & 淡黑色 & 槅东 \\
\hline 251 & 中 & $\bigcirc$ 知 & 0 & 18 & 우 & 足嚓新 & 0.15 & 辰为形 & 嘿色 & 屌本 \\
\hline 252 & 鈴 & $0 x$ & 0 & 9 & 우 & 购部 & 0.1 & 圆形 & 淡㫮色 & 摒斥 \\
\hline 253 & 下 & ○ F & 郎 & 29 & $\hat{\delta}$ & 擅膊部 & 0.15 & 㵋形 & 淡黑色 & 屚本 \\
\hline 254 & 下 & 0 F 0 & 郎 & 29 & $\hat{\delta}$ & 胸部 & 0.2 & 稀圆形 & 黑色 & 㕄平 \\
\hline 255 & 使 & + & 0 & 48 & 우 & 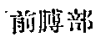 & 0.4 & 長方北 & 黑化 & 槅本 \\
\hline 256 & 落 & ○虎 & 0 & 45 & $\hat{o}$ & 手背部 & 0.15 & 圓环。 & 褐色 & 陷凹 \\
\hline 257 & 洛 & O: 虎 & 0 & 45 & $\hat{o}$ & 下腿漷 & 0.03 & 小點狀 & 黑色 & 隆起 \\
\hline $2 \overline{8} 8$ & 內 & $0 \%$ & 0 & 46 & 웅 & 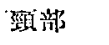 & 0.15 & 長方形 & 褐色 & 隆起 \\
\hline $259^{\circ}$ & & $0 \equiv$ & 0 & 15 & 운 & 大慥榊 & 0.2 & 浿形 & 黑色 & 隆起 \\
\hline 260 & 宫 & ○ 浔 & 0 & 45 & $\hat{\delta}$ & 腳蔀 & 0.25 & 圓形 & 黑色 & 扁平 \\
\hline 261 & 宮 & ○峩 & 0 & 45 & $\hat{\delta}$ & 乳房部 & 0.2 & 長方形 & 淡黑㶵 & 隆起 \\
\hline 262 & 北 & $O 1: 0 x$ & $=0$ & 44 & $\$$ & 上膊部 & 0.15 & 舆方形 & 黑色 & 雬华 \\
\hline 263 & 阪 & $\bigcirc$ 藤 $\bigcirc$ & 郎 & 42 & 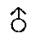 & 背部 & 0.3 & 㴘形 & 淡褐色 & 隆起 \\
\hline 264 & 中 & $0 \neq 0$ & 子 & 18 & 우 & 翦膊洮 & 0.3 & 長方形 & 淡㫮色 & 槅本 \\
\hline 265 & 灰 & $\bigcirc$ 信 $\bigcirc$ & 郎 & 46 & 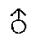 & 滕辣 & 0.15 & 三角形 & 褐色 & 厡起 \\
\hline 266 & 佊 & $O$ 金 0 & 郎 & 59 & $\pi$ & 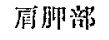 & 0.2 & 圆形 & 淡䙓色 & 隆起 \\
\hline 267 & 小 & 0 & 羿 & 30 & $\delta$ & 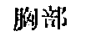 & 0.15 & 圓形 & 黑色 & 㕄平 \\
\hline 268 & 穴 & $0: y$ & 0 & 15 & 9 & 莖激 & 0.03 & 圓形 & 黑他 & 隆起 \\
\hline
\end{tabular}




\begin{tabular}{|c|c|c|c|c|c|c|c|c|c|}
\hline & 269 & 北 ○ 仁工門 & 44 & $\hat{\delta}$ & 不脚漟 & 0.15 & 阅形 & 黑色 & 隆起 \\
\hline & 270 & 江 $\bigcirc$ 稫 $\bigcirc$ 毁 & 23 & $\hat{0}$ & 胸部 & 0.15 & 圆形 & 黑色 & 徧平 \\
\hline & 271 & 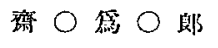 & 50 & $\hat{o}$ & 大腿部 & 0.3 & 棱圆形 & 黑色 & 扁本 \\
\hline & 272 & 渵 0 * 0 & 24 & $\hat{0}$ & 腹部 & 0.05 & 圓形 & 褐色 & 屌本 \\
\hline & 273 & 小 $\bigcirc$ 金 $\bigcirc$ 歁 & 42 & $\hat{o}$ & 鼻蔀 & 0.1 & 圓形 & 黑色 & 屜本 \\
\hline & 274 & 山 $O \neq 0$ & 41 & 운 & 厭胛部 & 0.3 & 長方形 & 黑色 & 扁本 \\
\hline & 275 & 要 $\bigcirc$ 虎 0 & 28 & $\hat{0}$ & 頚部 & 0.1 & 圓北 & 黑色 & 扁平 \\
\hline & 276 & 鍮 $O$ 信 $O$ & 26 & $\hat{o}$ & 下腿部 & 0.2 & 圓形 & 黑色 & 扁本 \\
\hline & 277 & 鉿 $\bigcirc$. 信 $\bigcirc$ & 26 & $\hat{\delta}$ & 下腿部 & 0.05 & 小點妝 & 褐色 & 扁平 \\
\hline & 278 & 藤 $\bigcirc$ 潜 $○$ & 47 & $\hat{o}$ & 成胛部 & 0.05 & 圆形 & 淡黑蚚 & 肁本 \\
\hline & 279 & 村 $\mathrm{O} \neq \mathrm{O}$ & 48 & 웅 & 局肺深 & 0.2 & 圆形 & 唒色 & 扇尔 \\
\hline & 280 & 竹 $0 \times 0$ & 29 & 우 & 股䆚 & 0.1 & 格圆形 & 淺黑色 & 隆起 \\
\hline & 281 & 弓 $\mathrm{O}$ 金 & 46 & $\$$ & 胸激 & 0.1 & 長方形 & 黑色 & 隆起 \\
\hline & 282 & 木○金 ○郎 & 59 & $\hat{o}$ & 腹部 & 0.6 & 回形 & 黑色 & $\begin{array}{l}\text { 扇尔 } \\
\text { 隆起) }\end{array}$ \\
\hline & 283 & 非 0 八 0 & 3 & 우 & 前膊暗 & 0.01 & 圓形 & 黑色 & 府平 \\
\hline & 284 & 川 $\bigcirc$ 韾 $\bigcirc$ 治 & 30 & $\hat{s}$ & 火腿部 & 0.1 & 線狀 & 黑色 & 扁斥 \\
\hline & 285 & 岩 $\bigcirc$. 義 $\bigcirc$ & 28 & $\hat{o}$ & 腹部 & 0.2 & 國形 & 㫮色 & 隆起 \\
\hline & 286 & 田 $0 .>0$ & 30 & 우 & 大腿部 & 0.15 & 圆形 & 淡黑色 & 扁平 \\
\hline & 287 & 田 $O>$ & 30 & 운 & 上櫵部 & 0.1 & 圓形 & 㫮色 & 屜本 \\
\hline & 288 & 吉 $\mathrm{O} \cdot \mathrm{r} O$ & 46 & 우 & 大腿部 & 0.05 & 小點狀 & 黑色 & 㳱平 \\
\hline & 289 & 無．名 & & & & 0.3 & 圓刓 & 黑色 & 隆起 \\
\hline 第 & .290 & 五 ○藏 ○郎 & 21 & $\hat{8}$ & 胸部 & 0.2 & 圆形 & 黑墨 & 厥斥 \\
\hline & 291 & 藤 $\bigcirc \equiv 0$ 郎 & 32 & $\$$ & 脷暗 & 0.2 & 圆形 & 黑色 & 扇本 \\
\hline & 292 & 繩 $\bigcirc$ 八 $\bigcirc$ & 54 & 운 & 层那涪 & 0.05 & 阔形 & 墨的 & 启本 \\
\hline & 293 & 石 0 . 才 & 28 & 腬 & 大越部 & 0.2 & 圆形 & 淡黑色 & 隆起 \\
\hline 六 & 294 & 君 O. & 43 & 우 & 胸溸 & 0.05 & 小點将 & 黑色 & 澼本 \\
\hline & 295 & 秀 $\bigcirc$ 芳. $\bigcirc$ & 29 & $\hat{0}$ & 率膊膊部 & 0.1 & 圆形 & 黙色: & 雇平 \\
\hline & 296 & 渡 0 卜 & 47 & 우 & 贫肺部 & 0.2 & 紛錘形 & 黑色. & 扁斥（中心 \\
\hline & 297 & 西 $\bigcirc$ 生 $O$ & 29 & $\hat{\delta}$ & 胸部 & 0.2 & 圆形 & 㫮色 & $\begin{array}{l}\text { 隆起) } \\
\text { 后本 }\end{array}$ \\
\hline 型 & 298 & 内 $\bigcirc$ ア & 8 & P & 前膊蔀 & 0.1 & 國形 & 淡黑色 & 届本 \\
\hline & 299 & 小 0 & 30 & $\hat{\delta}$ & 脺部 & 0.1 & 圆形 & 黑色 & 搹本 \\
\hline & 300 & 鈴 0 t & 45 & 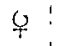 & 上膊部 & 0.05 & 圆形 & 黑色 & 扈本 \\
\hline & 301 & 解 0.1 & 34 & 옹 & 警初 & 0.2 & 圓形 & 褐色 & 屌本 \\
\hline & 302 & 高 0 . 辰 & 36 & $\hat{\delta}$ & 㷧部 & 0.2 & 阹圓形 & 黑色 & 陑平 \\
\hline . & 380 & 中 ○- 治 & 28 & 今 & 皟㛲部 & 0.05 & 小點狀 & 淡黑色 & 扁平 \\
\hline & 304 & 石 0 友 0 & 51 & 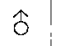 & 煩部 & 0.2 & 圆形 & 黑色 & 扁本 \\
\hline . & 305 & 石 $\bigcirc$ 犮 $\bigcirc$ & 51 & $\$$ & 胸部 & 0.3 & 長方形 & 黑色 & 厚平 \\
\hline & 306 & 脯 $\bigcirc$ 憲 $\bigcirc$ 䬦 & 45 & 㑒 & 胸激 & 0.2 & 長方形 & 黑色 & 扁本 \\
\hline & 307 & 宮 $\bigcirc$ 孝 $\bigcirc$ & 33 & $\hat{\delta}$ & 原溮部 & 0.15 & 㥞形 & 黑绝 & 扁平 \\
\hline & 308 & 宮 O. 荸 $\mathrm{O}$ & 33 & $\hat{0}$ & 上溥蔀 & 0.2 & 多化形 & 黑色 & 螎本 \\
\hline$\therefore$ & 309. & 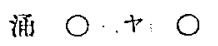 & 32 & 웃 & 獥部 & 0.01 & 桿状 - & 裀色 & 陷以 \\
\hline & 310 & 小 $\bigcirc$ 正 $O$ 郎 & 32 & $\hat{0}$ & 脺蔀 & 0.3 & 圓形 & 黑色 & 扁平 \\
\hline & 311 & 小 $\bigcirc$ 正 $\bigcirc$ 郎 & 32 & 余 & ·除翟 & 0.2 & 國形 & 黑色 & 搞平 \\
\hline$\because ?$ & 312 & 任 $0^{\circ}+\infty$ & 48 & 우 & 繁被 & 0.2 & 四觕形 & 淡黑色 & 瀜斥 \\
\hline$\therefore$ & 313 & 小 $\bigcirc$ 梀 0 . & 35 & 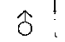 & 前额激 & 0.2 & 圓形 & 黑色 & 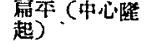 \\
\hline
\end{tabular}




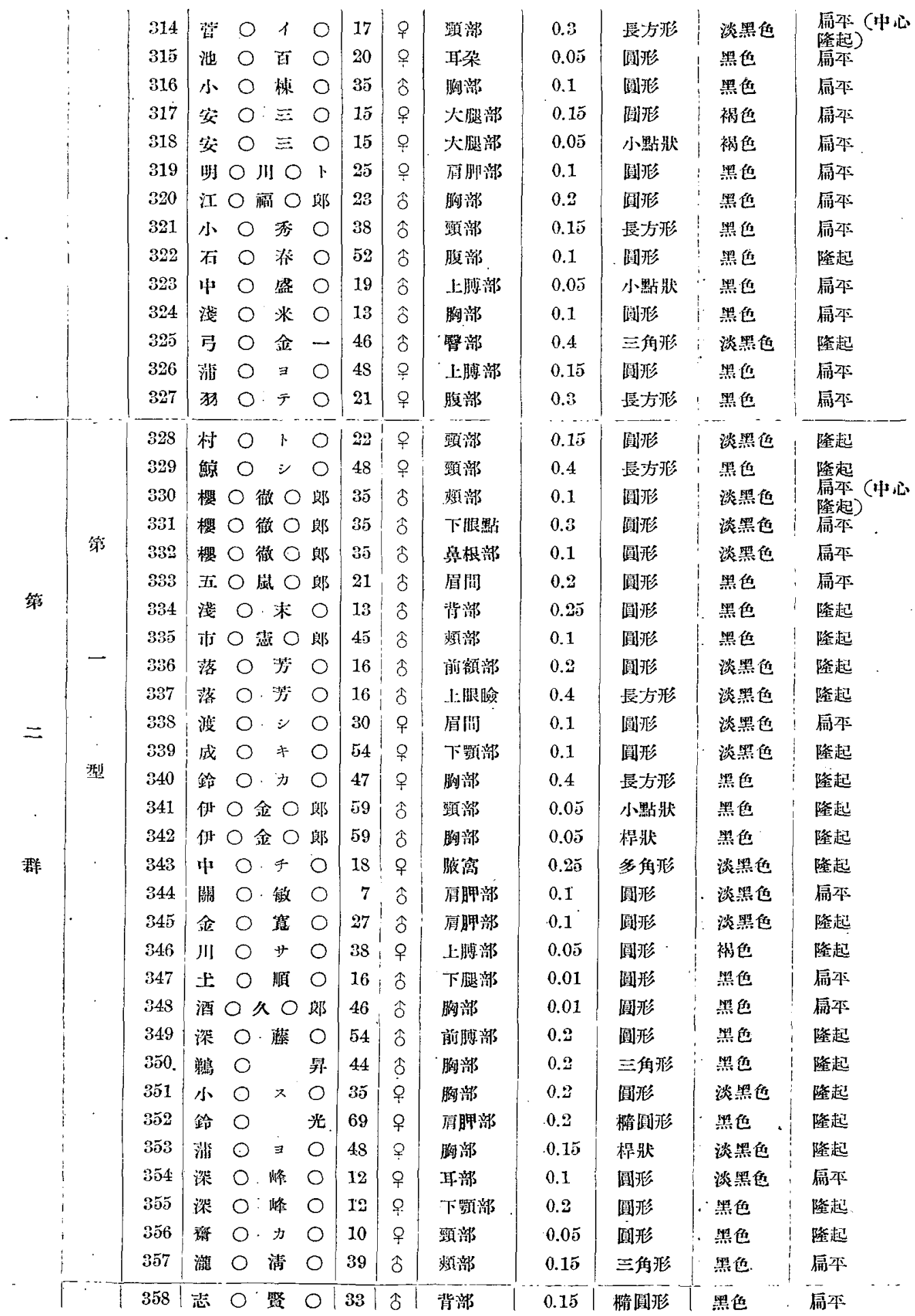




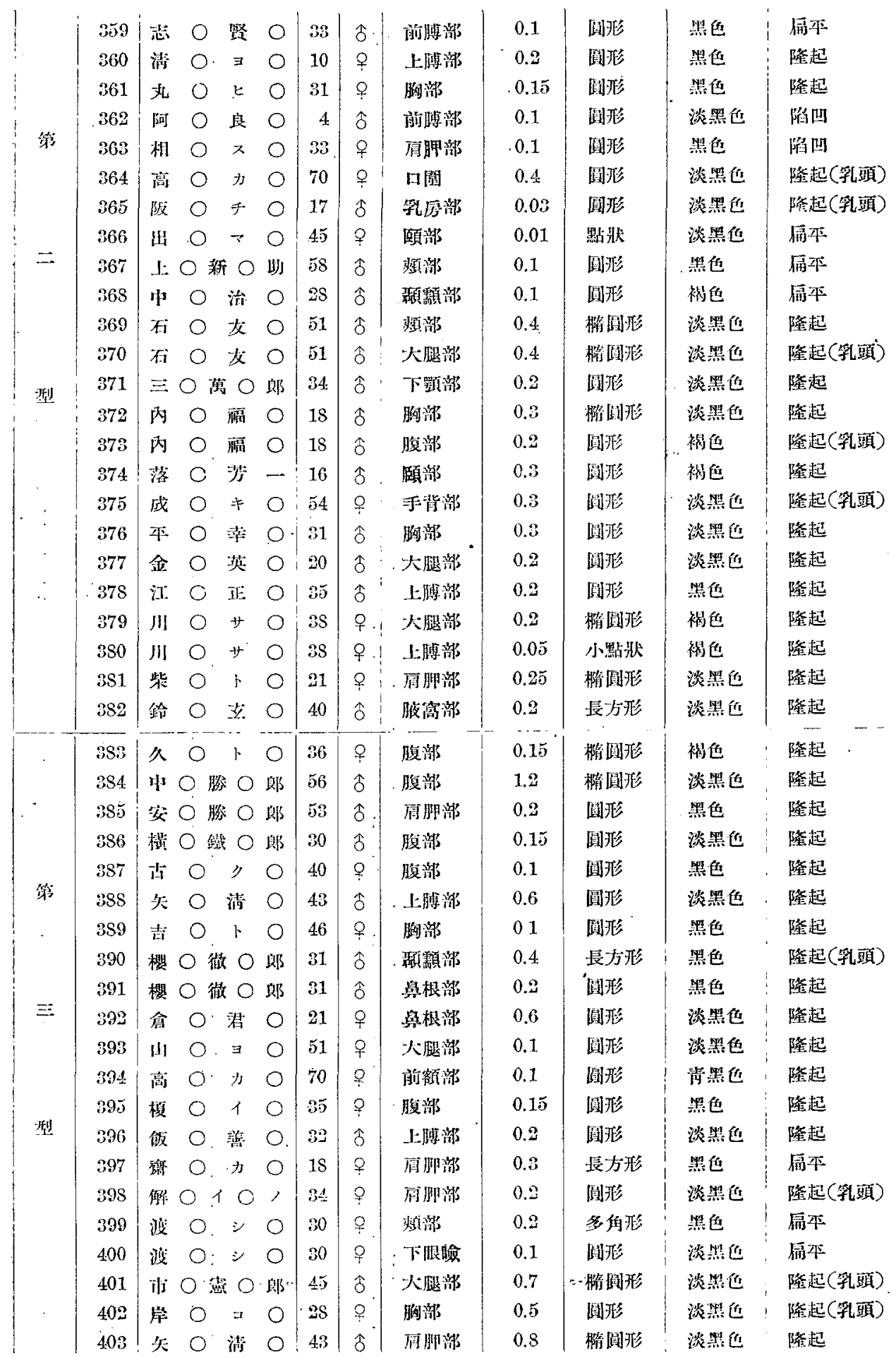




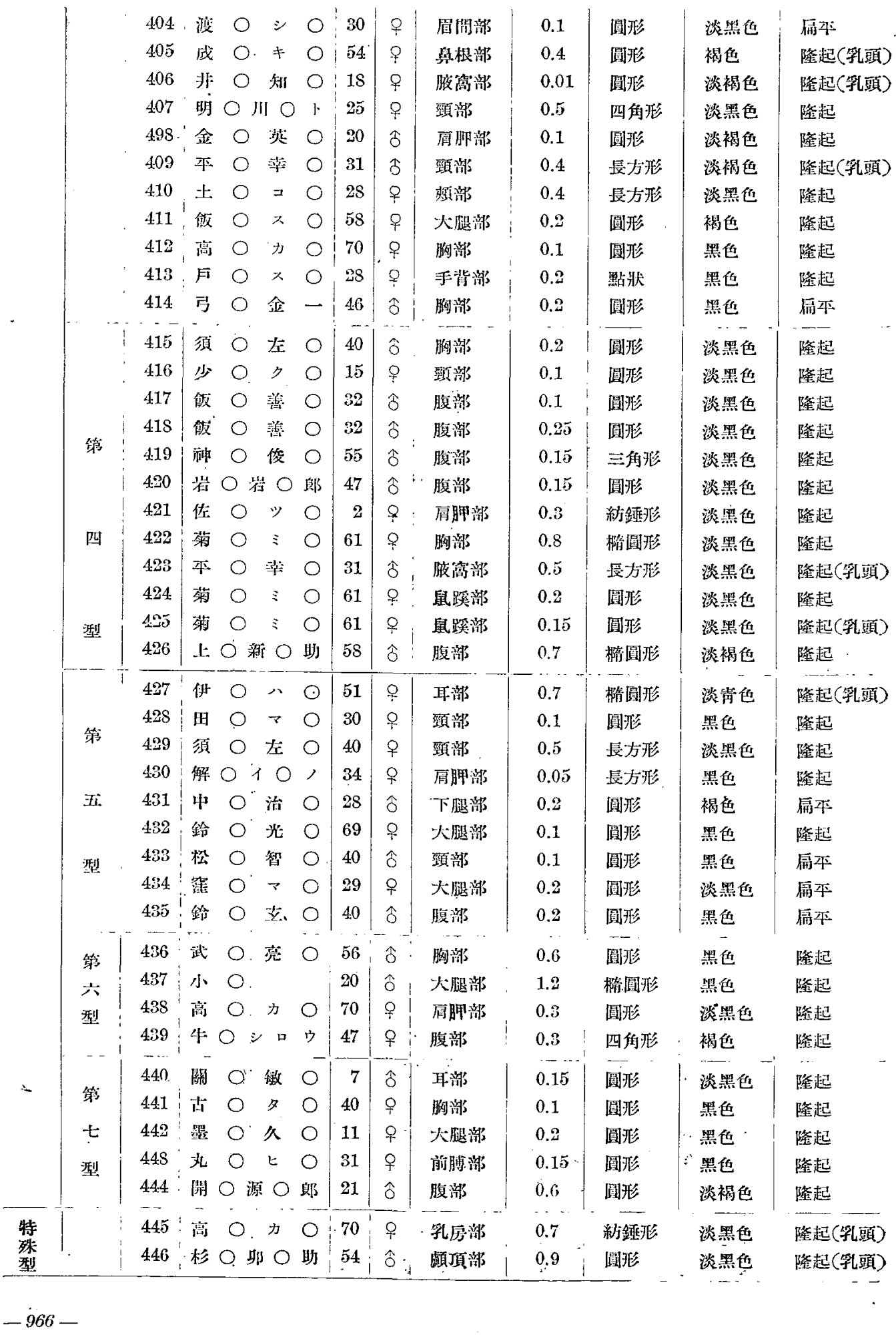




\begin{tabular}{|c|c|c|c|c|c|c|c|c|c|}
\hline \multirow[t]{2}{*}{ 例 } & 447 & 宾 ○ 駒 $\bigcirc$ & 44 & $\hat{0}$ & 前额 & 0.1 & 圓形 & 淡黑色 & 扁平 \\
\hline & 448 & 术 $\bigcirc$ 恚 $\bigcirc$ 郎 & 45 & $\hat{\delta}$ & 弦㛲 & 0.15 & 橔圆形 & 黑色 & 冨平 \\
\hline & 449 & 手 $O$ 李 $O$ & 31 & $\hat{\delta}$ & 火腿 & 0.25 & 圆形 & 淡褐色 & \\
\hline & 450 & 藤 $\bigcirc$ 笨 $\bigcirc$ 毁 & 20 & $\hat{\delta}$ & 下罯 & 0.2 & 直珠 & 淡黑色 & \\
\hline
\end{tabular}

・見习記截セバ次ノ如シ。

\section{I. 肉眼的所見}

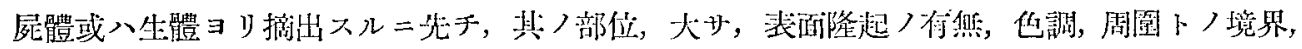

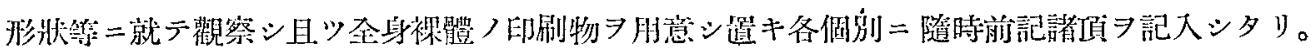

第 1 表寒喼例, 作及性别

\begin{tabular}{|c|c|c|c|c|c|c|c|c|c|c|c|}
\hline & 年鄂 & 不明 & $1-10$ & $\cdot 11-20$ & $21-30$ & $31-40$ & $41-50$ & $51-60$ & $61-70$ & $71-80$ & \\
\hline 年 & 男 & - & 12 & 10 & 26 & 21 & 30 & 23 & 3 & 3 & $1 \unlhd S$ \\
\hline 䍂命 & 女 & - & 16 & 10 & 17 & 29 & 21 & 8 & 2 & 1 & 104 \\
\hline 及 & 計 & 四 & $\overrightarrow{\vec{\lambda}}$ & $\overrightarrow{\mathrm{O}}$ & $\stackrel{\text { 四 }}{\equiv}$ & 五 & 五 & $\equiv$ & 五 & 四 & $(236$ 名 $)$ \\
\hline $\begin{array}{l}\text { 性 } \\
\text { 荈列 }\end{array}$ & $\%$ & $\overrightarrow{\dot{t}}$ & $\overrightarrow{\ddot{0}}$ & $\begin{array}{l}\text { 市. } \\
\text {. }\end{array}$ & $\vec{\pi}$ & $\begin{array}{l}\overrightarrow{\overline{0}} \\
\dot{\dot{0}}\end{array}$ & $\frac{\vec{\Xi}}{\dot{0}}$ & $\bar{\Xi}$ & $\frac{\overrightarrow{\ddot{0}}}{\overrightarrow{0}}$ & $\dot{t}$ & \\
\hline
\end{tabular}

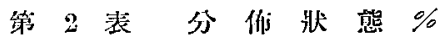

\begin{tabular}{|c|c|c|c|c|c|c|c|c|c|c|c|c|c|c|c|c|c|c|c|c|c|c|c|c|c|}
\hline 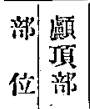 & $\begin{array}{l}\text { 前 } \\
\text { 䣄 } \\
\text { 部 }\end{array}$ & 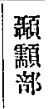 & 耳. & 㰾 & $\begin{array}{l}\text { 鼻 } \\
\text { 蔀 }\end{array}$ & 部 & $\mid \begin{array}{l}9 \\
\text { 園 } \\
\text { 部 }\end{array}$ & 涪初 & 部 & 部 & $\begin{array}{l}\text { 乳 } \\
\text { 唇 } \\
\text { 部 }\end{array}$ & $\begin{array}{l}\text { 腹 } \\
\text { 部 }\end{array}$ & $\begin{array}{l}\text { 厭 } \\
\text { 胛 } \\
\text { 部 }\end{array}$ & 部 & 部 & $\begin{array}{l}\text { 外 } \\
\text { 篭 } \\
\text { 部 }\end{array}$ & 琵 & $\begin{array}{l}\text { 火 } \\
\text { 怔 } \\
\text { 部 }\end{array}$ & $\begin{array}{l}7 \\
\text { 费 } \\
\text { 部 }\end{array}$ & 涪 & 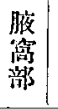 & $\begin{array}{c}\text { 肯 } \\
\text { 溥 } \\
\text { 部 }\end{array}$ & $\begin{array}{l}\text { 前 } \\
\text { 溥 } \\
\text { 蔀 }\end{array}$ & & \\
\hline 例 2 & 10 & 9 & 4 & 4 & 8 & 15 & 1 & 6 & 29 & 88 & 8 & 56 & 32 & 13 & 7 & 12 & $4^{\prime}$ & 43 & $28 !$ & 4 & 7 & 26 & 26 & 5 & \\
\hline$\%\left(\begin{array}{c}0 \\
\dot{\sigma}\end{array} \mid\right.$ & 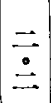 & $\overrightarrow{\dot{0}}$ & $?$ & $\begin{array}{l}0 \\
\text { 无 }\end{array}$ & $\overrightarrow{:}$ & $\begin{array}{l} \\
\vdots \\
\end{array}$ & 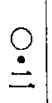 & $\ddot{\doteq}$ & 究 & $\begin{array}{l}\overrightarrow{\dot{O}} \\
\dot{0}\end{array}$ & $\overrightarrow{\dot{\lambda}}$ & 言 & $\stackrel{t}{ \pm}$ & $\dot{\bar{O}}$ & $\overrightarrow{\dot{\Xi}}$ & 亲 & $\begin{array}{l}0 \\
\text { 艺 }\end{array}$ & 九 & 六 & fi & $\dot{\dot{\pi}}$ & 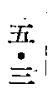 & 五 & & \\
\hline
\end{tabular}

(イ）部 位

第 1 表ニ示ス阴ク胘部 $20 \%$ ニシテ最モ多ク, 腹部 $12.4 \%$ ニデ之二次ギ, 大腿部 $9.6 \%$ 首 胛部, $7.1 \%$ トナリ其他ハー般ニ少シ

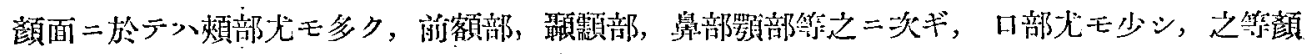
面部

頸部 $6.4 \%$ ニシテ相當多装ナリ。

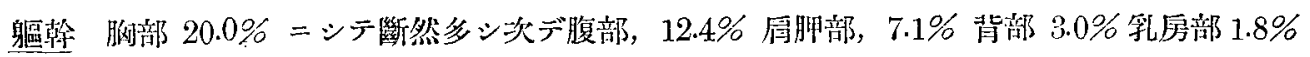
臂部 $1.5 \%$ 之等合訫 $45.8 \%$ トナナリ全身中尤モ多シ。

上抆上脯皮ビ朔膊 二多ク手背二少シ，合計 $11.7 \%$

下肢 大腿部二多ク，足背二進么二從ヒテ少シ，16.7\%

外陰部 陰卓 $2.6 \%$ 除裂 $0.9 \%$ 合計 $3.5 \%$ 
其他腋简部二於テ $1.5 \%$ 二存入。

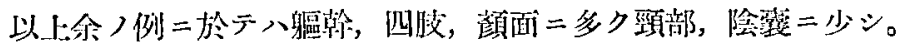

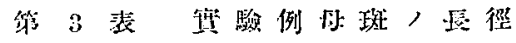

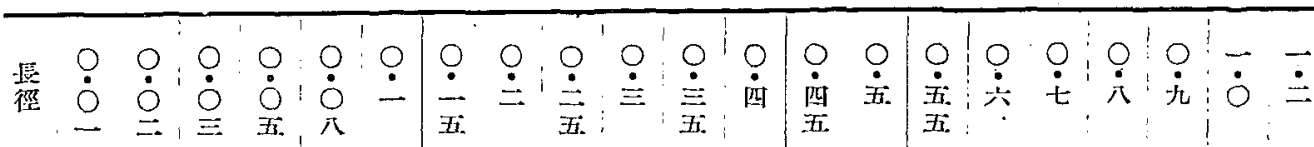

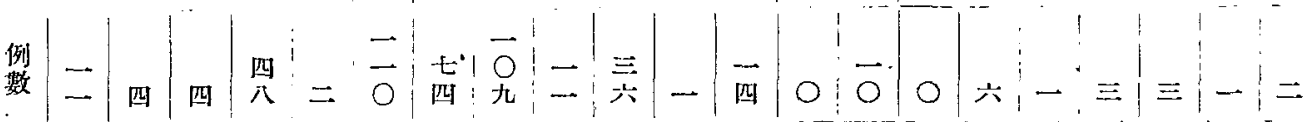

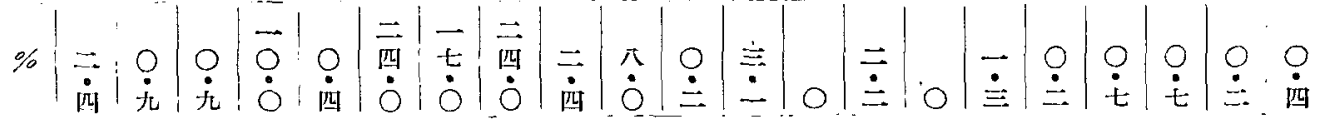

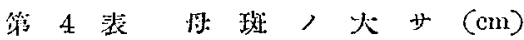

\begin{tabular}{|c|c|c|c|c|c|c|c|c|c|c|c|c|c|c|c|c|c|c|c|c|}
\hline 型 & $\dot{0}$ & 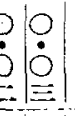 & $\begin{array}{l}0 \\
\dot{0} \\
\pm\end{array}$ & $\dot{0}$ & $\stackrel{?}{-}$ & $\left|\begin{array}{c}\underline{\dot{\theta}} \\
\overrightarrow{z_{i}}\end{array}\right|$ & 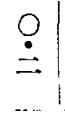 & $\left|\begin{array}{c}0 \\
\dot{\Xi} \\
\text { 五 }\end{array}\right|$ & $\stackrel{\varphi}{\dot{\Xi}}$ & 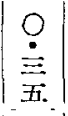 & $\mid \begin{array}{c}0 \\
\text { 四 }\end{array}$ & 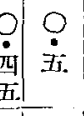 & 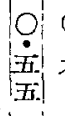 & $\begin{array}{l}0 \\
0 \\
\text { i }\end{array}$ & $\begin{array}{l}0 \\
t \\
t\end{array}$ & $\begin{array}{l}0 \\
\dot{\lambda}\end{array}$ & $\begin{array}{l}0 \\
\dot{C}\end{array}$ & $\overrightarrow{\dot{0}}$ & $\ddot{\vdots}$ & \\
\hline 第一型 & 1 & 2 & 4 & & 3 & 2 & 3 & 1 & & & & 1 & & & & & & & & \\
\hline 第二。型 & q 2 & 2 & 13 & I & .17 & 17 & 16 & 1 & 4 & & & 1 & & & & & & 1 & & \\
\hline 第三型 & & & 3 & 1 & 7 & 2 & 5 & & 3 & & & 1 & & & & & & & & \\
\hline 第四型 & 2 & 1 & 8 & & 20 & 20 & 14 & 3 & 6 & & 1 & 2 & & & & & & & & \\
\hline 第五型 & & & 6 & & 27 & 14 & 26 & 1 & 10 & 1 & 2 & 1 & & 1 & 1 & & & & & \\
\hline 第六型 & 1) 1 & & 8 & & 8 & 5 & 15 & & 5 & & 1 & & & & & & & & & \\
\hline 計 & 74 & & 42 & 2 & 82 & 60 & 79 & 6 & 28 & 1 & 4 & 6 & & 1 & 1 & & & 1 & & \\
\hline$\%$ & 2.11 .2 & 20.91 & 12.8 & 0.6 & 25.3 & 18.2 & 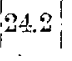 & 1.8 & 8.6 & 0.8 & 1.2 & 1.8 & & 0.3 & 0.8 & & & 0.3 & & \\
\hline 第一型 & 2 & 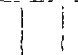 & 4 & & 8 & 3 & 7 & 2 & 1 & & 3 & & & & & & & & & \\
\hline 䈀第二型 & 1 & 1 & $I$ & & 5 & 3 & 8 & 1 & 3 & & 3 & & & & & & & & & \\
\hline 第三型 & & $!$ & & & 8 & 3 & 8 & & 1. & & 4 & 2 & & 2 & & 1 & 1 & & 1 & \\
\hline 第四型 & & & & & 2 & 8 & 2 & 1 & 1 & & & $I$ & & 1 & & & 1 & & & \\
\hline 第五型 & & & $1 !$ & & $3 !$ & & $3 !$ & & & & & 1 & & & & 1 & & & & \\
\hline 第二准 & & & & & & & & & 2 & & & & & 1 & & & & & 1 & \\
\hline 第七型 & & 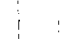 & . & & 1 & 2 & 1 & & & & & & & 1 & & & & & & \\
\hline 特殊型 & & & & & & & & & & & & & & & & 1 & 1 . & & & \\
\hline 群; 计 & & 1 & 6 & & 27 & 13 & 89 & 4 & 8 & & 10 & 4 & & 5 & & 3 & 3 & & & 11 \\
\hline$\%$ & 3.4 & $0.8^{i}$ & 5.0 & & 28.0 & 10.8 & 24.0 & $3.4:$ & 6.7 & & 9.0 & 3.4 & & 4.2 & & 2.5 & 2.5 & & 1.6 & \\
\hline
\end{tabular}

外 $\%$

25.025 .025 .025 .0

\section{(口) 츠}

本研究例ノ长徑 7 計測セシニ第 3 表ニ示ス如ク最モ多キハ 0.1 種乃至 0.2 種ニシテ 0.1 粴ノモ

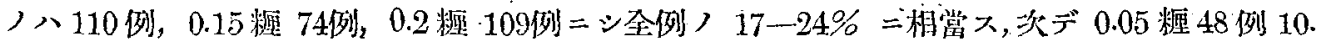

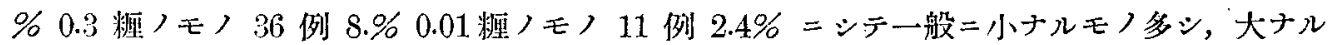


第5表 显斑形状

\begin{tabular}{|c|c|c|}
\hline 形 狀 & 例數 & $\%$ \\
\hline 圓 形 & $25 \mathrm{~S}$ & 57.3 \\
\hline 區方形 & 50 & 11.1 \\
\hline 格圆形 & 49 & 9.3 \\
\hline 小點狀 & 28 & 6.2 \\
\hline 三俑非 & 20 & 4.4 \\
\hline 四解形 & 17 & 3.9 \\
\hline 多脌形 & 11 & 2.4 \\
\hline 紀緟现 & 10 & 2.2 \\
\hline 程 状 & 9 & 2.0 \\
\hline 渄 形 & 3 & 0.6 \\
\hline , 爿 & 1 & 0.2 \\
\hline u宇状 & 1 & 0.2 \\
\hline
\end{tabular}

第一圆

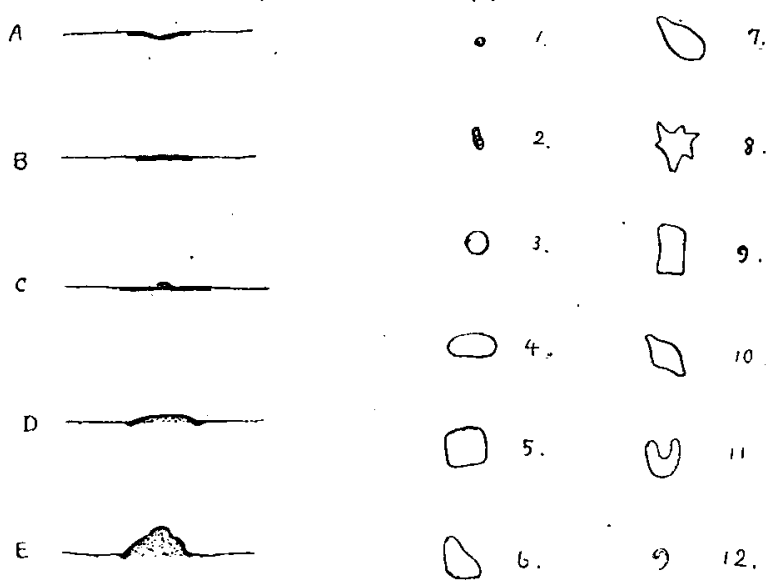

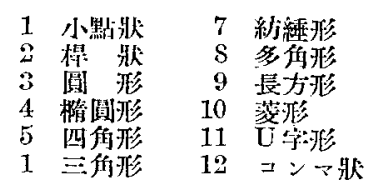

第 6 裴拇斑，形狀

\begin{tabular}{|c|c|c|c|c|c|c|c|c|c|c|c|c|c|c|}
\hline 群: & 㨐 爿 & $\begin{array}{l}\text { 圓 } \\
\text { 形 }\end{array}$ & $\begin{array}{l}\text { 棜 } \\
\text { 圆 } \\
\text { 形 }\end{array}$ & $\begin{array}{l}\text { 卧 } \\
\text { 形 }\end{array}$ & $\begin{array}{l}\text { 紬 } \\
\text { 緥 } \\
\text { 形 }\end{array}$ & $\begin{array}{c}\text { 勇 } \\
\text { 形 }\end{array}$ & $\begin{array}{l}\text { 多 } \\
\text { 角 }\end{array}$ & $\begin{array}{l}\text { 四 } \\
\text { 角 }\end{array}$ & $\begin{array}{l}\text { 悲 } \\
\text { 北 }\end{array}$ & $\begin{array}{l}\text { 小 } \\
\text { 點 } \\
\text { 狀 }\end{array}$ & $\begin{array}{l}\text { 㩐 } \\
\text { 狀 }\end{array}$ & $\begin{array}{c}\text {, } \\
\text { 状 }\end{array}$ & $\begin{array}{c}u \\
\text { 字 } \\
\text { 狀 }\end{array}$ & $\begin{array}{l}\text { 例 } \\
\text { 數 }\end{array}$ \\
\hline & 第一型 & $\mathrm{S}$ & & 1 & & & 1 & 1 & & 6 & & & & 17 \\
\hline 第 & 籍二。型 & 37 & 4 & 11 & -2 & 8 & 2 & 8 & 2 & 4 & 1 & & 1 & 75 \\
\hline & 第三三型 & 11 & 5 & 2 & 1 & & 1 & & & 2 & & & & 23 \\
\hline & 第四頨 & 4.3 & 12 & 4 & 1. & 5 & 2 & 3 & 1 & 3 & 2 & $I$ & & 77 \\
\hline & 第五型 & 51 & 4 & 16 & 3 & 3 & 2 & 7 & & 4 & 3 & & & 93 \\
\hline & 策六型 & 27 & 1 & 5 & 1 & 1 & 1 & 1 & & 5 & 1 & & & 48 \\
\hline 郡 & 部 & $17 \%$ & 26 & 39 & 8 & 17 & 9 & 15 & 3 & 84 & 7 & 1 & 1 & 327 \\
\hline & $\%$ & 54.4 & 7.8 & 11.9 & 2.4 & 5.2 & 2.7 & 4.6 & 0.9 & 7.3 & 2.1 & 0.3 & 0.3 & \\
\hline & 第一型 & 20 & 1 & $\dot{3}$ & & 2 & 1 & & & 1 & 2 & & & 80 \\
\hline 第 & 第二型 & 16 & 6 & 1 & & & & ! & & 2 & & & & 25 \\
\hline & 第三浲 & 21 & 4 & 4 & & & 1 & 1 & & $I$ & & & & 8 \\
\hline . & 筷四型 & 7 & 2 & 1 & 1 & 1 & & i & & 1 & & $\cdot$ & & 12 \\
\hline$\rightarrow$ & 独玨型 & 6 & 1 & 2 & & & & & & & & & & 9 \\
\hline$\rightarrow$ & 籍分型 & 2 & 1 & & & & & 1 & & & & & . & 4 \\
\hline & 第七型 & 5 & & & & & & ' & & & & & & 5 \\
\hline & 特殊智 & 1 & & & 1 & & & ; & & & & & & 2 \\
\hline 碓 & 䚵 & 78 & 15 & 11 & 2 & 3 & 2 & 2 & & 4 & 2 & & & 119 \\
\hline & $\%$ & 65.7 & 12.6 & 9.1 & 1.7 & 2.5 & 1.7 & 1.7 & & 3.3 & 1.7 & : & & \\
\hline 例 & 訣 & 3 & 1 & & & & & & & & . & & & 4 \\
\hline 外 & $\%$ & 75.0 & 25.0 & & & & & & & & & & & \\
\hline
\end{tabular}




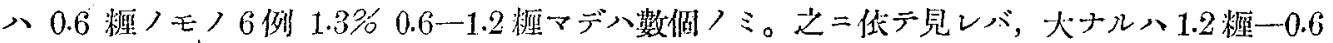

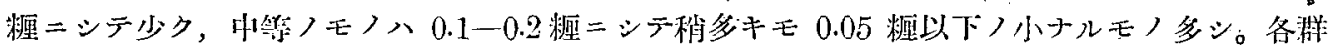

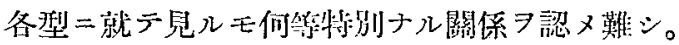

\section{(八) 森 犹}

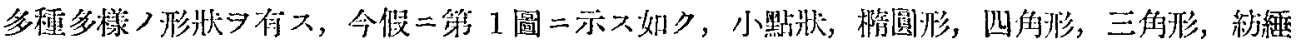

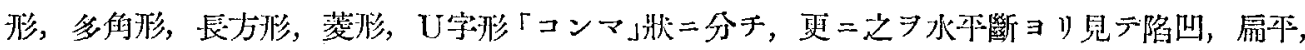

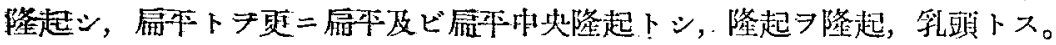

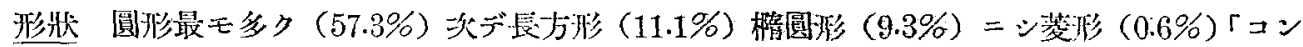
マ」状及ビU字狄 $(0,2 \%)$ 等八極メテ少シ

第 7 表 批珻/表面，狀態

\begin{tabular}{|c|c|c|c|c|c|}
\hline & 陷 & 蒚 & 平 & 隆 & 起 \\
\hline & 呵 & 㵢 平 & 中心隆起 & 隆 起 & 乳頍狀 \\
\hline 例 數 & 14 & 263 & 7 & $14: 0$ & 26 \\
\hline$\%$ & 32 & 58.3 & 1.6 & 31.0 & 5.9 \\
\hline 牕 計 & 14 & \multicolumn{2}{|c|}{270} & \multicolumn{2}{|c|}{166} \\
\hline$\%$ & 3.2 & & \multicolumn{2}{|c|}{$\begin{array}{l}-- \\
36.9\end{array}$} \\
\hline
\end{tabular}

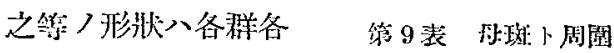
型二於テ何等特物入羅 係

二第 1 群二不正睃多》

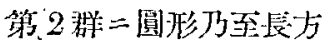
形多キガ如シ。

龯面 留雨ナルモノ $59.9 \%$ 占又多数 $=シ$

\begin{tabular}{|c|c|c|}
\hline 群 & 制 然 & 不 明 \\
\hline 第一稌 & 320 & 7 \\
\hline 第二票 & 115 & 4 \\
\hline 例 外 & 4 & \\
\hline 詰 & 439 & 11 \\
\hline$\%$ & 97.6 & 2.4 \\
\hline
\end{tabular}
テ隆起七ルモノ，36.9\% ぞ二炏ギ，却テ陷凹七ル モノ $3.2 \%$ ノ少数二見习ル。

第 1 群八表䤄扇平ナルモ) (72.8\%)多ク或八却 ツデ陷凹スレドモ第 2 洋八隆起セルモ> $78.9 \%$,

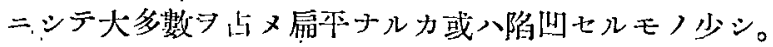

\section{（二）閣園卜ノ境界}

第 8 表二亦ス如ク一般二境界制然夕り。

（ホ）画訶
第 8 表 㳩玫，表面

\begin{tabular}{|c|c|c|c|c|c|c|c|}
\hline 群 & $\begin{array}{l}\text { 表 } \\
\text { 通狀 } \\
\text { 竾 }\end{array}$ & 陷 & 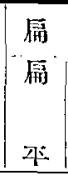 & $\begin{array}{l}\text { 本 } \\
\text { 中 } \\
\text { 心 } \\
\text { 隆 } \\
\text { 过地 }\end{array}$ & $\begin{array}{c}\frac{\text { 隆 }}{-} \\
\text { 隆 } \\
\text { 起 }\end{array}$ & $\begin{array}{l}\text { 起 } \\
\text { 乳 } \\
\text { 頭 } \\
\text { 狀 }\end{array}$ & 數 \\
\hline \multirow{3}{*}{ 第 } & 㩁一型 & 1 & 13 & & 3 & & 17 \\
\hline & 第二型 & $\check{5}$ & 160 & & 8 & 1 & 74 \\
\hline & 第三型 & & 6 & 1 & 14 & 2 & 23 \\
\hline \multirow{3}{*}{-} & 第四型 & 1 & 58 & & 14 & 4 & 77 \\
\hline & 第五型 & 4 & 67 & 2 & is & 2 & 98 \\
\hline & 第六型 & 1 & 34 & 3 & 5 & & 43 \\
\hline \multirow[t]{2}{*}{ 群 } & 計 & 12 & 238 & 6 & 62 & 9 & 327 \\
\hline & $\%$ & 3.6 & 72.8 & 1.8 & 18.9 & 2.7 & \\
\hline \multirow{4}{*}{ 第 } & 第一型 & & 9 & 1 & 20 & & 30 \\
\hline & 第二型 & 8 & 5 & & 13 & 5 & 25 \\
\hline & 穿三型 & & 4 & & 21 & 7 & 32 \\
\hline & 第四型 & & & & 10 & 2 & 12 \\
\hline \multirow{4}{*}{$\Rightarrow$} & 第五型 & & 4 & & 4 & 1. & 9 \\
\hline & 第六型 & & & & 4 & & 4 \\
\hline & 第七犁 & & & & 5 & & 5 \\
\hline & 特殊型 & & & & & 2 & 2 \\
\hline \multirow[t]{2}{*}{ 群 } & 計 & 2 & 22 & 1 & 77 & 17 & 119 \\
\hline & $\%$ & 1.7 & 18.4 & 0.9 & 64.7 & 14.3 & \\
\hline \multirow{2}{*}{$\begin{array}{l}\text { 例 } \\
\text { 外 }\end{array}$} & 計 & & 3 & & 1 & & 4 \\
\hline & $\%$ & & 75.0 & & 25.0 & & \\
\hline
\end{tabular}


第 10 装奜球, 色铜

\begin{tabular}{|c|c|c|c|c|c|c|c|c|}
\hline 碓 & 垈 & $\begin{array}{l}\text { 淡 } \\
\text { 黑 } \\
\text { 色 }\end{array}$ & $\begin{array}{l}\text { 黑 } \\
\text { 他 }\end{array}$ & $\begin{array}{l}\text { 褐 } \\
\text { 色 }\end{array}$ & $\begin{array}{l}\text { 淡 } \\
\text { 褐 } \\
\text { 色 }\end{array}$ & $\begin{array}{l}\text { 青 } \\
\text { 墨 } \\
\text { 色 }\end{array}$ & $\begin{array}{l}\text { 淡 } \\
\text { 意 } \\
\text { 色 }\end{array}$ & $\begin{array}{l}\text { 例 } \\
\text { 數 }\end{array}$ \\
\hline \multirow{3}{*}{ 第 } & 第一型 & 6 & 6 & 2 & 3 & & & 17 \\
\hline & 第二型 & 29 & 31 & 7 & 8 & & & 75 \\
\hline & 籊三型 & 6 & 5 & 3 & 8 & & & 22 \\
\hline \multirow{3}{*}{$\rightarrow$} & 籍四型 & 16 & 48 & 11 & 7 & & & 77 \\
\hline & 第五型 & 16 & 56 & 17 & 4 & & 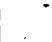 & 93 \\
\hline & 第六型 & 7 & 87 & 4 & & & & 43 \\
\hline \multirow[t]{2}{*}{ 群 } & 計 & 80 & 173 & 44 & 30 & & & 329 \\
\hline & $\%$ & 24.4 & 52.9 & 13.4 & 9.1 & & & \\
\hline \multirow{4}{*}{ 第 } & 第一型 & 14 & 15 & 1 & & & & 30 \\
\hline & 第二型 & 13 & 7 & 5 & & & & 25 \\
\hline & 第三型 & 14 & 11 & 3 & 3 & 1 & & 32 \\
\hline & 第四型 & 11 & & $I$ & & & & 12 \\
\hline \multirow{2}{*}{ 三 } & 第五型 & 2 & 5 & 1 & & & 1 & 9 \\
\hline & 第六型 & 1 & 2 & 1 & & & & 4 \\
\hline \multirow{4}{*}{ 群 } & 第七型 & 1 & 3 & 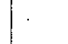 & 1 & & & 5 \\
\hline & 特殊䓄 & 2 & & & & & & 2 \\
\hline & 計 & 58 & 43 & 12 & 4 & 1 & 1 & 119 \\
\hline & $\%$ & 4.9 .5 & 36.1 & 10.9 & 3.4 & 0.8 & 0.8 & \\
\hline \multirow{2}{*}{ 例 } & 部 & 2 & 1 & & 1 & & & 4 \\
\hline & $\%$ & 50.0 & 25.0 & & 25.0 & & & \\
\hline
\end{tabular}

1. 黑色, 淡黑色, 袑色, 淡褐色, 青黑色, 淡 青色第二分類スル二第 1 洋八黑色最モ多ク（52.9 ％）炏デ淡黑色 $(24.4 \%)=$ シテ第 2 群八淡黑色,

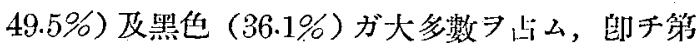

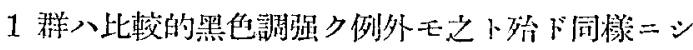
テ, 第 2 群八黑色調淡シ。

2. 鱼調卜表面然態上ノ關係 $习$ 見ル二第 11 表

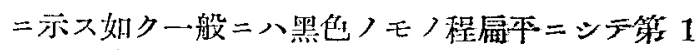
臂八黑色扇平ナルモ>琶モ多ク (33.3\%) 第2 群 八淡㷛色隆起七儿モノ多ク（40.0\%）哭他隆起七 ルモノ(25.2\%) 之二次グ，而シテ黑何ヨリ褐色一 淡褐色二進么二從七テ隆起七ルモノ多シ，即千第

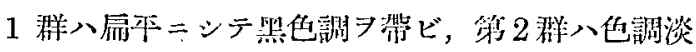

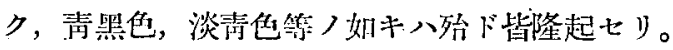

\section{(へ) 毛笶}

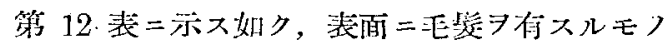
$3.0 \%$ ：シテ准セザルモ， $97.0 \%$ =シテ肉腿上. 八殆ド毛䰊シ兌ズ。

第 11 裴色調卜表面牀慧

\begin{tabular}{|c|c|c|c|c|c|c|c|c|c|c|c|c|c|c|c|c|}
\hline \multirow{3}{*}{\multicolumn{2}{|c|}{ 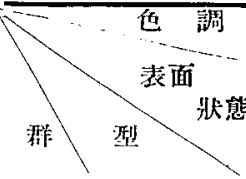 }} & 淡 & 黑 & 色 & 黑 & & 色 & 䶂 & & 巴 & 淡 & 裀 & 化 & 责 & 淡 & 例 \\
\hline & & 扁 & 隆 & 陷 & 暦 & 隆 & 陷 & 㕄 & 隆 & 熦作 & 廨 & 隆 & 低 & 色 & 屏 & \\
\hline & & 平 & 起 & 四 & 平 & '起 & 凹曰 & य1: & 起 & щ & 平 & 起 & 阴 & 起 & 琶 & 數 \\
\hline \multirow{3}{*}{ 籍 } & 第一型 & 6 & & & 4 & 1 & $I$ & 2 & & & 1 & $2^{\prime}$ & & & & 17 \\
\hline & 第二型 & 29 & 3 & 4 & 27 & 3 & 1 & 7 & & & 4 & 4 & & & & 75 \\
\hline & 第三犁 & 3 & 3 & & 3 & 1 & & 1 & 3 & & 1 & 7 & & & & 23 \\
\hline & 综 四 型 & 11 & 5 & & 36 & 6 & 1 & 9 & 2 & & 2 & 5 & & & & 77 \\
\hline & 第五型 & 12 & 4 & & 48 & 7 & 1 & 9 & 5 & 3 & & 4 & & & & 93 \\
\hline & 第六型 & 5 & 2 & & 29 & 3 & & 3 & & 1. & & & & & & 43 \\
\hline \multirow[t]{2}{*}{ 灌 } & 塥 & 58 & 17 & 4 & 109 & 21 & 4 & 31 & 10 & 4 & 8 & 22 & & & & 327 \\
\hline & $\%$ & 17.7 & 5.2 & 1.2 & 38.3 & 6.4 & 1.2 & 9.5 & 3.1 & 1.2 & 2.4 & 6.7 & & & & \\
\hline \multirow{4}{*}{-} & 第一型 & 6 & 8 & & 4 & 11 & & & 1 & & & i & & & & 30 \\
\hline & 第 二 型 & 1 & 11 & 1 & 3 & 3 & 1 & 1 & 4 & & & & & & & 25 \\
\hline & 籍三型 & 1 & 13 & & 3 & 8 & & & 3 & & . & 3 & & 1 & & 32 \\
\hline & 第四型 & & 11 & & & & & & & $\therefore$ & & 1 & & & & 12 \\
\hline$=$ & 笘 五型 & 1. & 1 & & 2 & 3 & & 1 & & & & & & & 1 & 9 \\
\hline
\end{tabular}




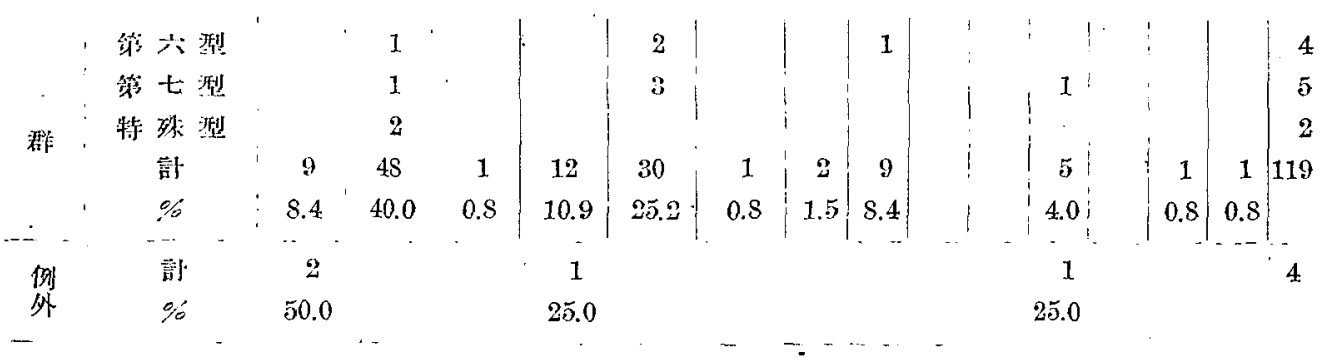

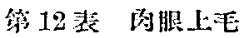
有艁

\begin{tabular}{r|r|r}
\hline & 有 & 然 \\
\hline 群 & & \\
\hline 第一群 & 1 & 326 \\
第二群 & 11 & 108 \\
例 外 & 1 & 8 \\
計 & 13 & 437 \\
$\%$ & 2.9 & 97.1 \\
\hline
\end{tabular}

\section{（1）第冣 群}

\section{1. 第 一 型}

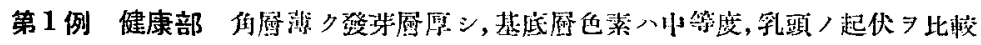

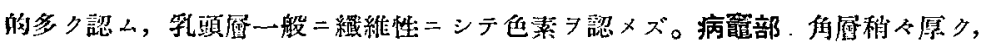

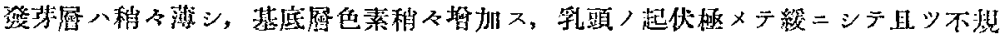

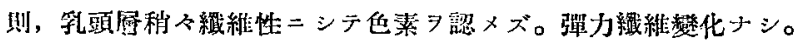

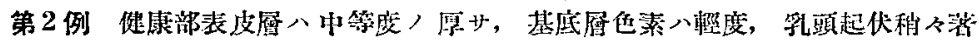

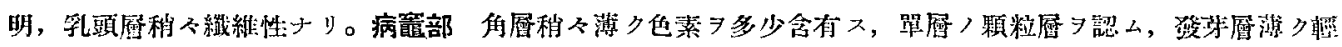

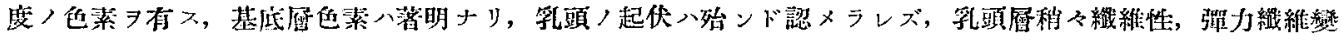
化於。

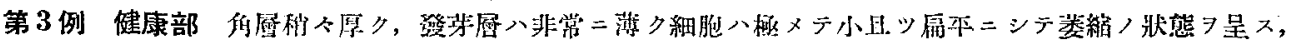

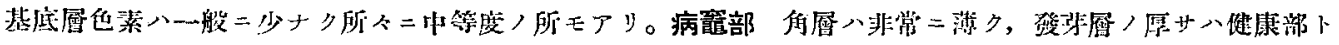

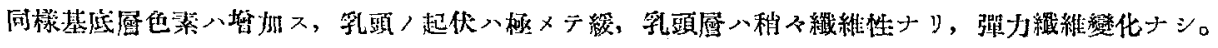

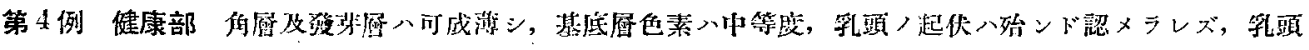

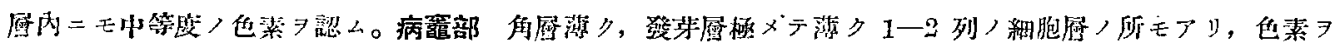

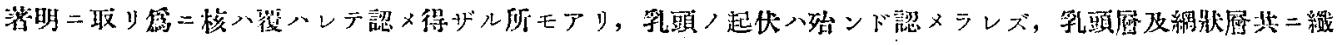

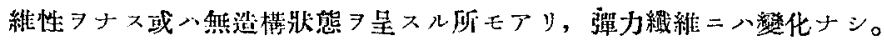

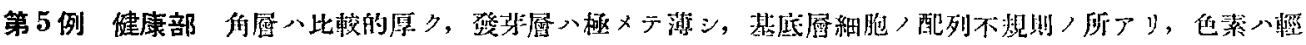

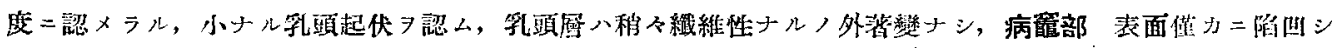

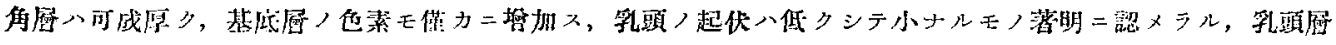

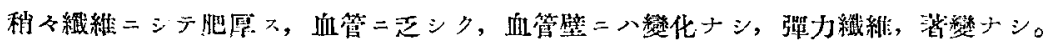

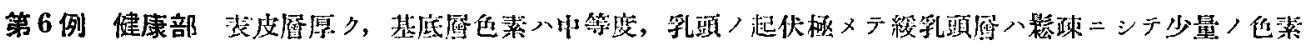
毛細管壁二勁

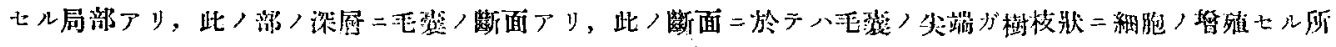

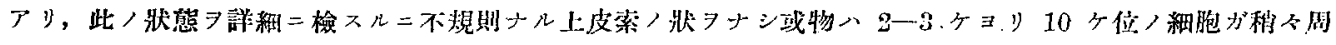

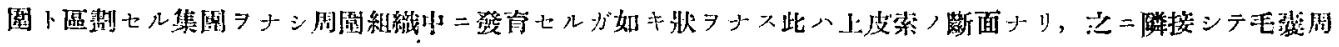

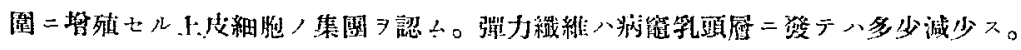


㪚 微 鏡的所㫕

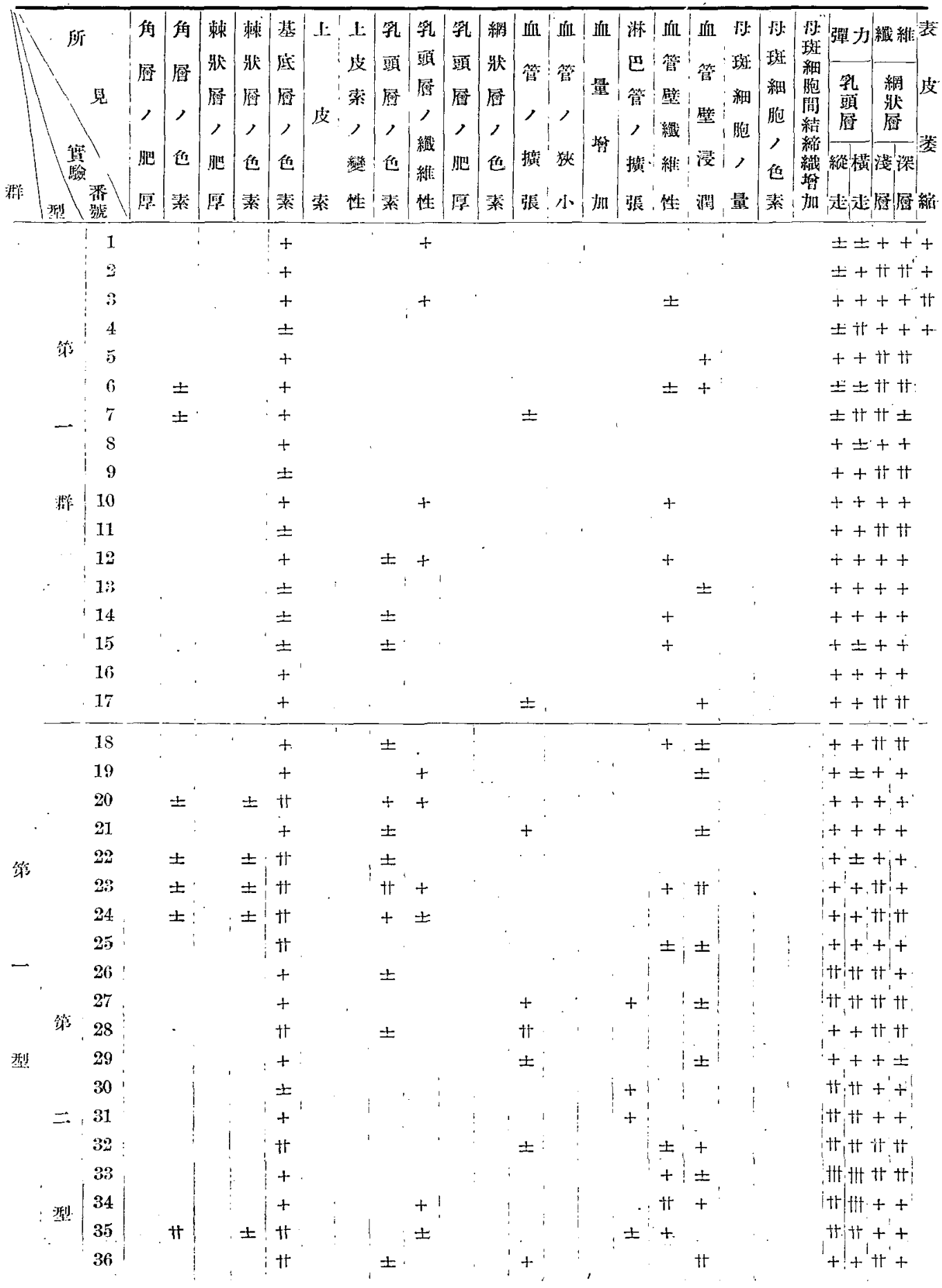




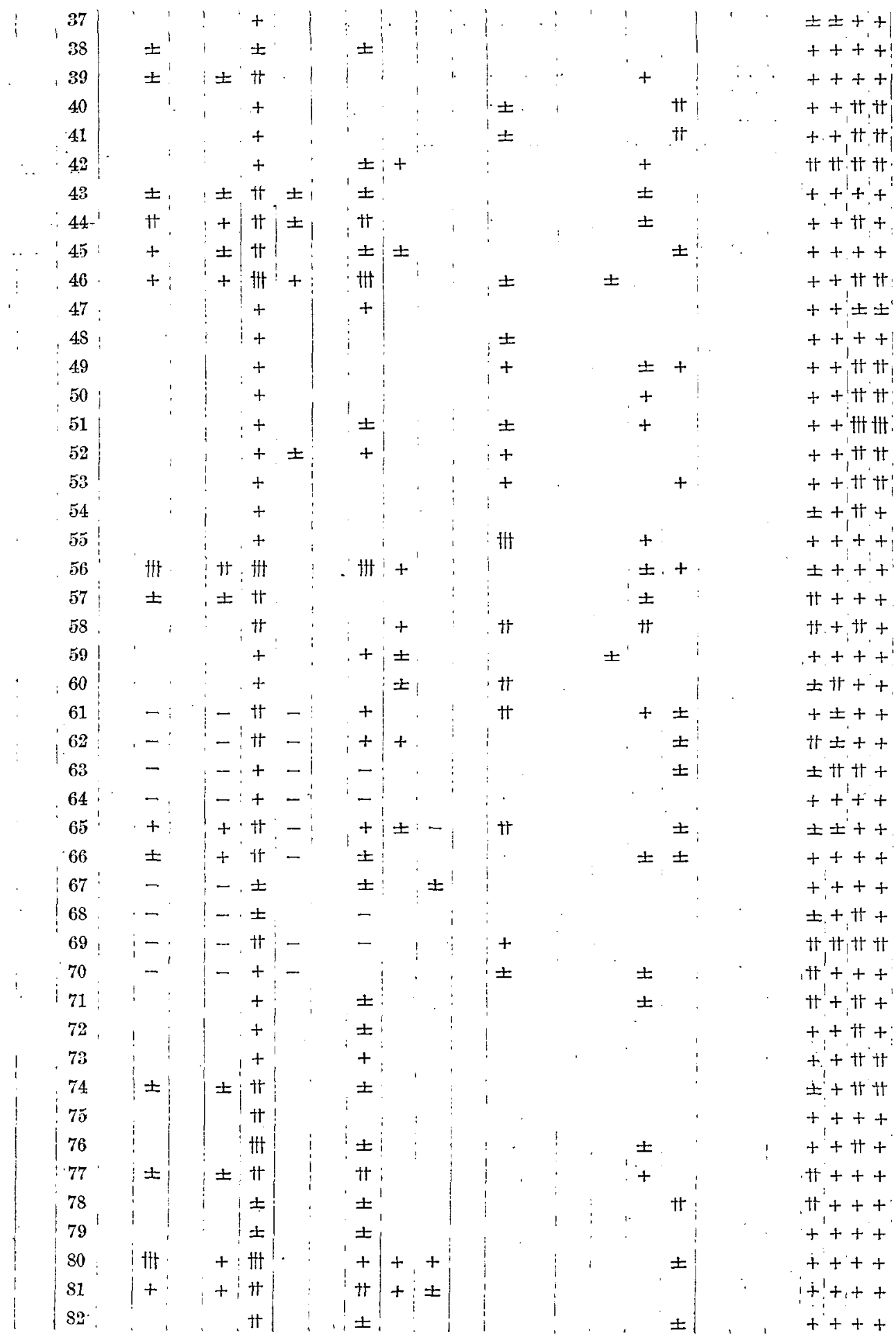




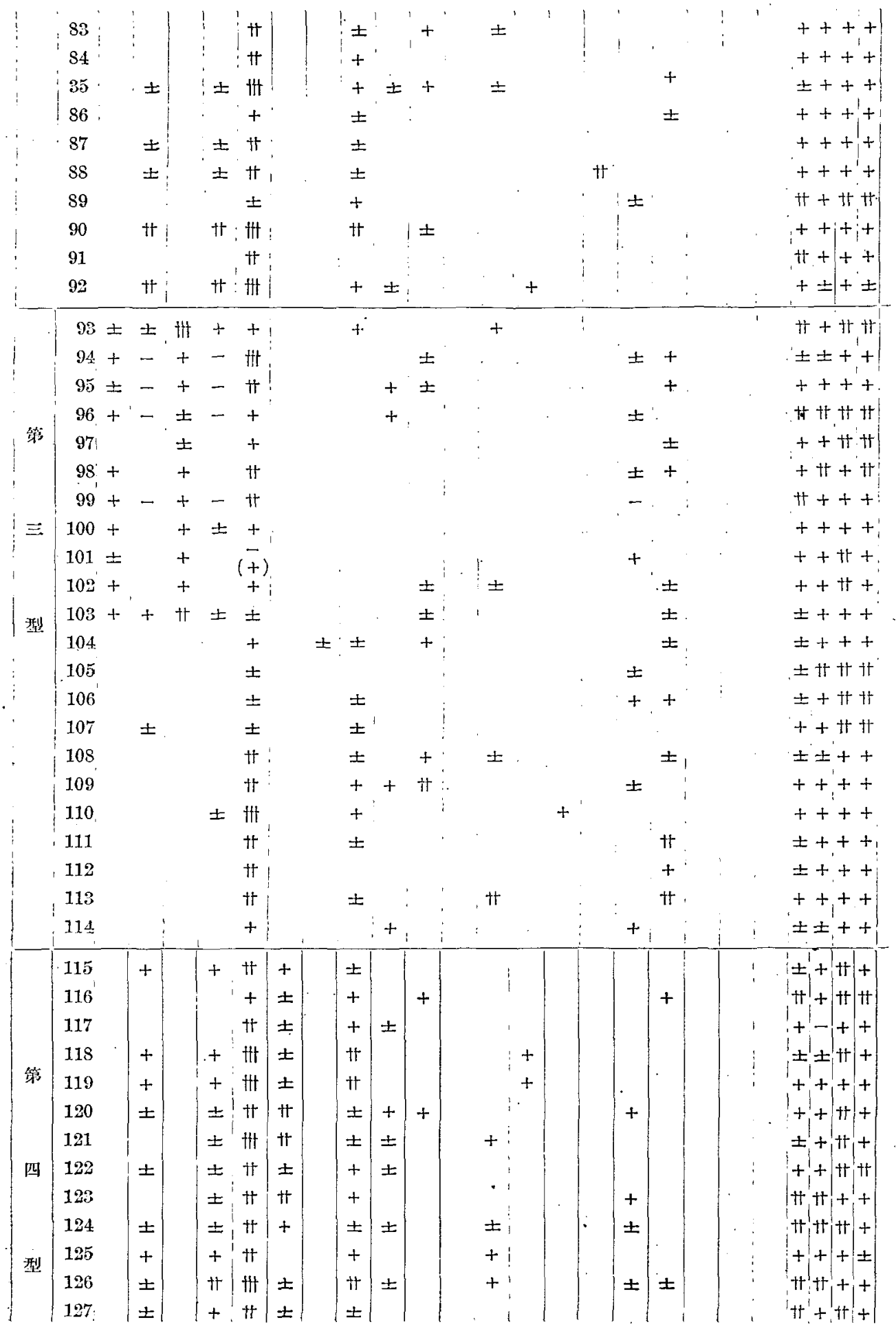




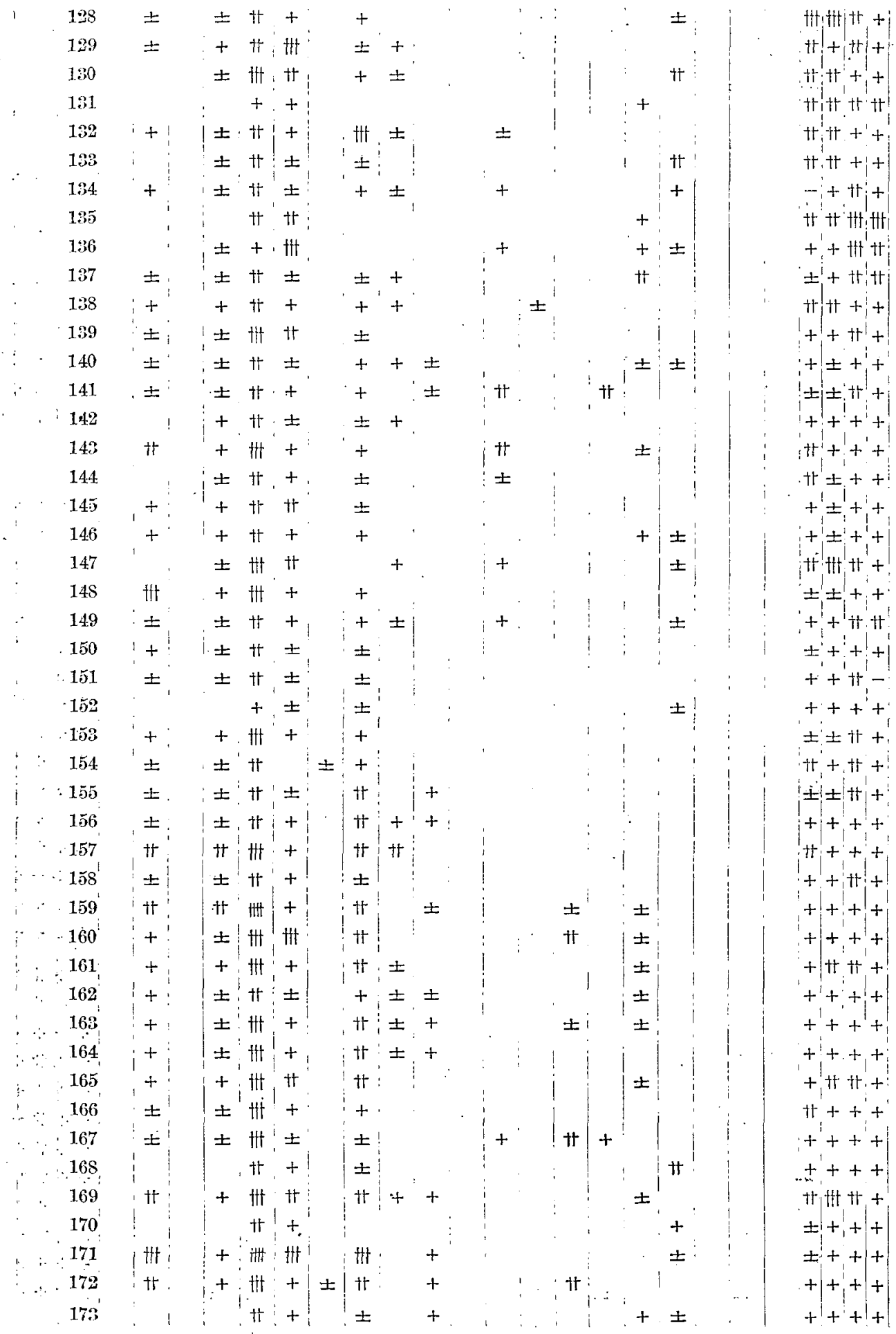




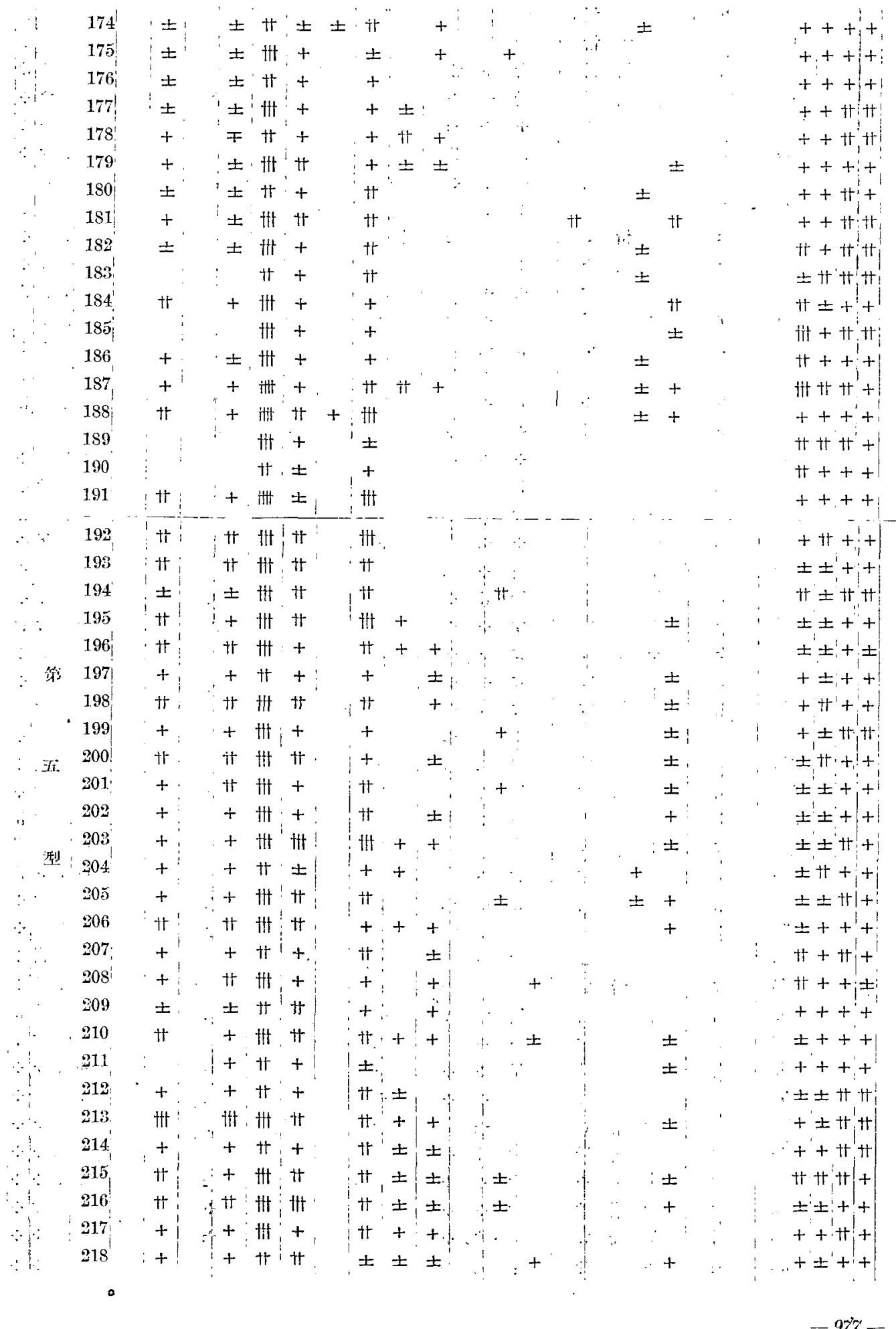




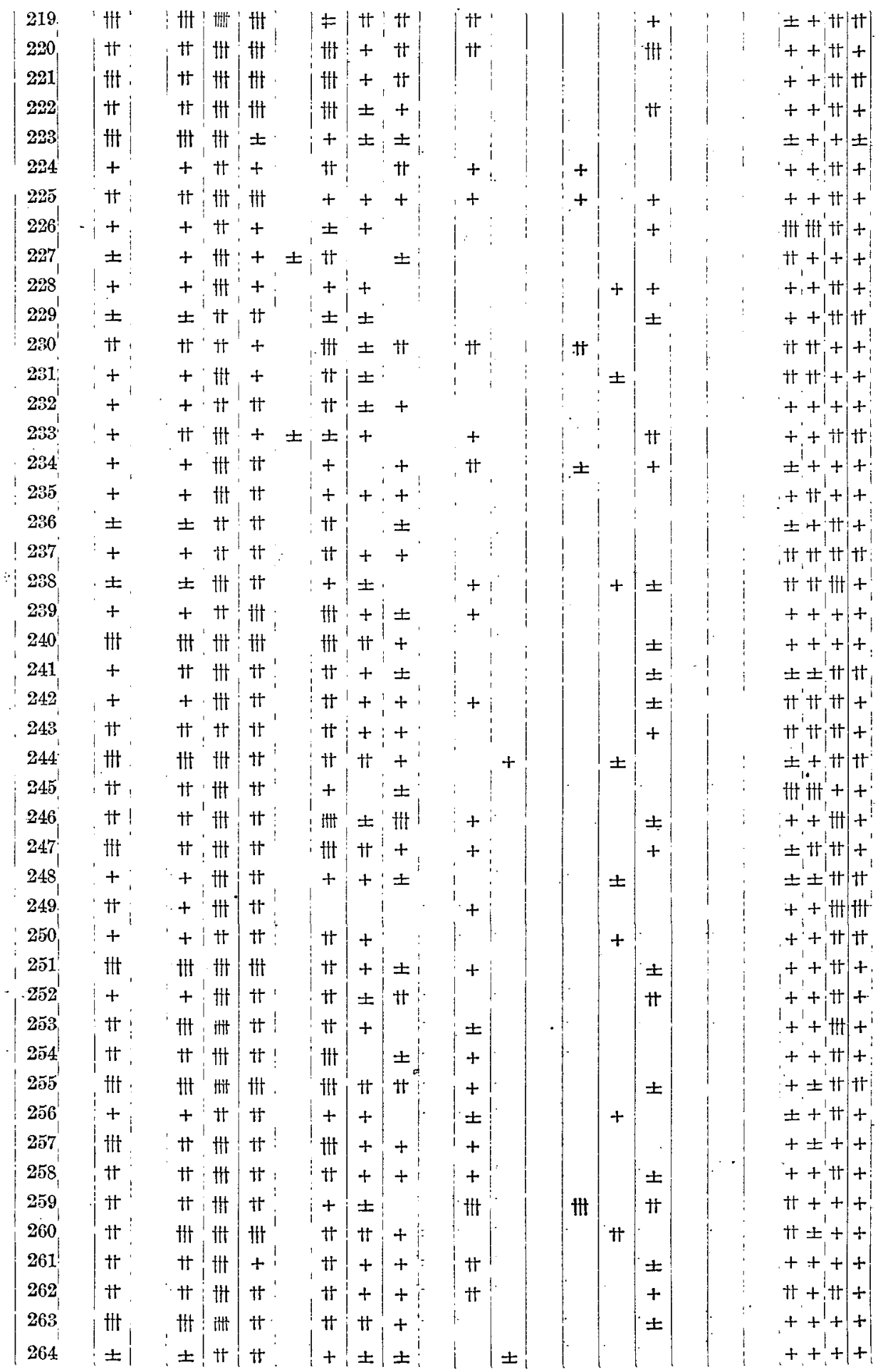




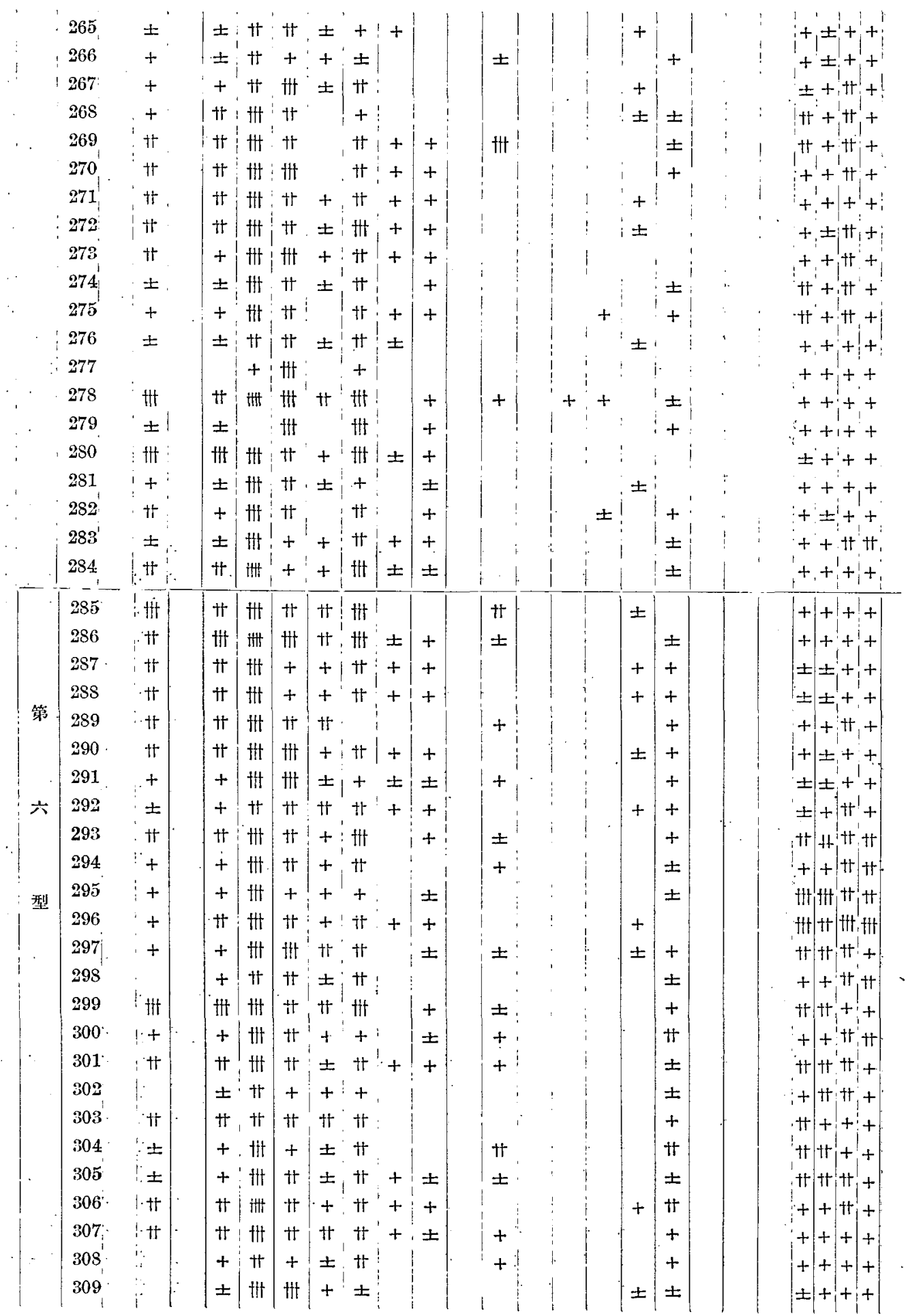




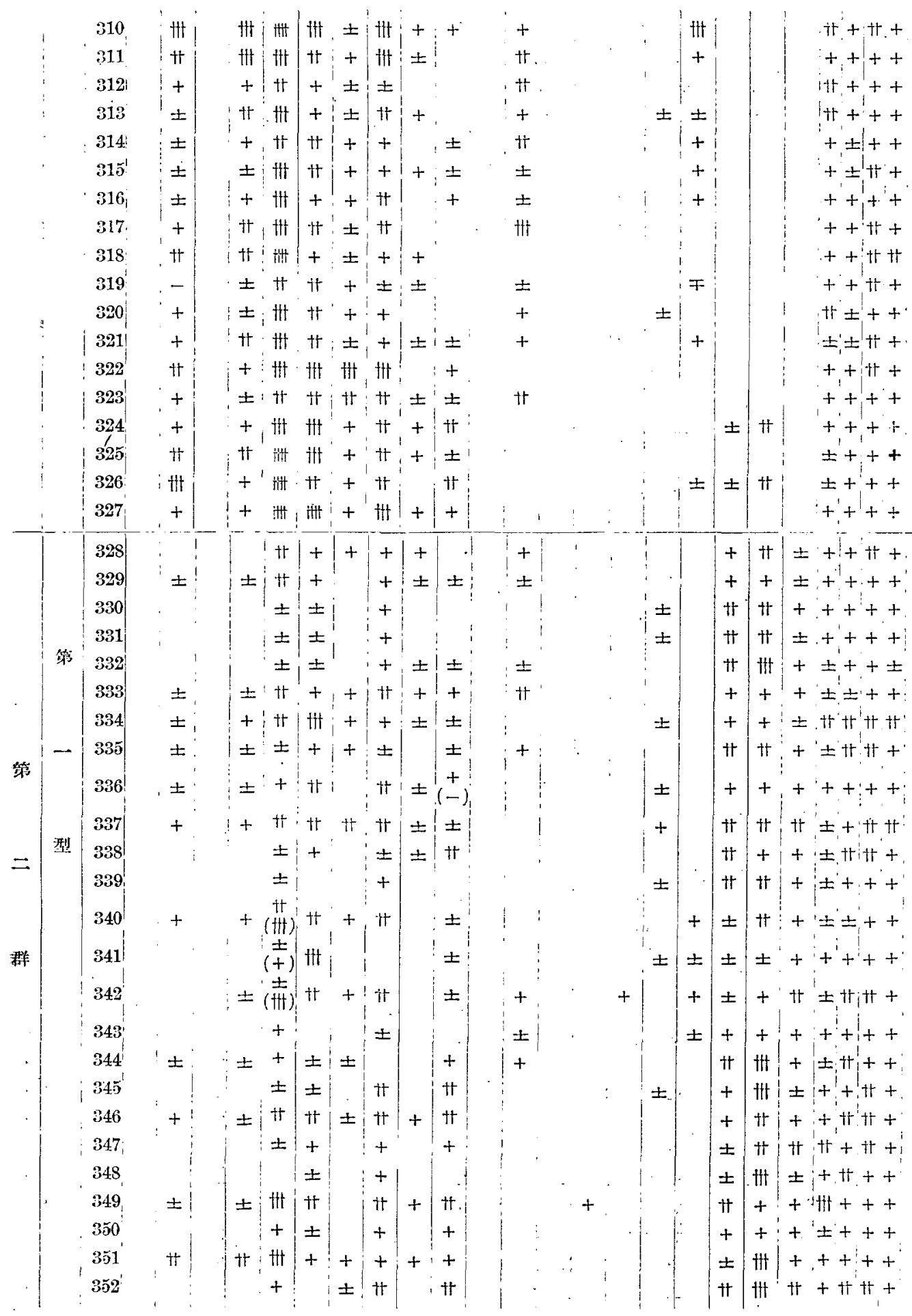




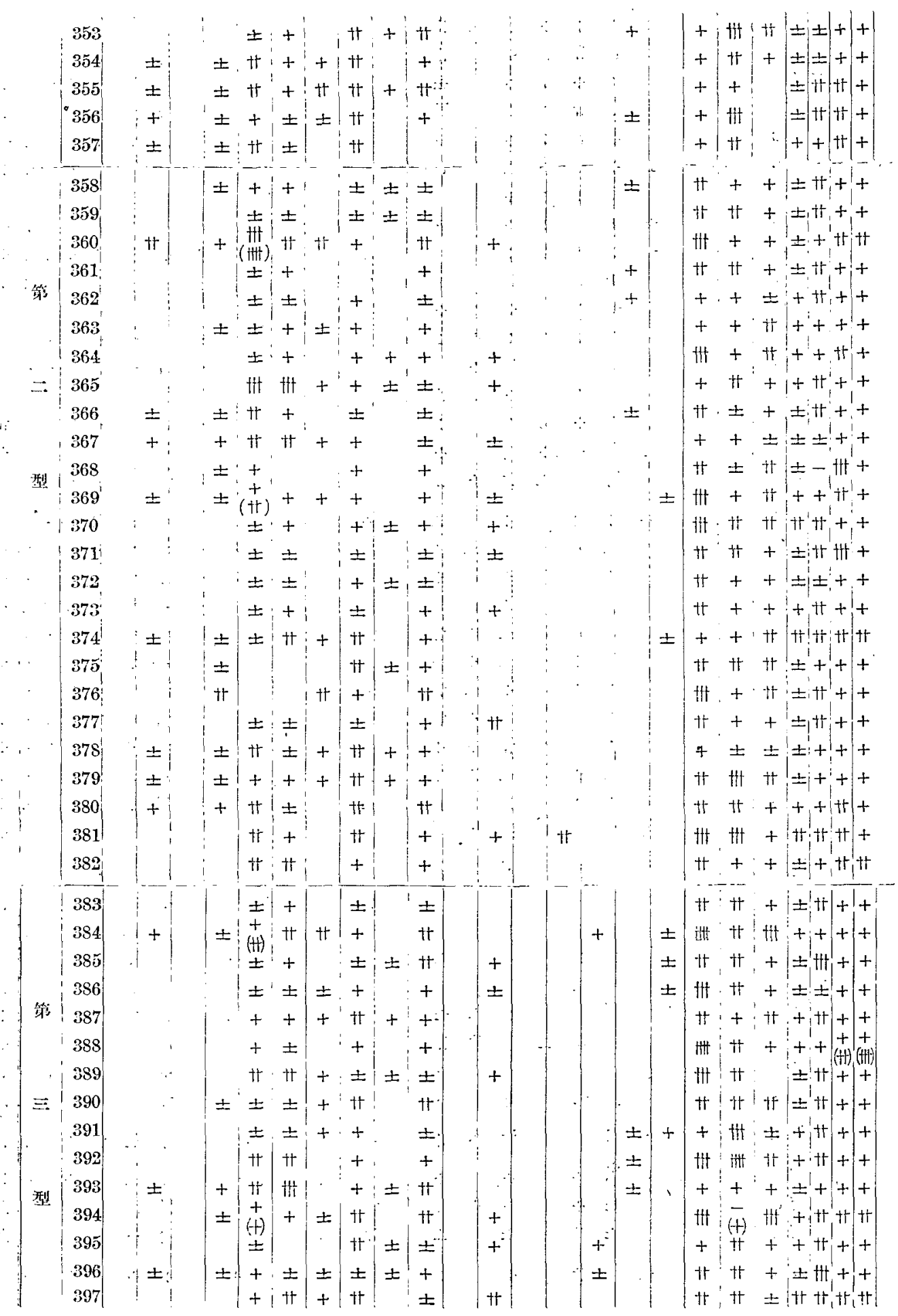




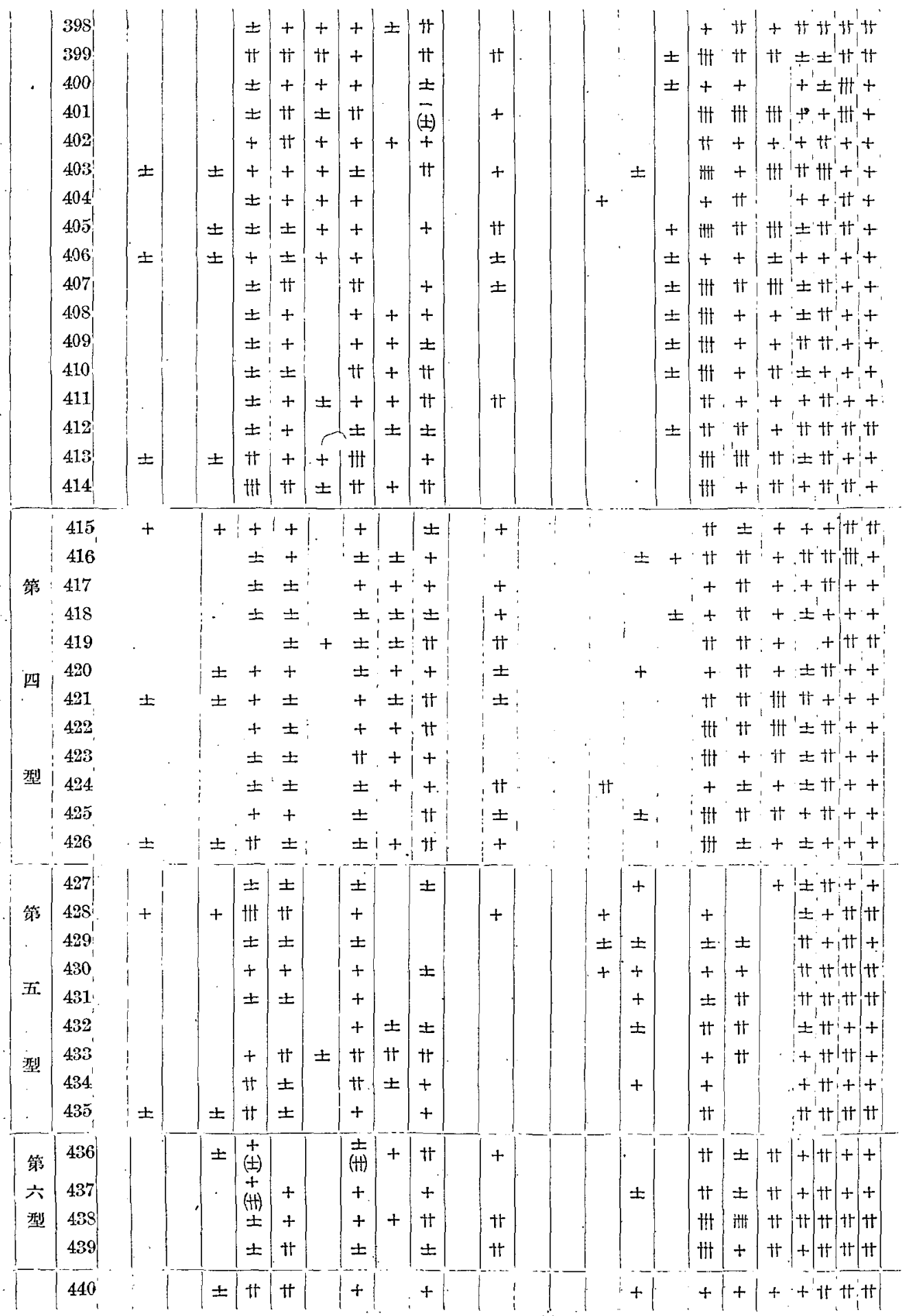




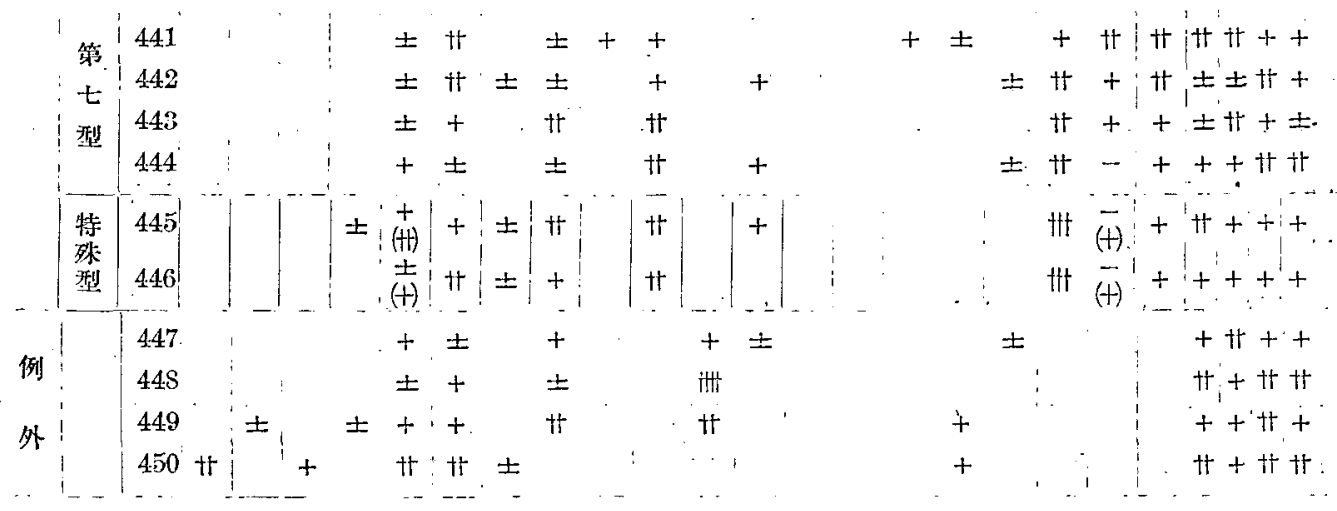

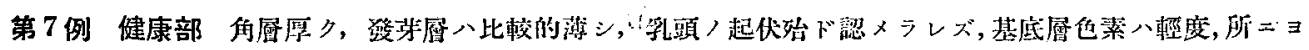

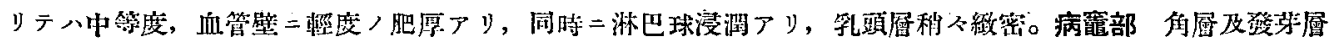

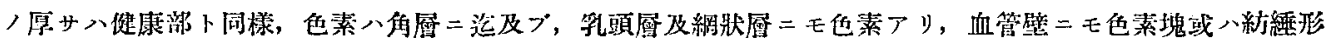

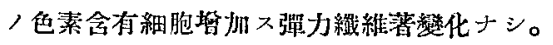

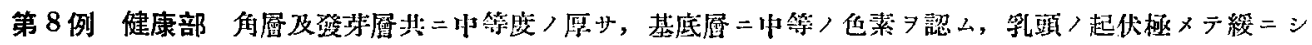

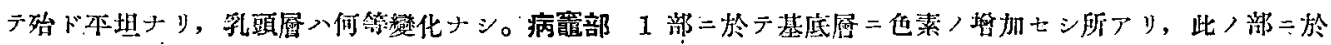

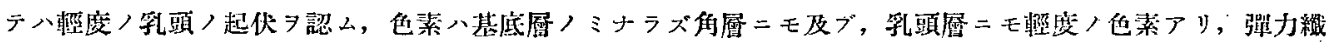
維, 浠化ナシ。

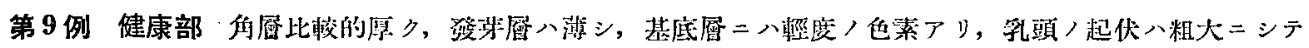

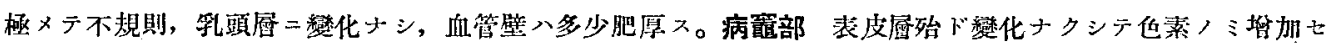

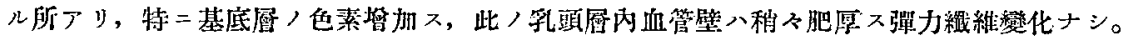

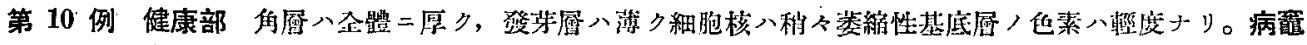

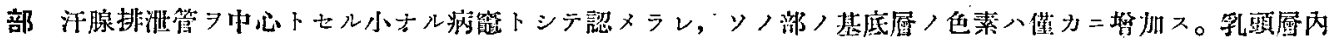
ニ色素ヨ認メズ，他二化ナシ，彈力縜維モ亦化ナシ。

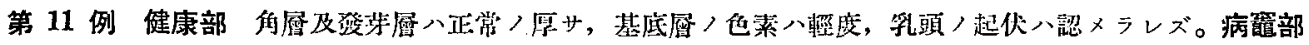

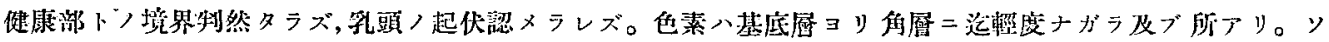

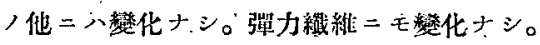

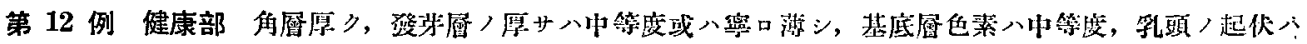

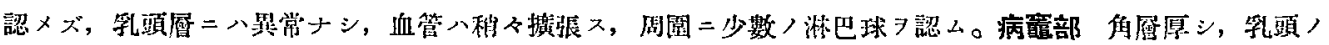

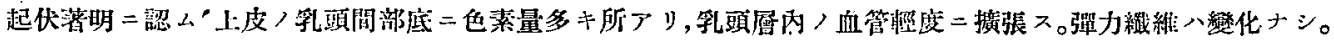

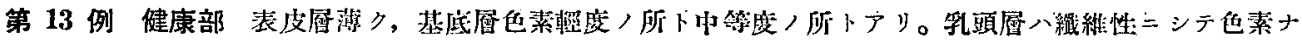

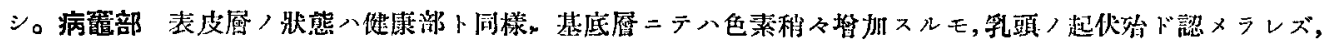

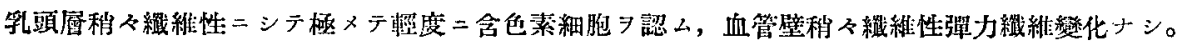

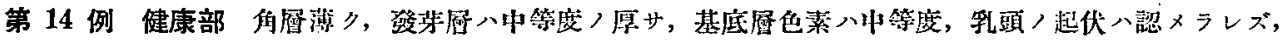

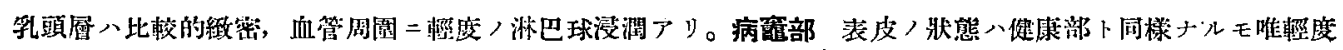




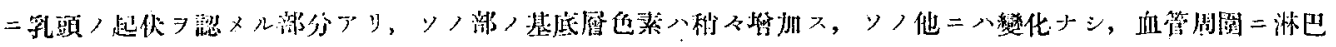

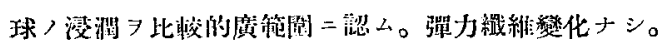

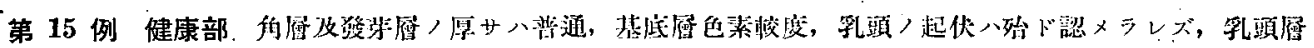

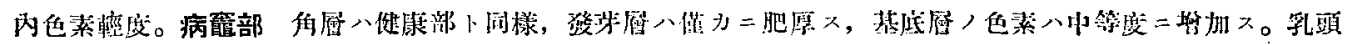

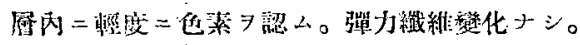

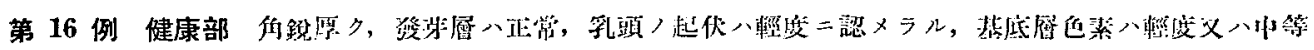

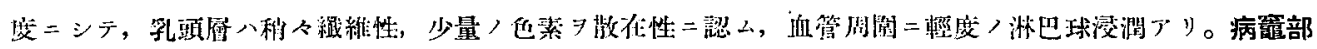

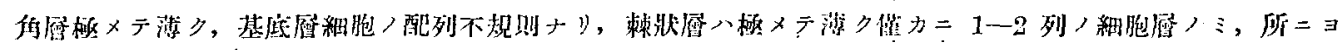

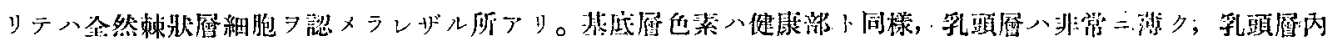

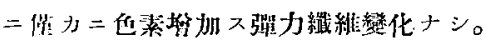

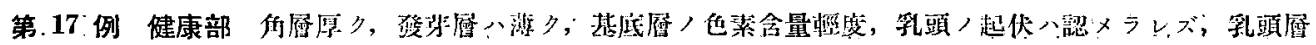

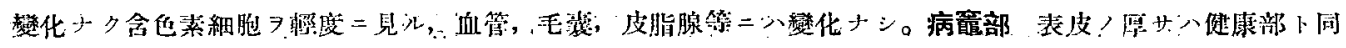

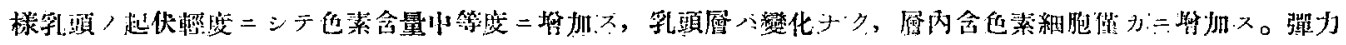

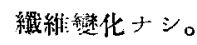

\section{2. 第 二 型}

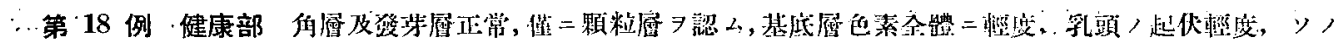

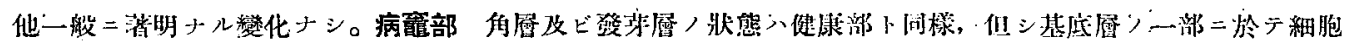

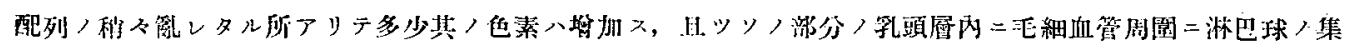

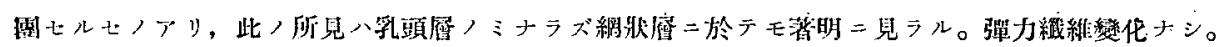

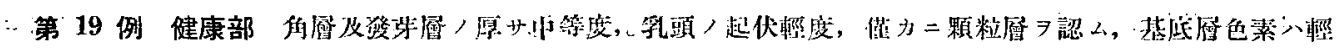

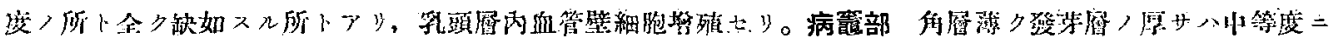

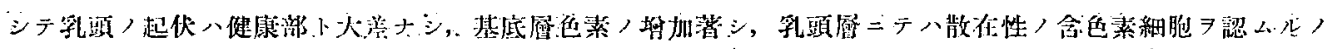

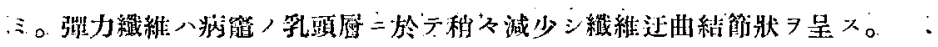

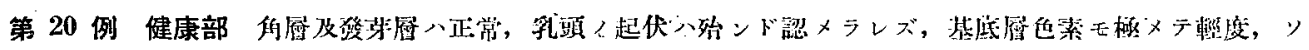

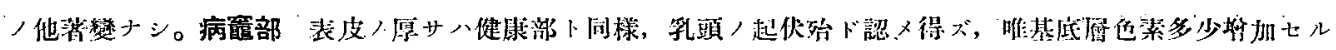

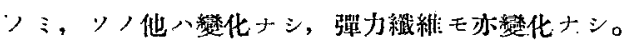

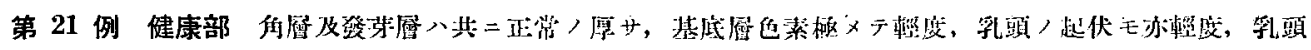

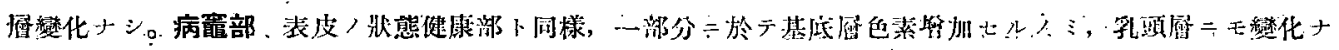
$シ$, 腨力饿維變化ナシ。:

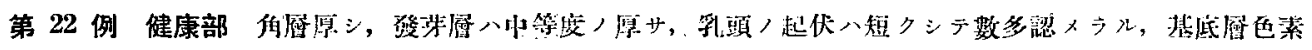

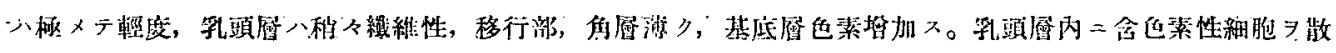

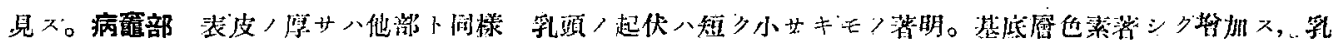

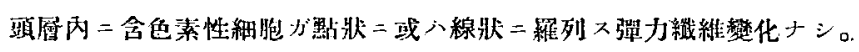

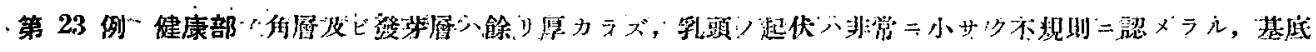

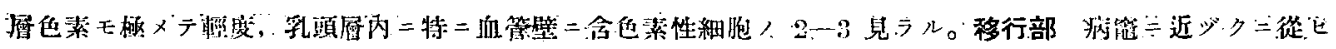




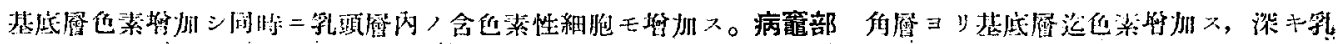

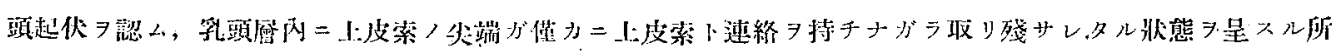

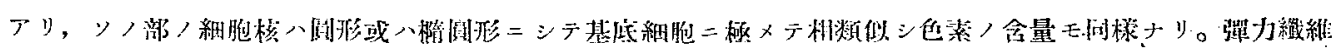
八継化ナシ。

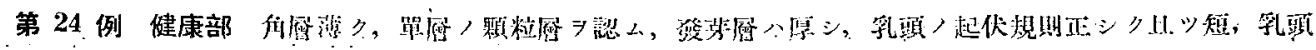

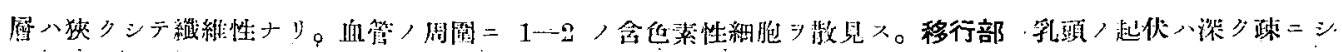

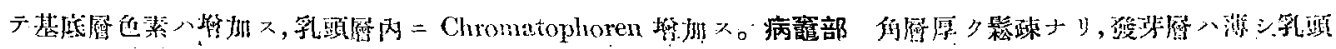

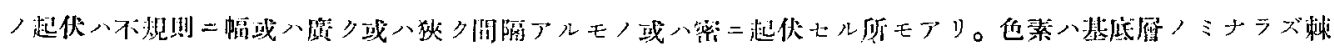

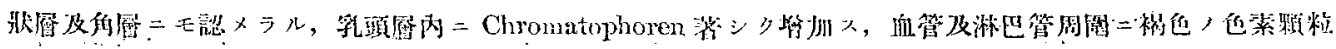

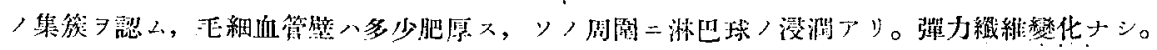

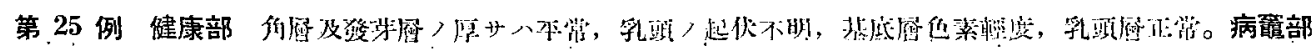

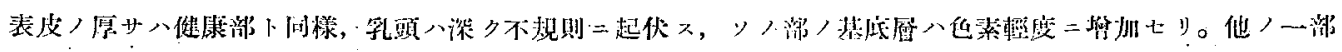

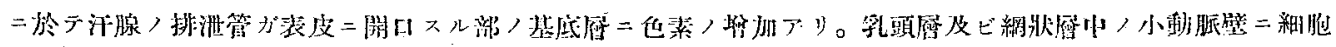

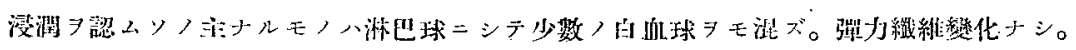

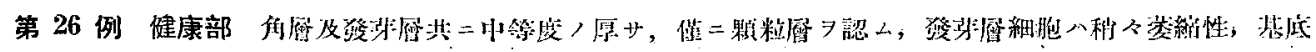

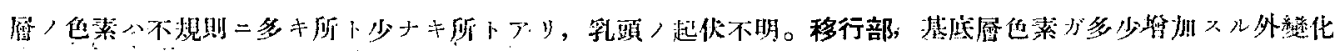

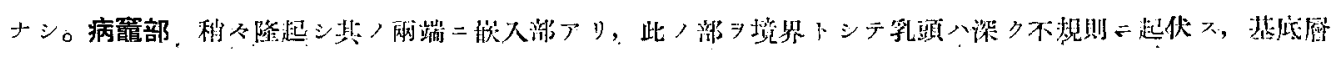

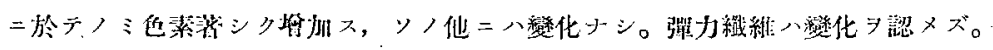

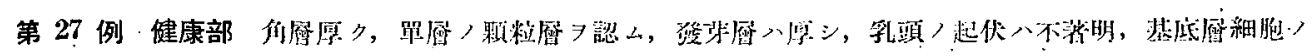

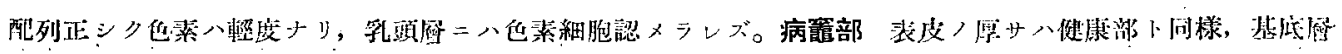

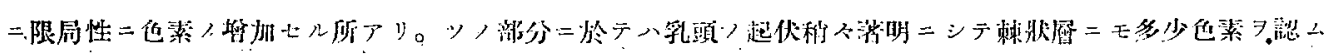

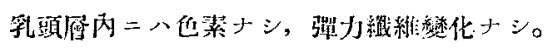

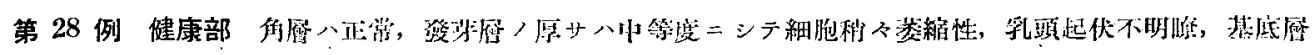

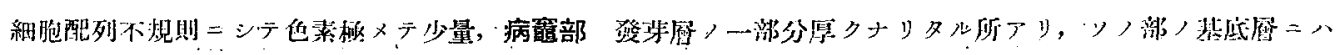

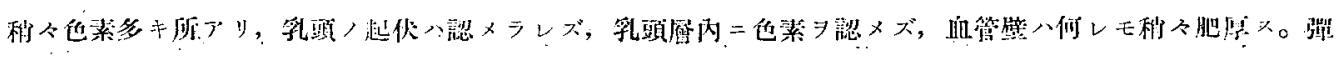

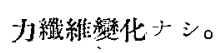

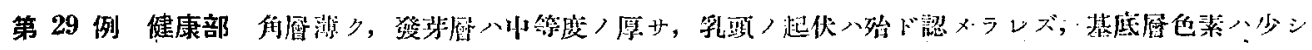

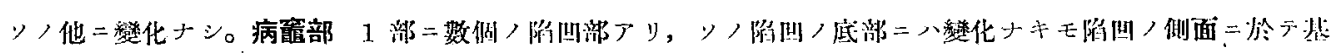

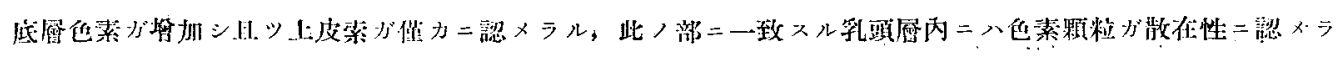

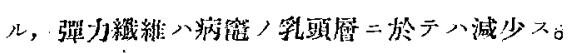

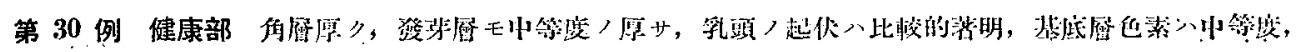

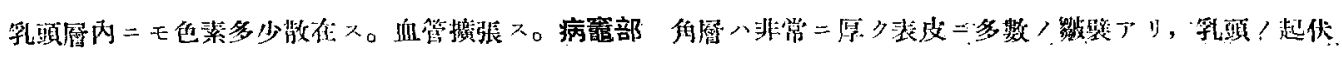

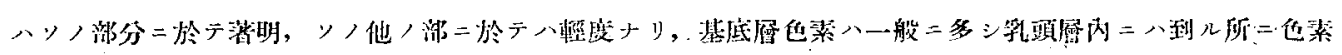

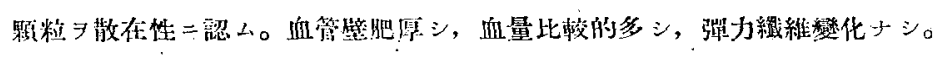

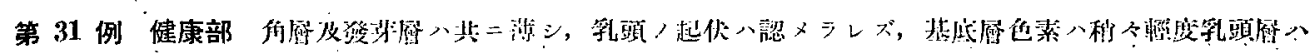




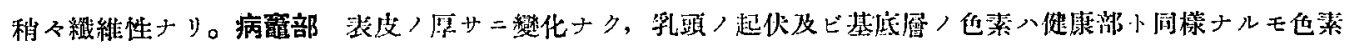

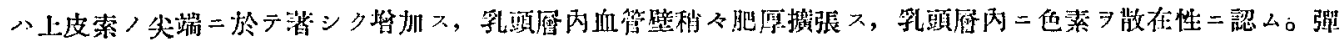
力悢維戀化ナシ。

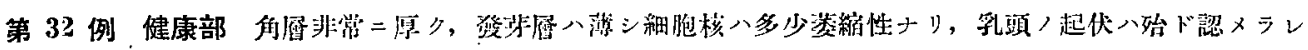

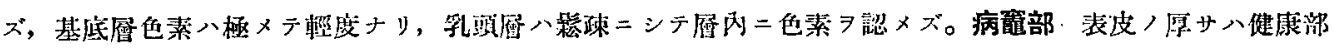

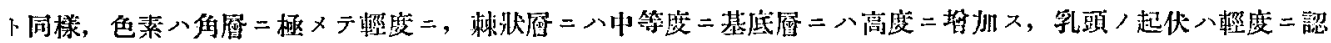

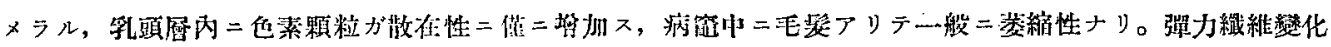
ナシ。

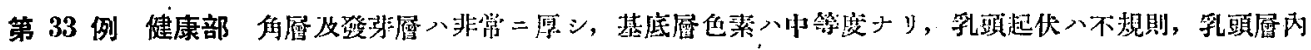

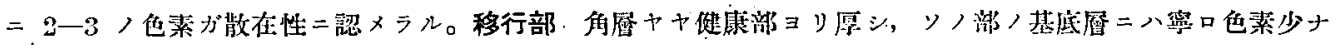

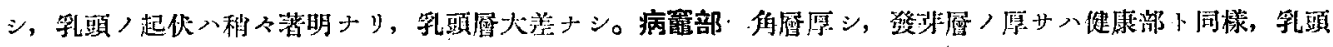

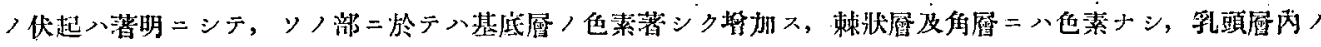

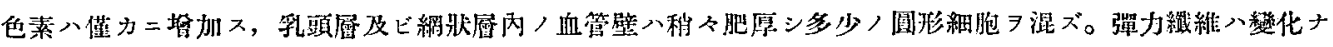
シ。

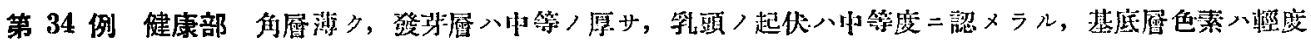

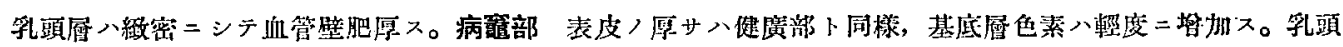

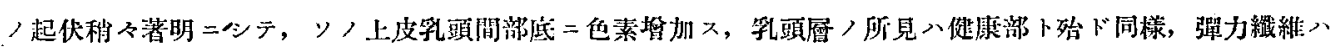
倠化ナシ。

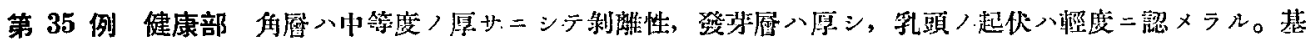

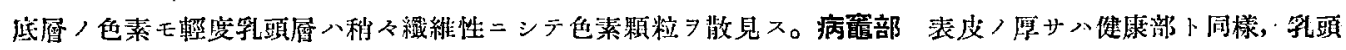

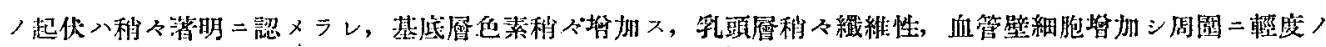

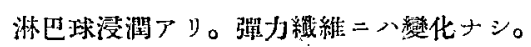

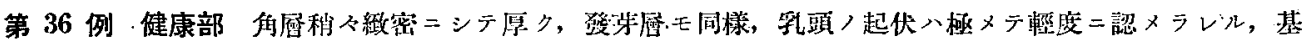

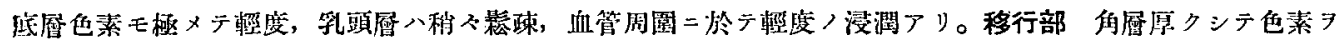

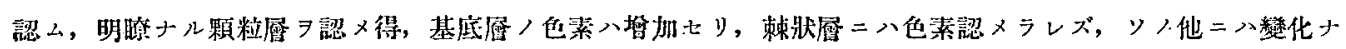

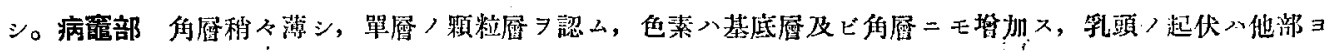

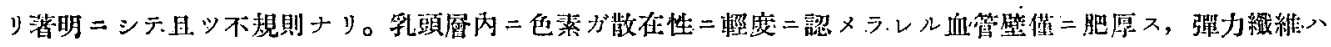
䋶化ナシ。 .

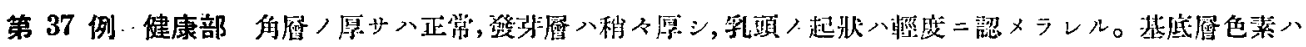

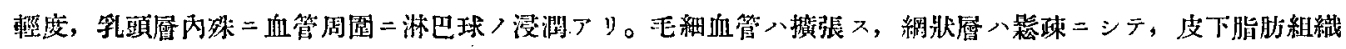

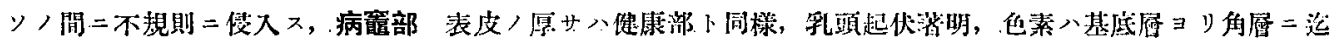

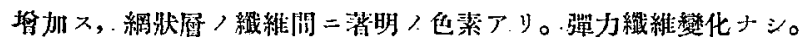

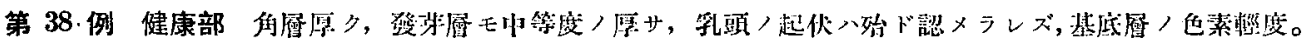

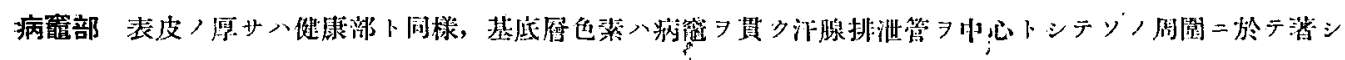

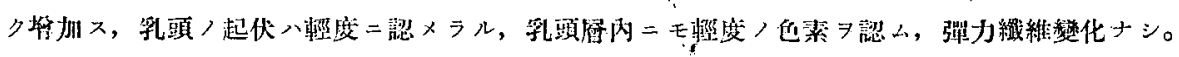




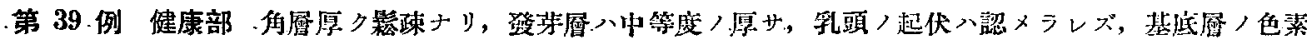

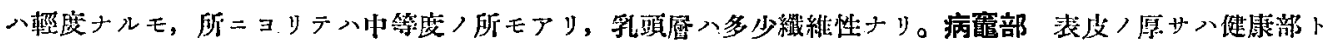

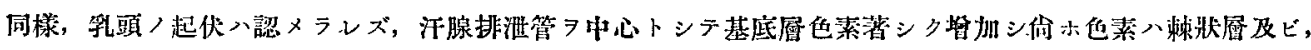

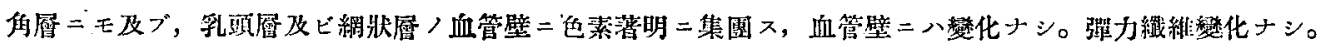

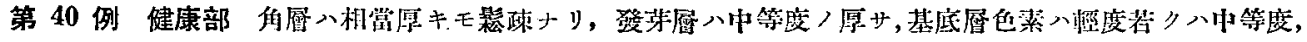

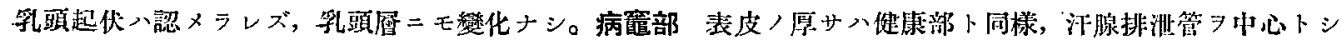

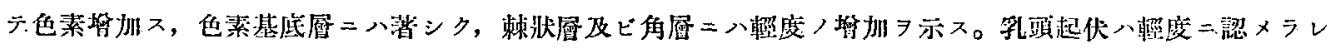

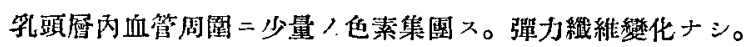

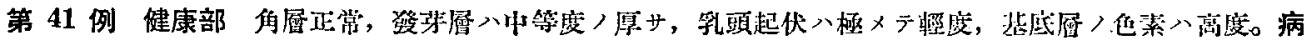

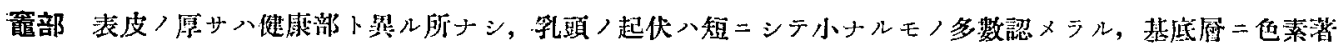

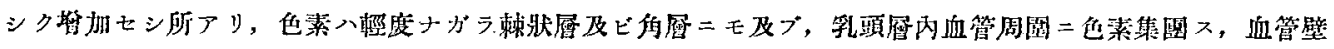

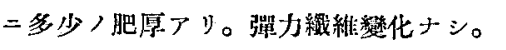

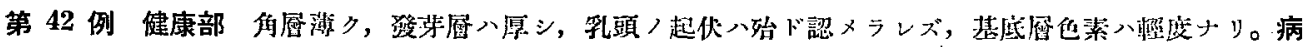

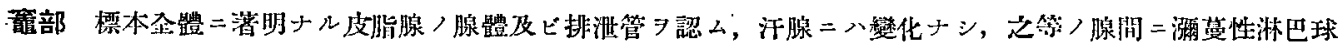

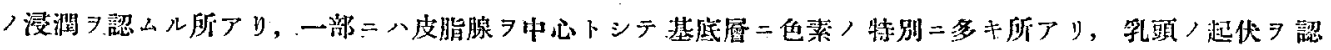

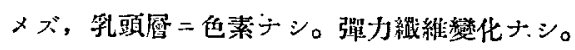

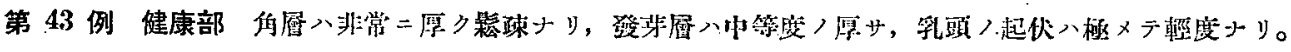

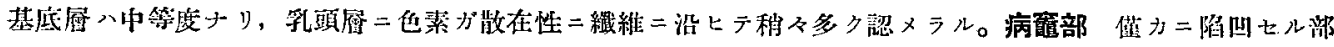

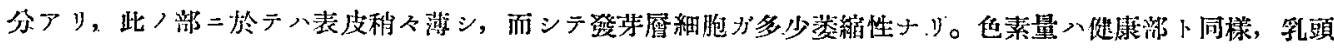

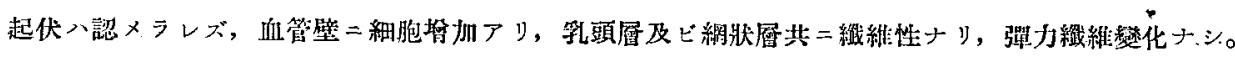

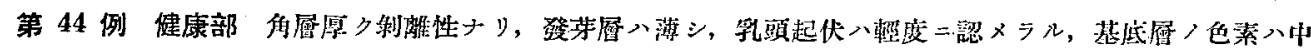

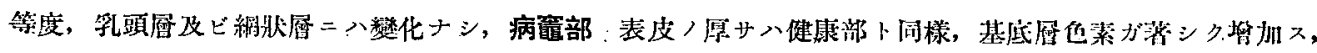

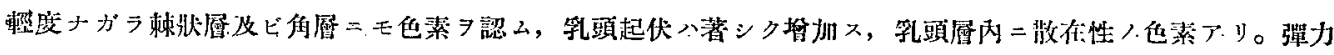
繀維變化ナシ。

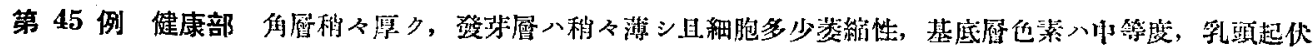

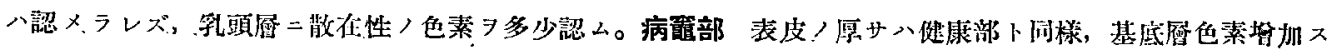

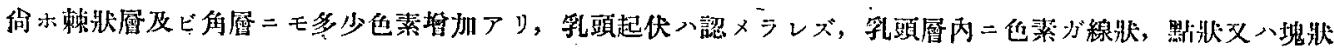

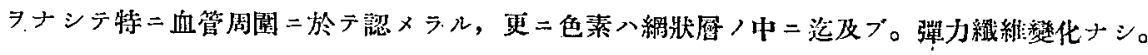

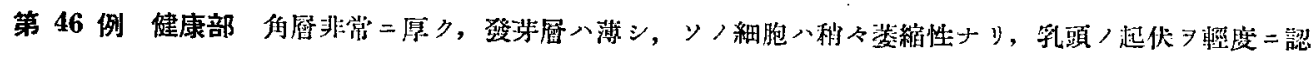

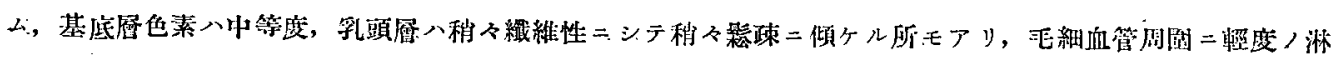

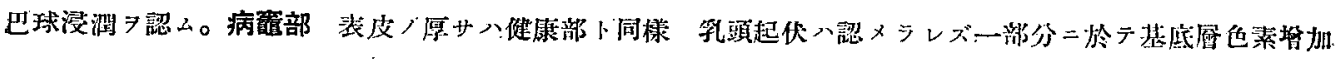

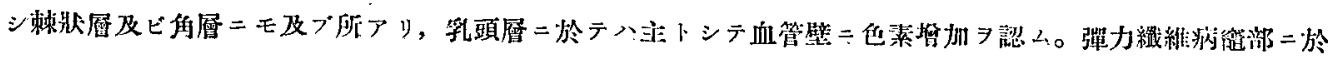

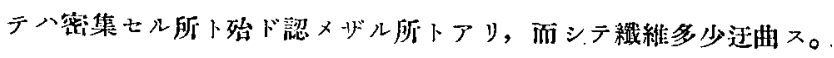

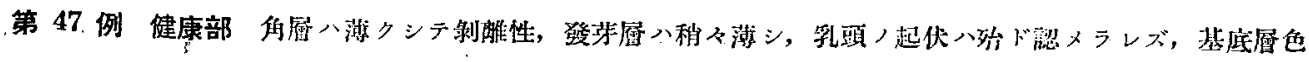

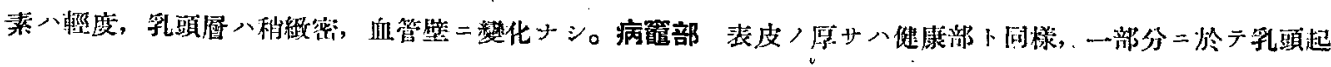




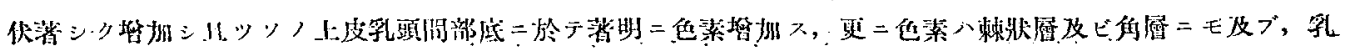

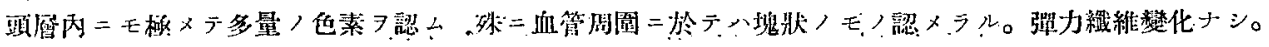

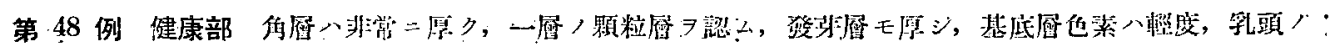

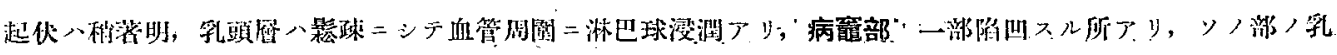

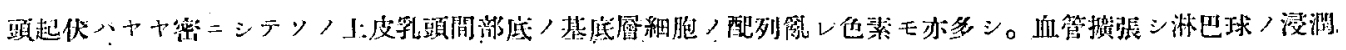

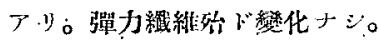

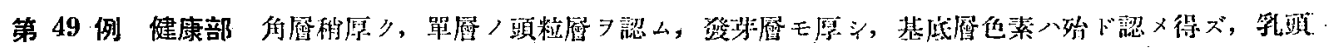

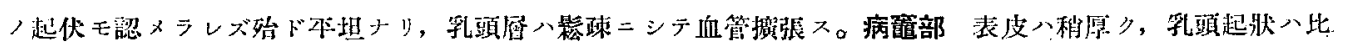

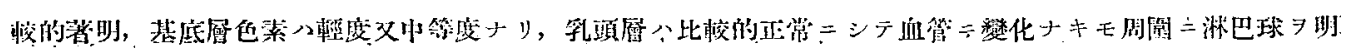

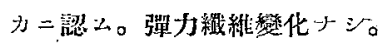

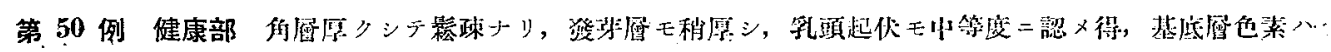

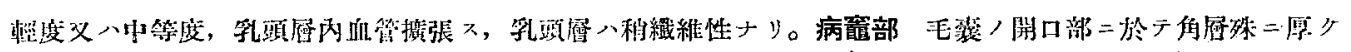

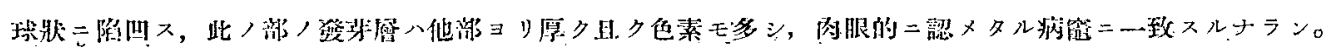

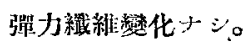

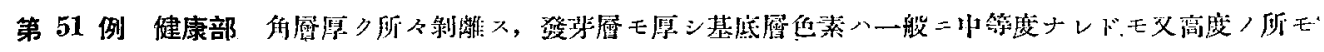

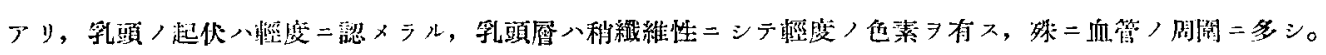

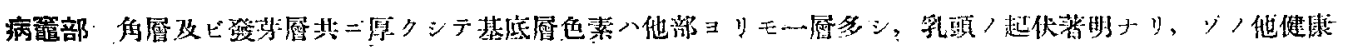

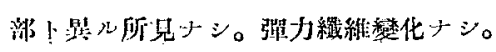

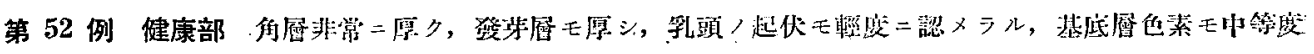

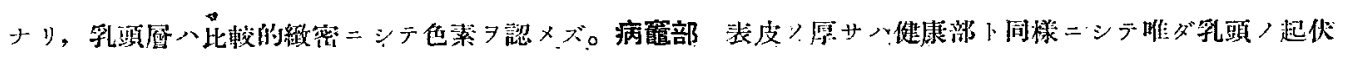

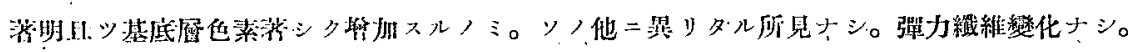

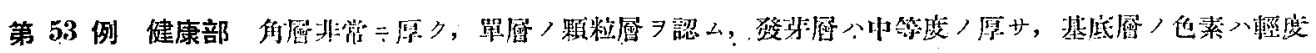

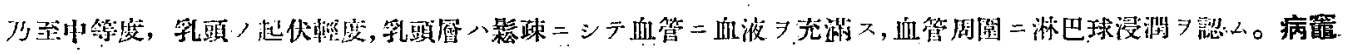

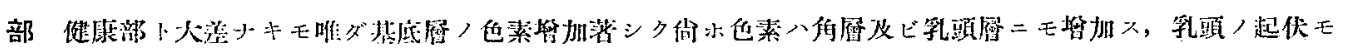

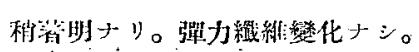

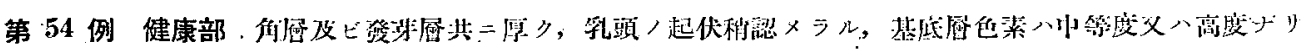

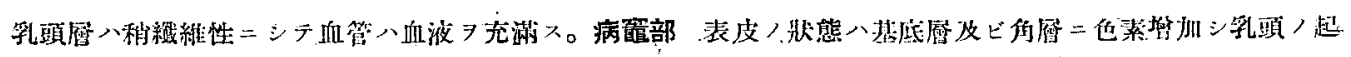

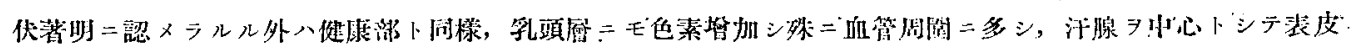

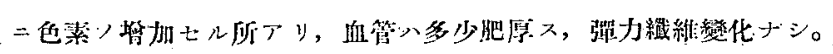

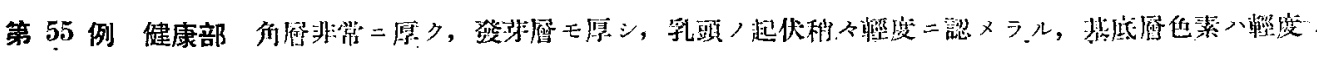

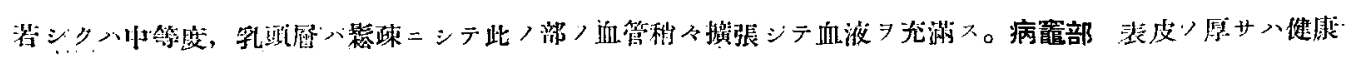

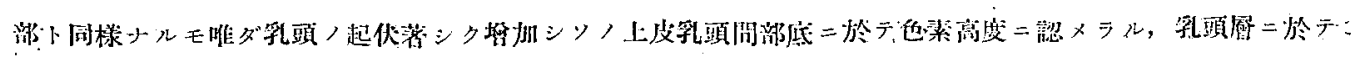

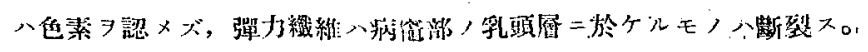

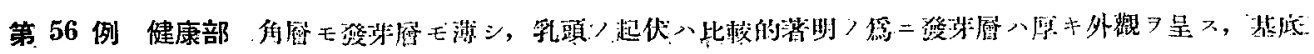

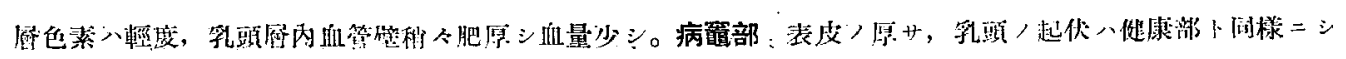




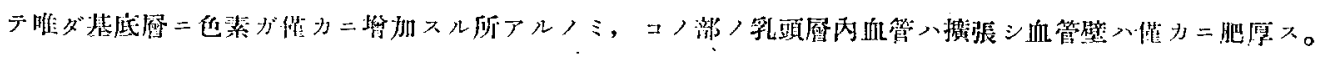
强力繀維變化ナシ。。

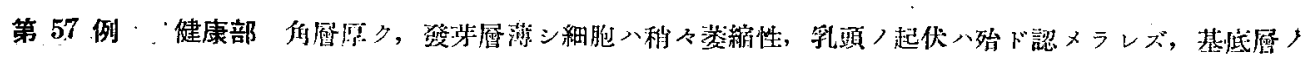

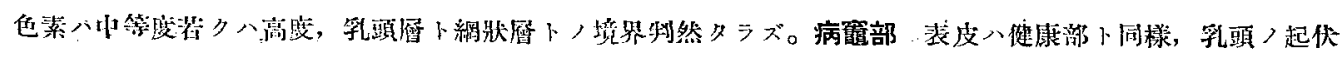

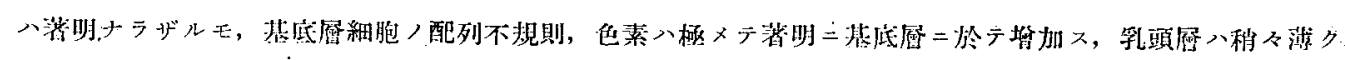

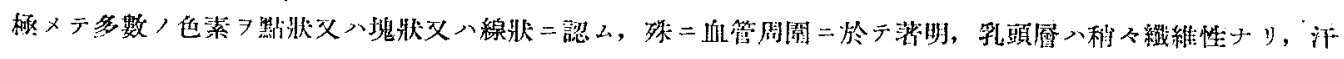

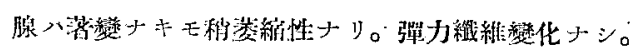

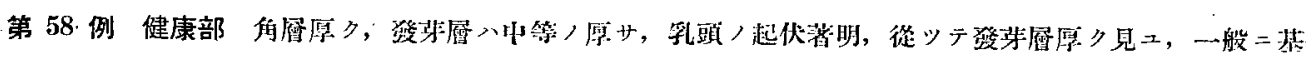

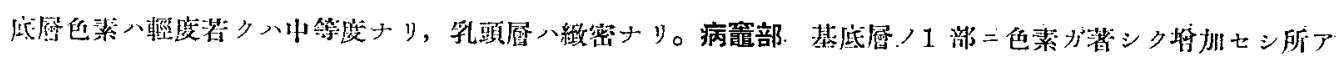

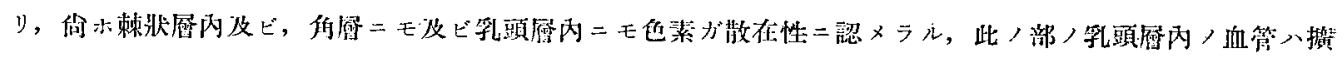

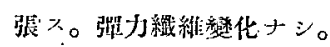

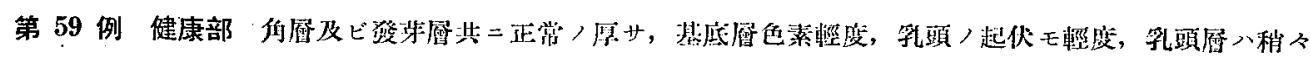

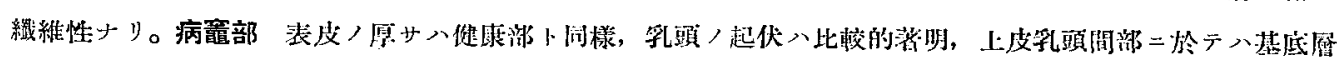

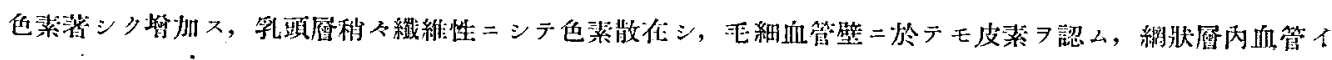

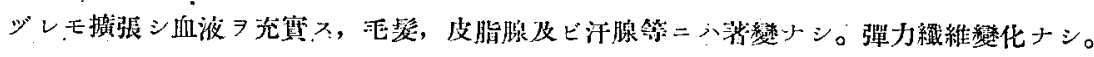

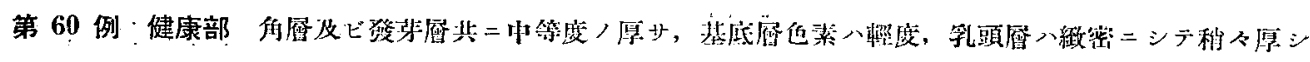

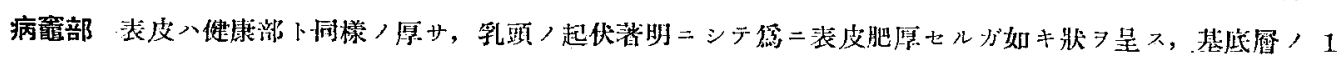

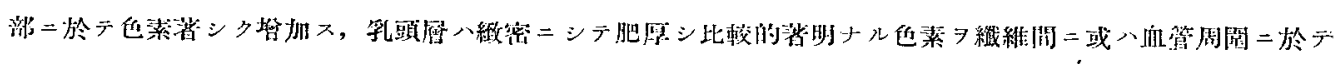

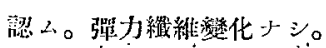

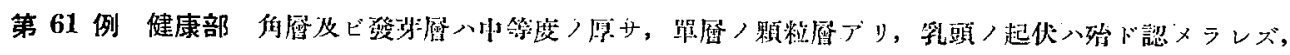

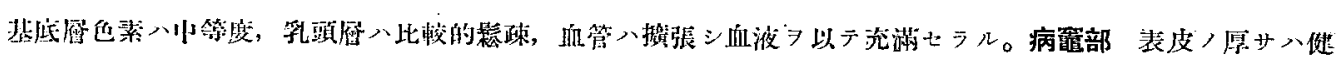

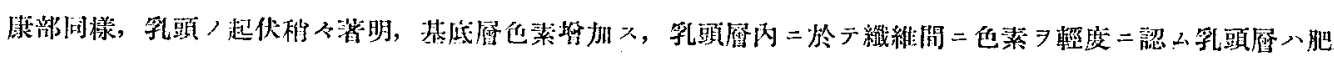

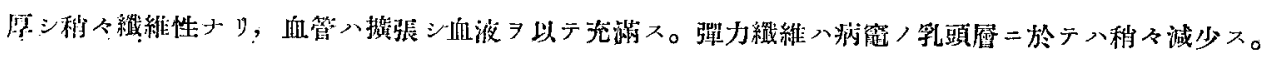

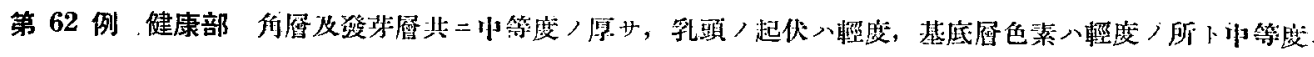

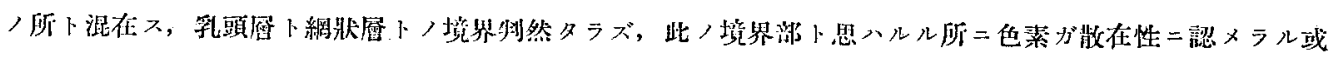

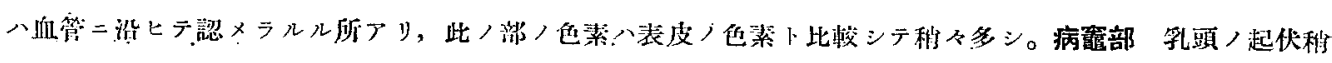

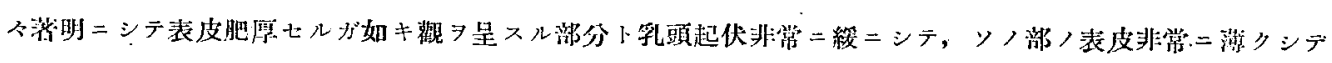

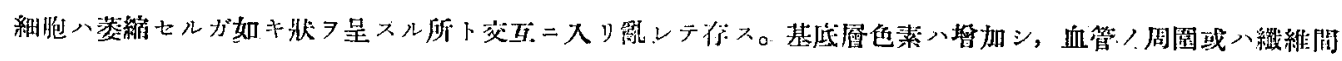

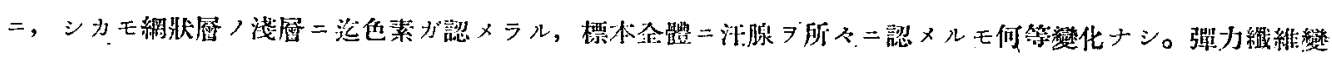
化ナシ。

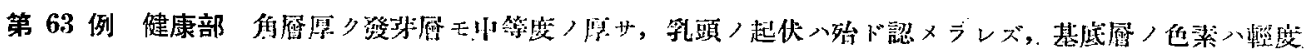

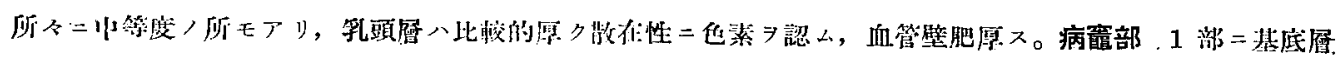

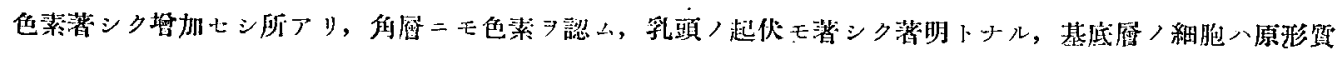

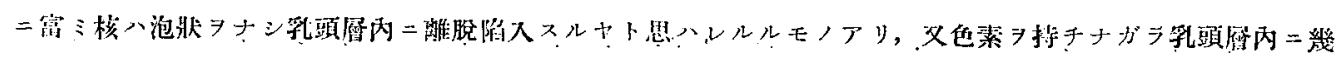

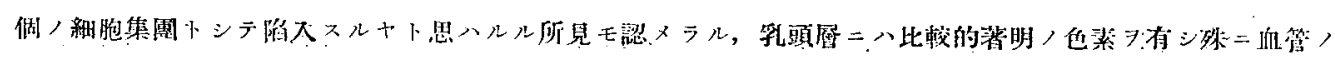




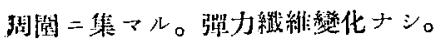

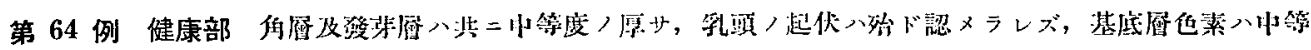

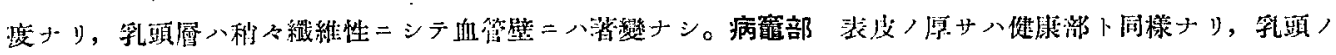

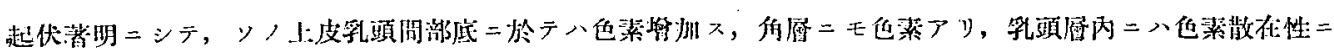

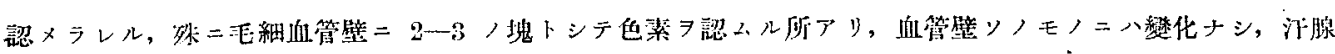

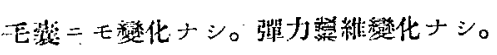

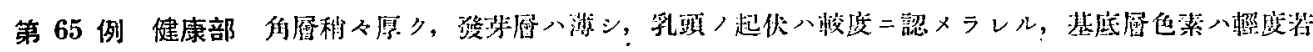

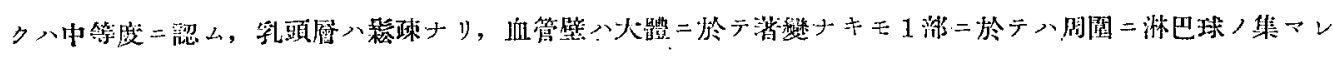

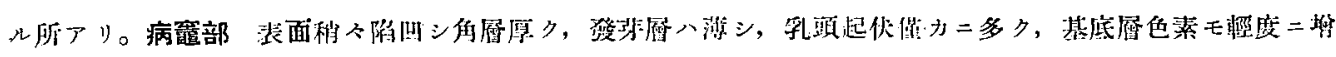

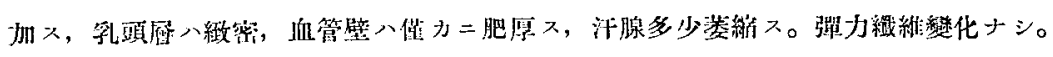

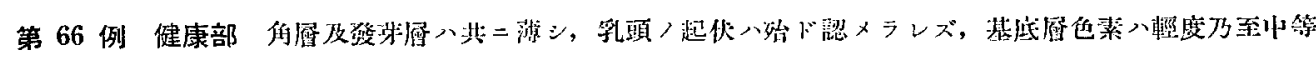

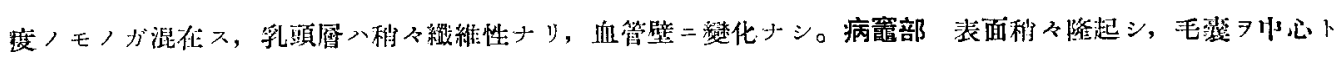

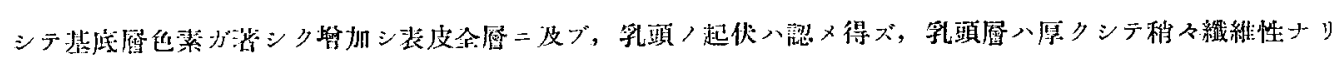

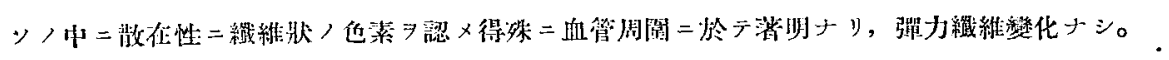

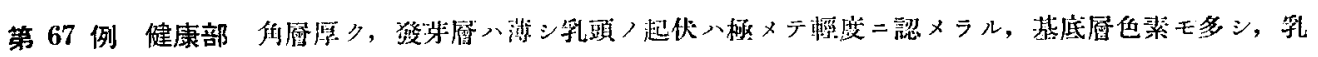

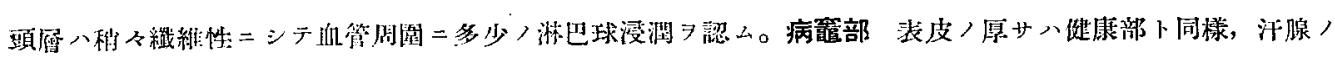

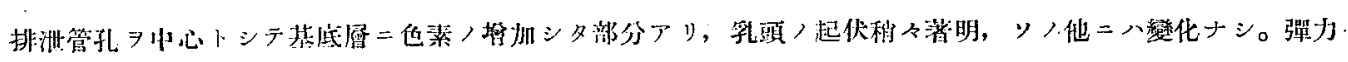
纎維戀化ナシ。

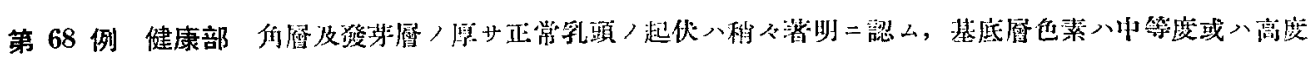

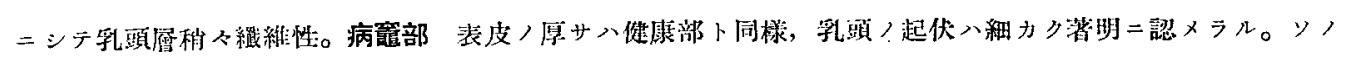

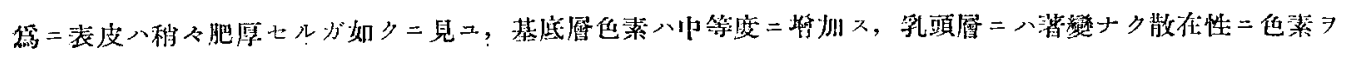

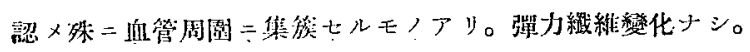

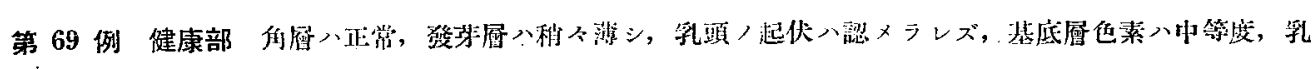

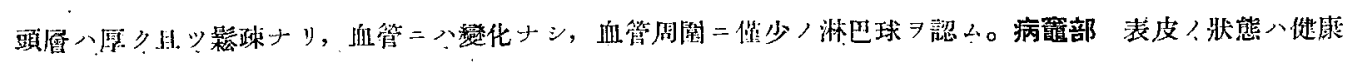

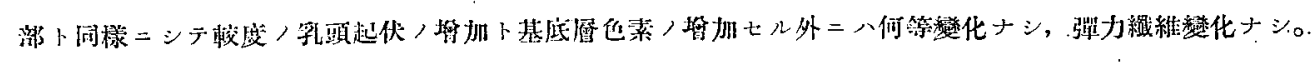

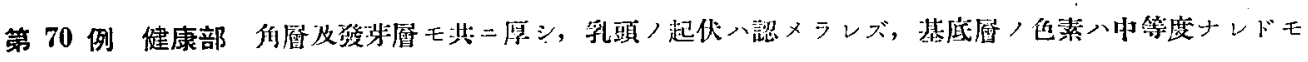

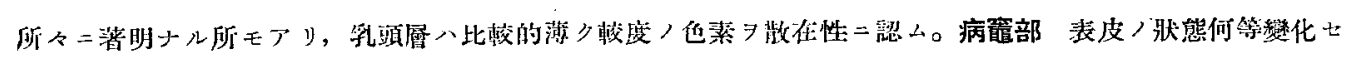

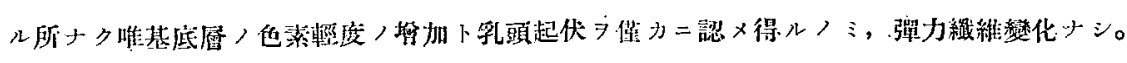

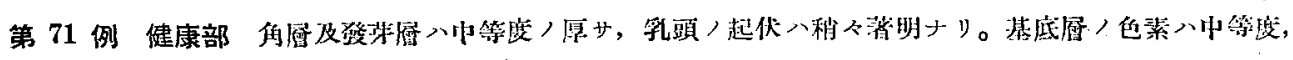

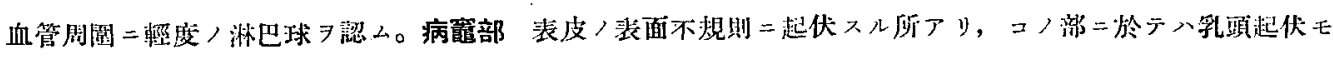

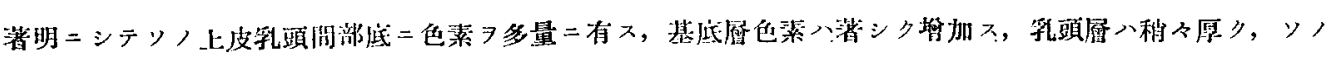

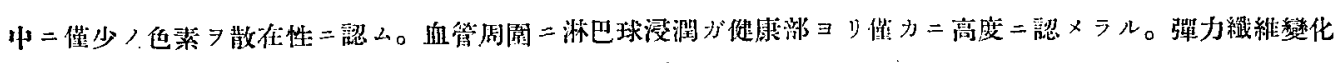
ナシ。

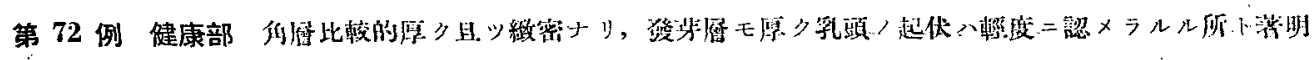

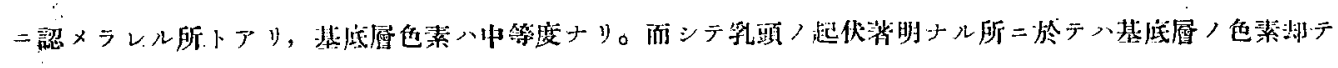




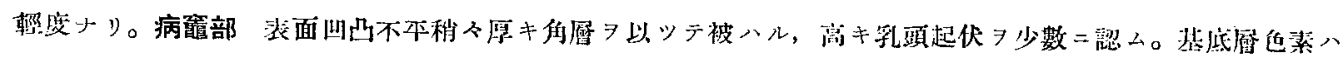

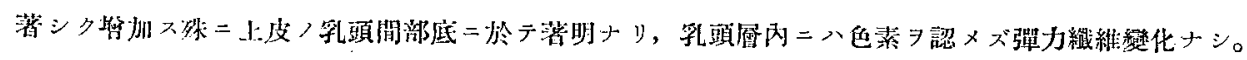

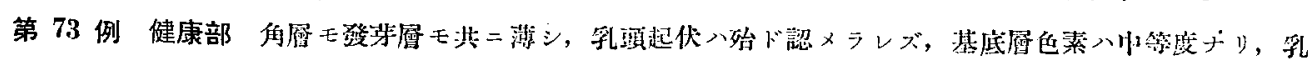

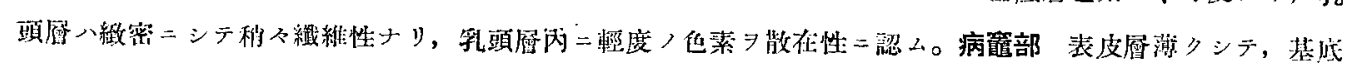

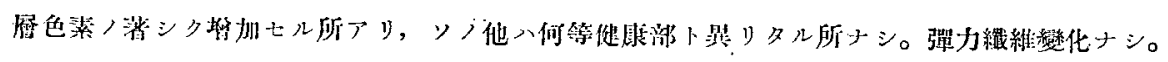

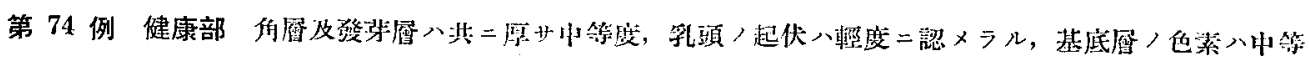

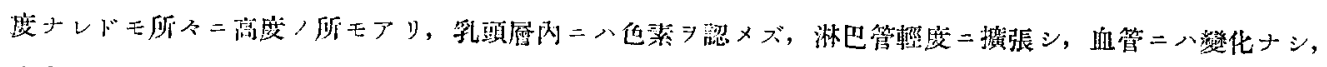

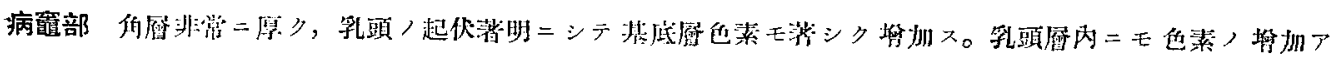

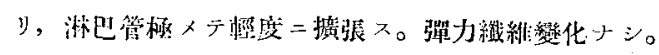

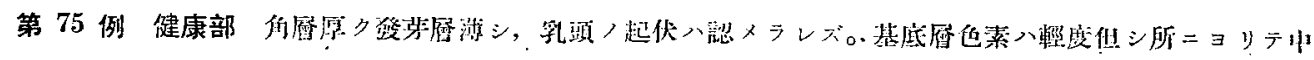

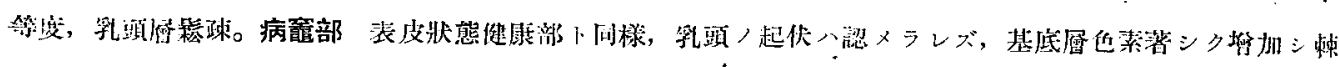

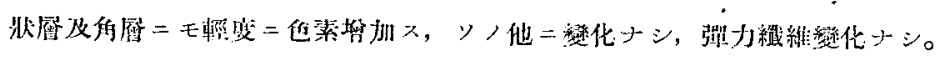

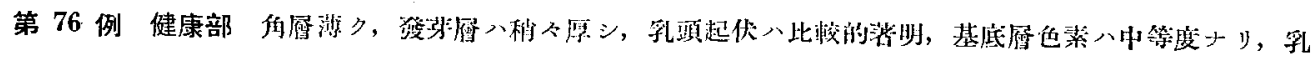

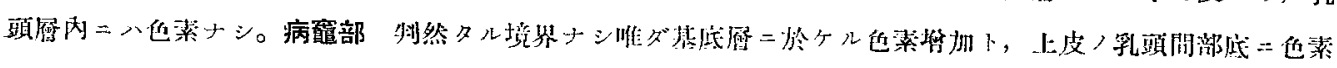

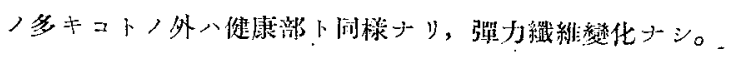

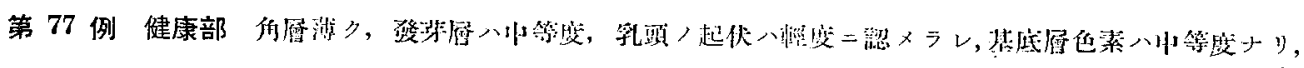

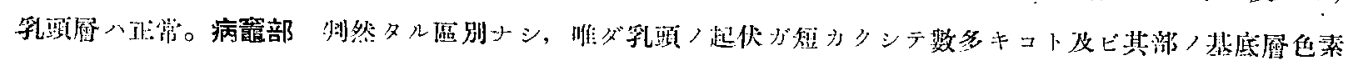

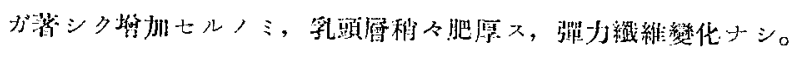

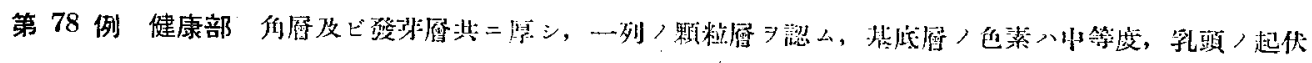

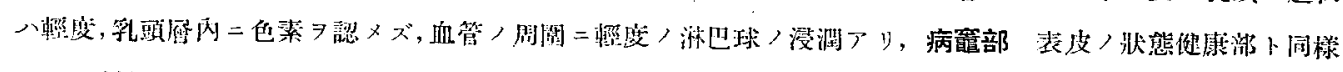

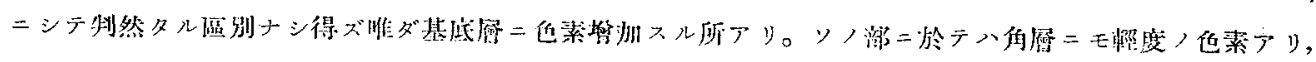

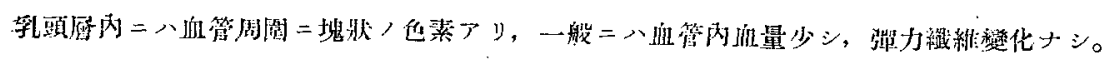

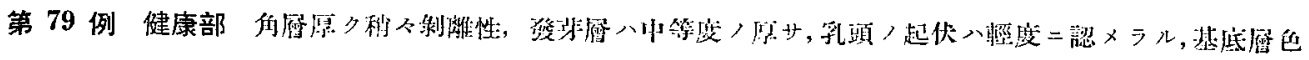

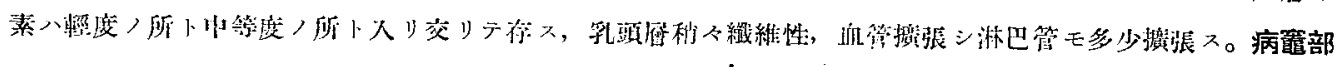

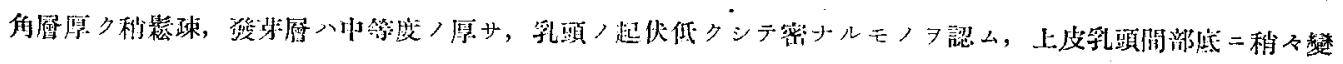

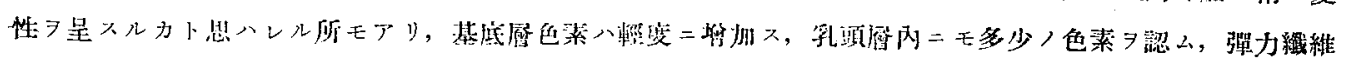
變化ナシ

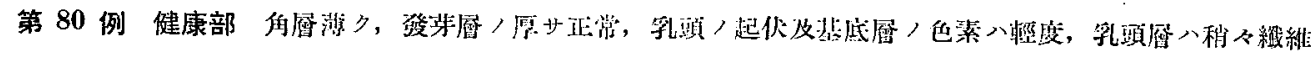

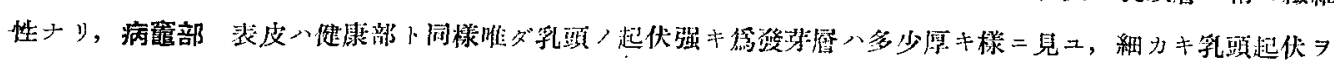

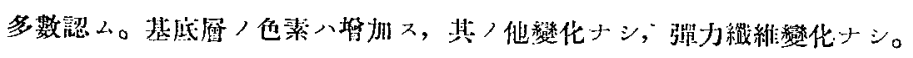

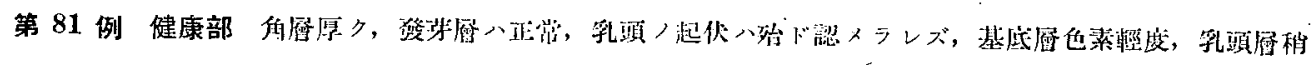

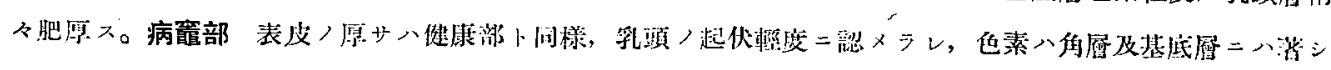

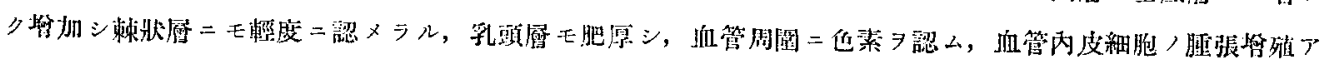

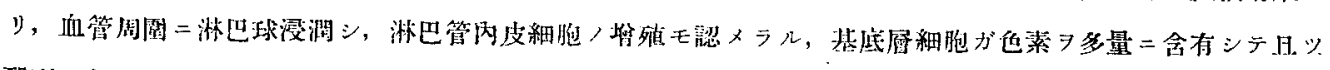

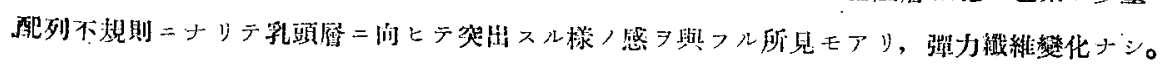




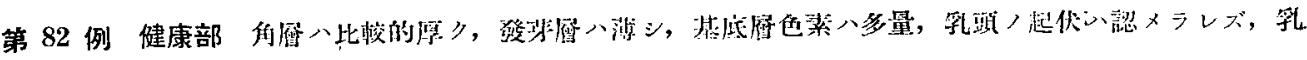

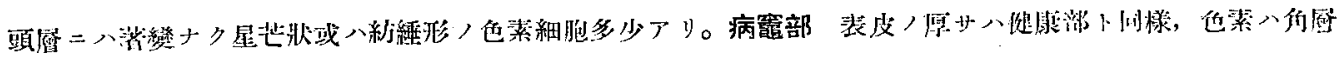

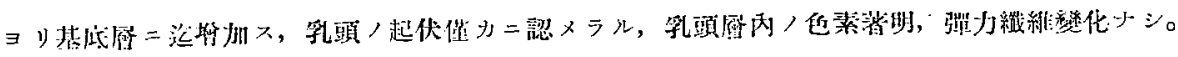

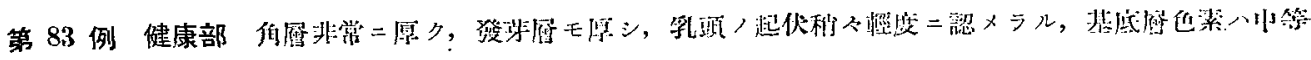

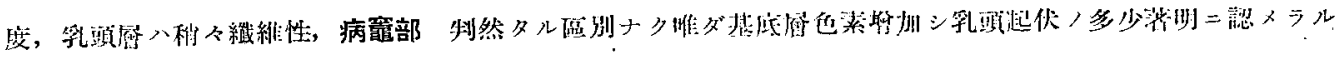

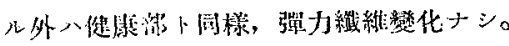

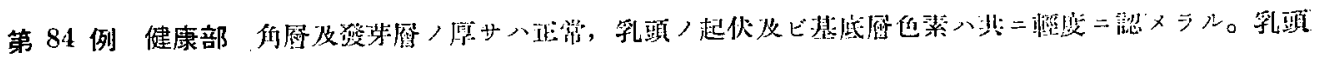

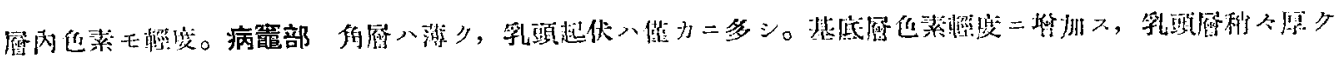

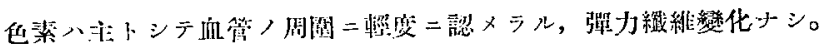

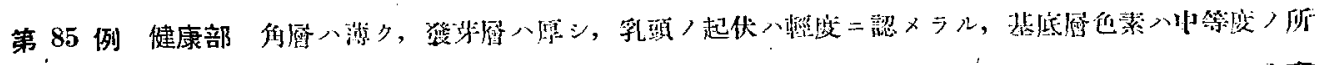

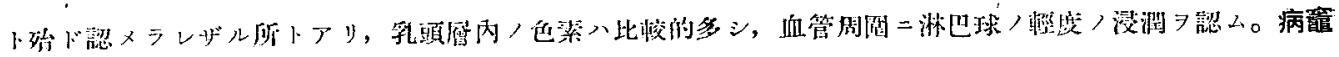

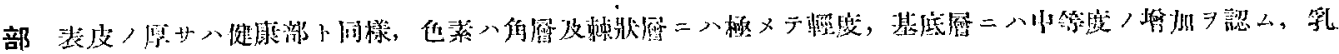

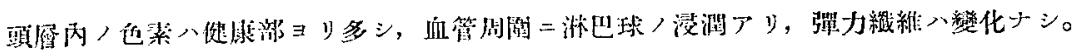

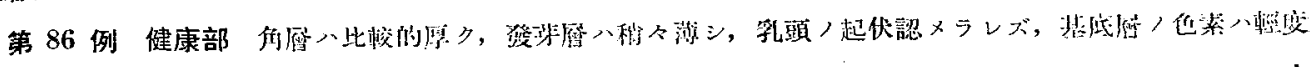

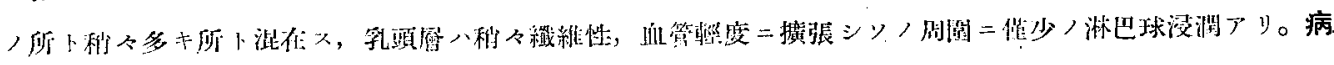

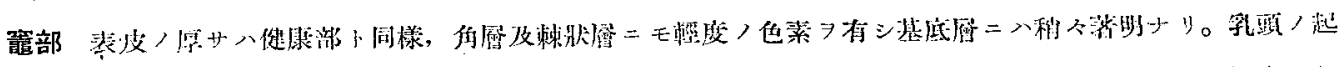

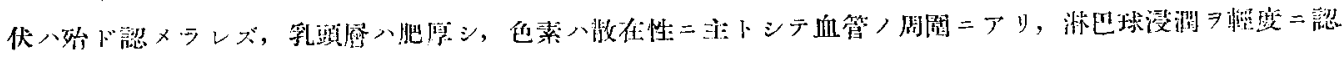

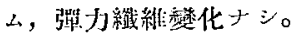

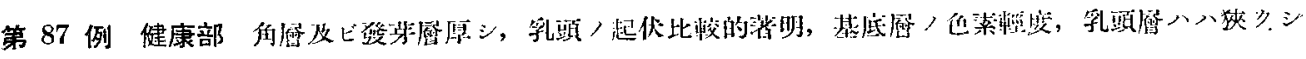

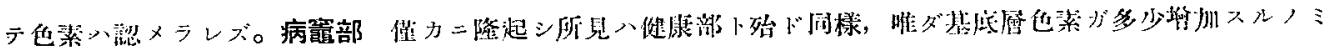

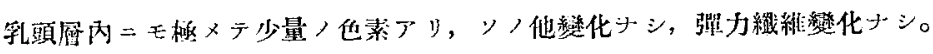

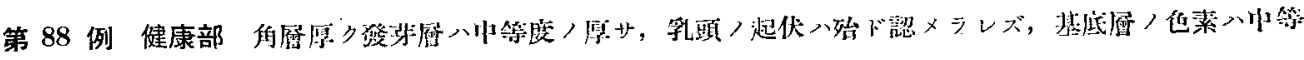

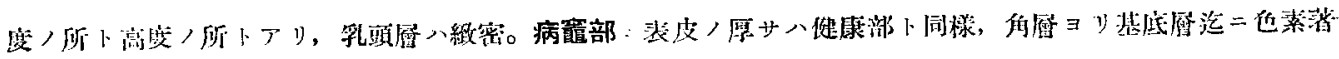

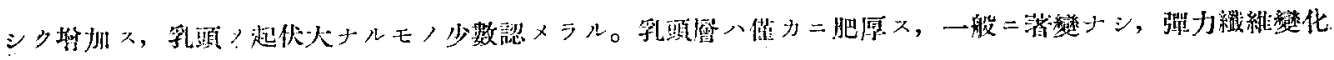
ナリ。

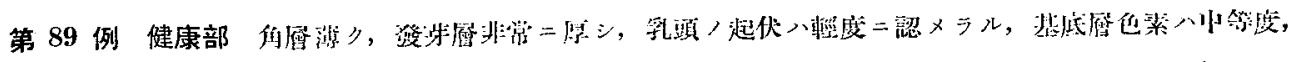

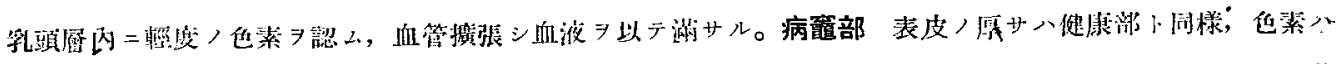

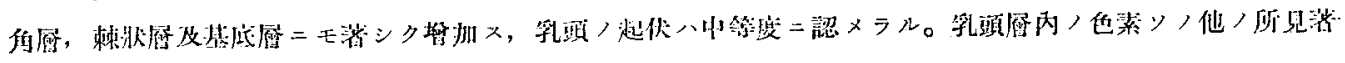

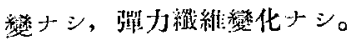

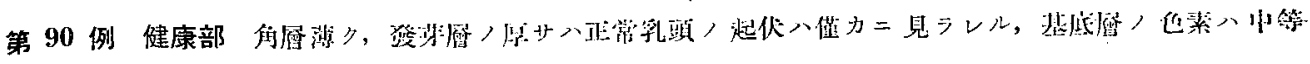

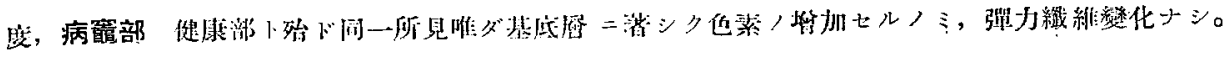

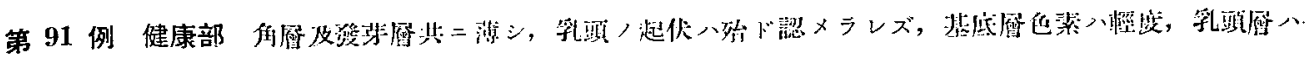

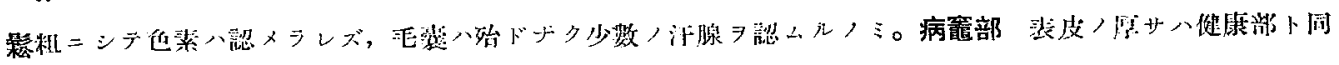

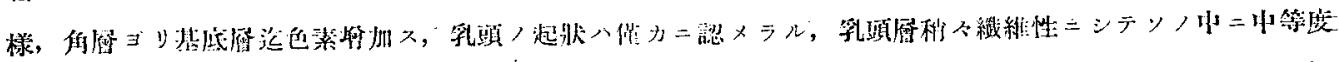

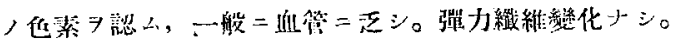




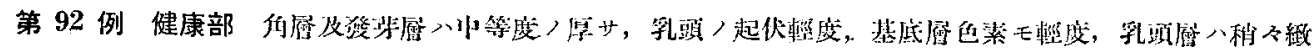

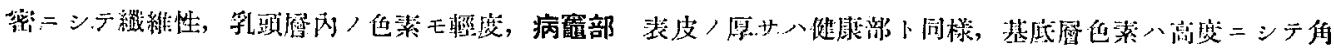

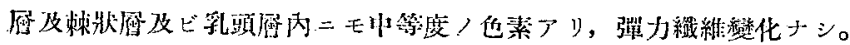

\section{3. 第三 型}

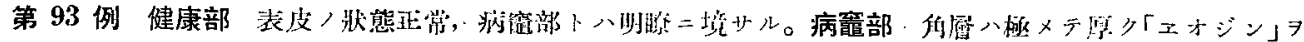

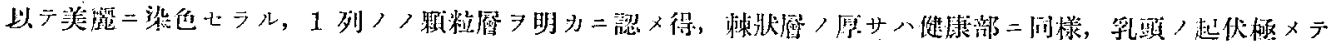

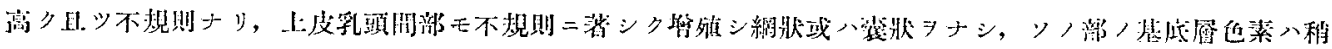

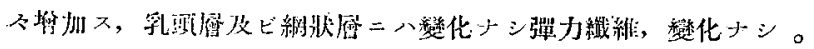

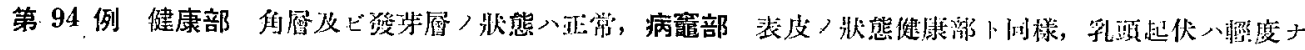

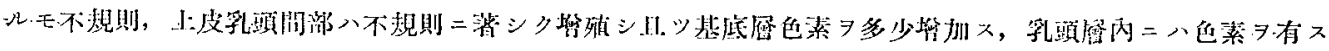

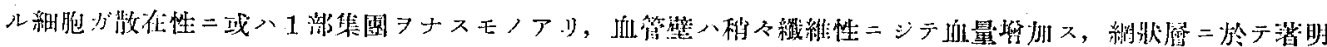

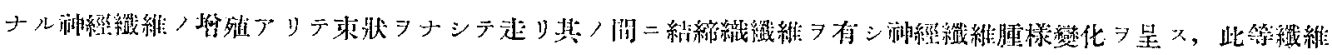

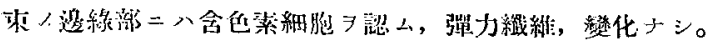

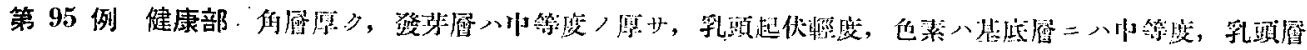

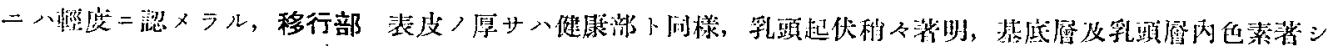

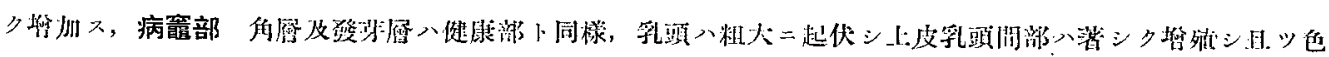

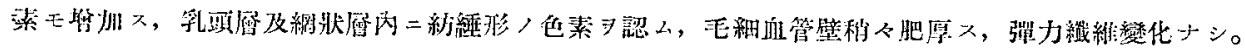

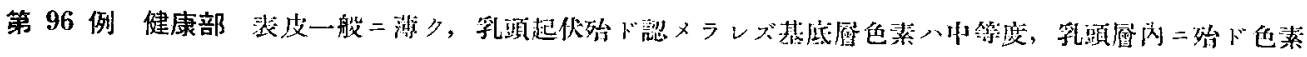

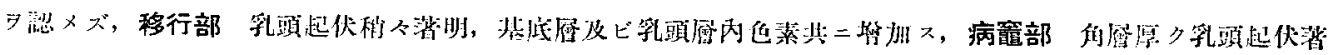

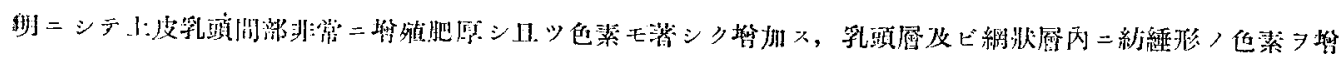

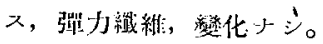

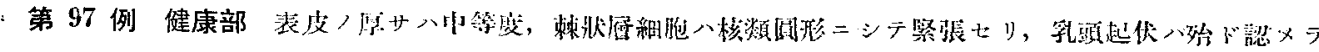

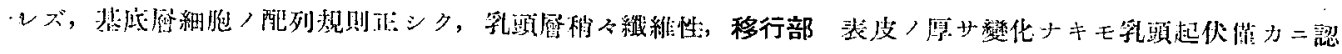

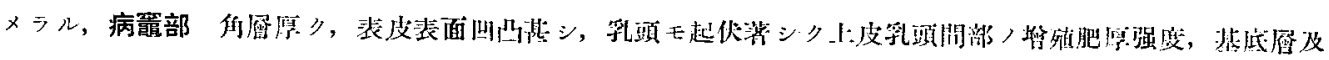

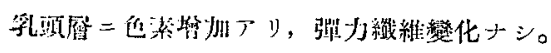

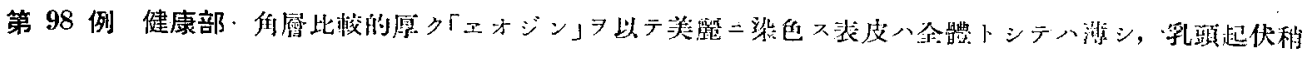

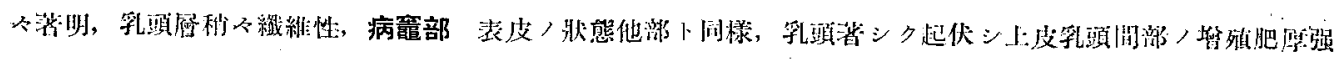

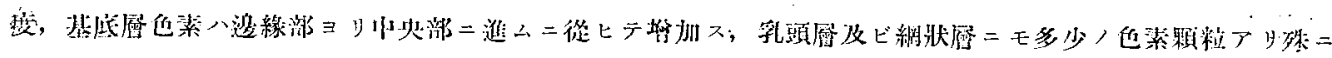

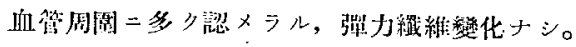

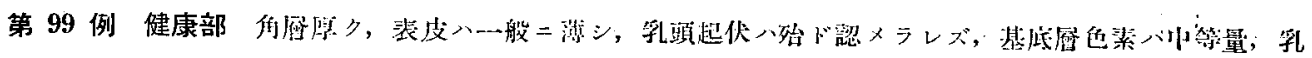

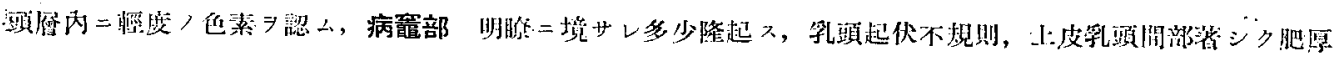

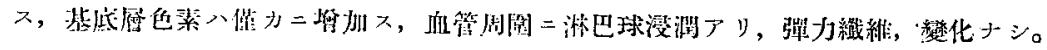

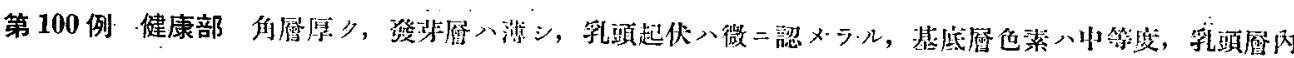

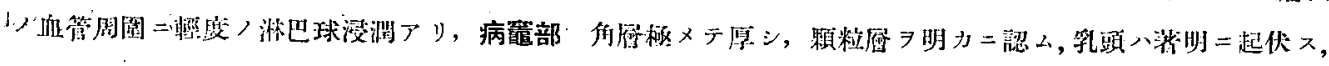

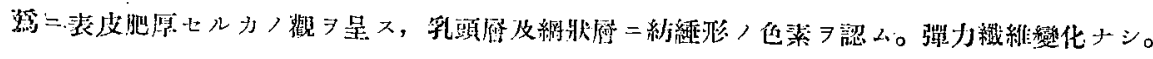




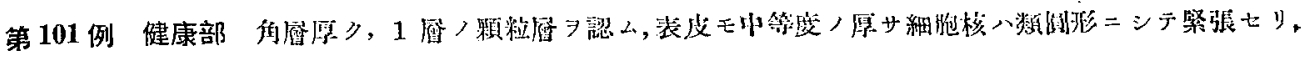

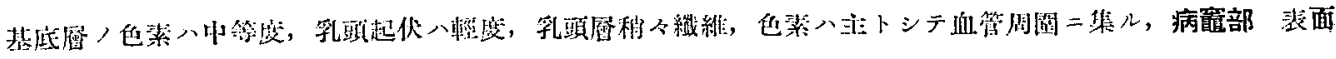

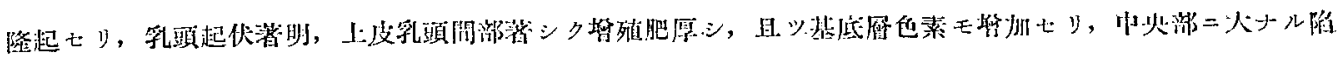

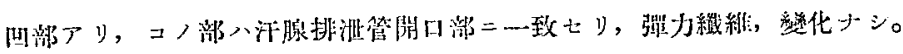

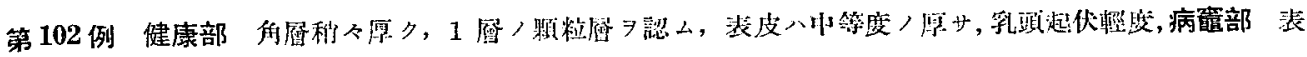

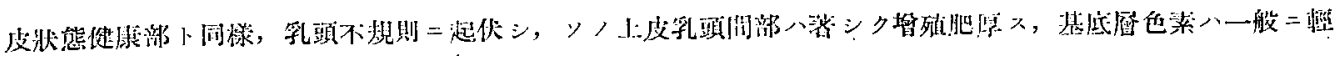

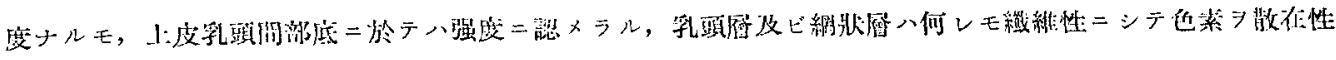

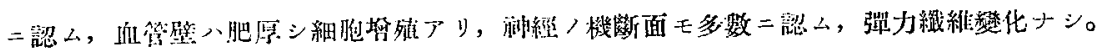

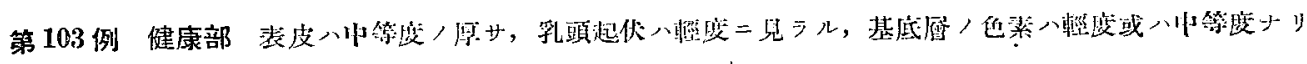

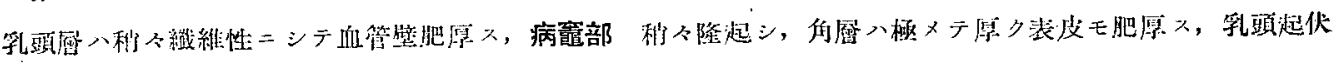

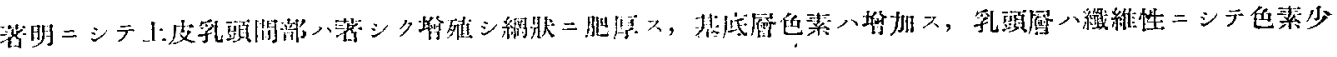
シ，彈力綘維，䋖化ナシ。

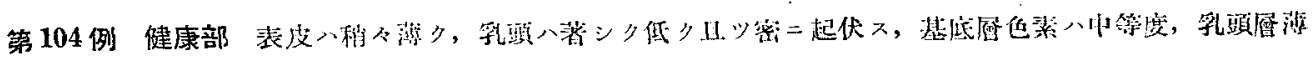

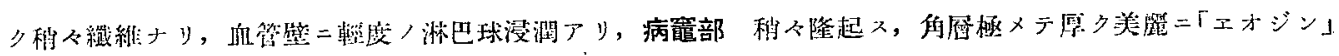

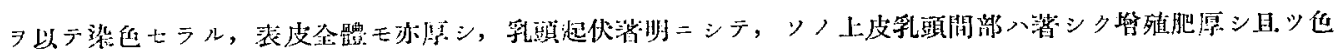

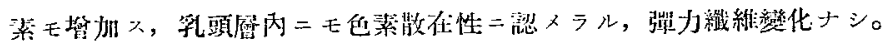

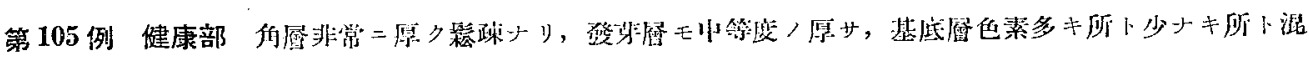

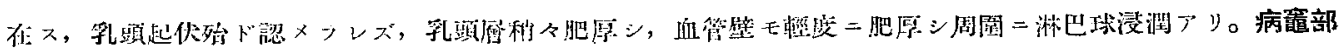

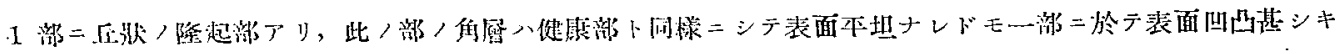

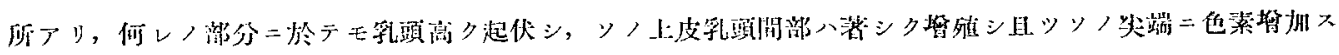

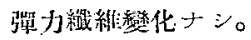

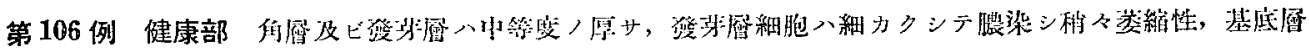

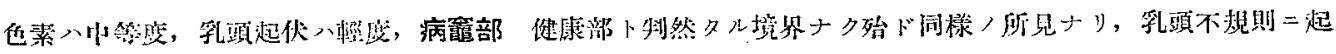

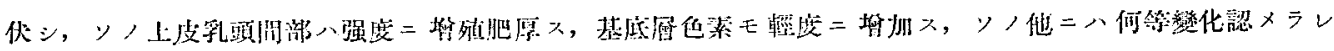

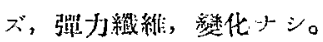

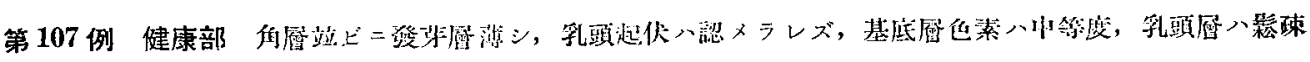

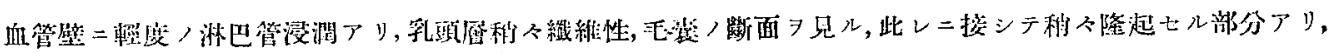

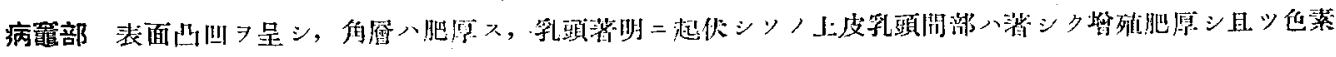

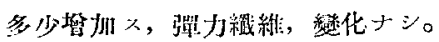

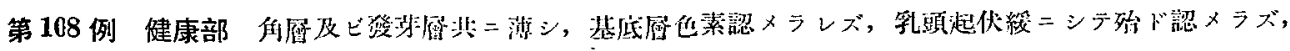

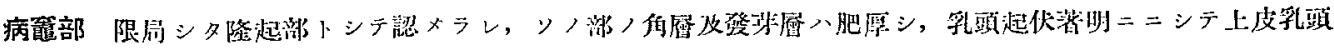

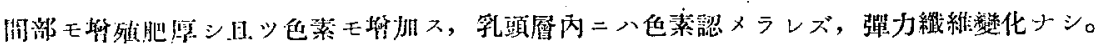

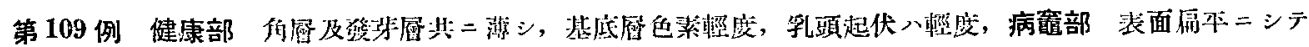

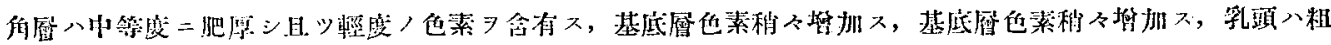

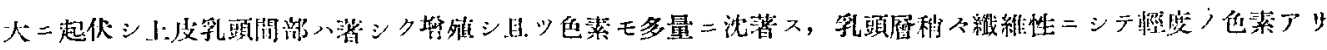


弾力禈維戀化ナシ。

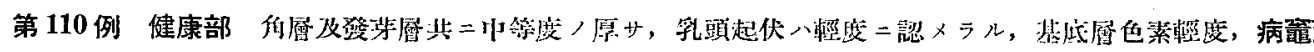

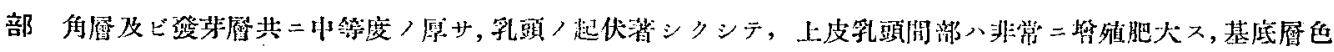

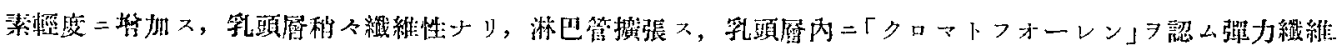
策化ナシ。

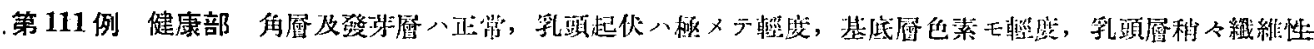

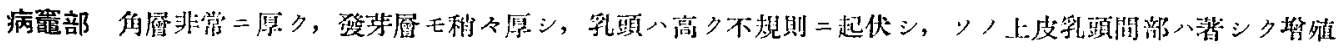

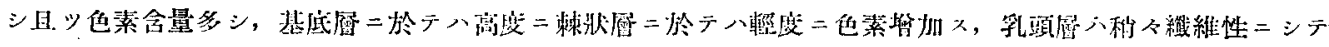

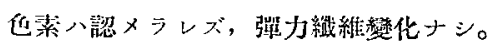

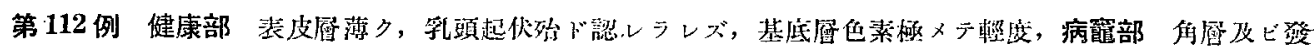

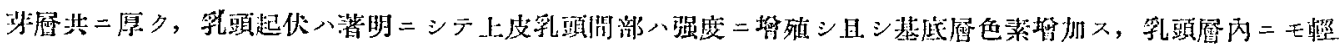

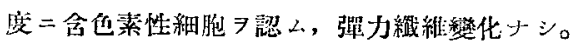

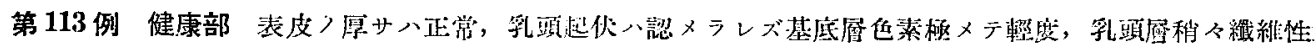

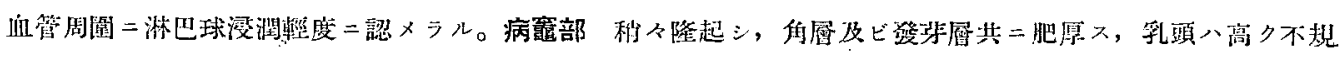

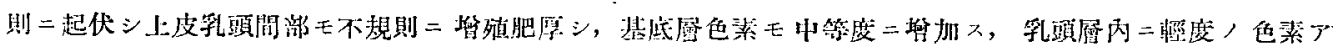

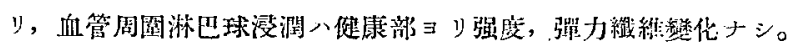

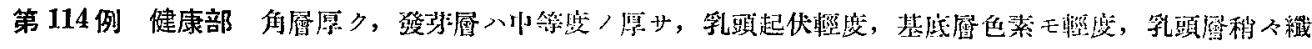

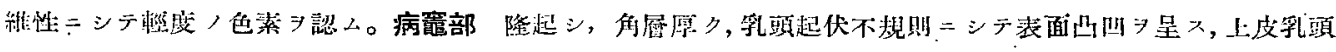

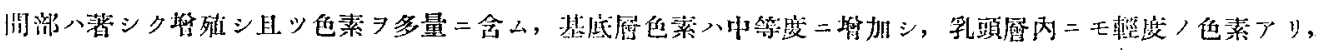

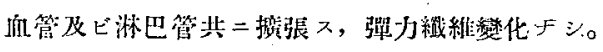

\section{4. 第 四 型}

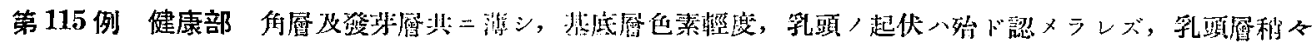

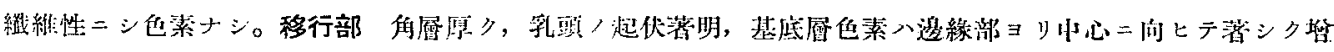

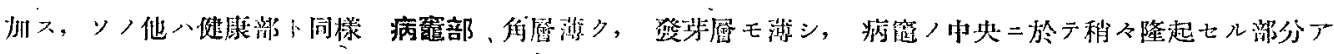

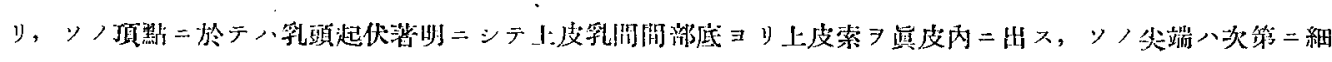

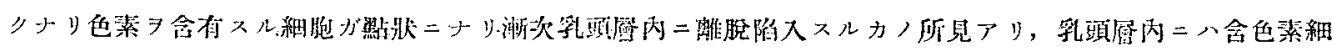

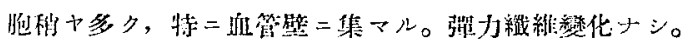

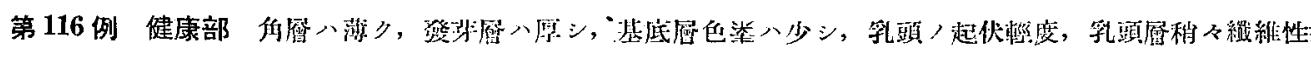

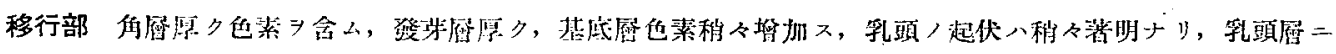

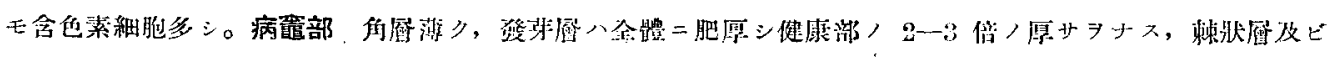

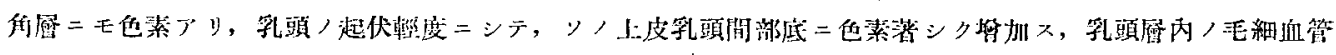

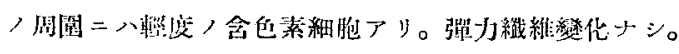

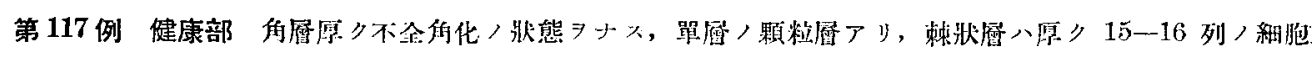

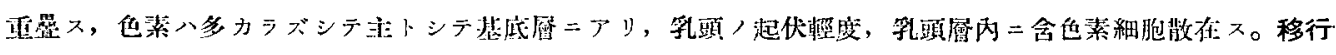

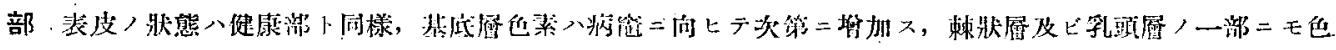




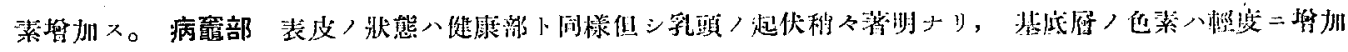

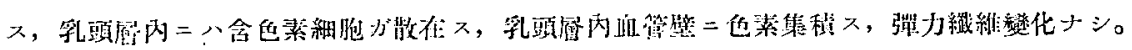

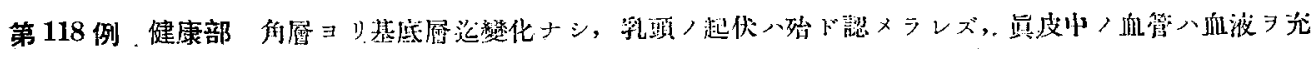

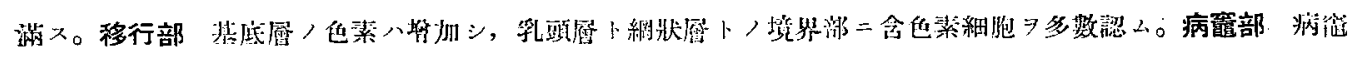

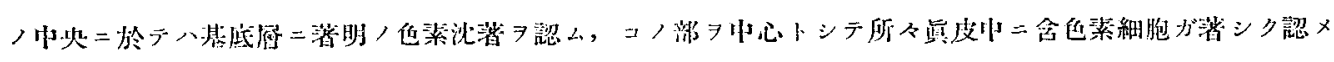

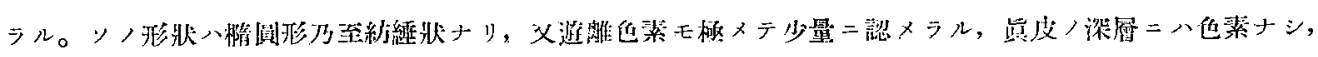

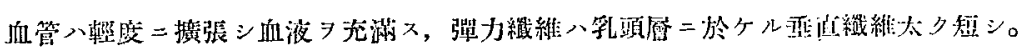

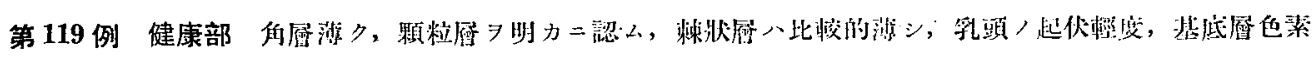

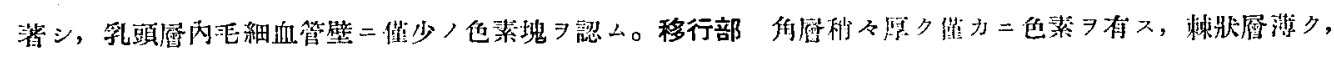

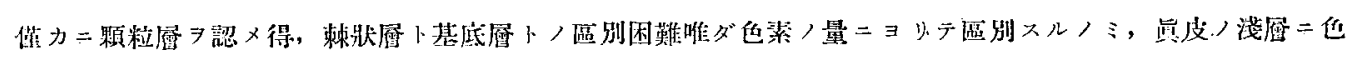

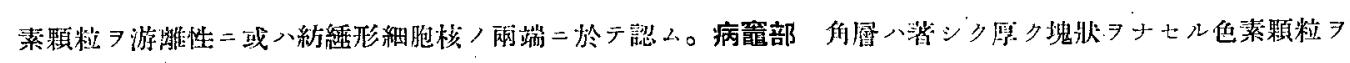

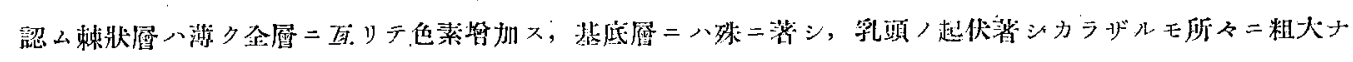

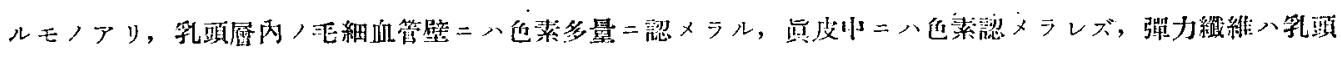

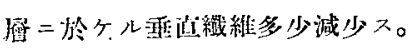

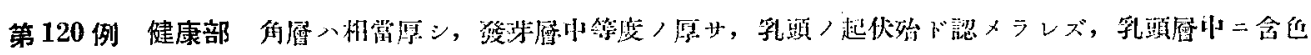

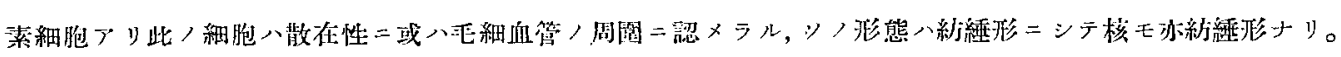

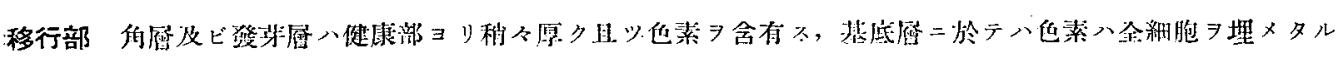

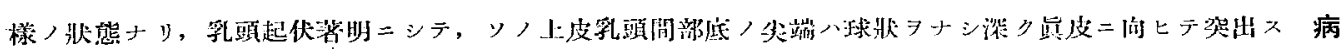

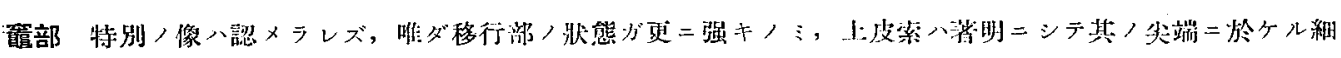

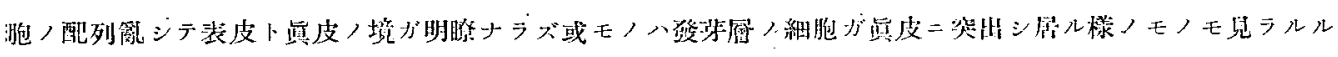

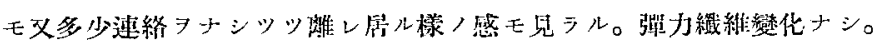

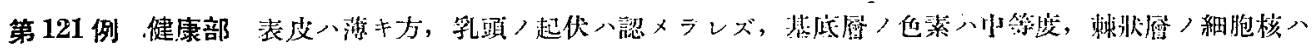

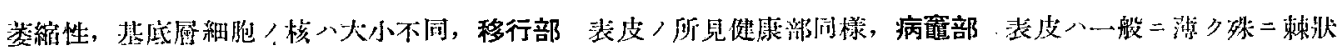

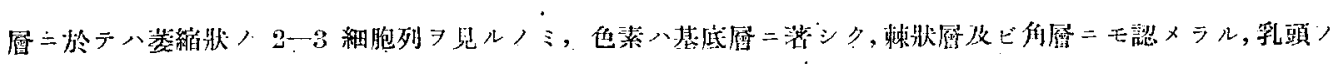

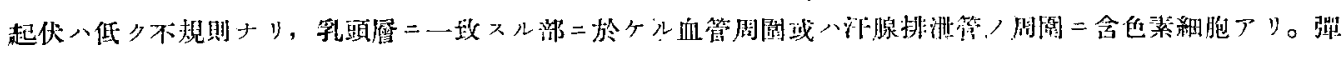
力䄉䊒綎化ナシ。

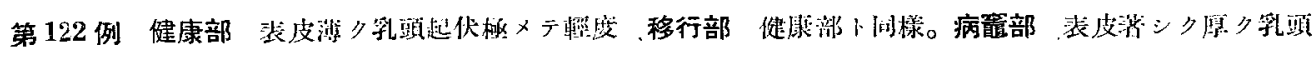

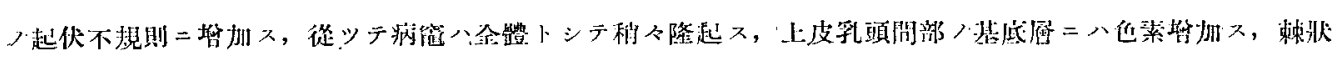

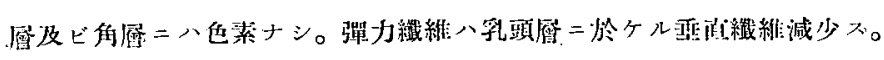

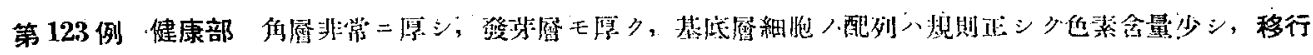

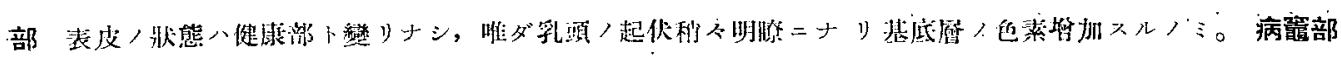

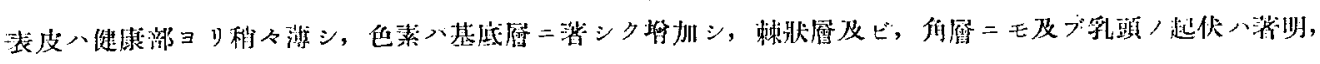

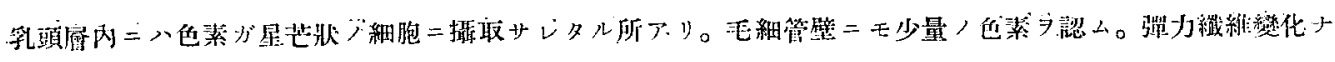
シ。

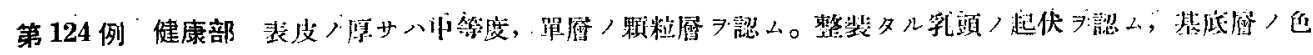




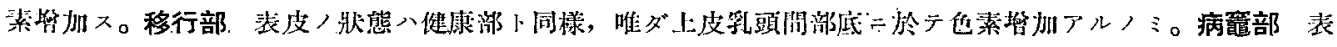

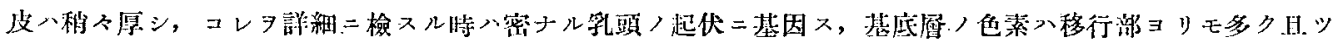

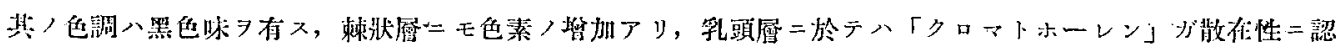

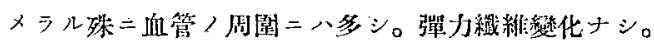

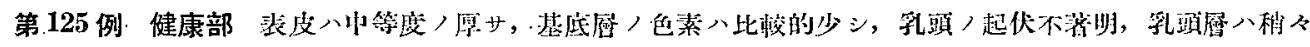

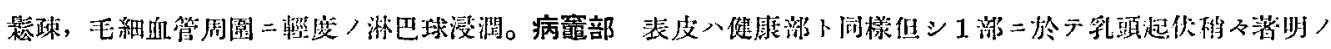

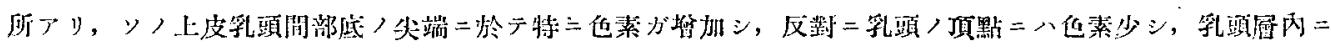

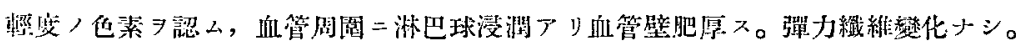

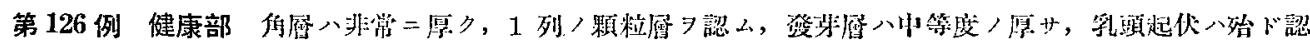

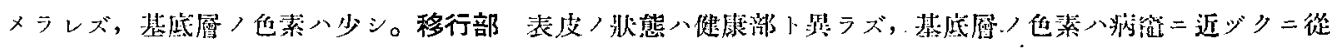

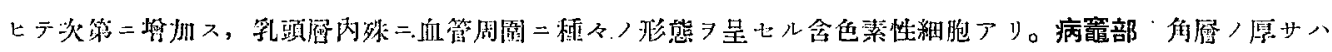

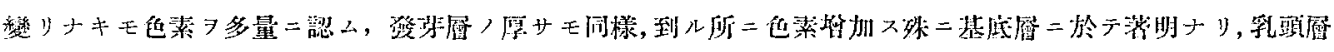

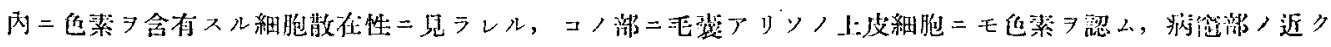

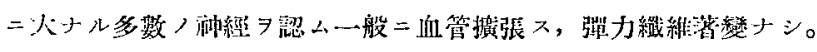

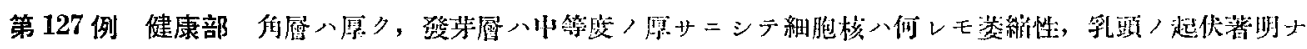

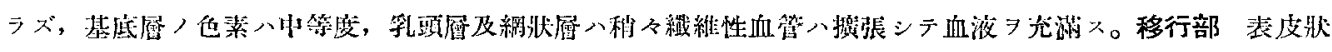

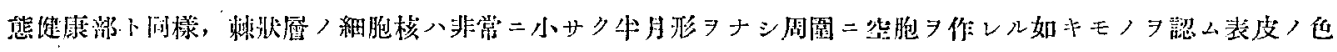

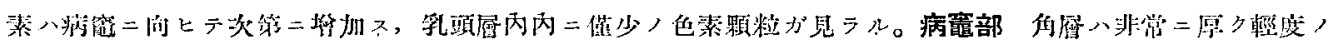

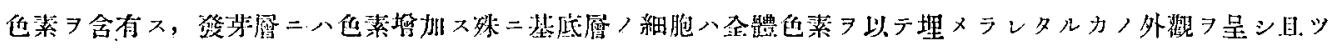

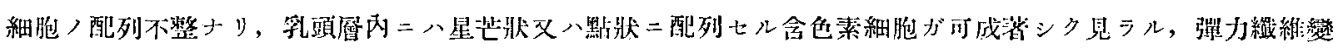
化ナシ。

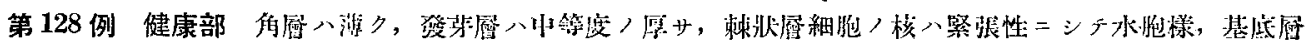

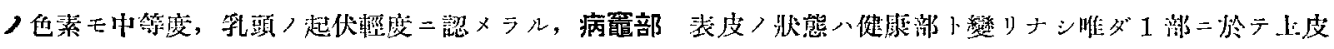

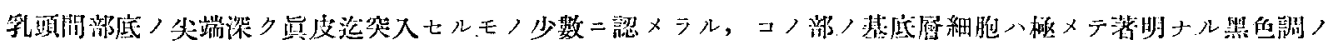

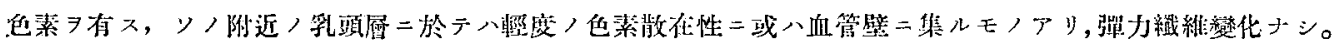

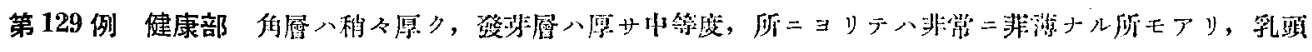

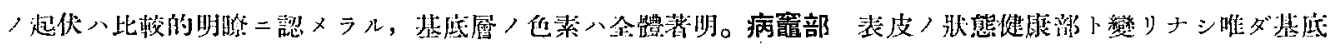

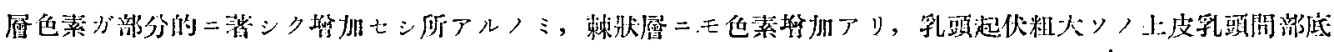

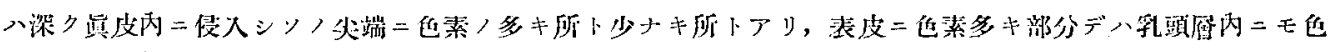

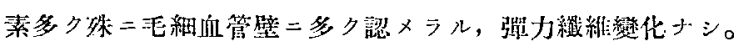

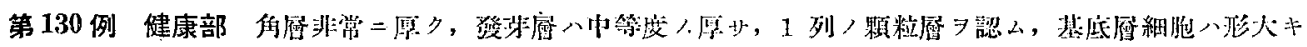

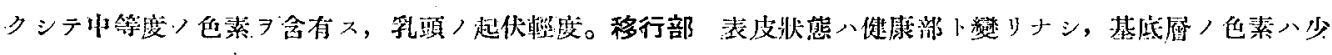

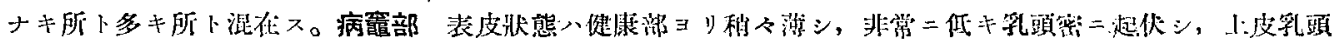

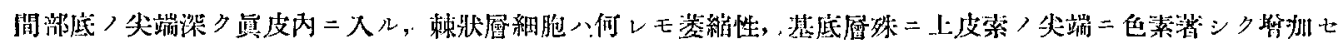

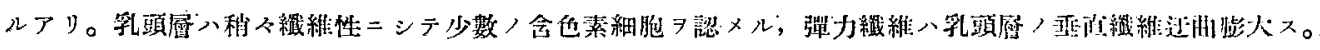




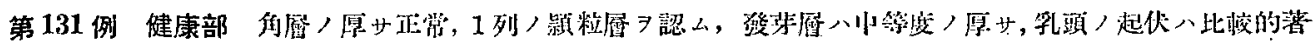

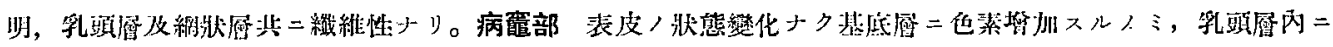

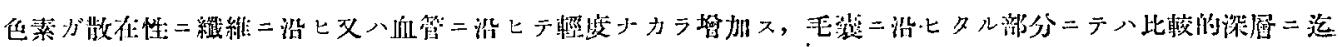

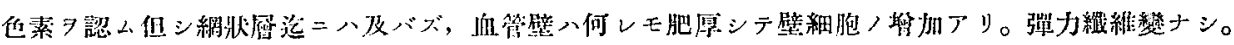

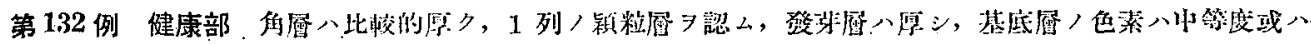

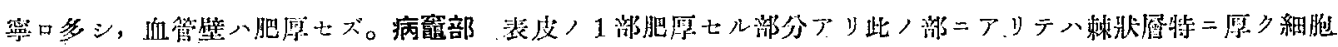

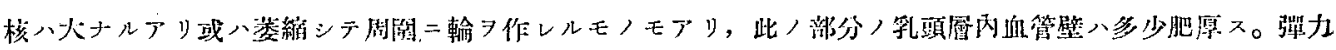
䝔維箵化ナシ。

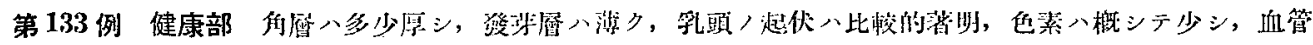

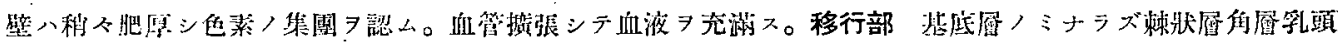

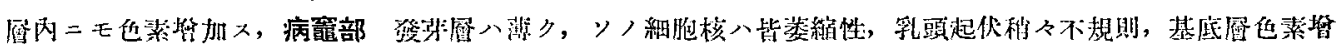

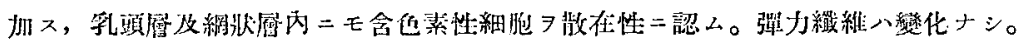

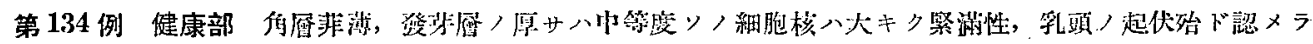

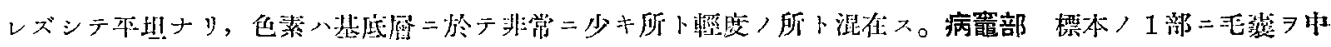

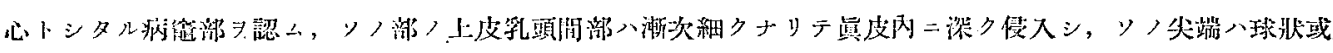

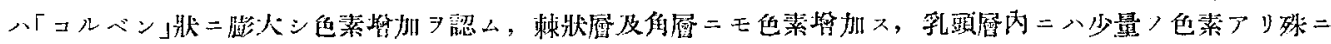

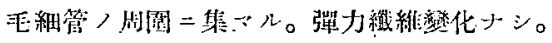

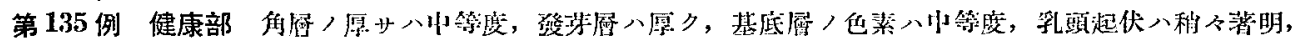

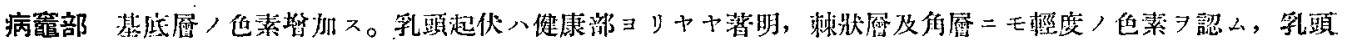

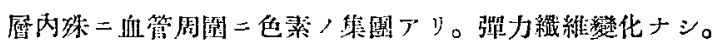

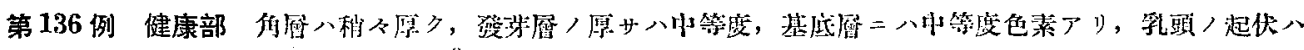

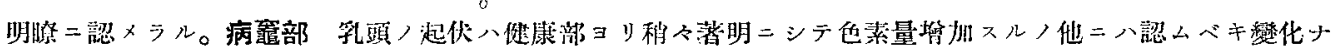

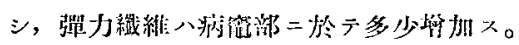

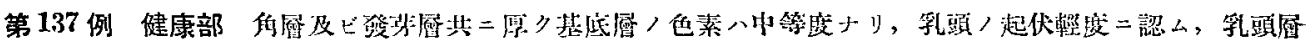

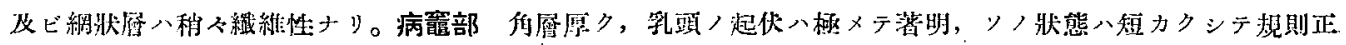

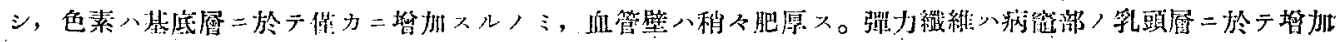
ス。

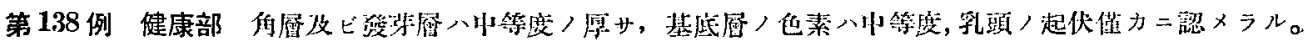

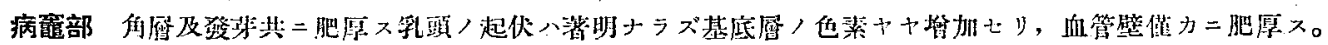

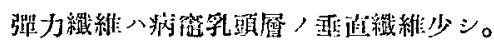

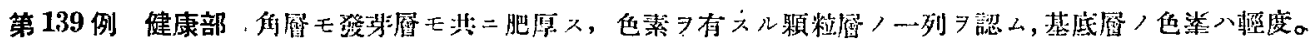

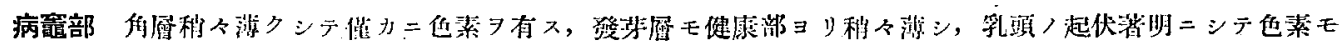

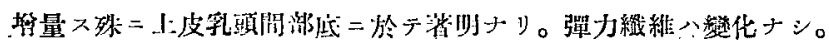

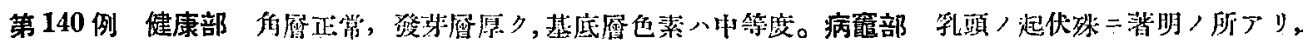

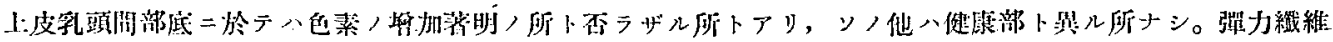


攀化ナシ。

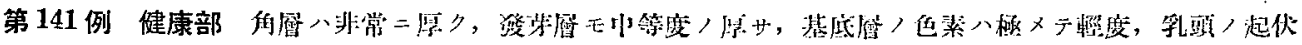

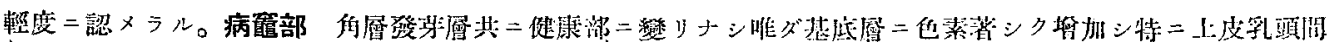

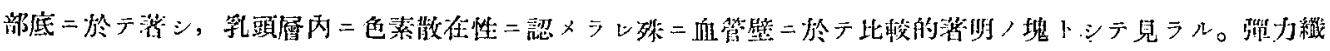
維䋖化ナシ。

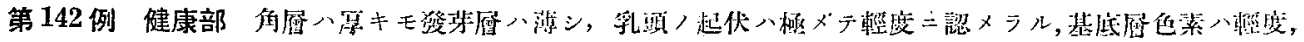

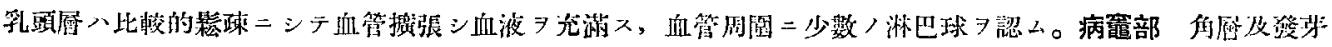

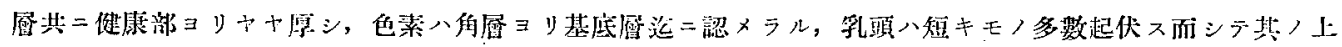

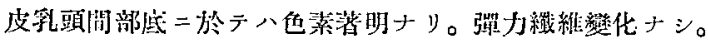

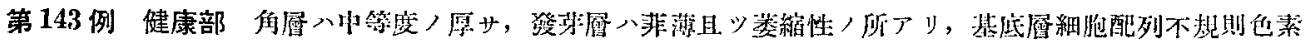

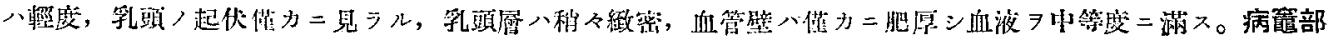

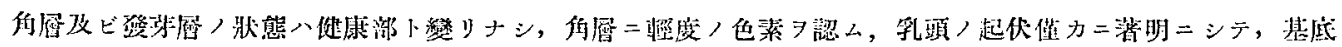

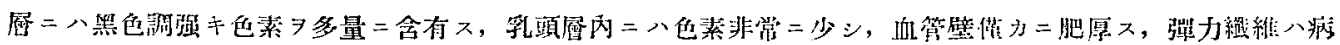

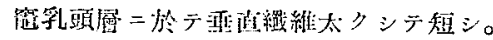

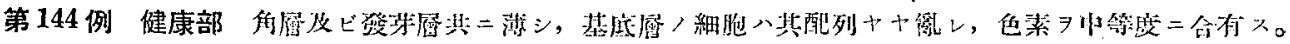

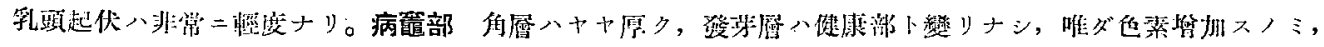

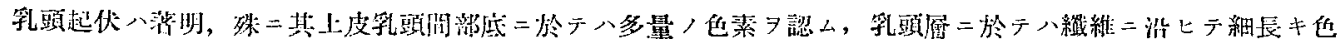

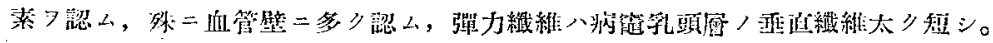

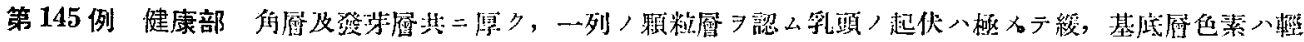

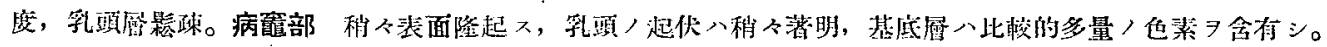

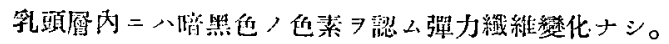

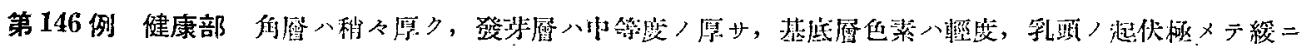

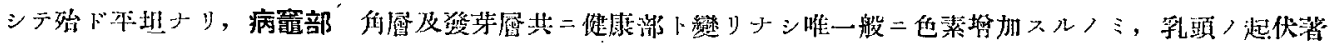

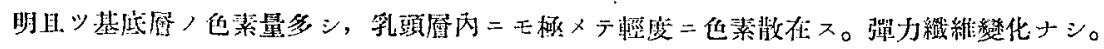

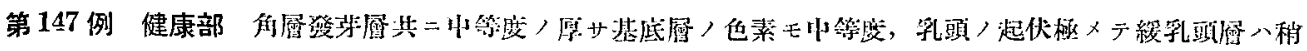

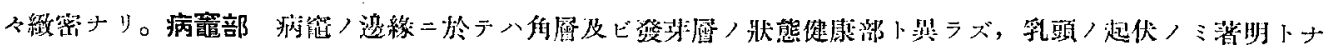

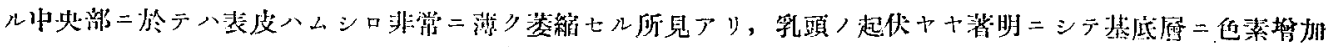

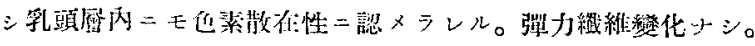

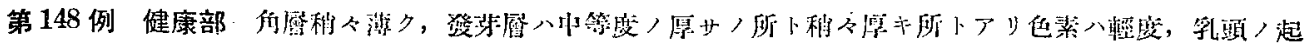

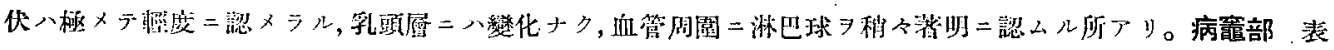

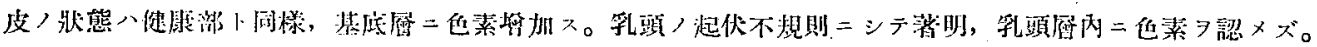

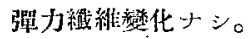

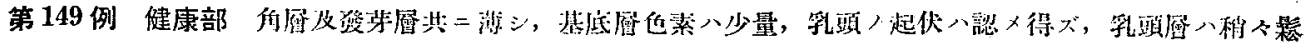

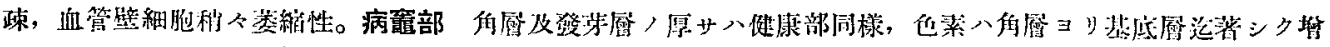

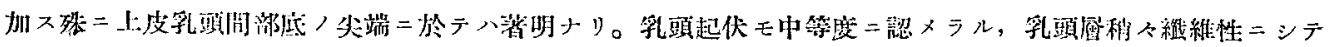




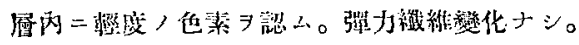

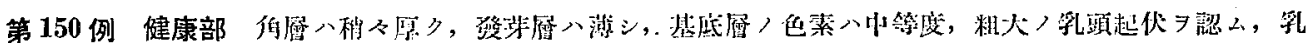

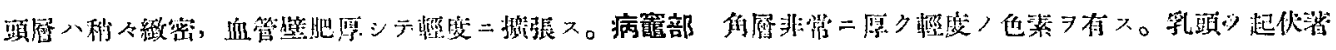

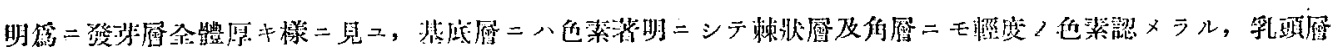

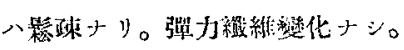

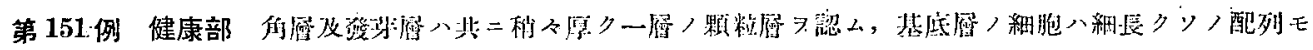

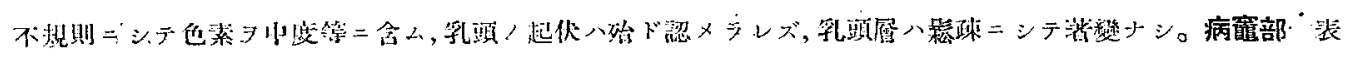

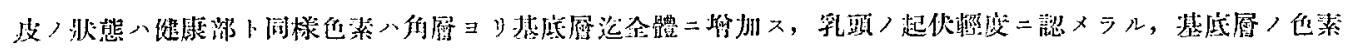

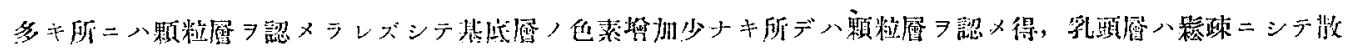

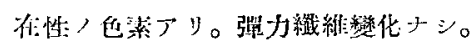

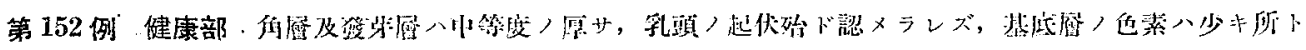

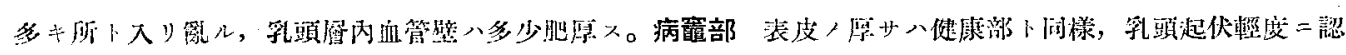

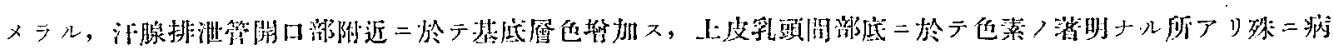

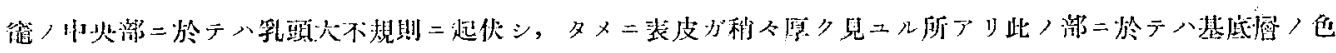

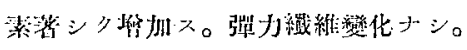

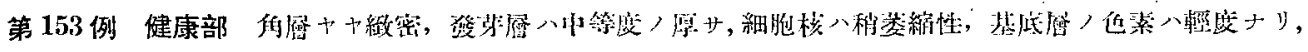

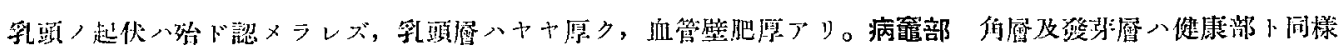

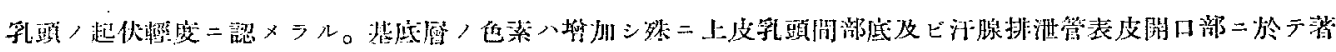

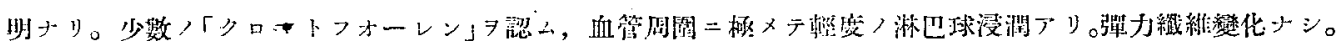

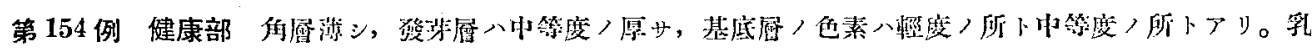

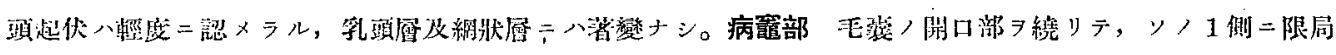

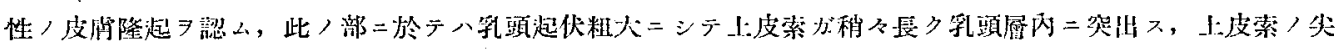

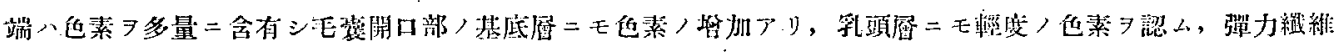
繁化ナシ。

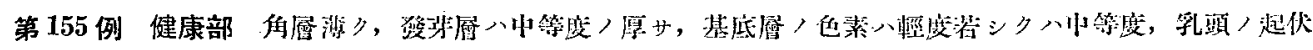

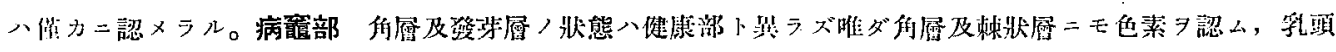

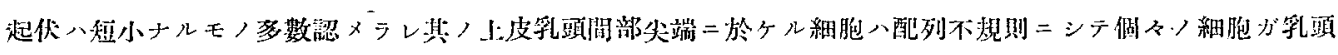

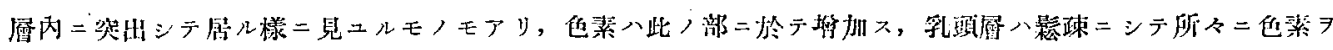

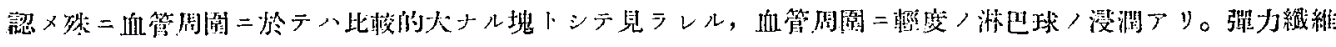
變化ナシ。

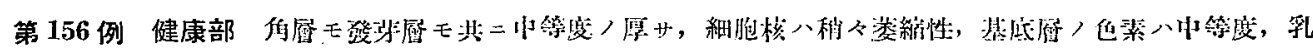

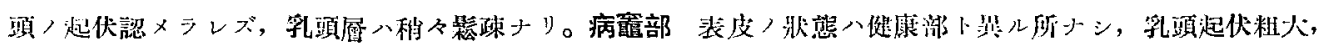

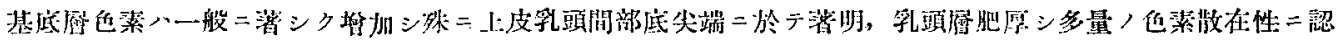

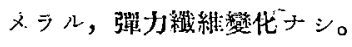

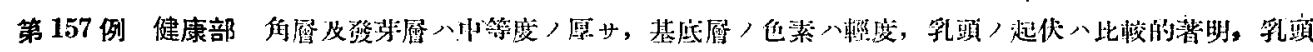
$-1000-$ 


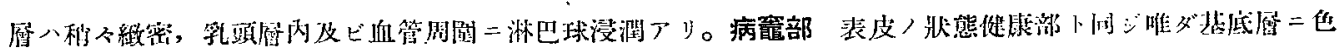

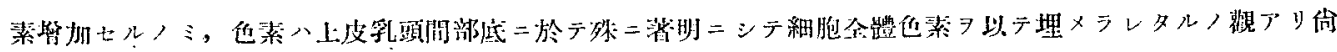

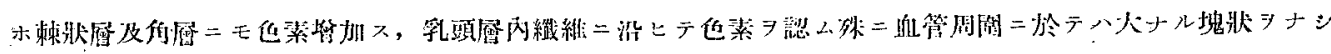

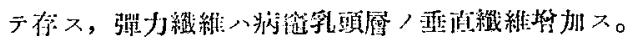

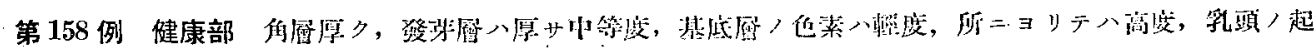

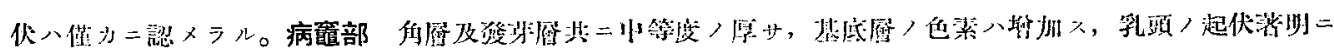

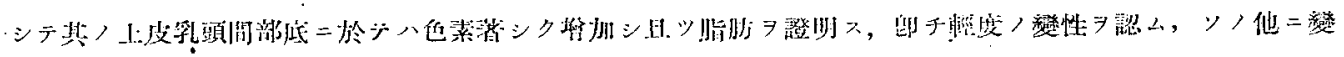

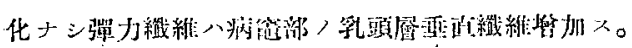

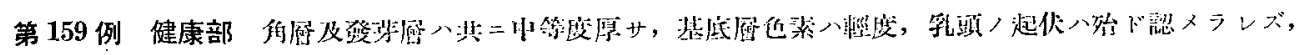

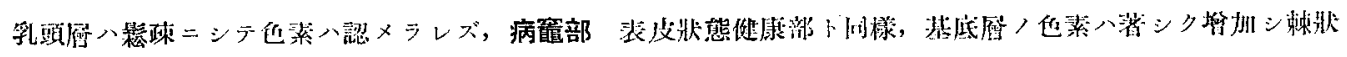

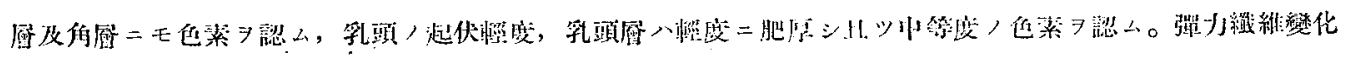
ナシ。

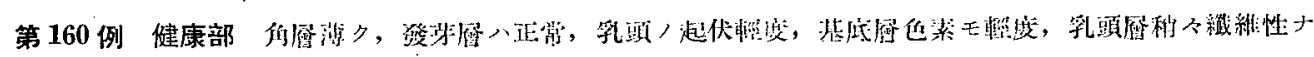

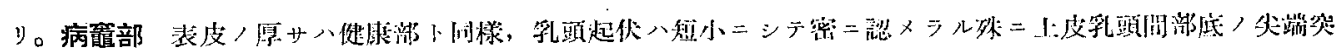

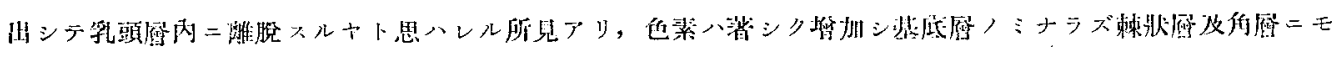

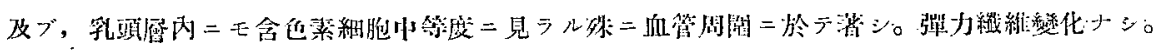

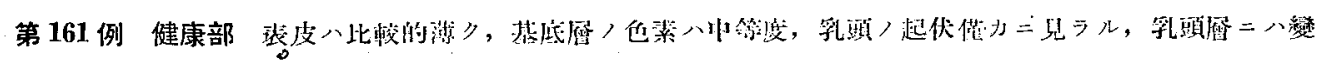

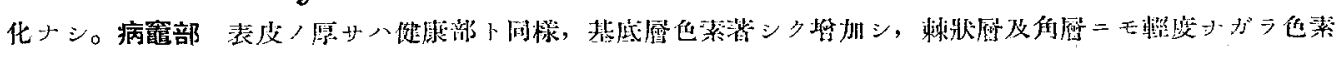

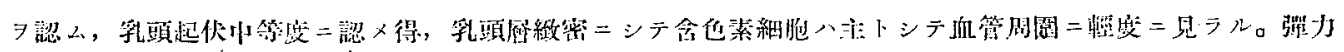
瀻維灣化ナシ。

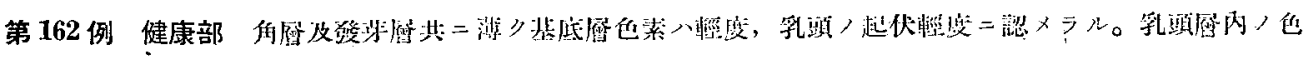

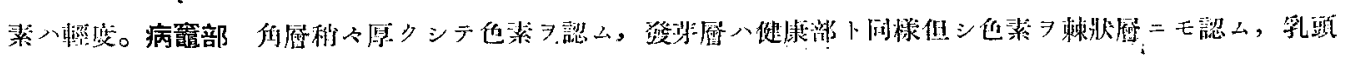

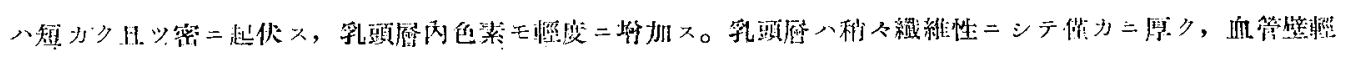

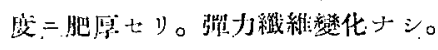

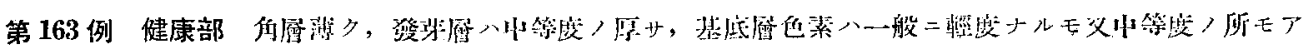

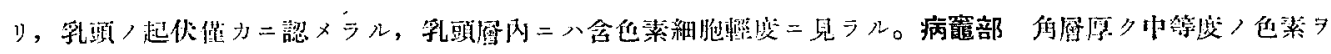

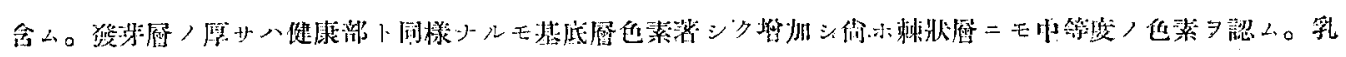

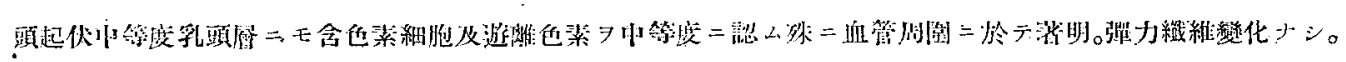

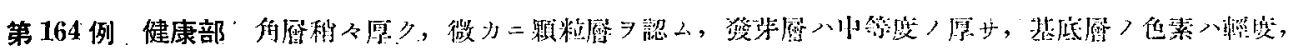

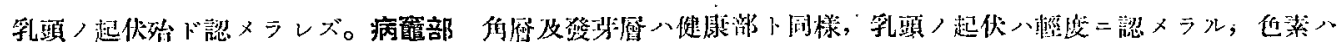

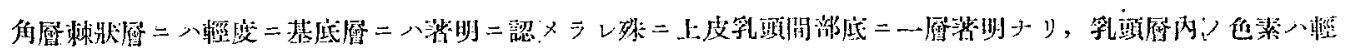

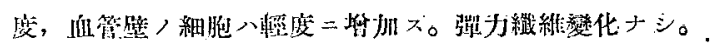

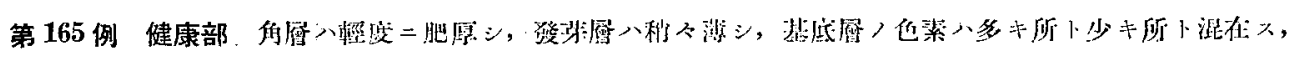

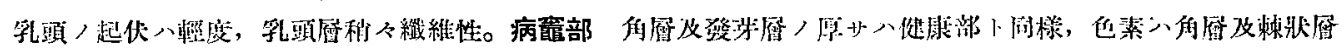

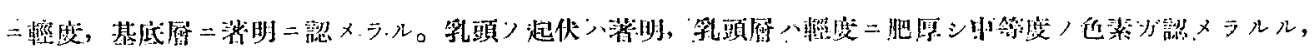




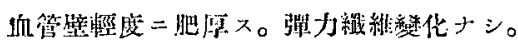

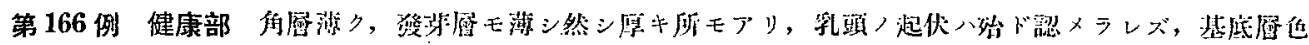

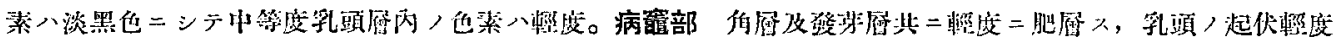

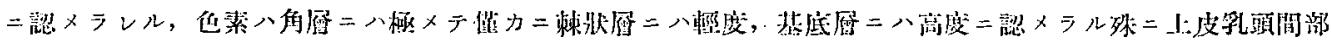

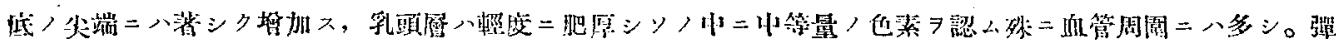
力維維變化ナシ。

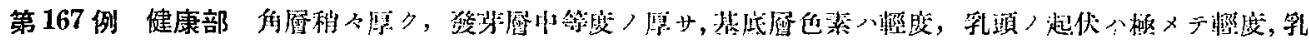

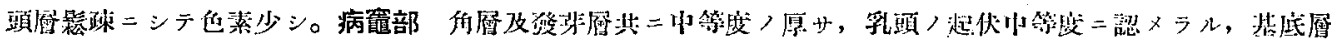

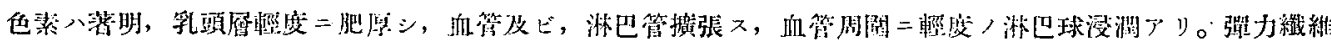
整化ナシ。

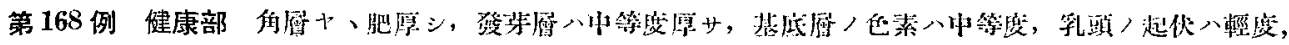

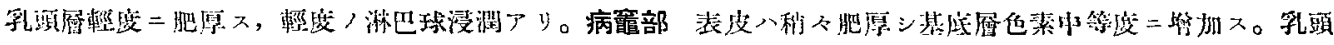

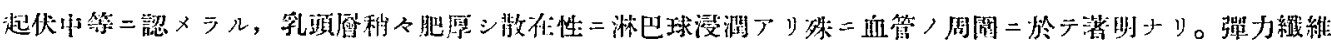
綮化ナシ。

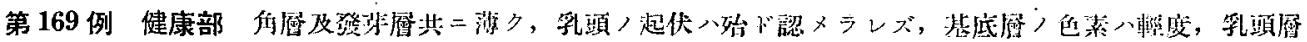

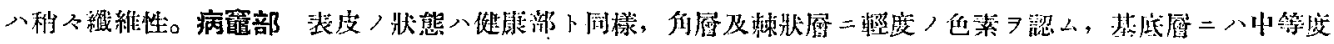

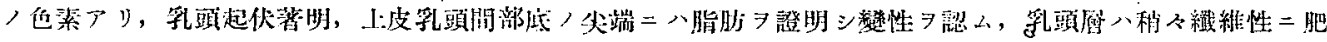

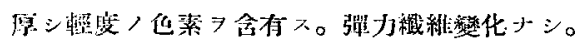

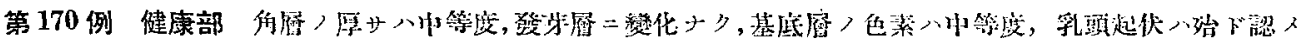

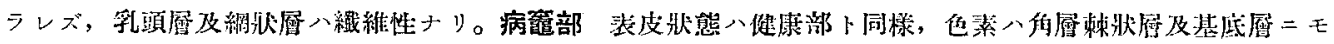

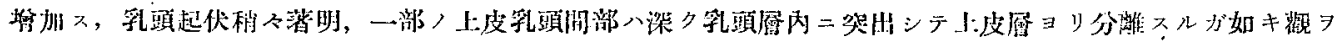

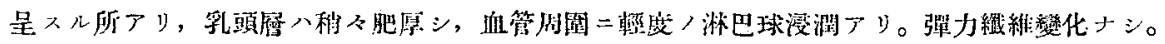

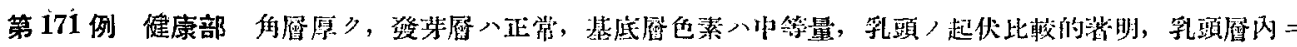

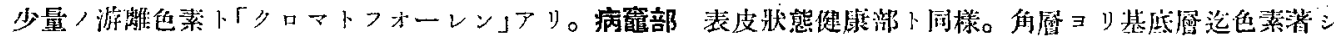

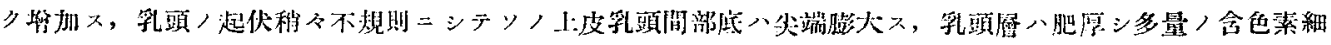

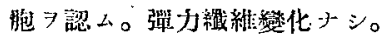

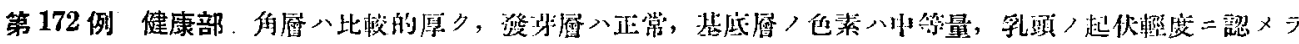

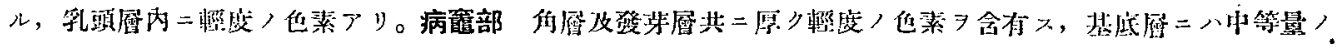

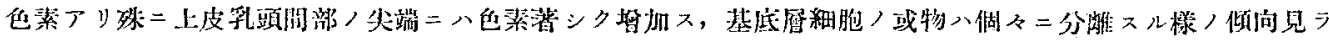

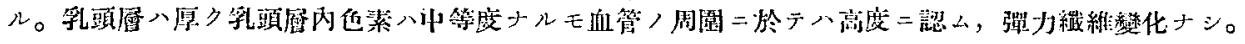

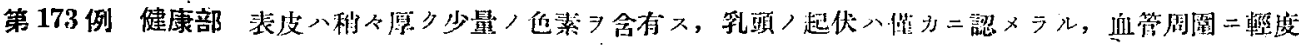

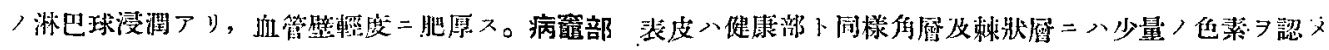

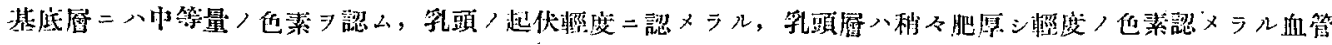
壁一肥厚ス。彈力瀻維變化ナシ。

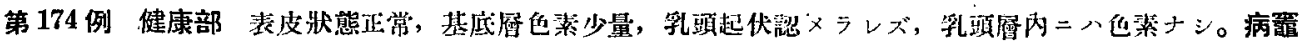




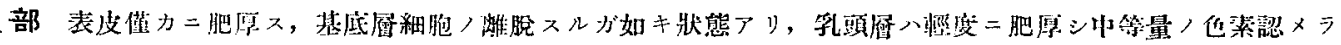

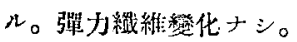

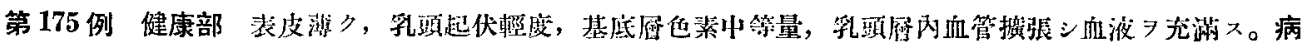

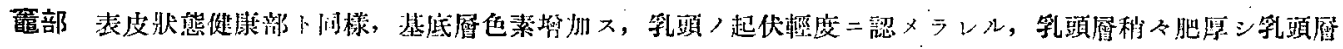

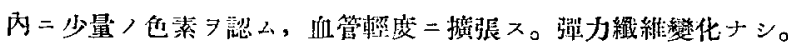

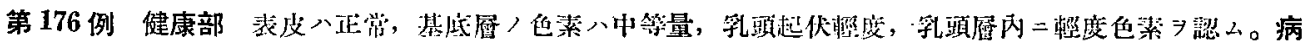

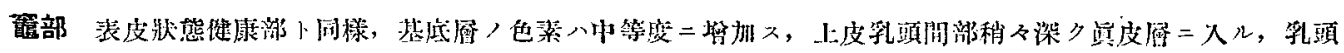

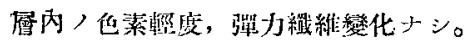

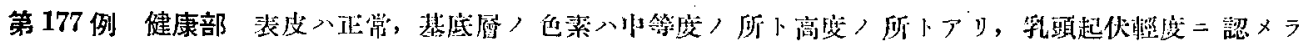

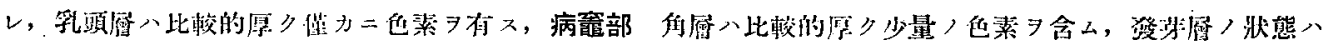

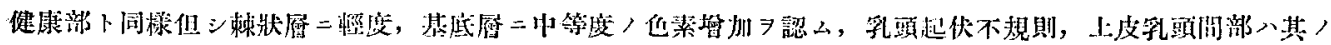

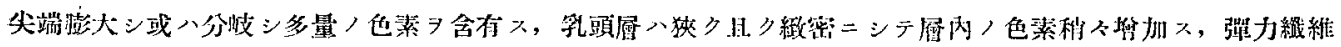
遂化ナシ。

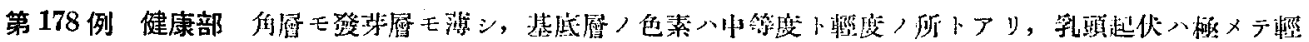

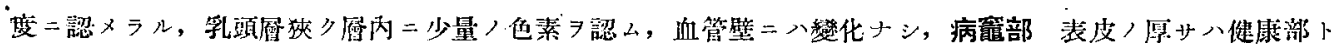

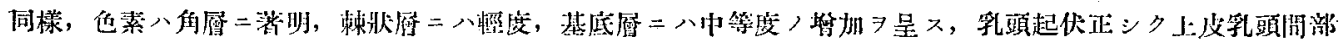

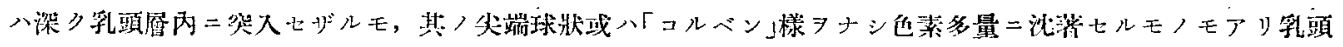

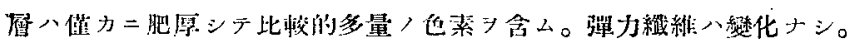

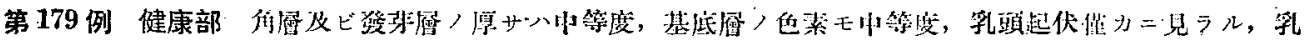

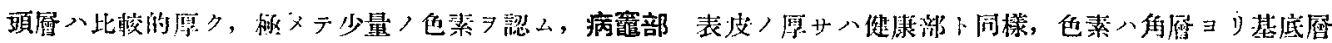

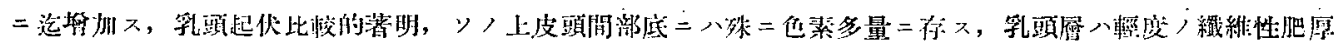

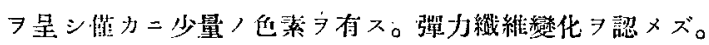

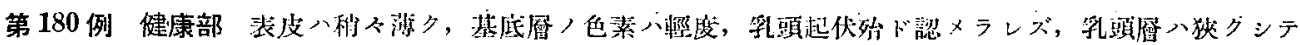

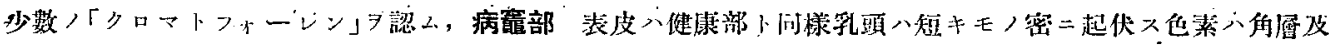

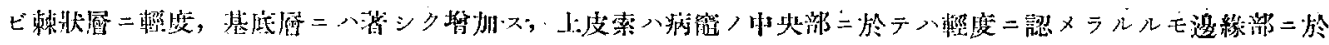

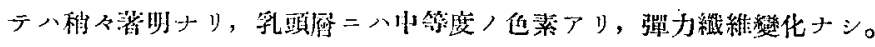

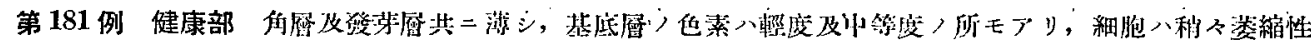

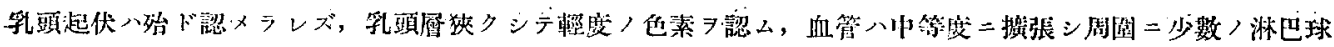

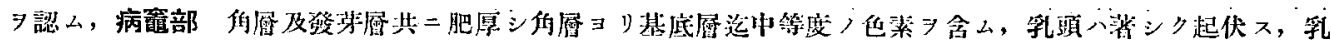

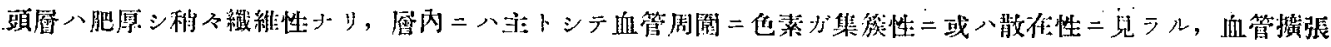

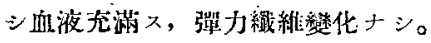

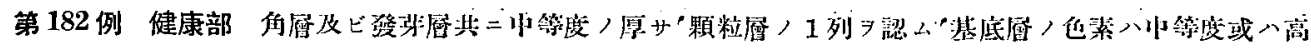

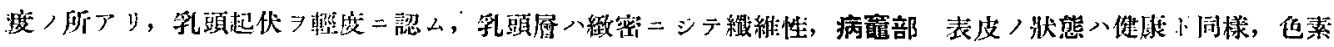

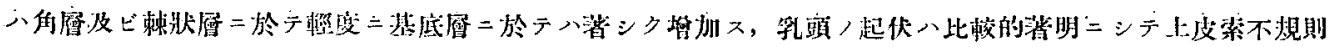

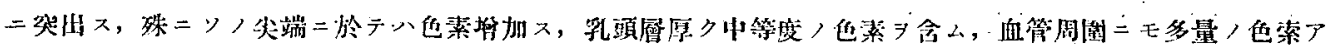




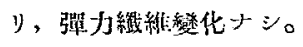

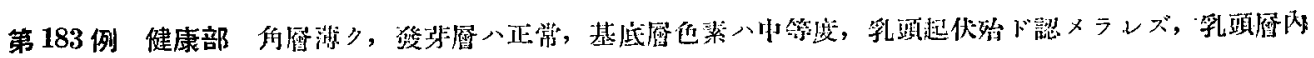

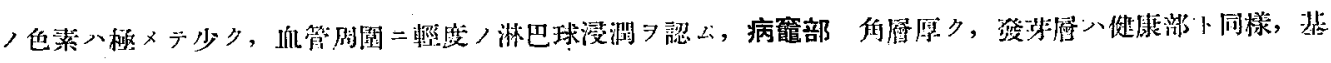

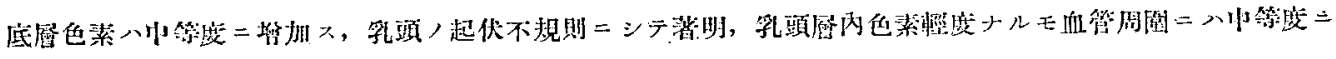

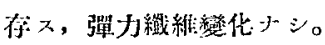

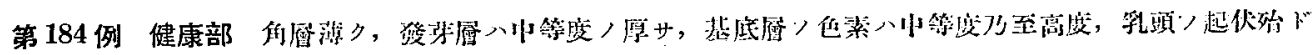

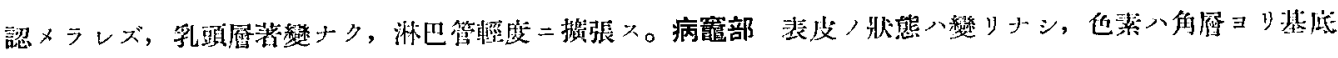

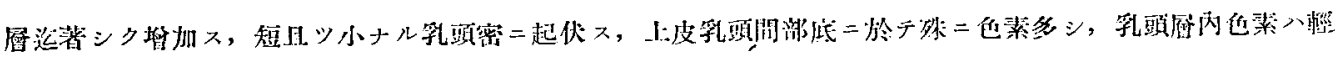

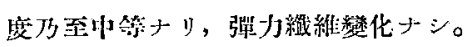

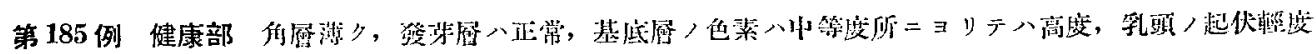

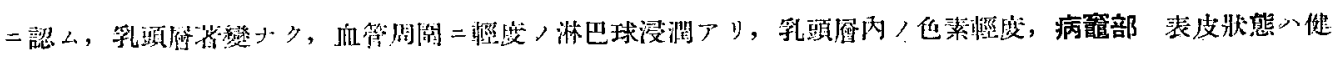

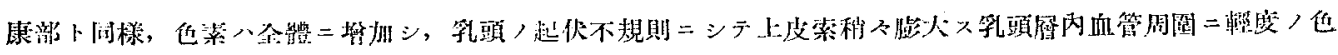

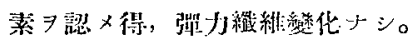

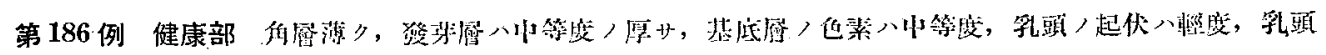

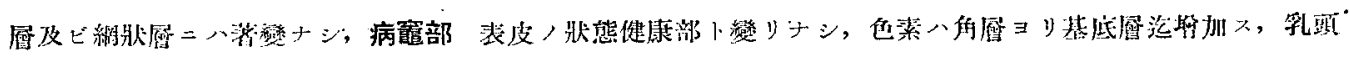

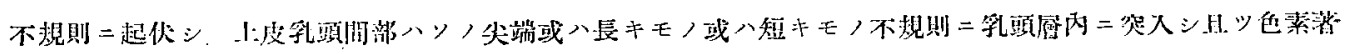

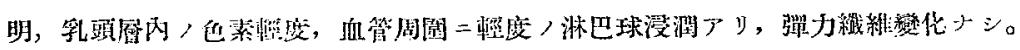

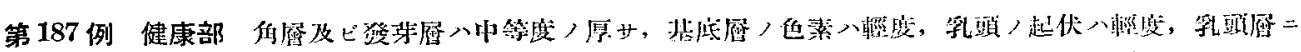

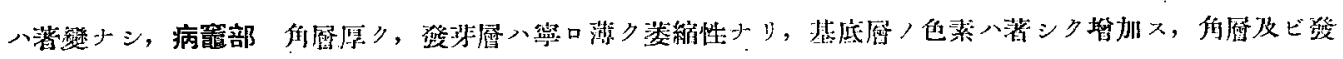

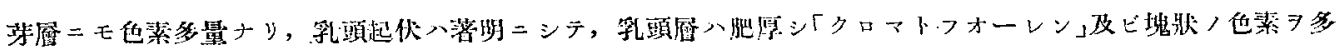

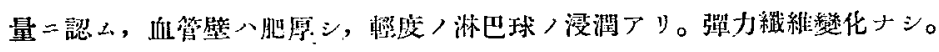

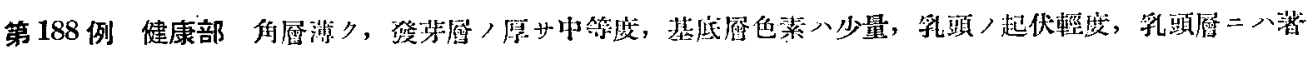

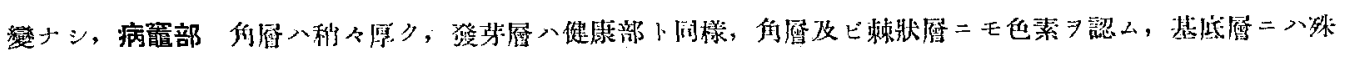

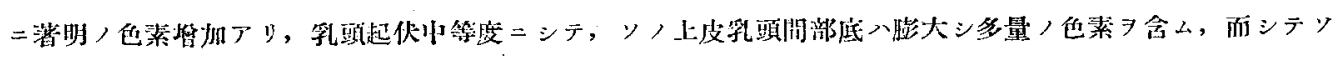
八尖端二於テハ上支衙

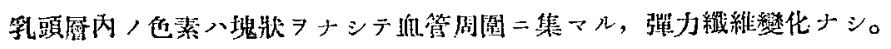

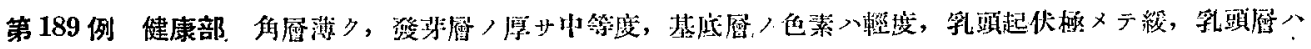

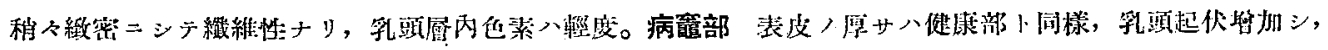

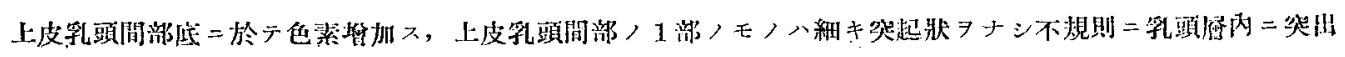

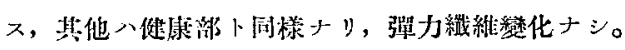

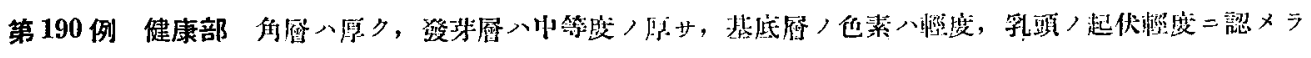

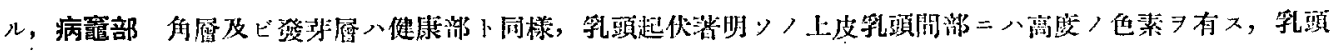

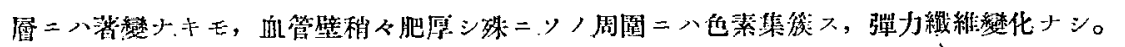

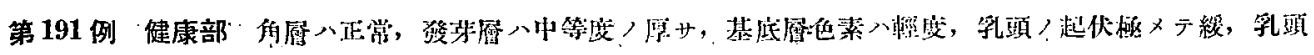

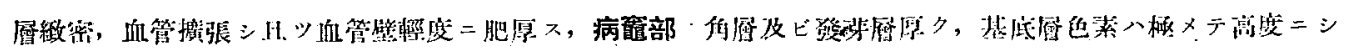




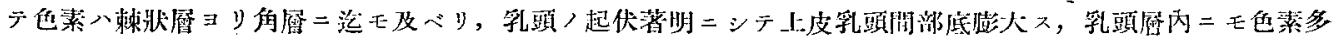
量ナリ，彈力䄉維變化ナシ。

\section{5. 第五 型}

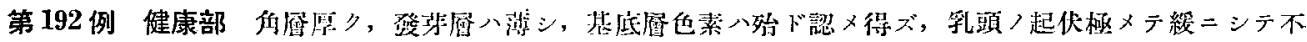

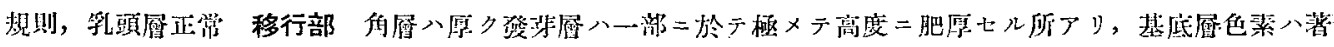

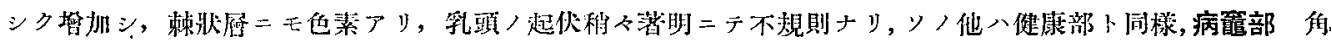

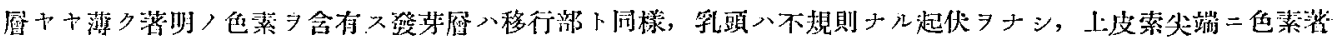

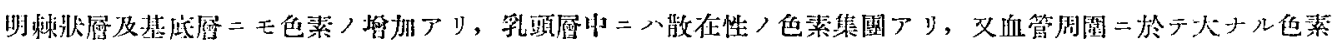

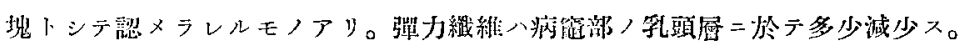

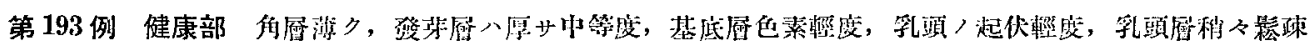

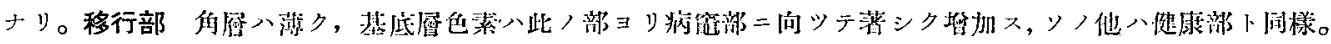

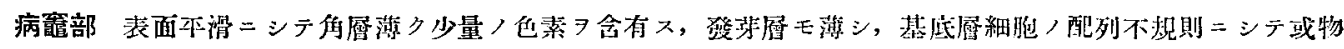

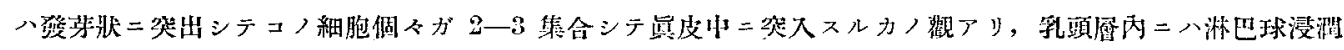

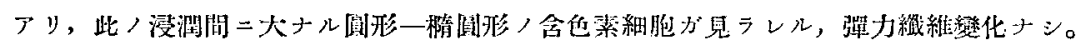

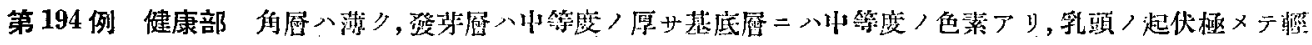

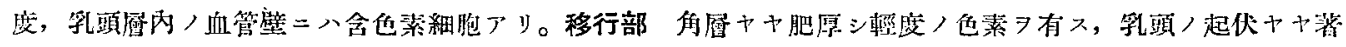

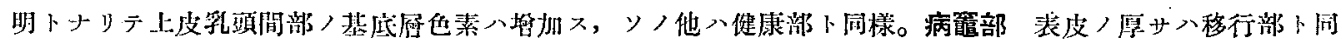

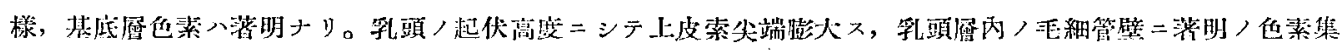

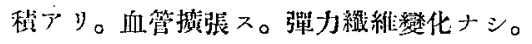

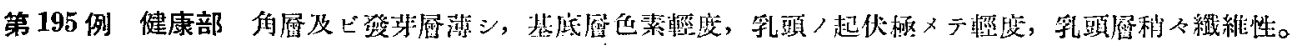

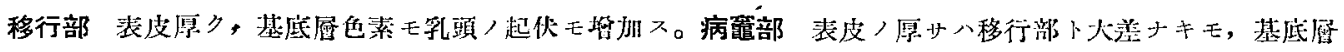

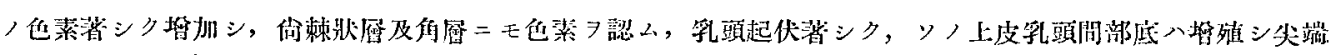

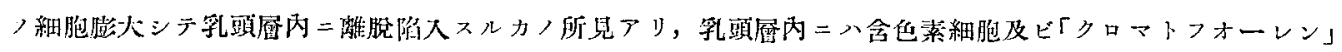

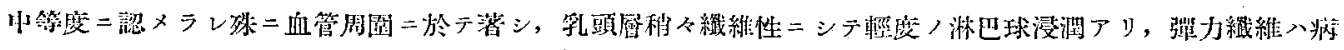
窝部，乳頍屈二於テャャ減少メ。

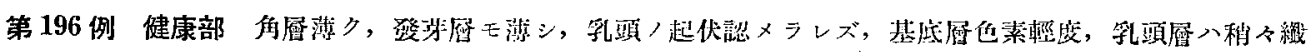

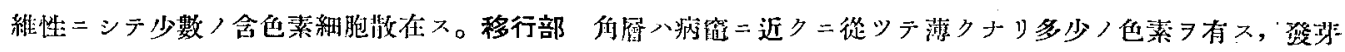

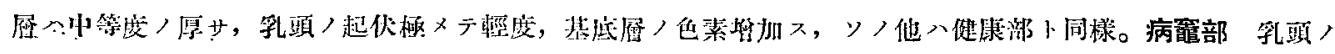

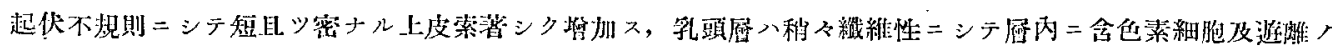

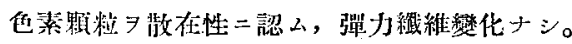

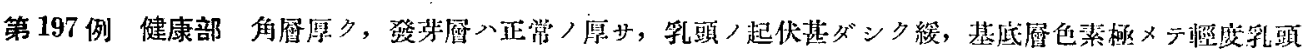

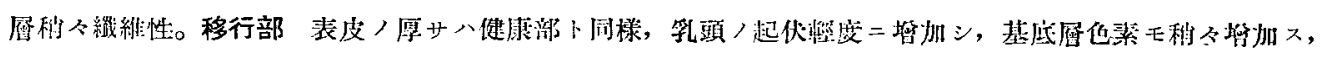

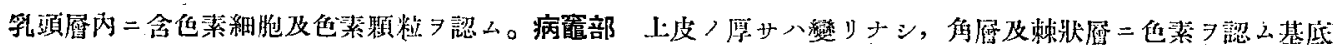

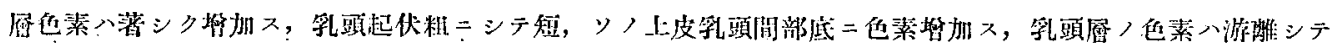

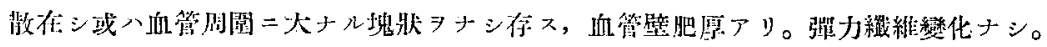




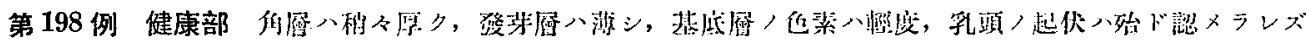

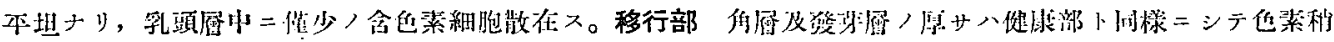

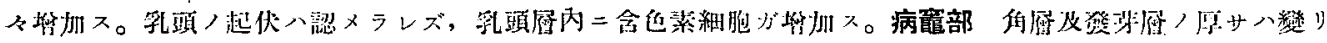

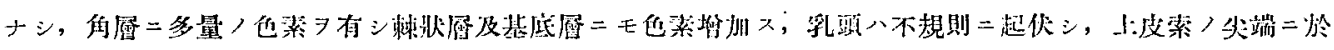

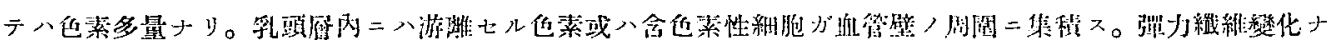
シ。

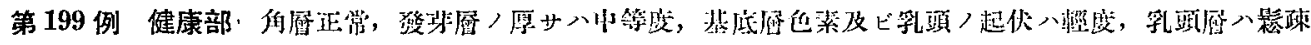

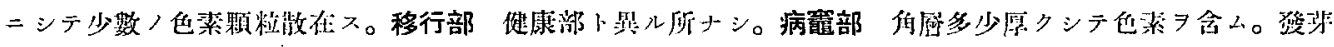

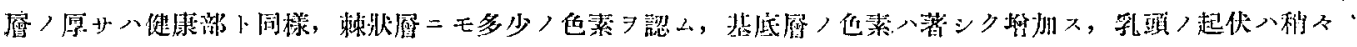

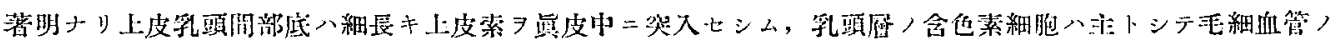

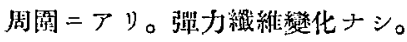

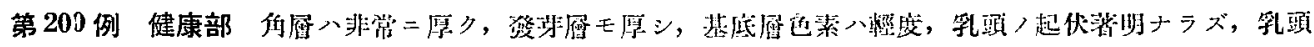

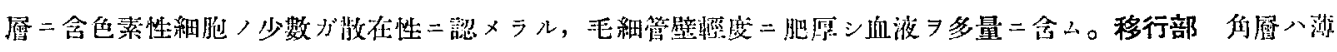

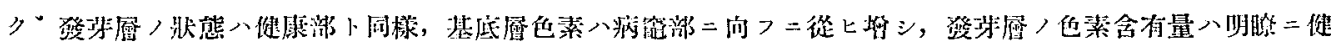

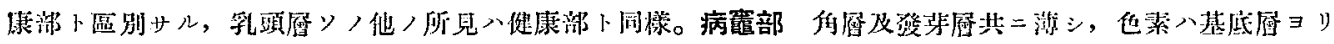

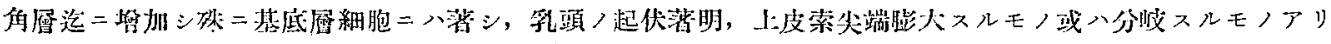

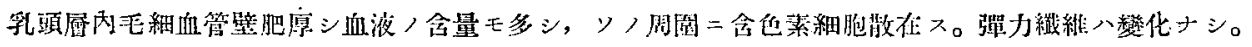

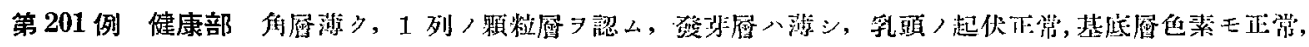

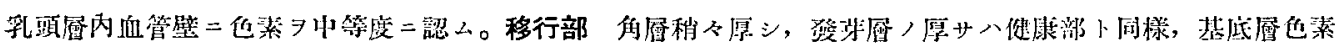

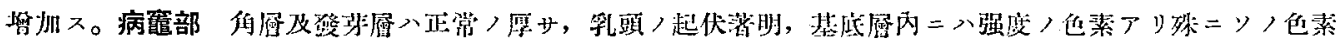

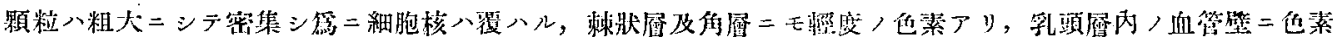

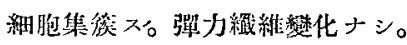

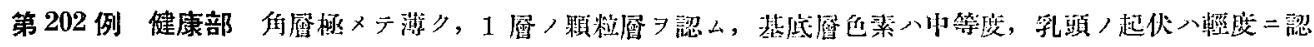

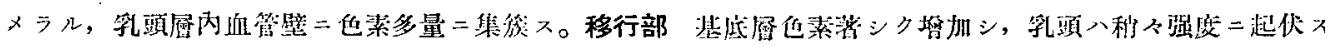

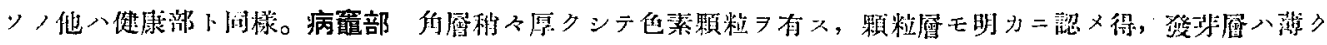

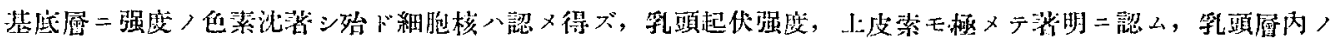

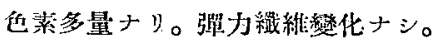

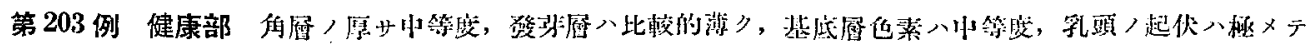

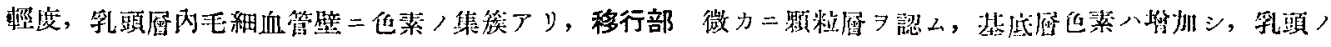

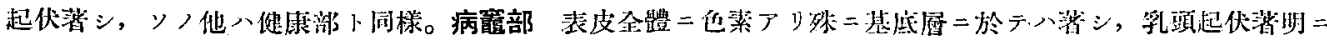

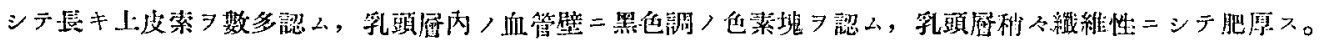
彈力緎維戀化ナシ。

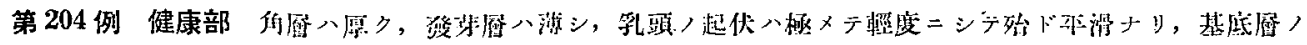

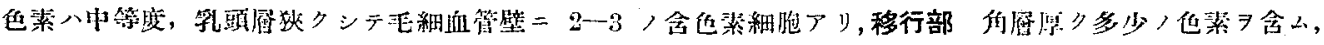

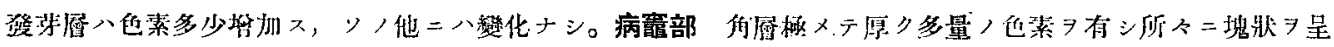




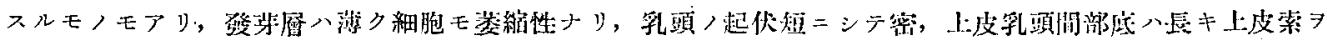

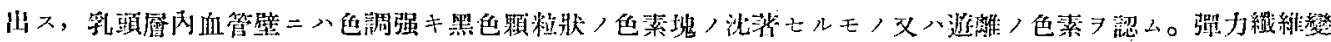
化ナシ。

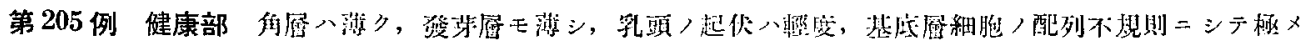

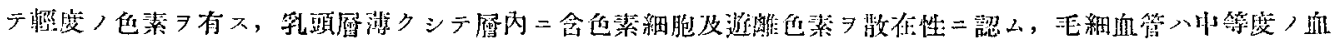

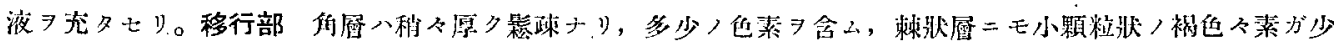

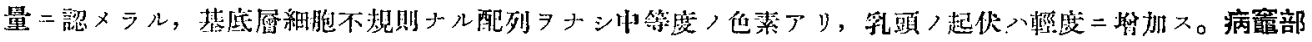

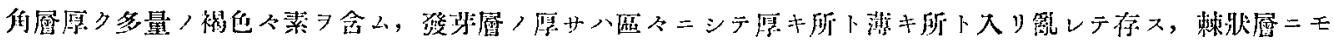

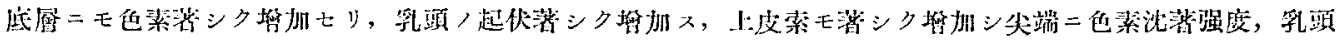

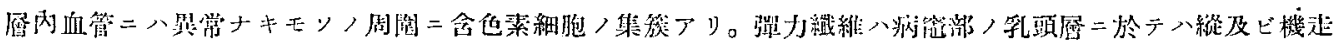
織維興二減少七り。

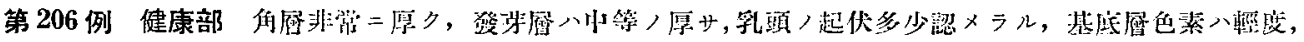

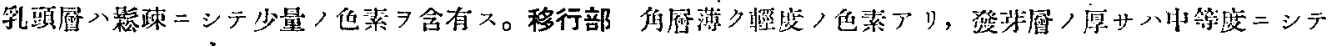

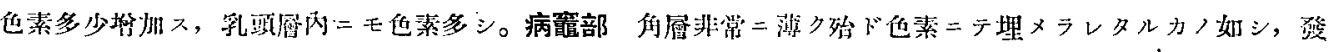

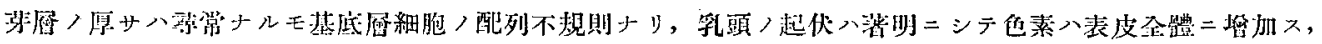

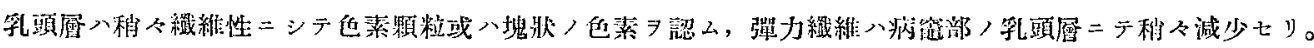

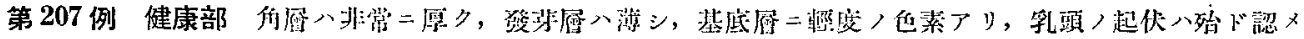

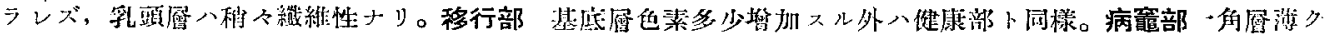

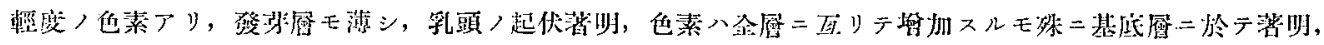

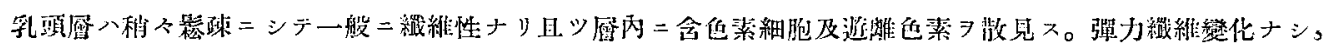

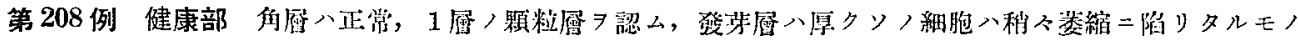

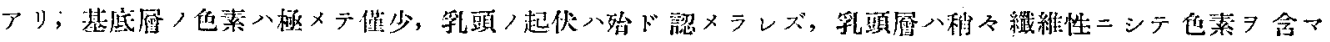

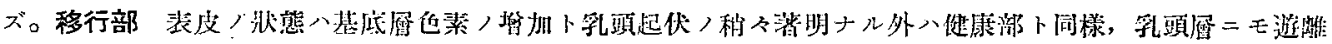

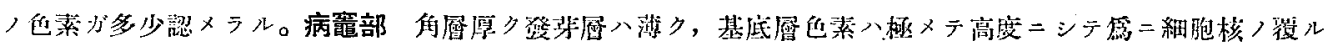

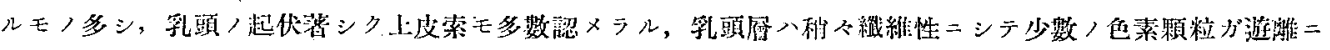

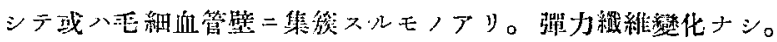

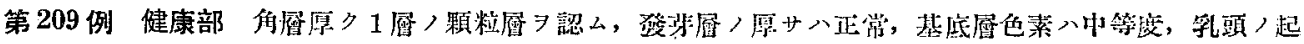

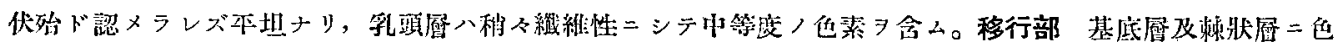

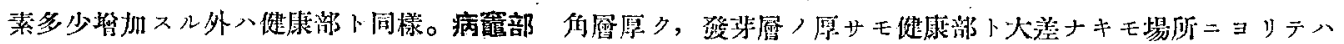

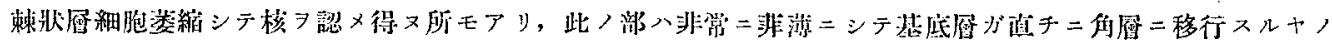

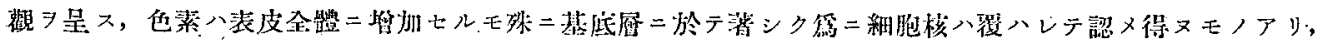

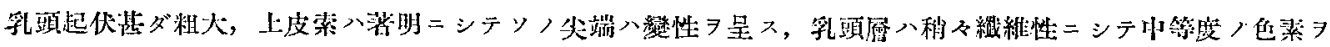

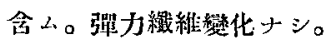

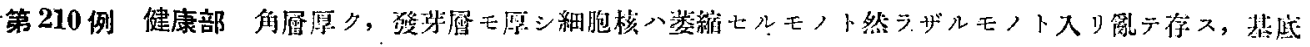

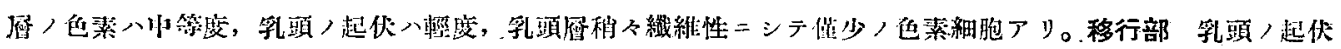




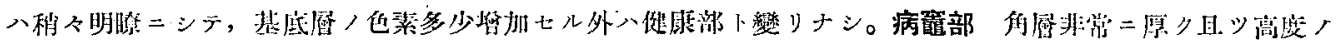

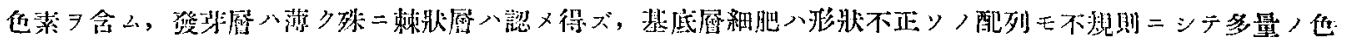

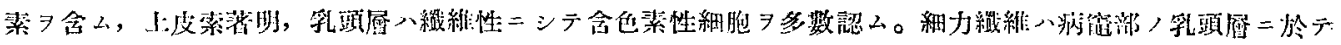
八隇少入。

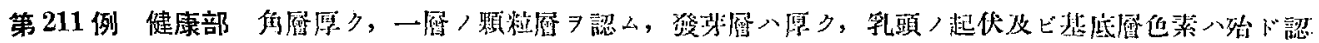

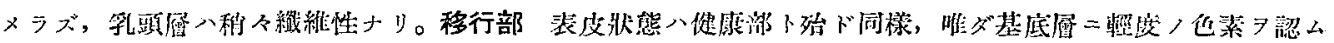

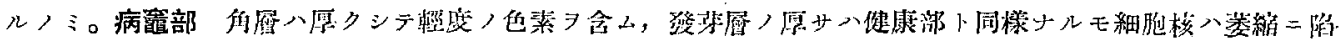

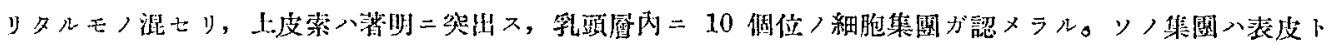

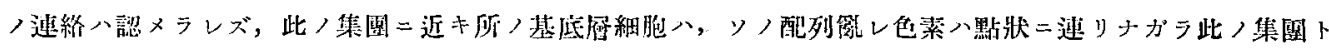

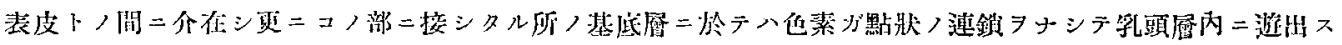

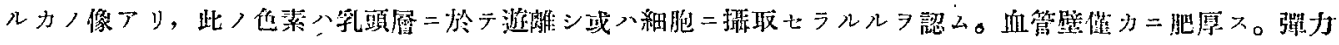
䌖維鐢化ナシ。

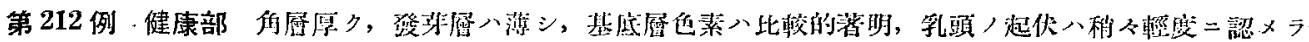

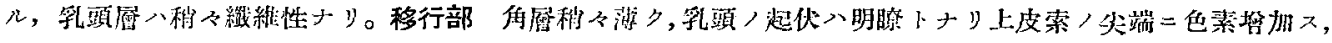

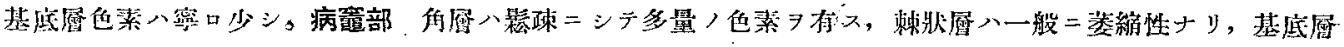

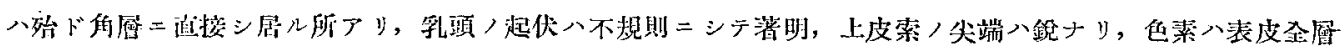

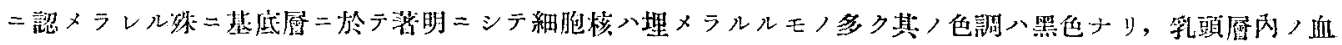

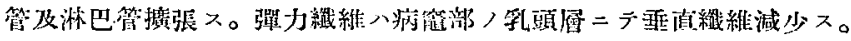

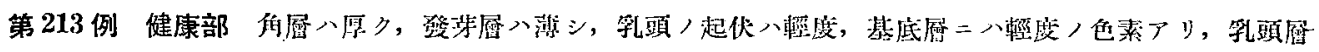

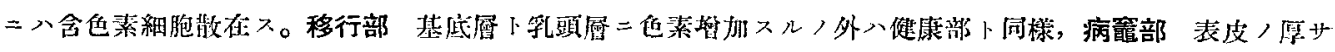

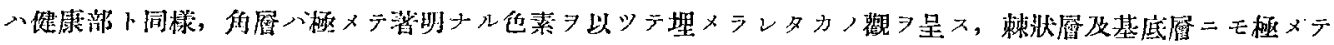

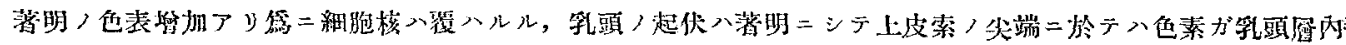

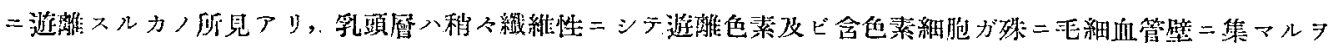

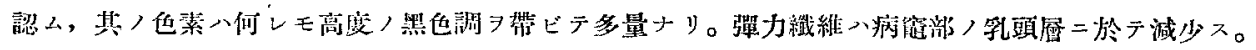

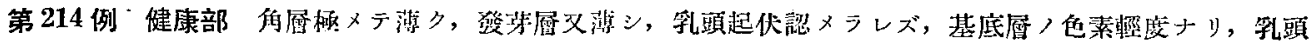

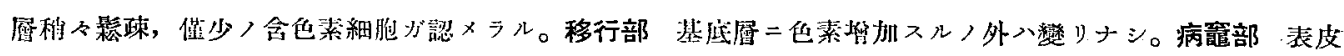

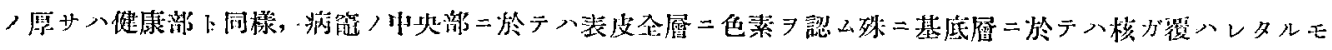

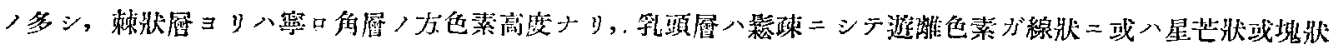

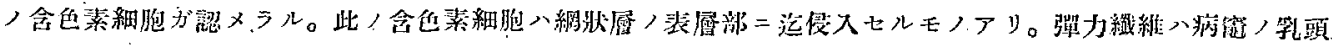

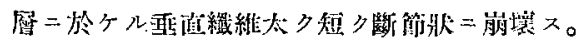

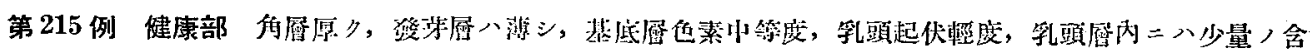

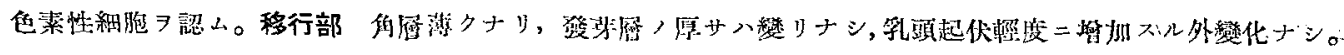

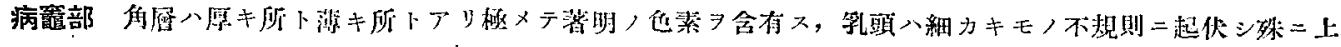

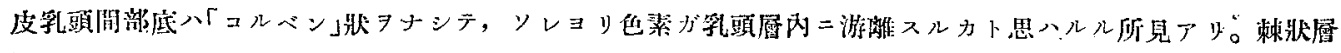

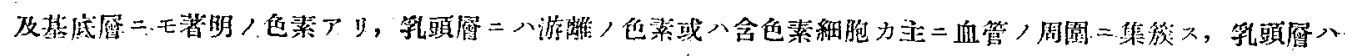


維性ニシテ，血管壁肥厚轅度，彈力織維攀化ナシ。

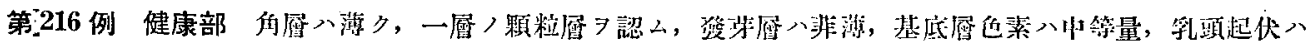

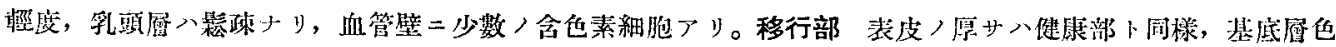

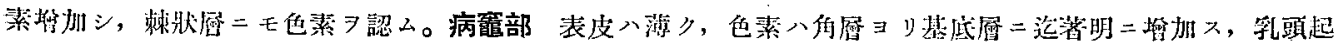

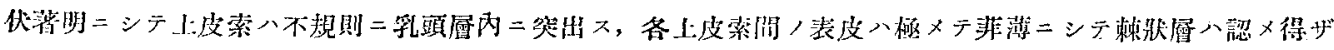

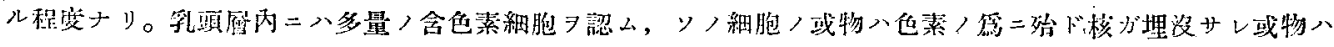

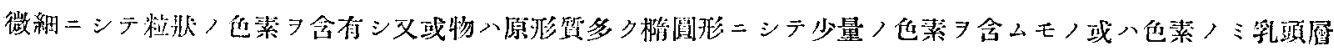

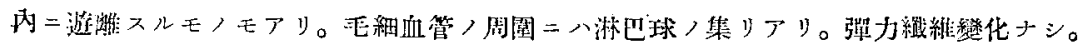

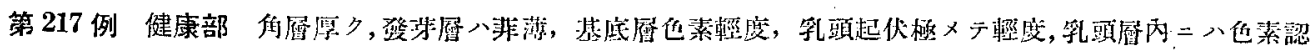

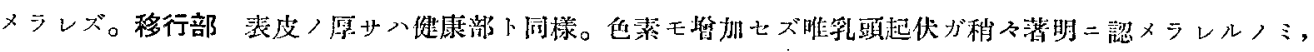

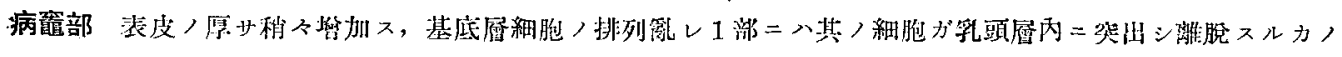

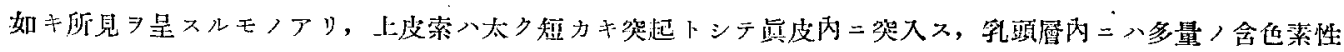

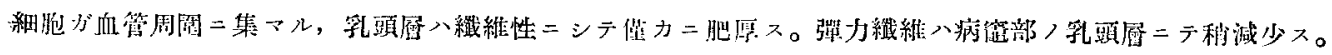

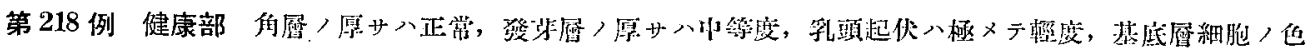

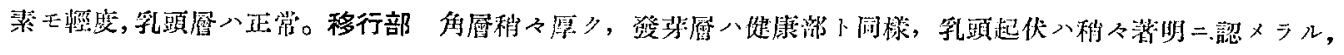

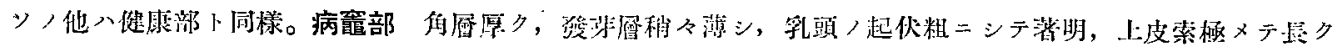

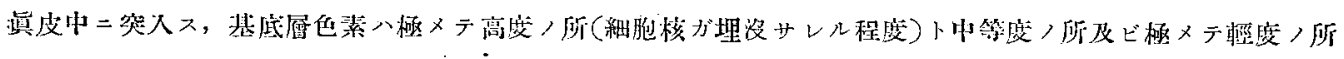

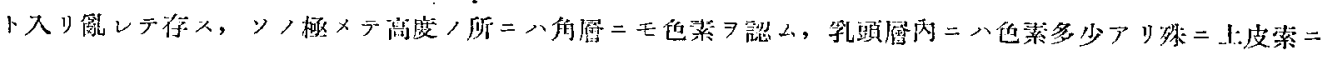

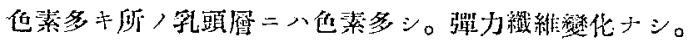

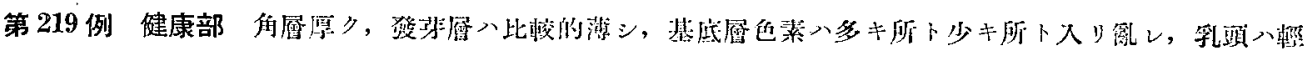

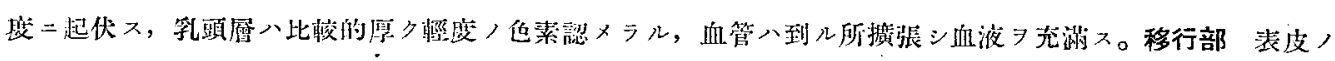

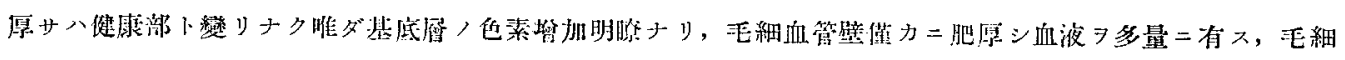

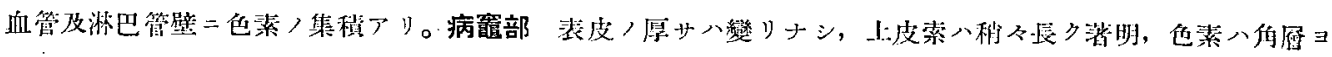

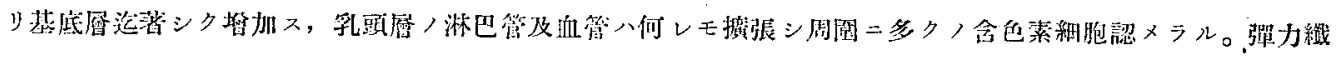

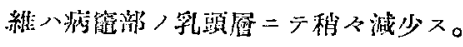

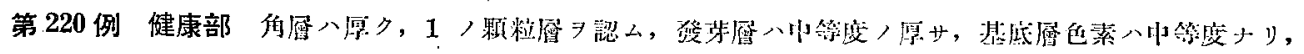

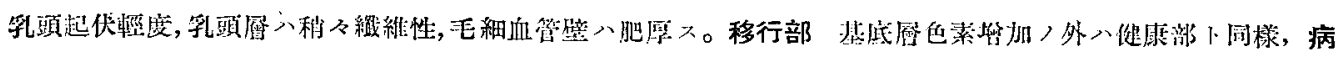

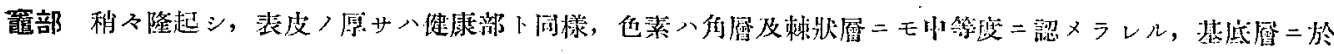

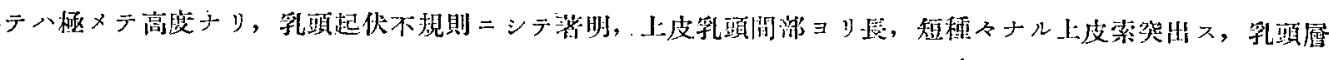

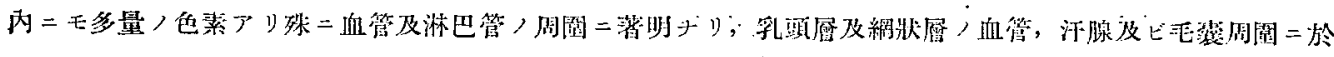

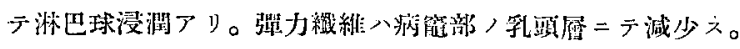

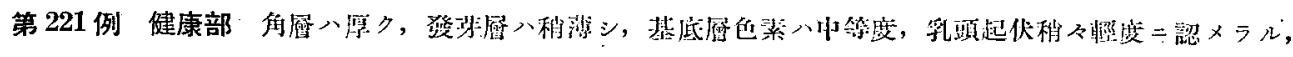

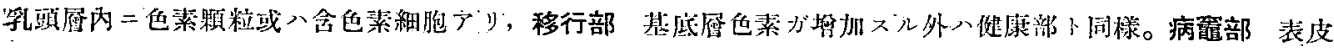

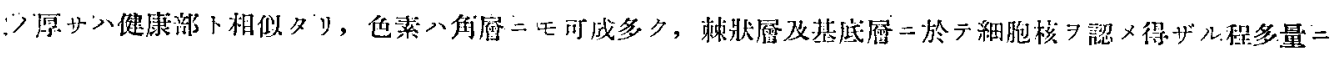

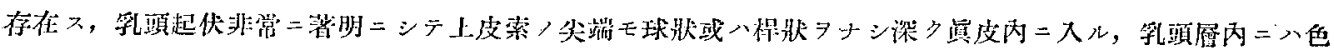




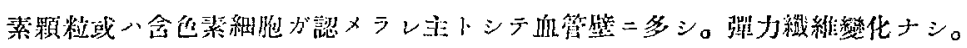

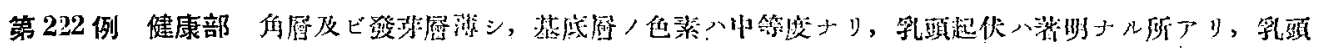

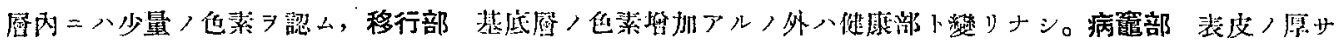

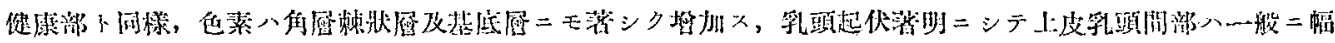

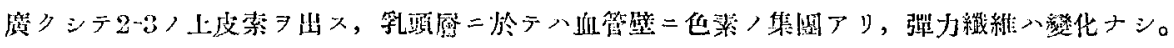

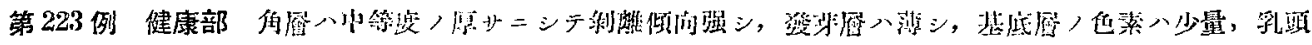

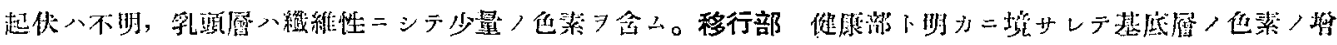

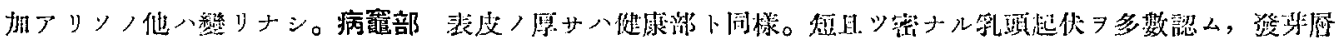

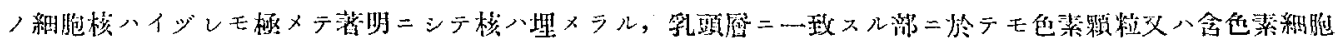

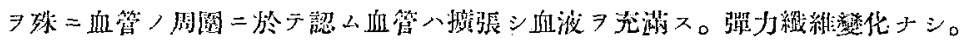

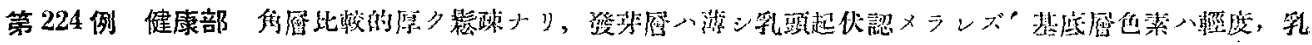

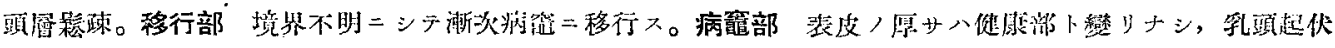

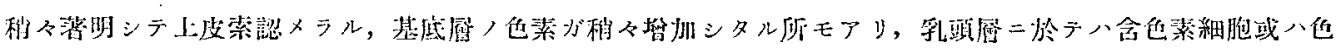

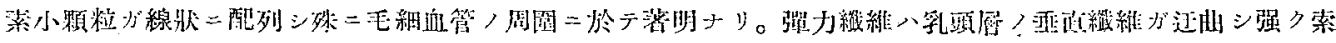
状 $ヨ$ ナ。

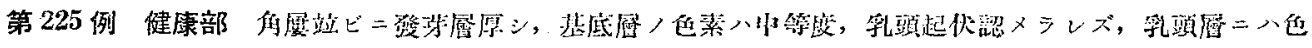

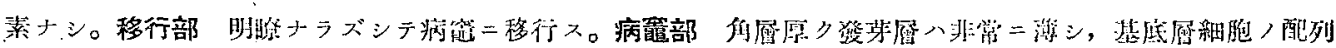

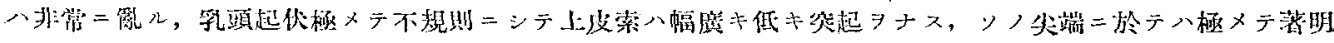

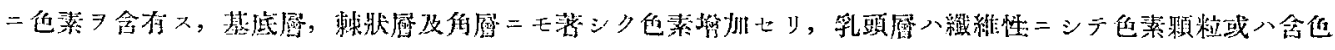

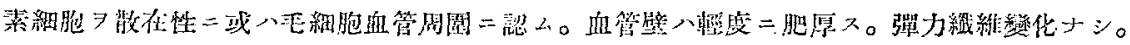

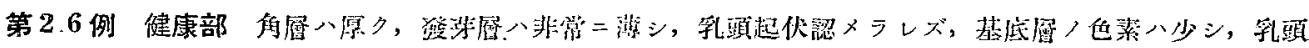

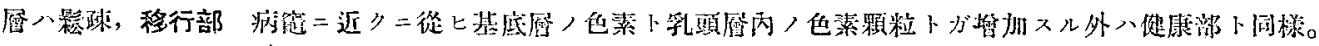

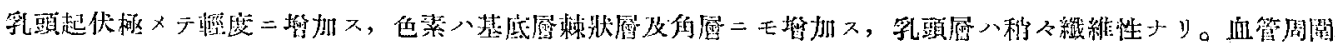

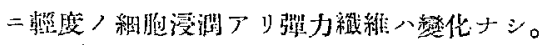

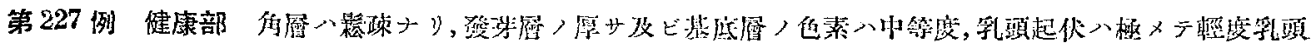

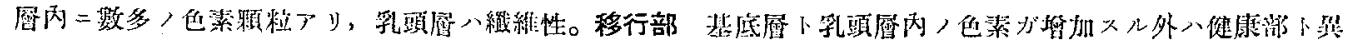

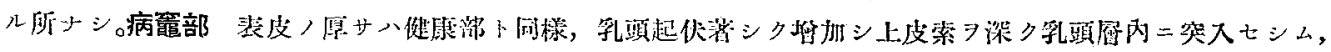

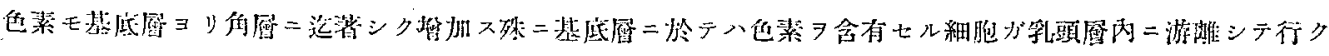

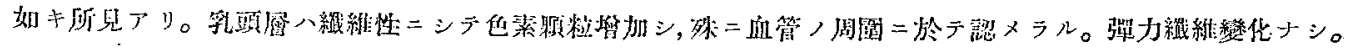

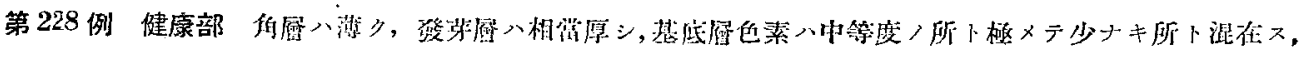

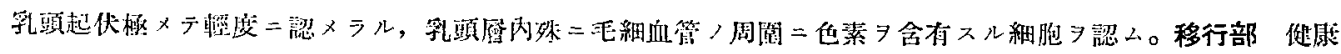

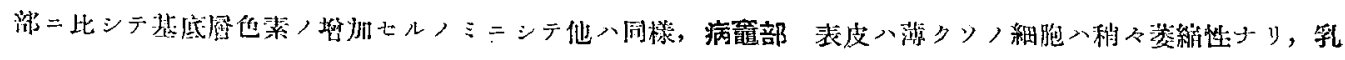

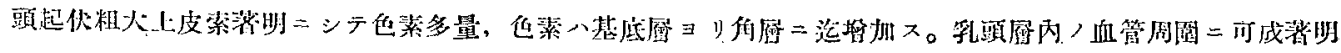

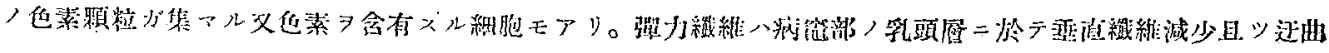
膨大メ。 


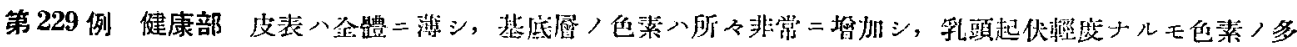

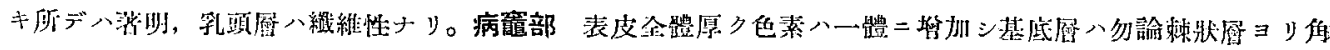

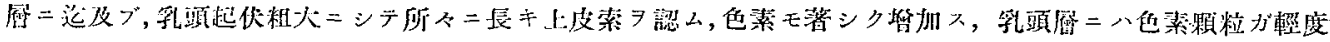

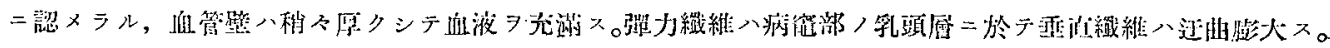

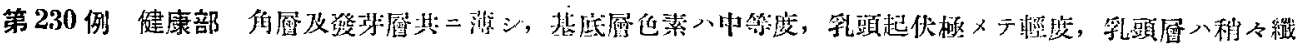

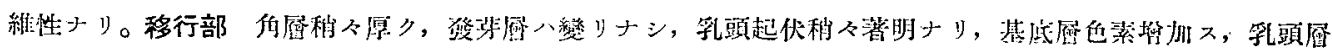

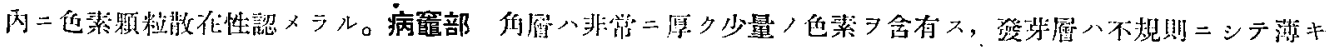

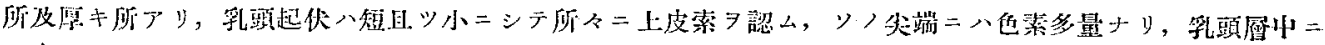

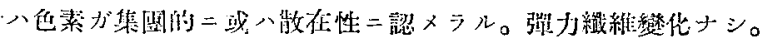

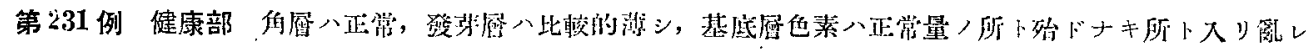

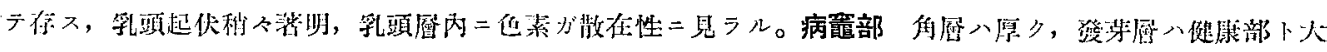

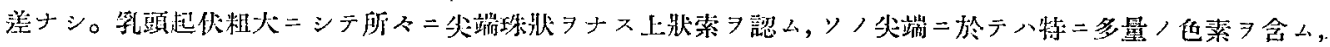

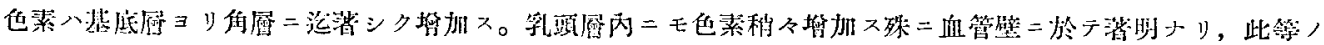

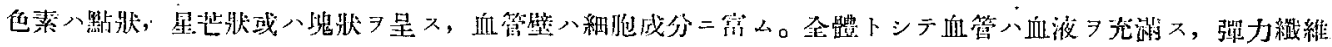
应化ナシ。

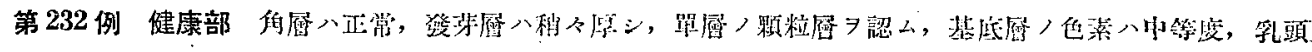

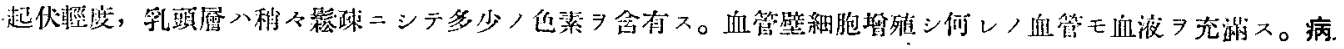

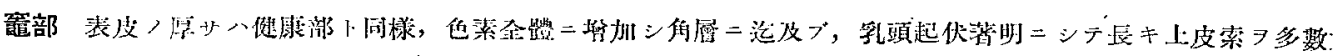

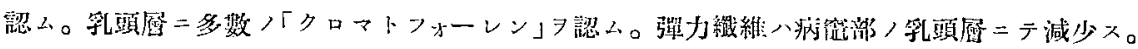

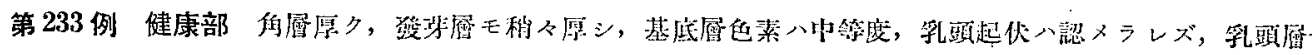

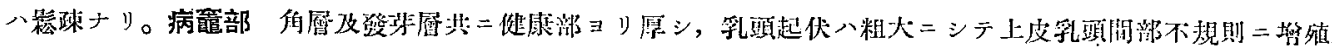

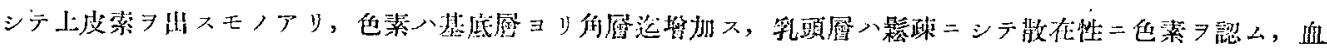

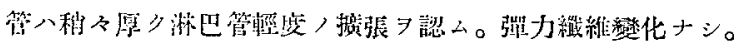

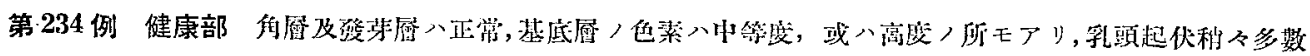

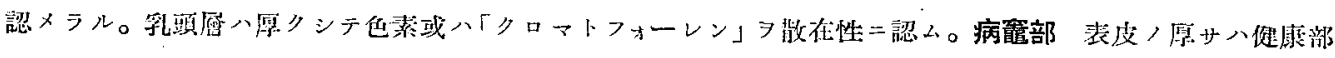

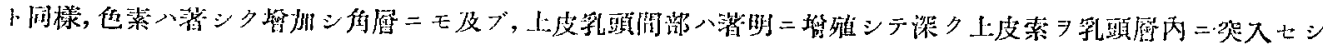

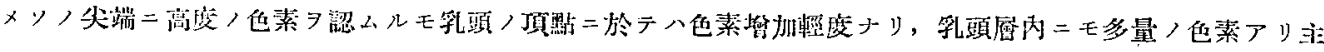

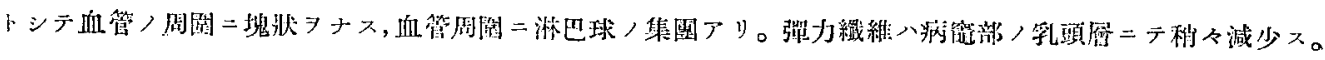

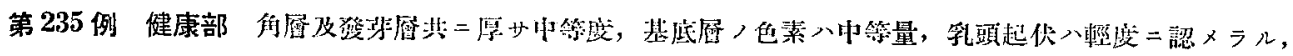

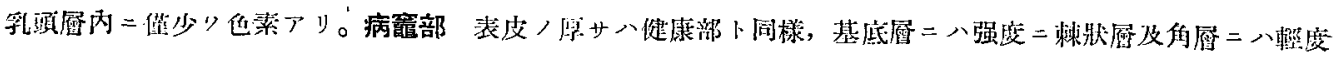

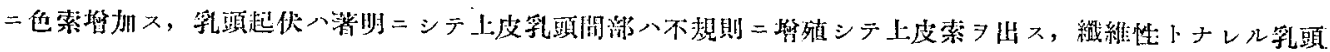

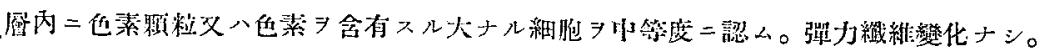

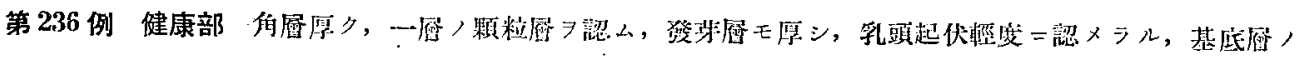

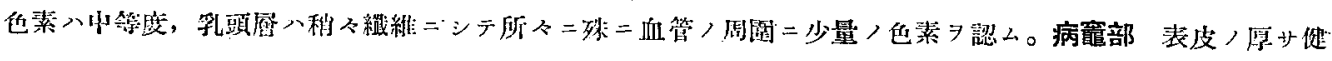

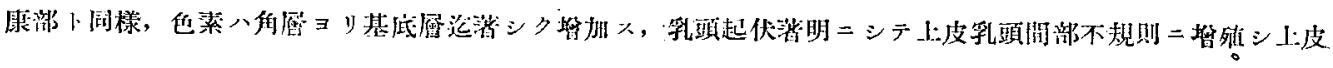




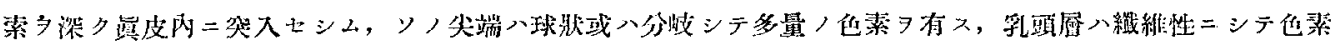

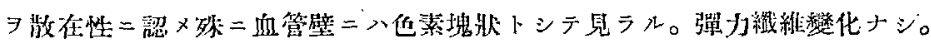

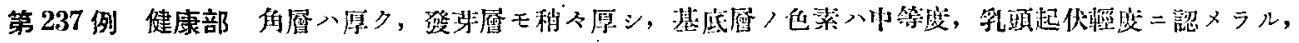

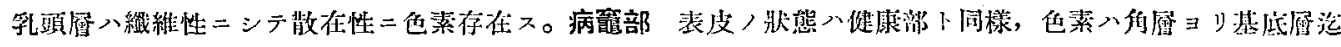

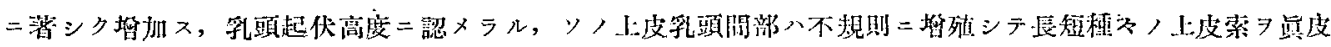

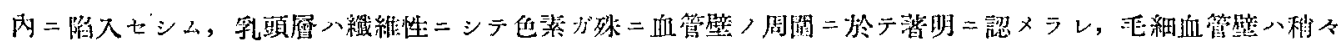

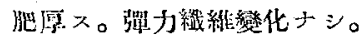

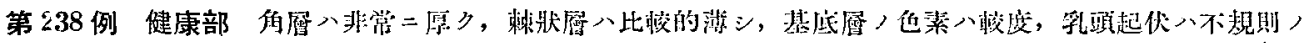

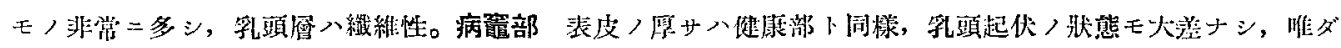

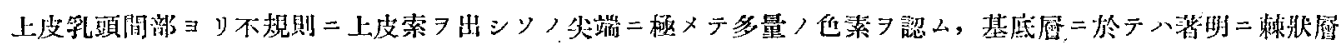

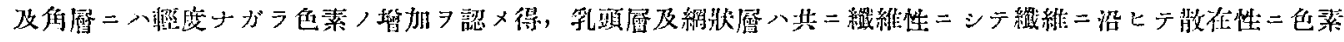

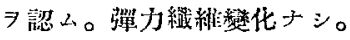

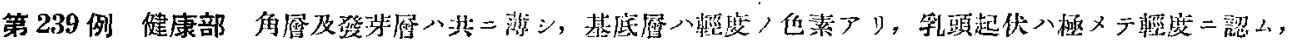

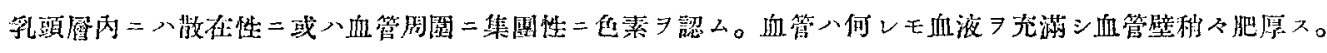

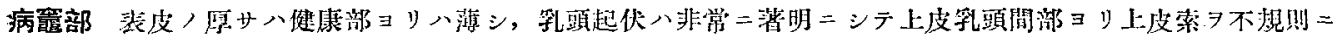

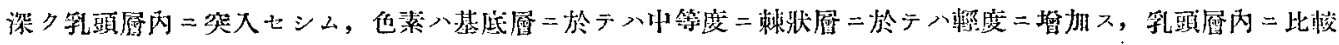

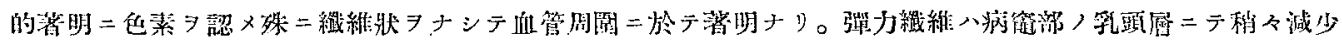
过曲, 或煌火入。

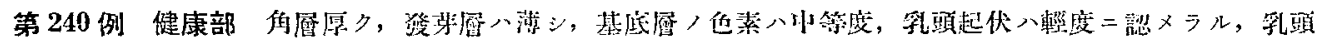

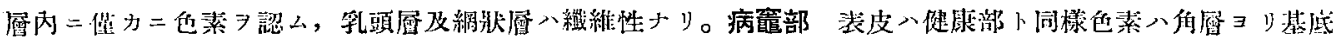

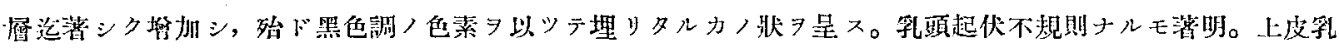

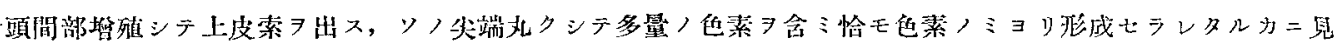

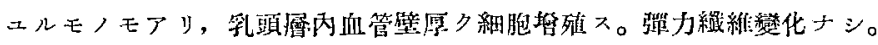

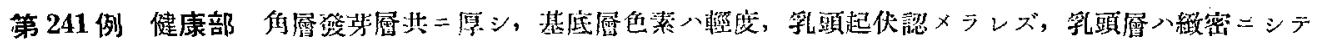

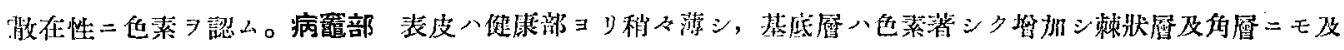

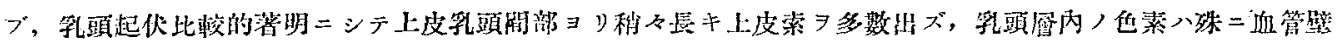

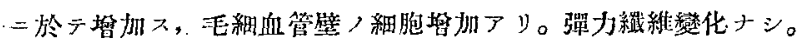

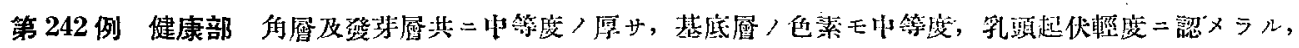

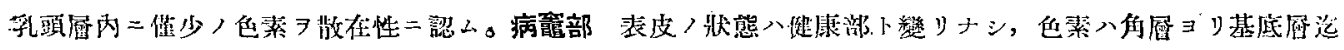

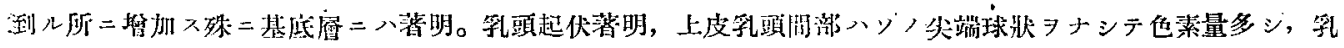

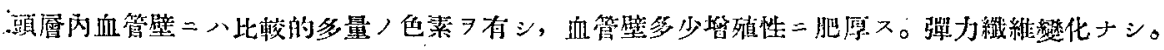

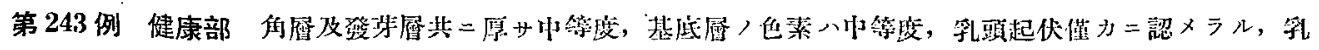

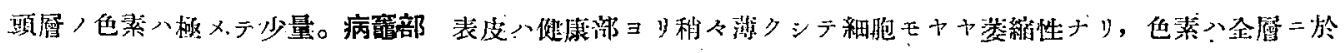

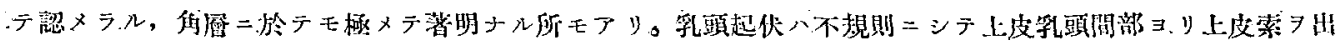

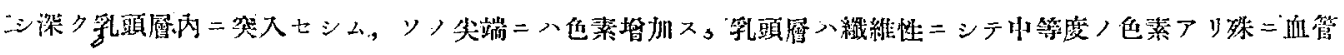




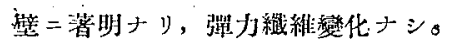

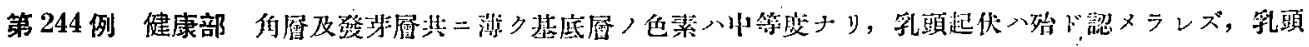

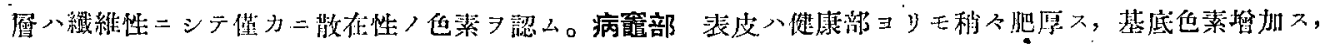

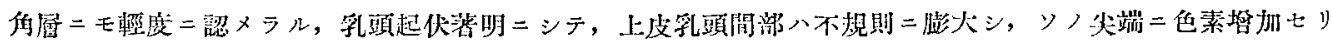

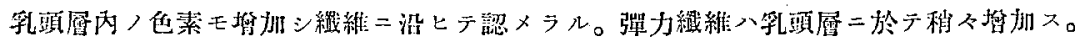

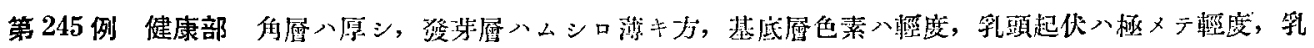

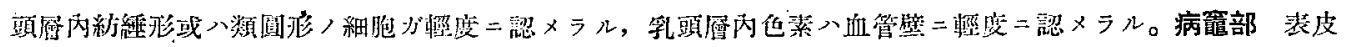

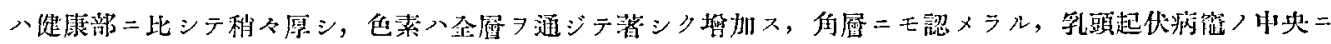

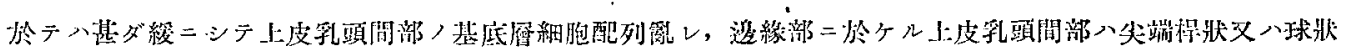

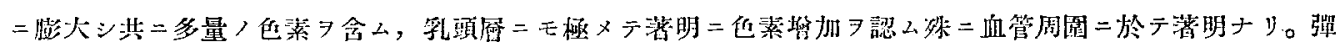

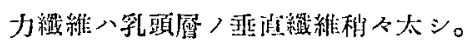

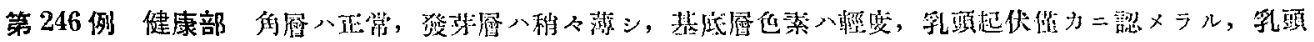

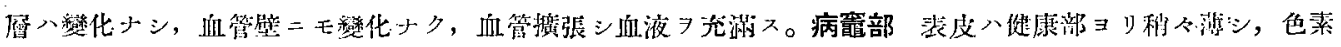

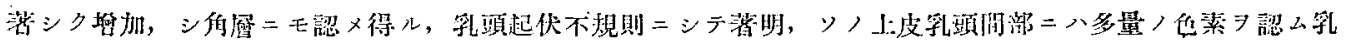

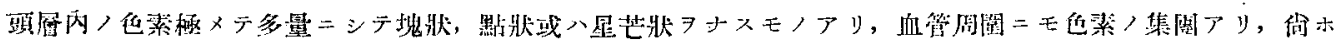

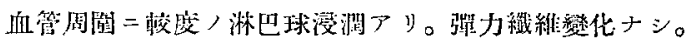

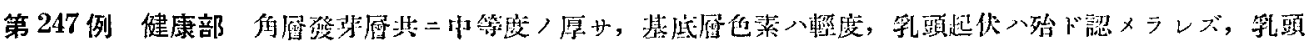

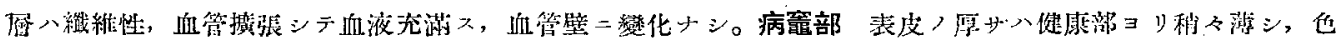

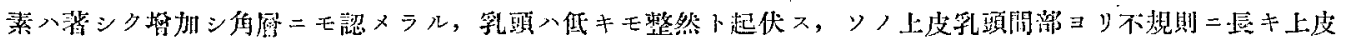

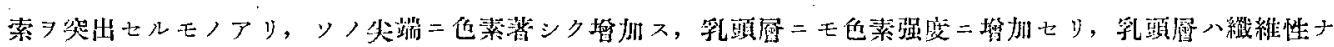

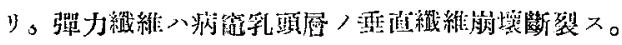

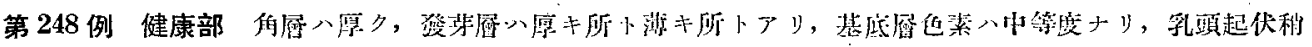

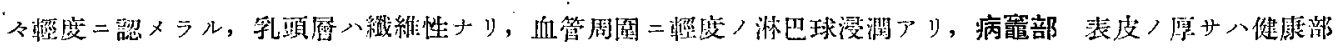

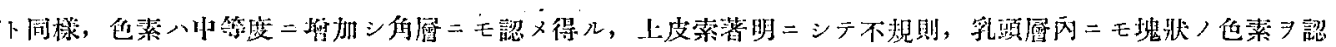

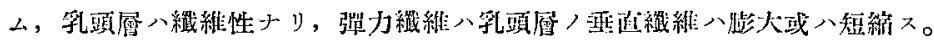

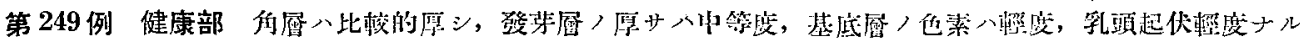

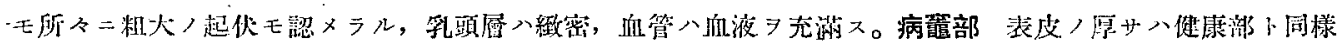

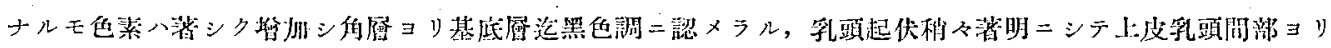

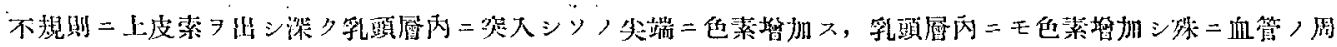

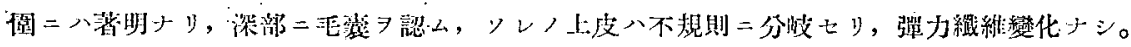

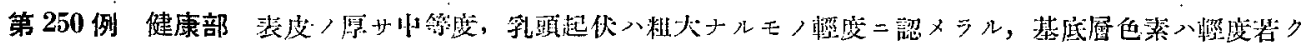

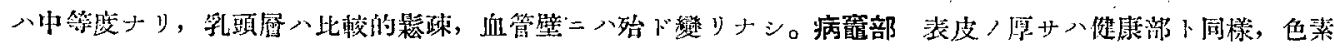

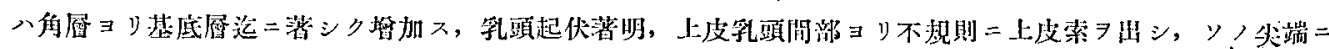

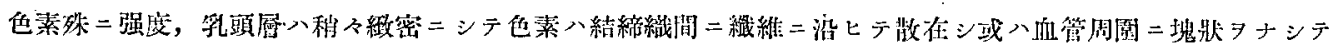

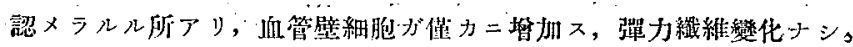




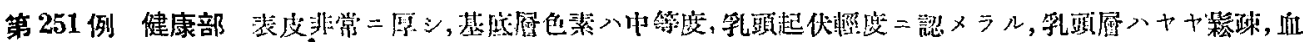

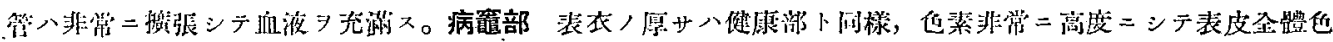

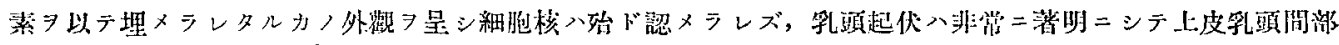
ヨリ上皮䇣

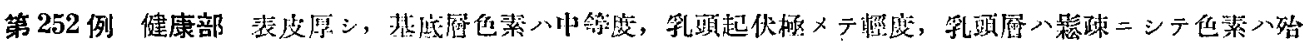

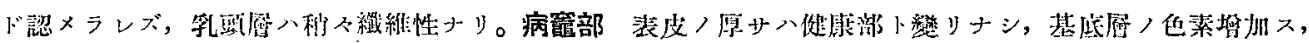

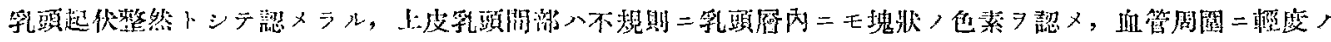

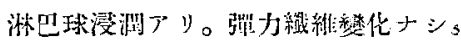

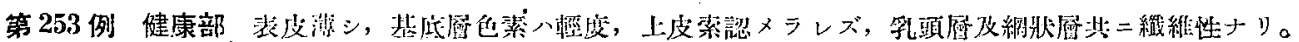

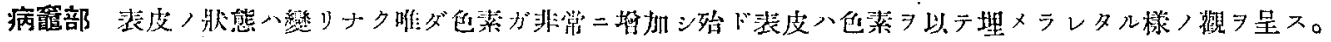

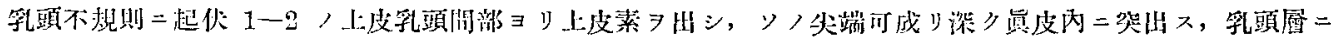

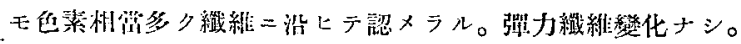

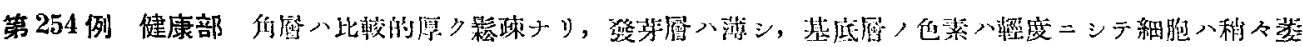

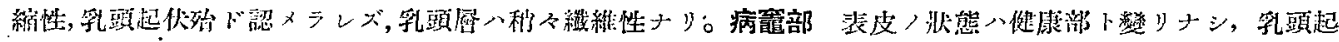

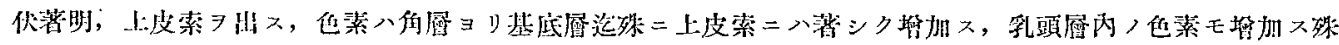

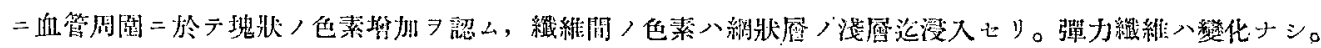

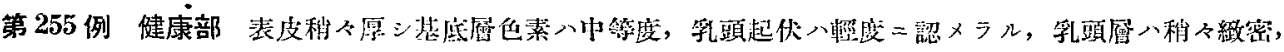

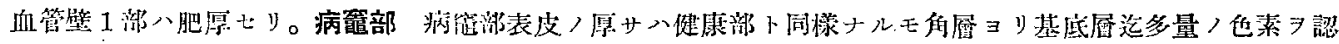

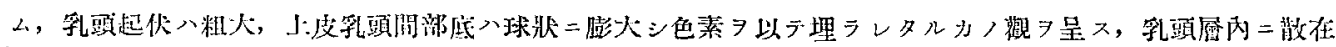

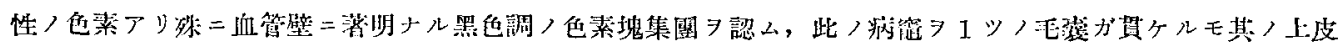

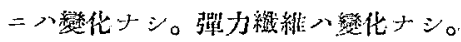

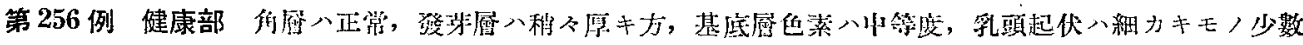

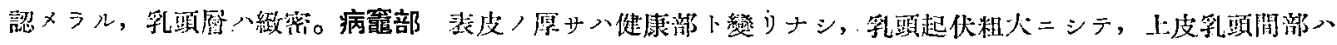

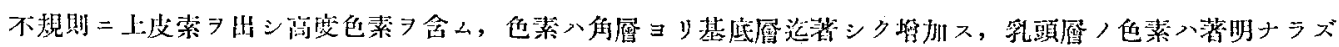

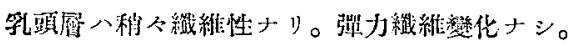

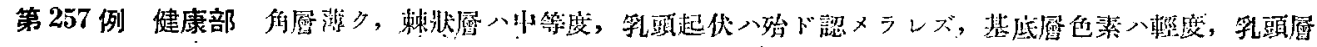

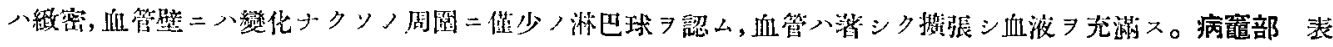

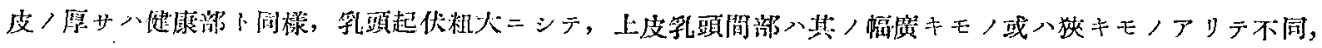

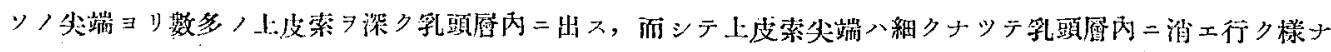

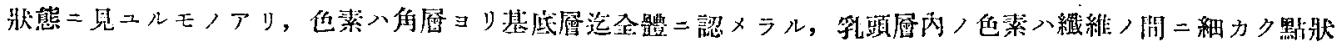

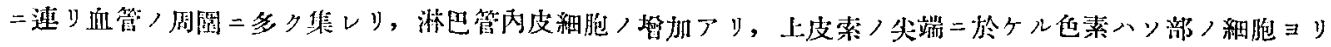

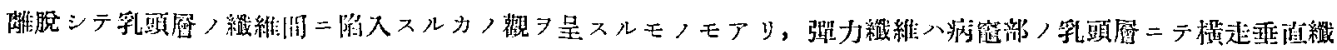
維共二減少セり。

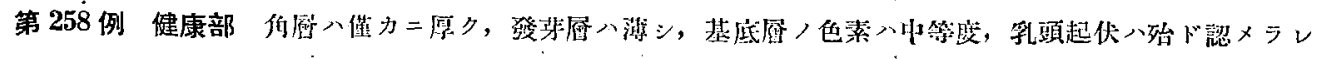

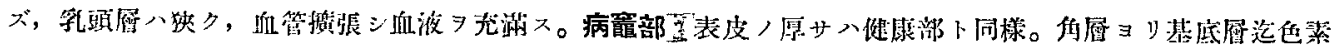




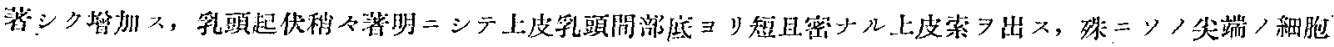

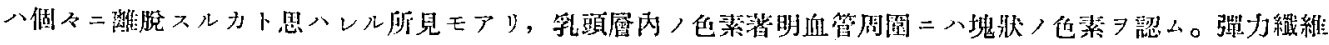
遂化ナシ。

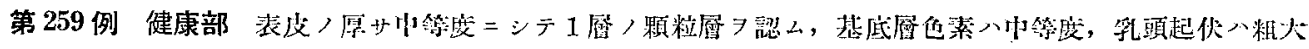

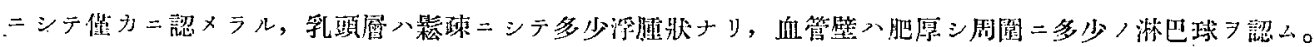

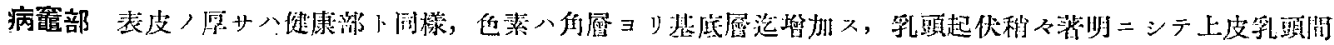

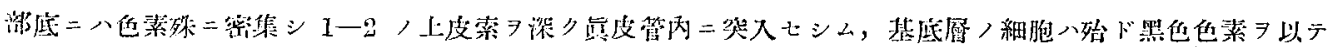

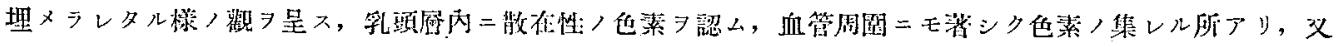

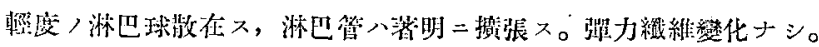

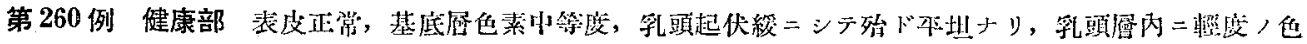

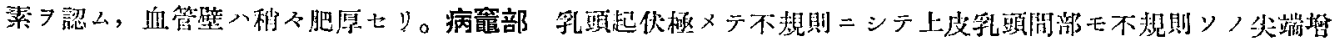

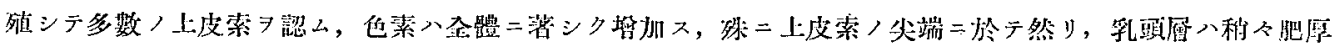

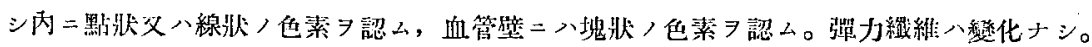

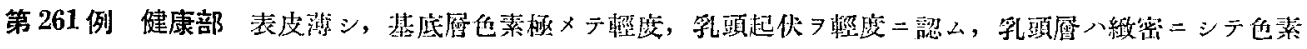

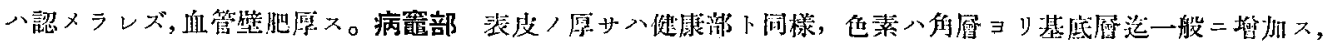

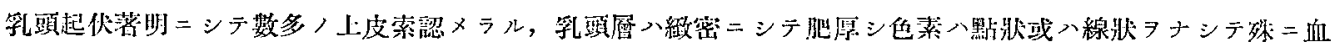

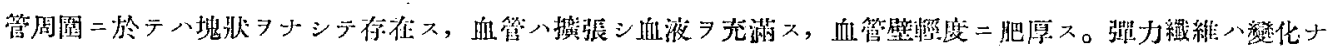
シ。

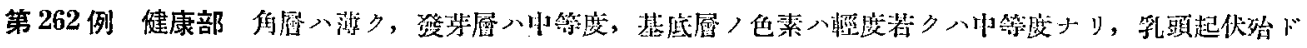

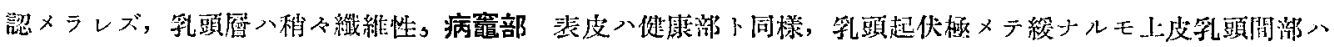

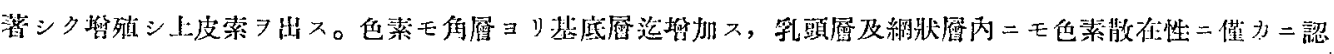

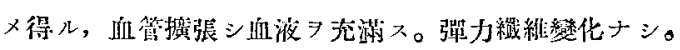

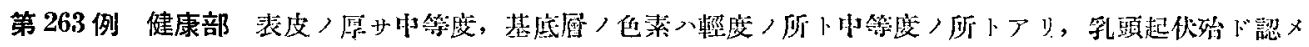

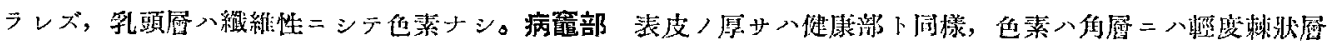

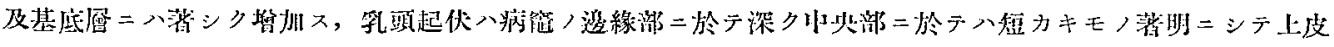

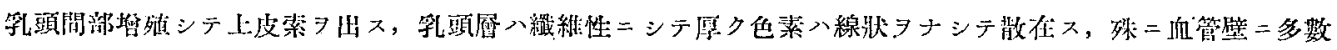

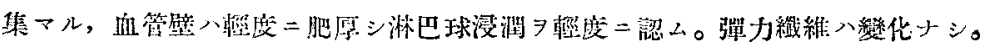

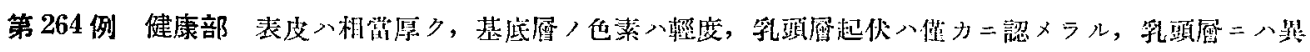

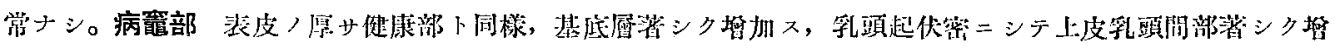

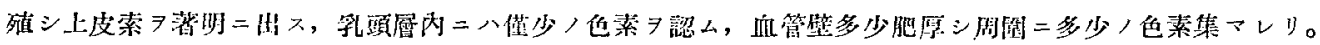
㗆力緎維變化ナシ。

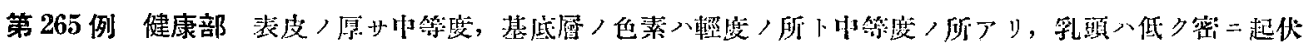

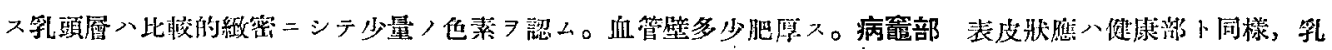

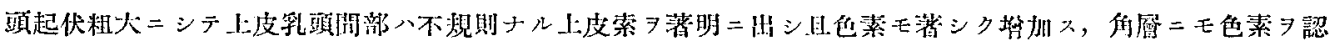

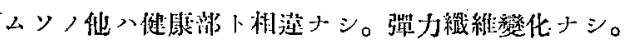




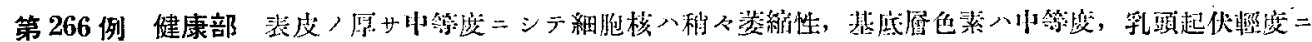

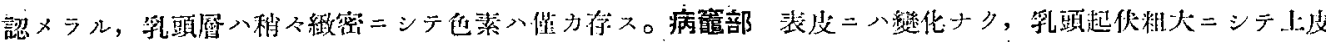

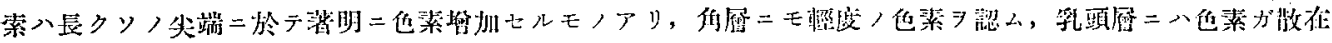

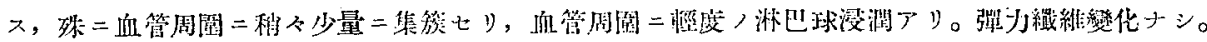

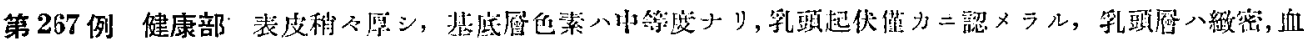

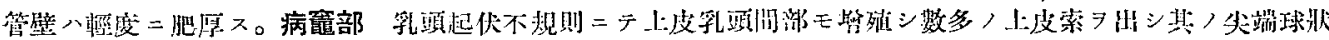

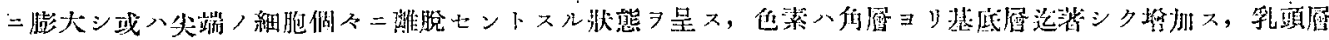

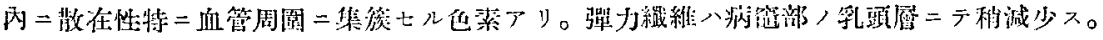

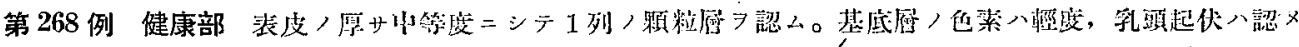

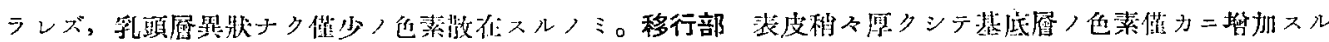

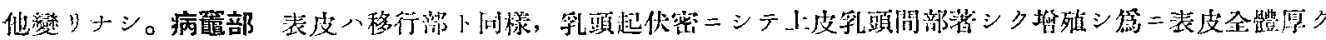

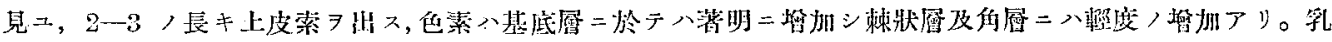

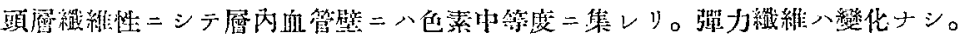

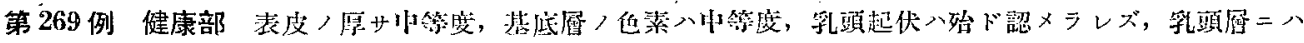

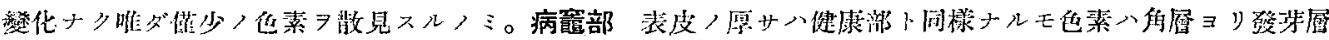

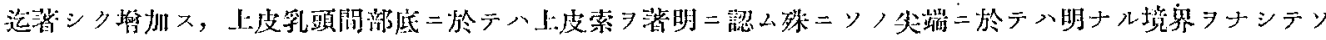

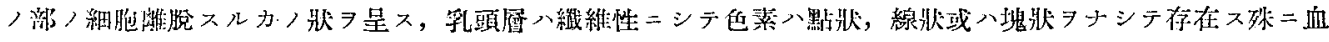

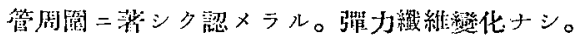

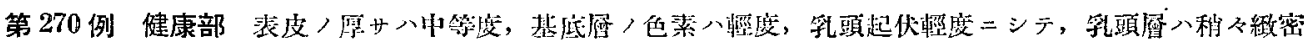

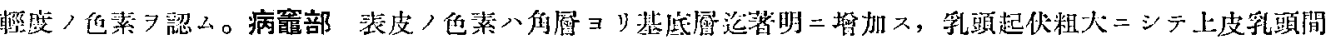

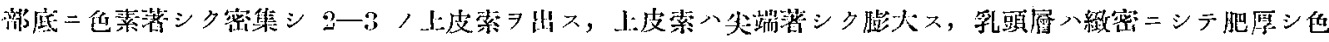

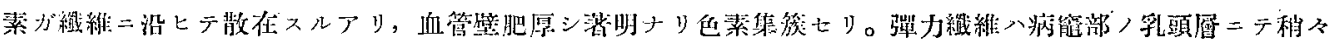
娍少入。

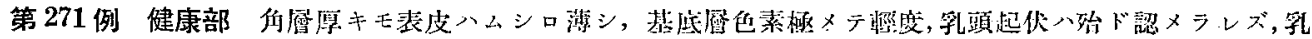

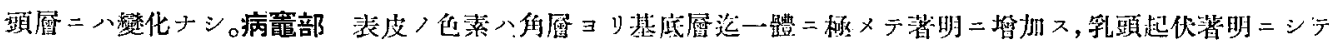

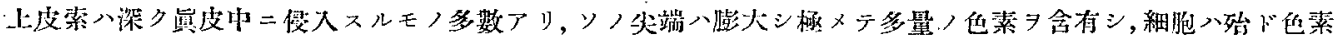

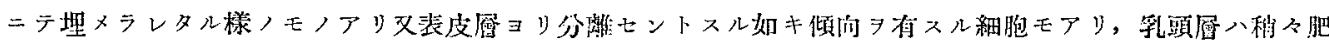

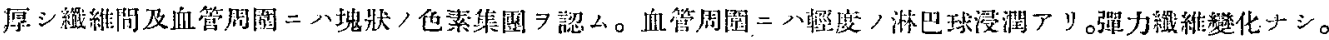

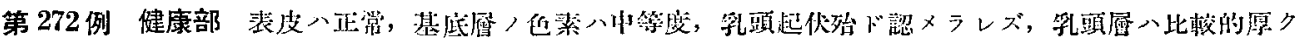

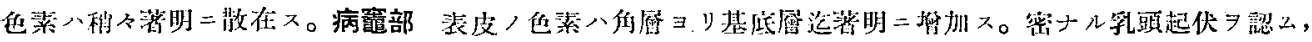

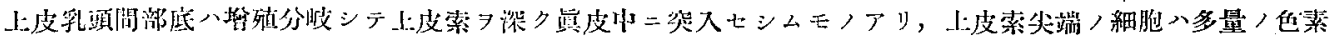

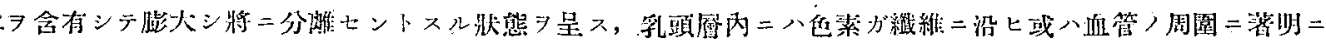

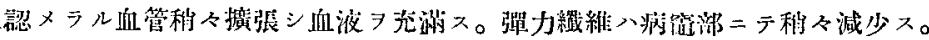

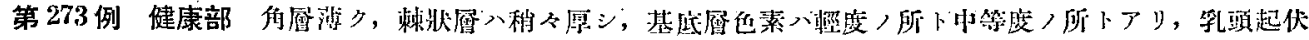

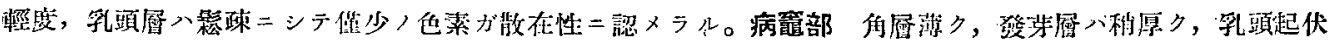




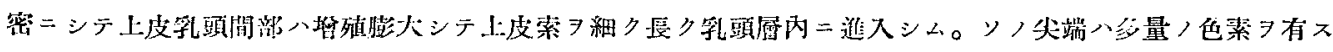

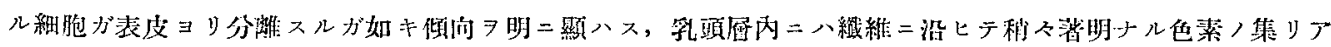

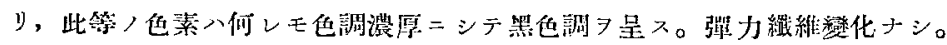

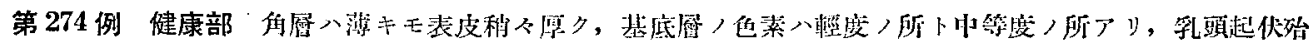

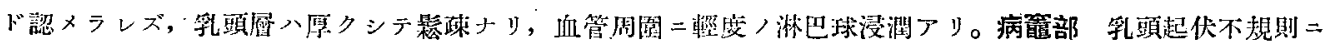

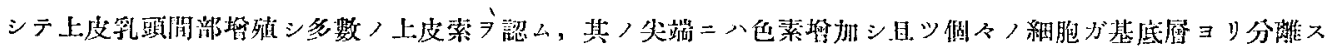

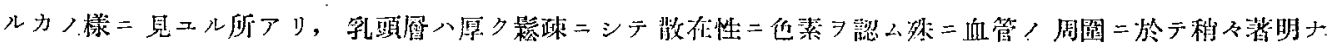

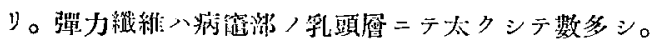

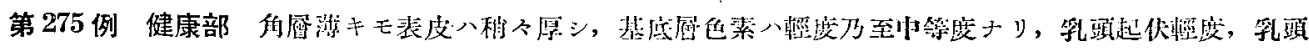

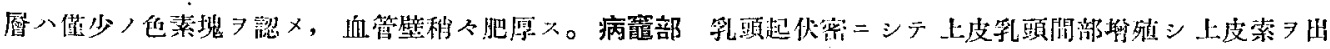

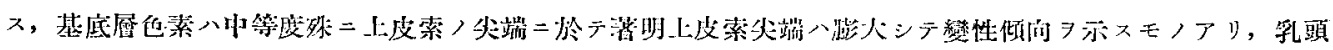

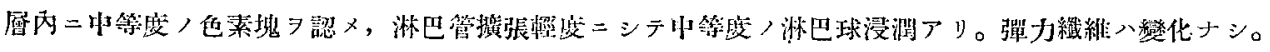

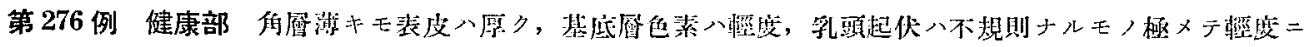

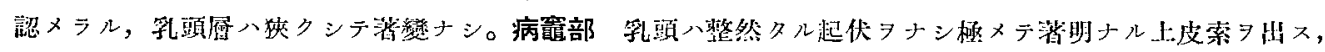

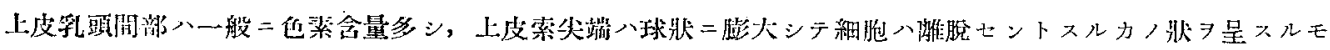

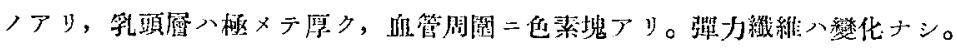

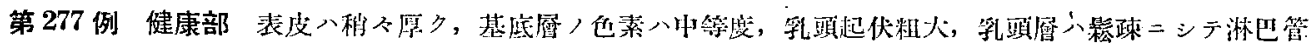

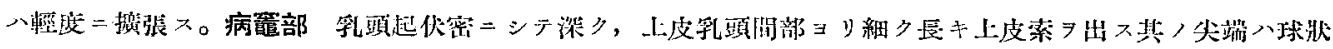

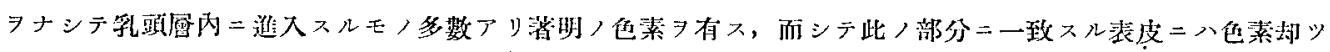

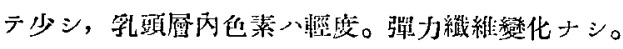

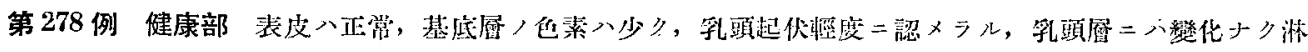

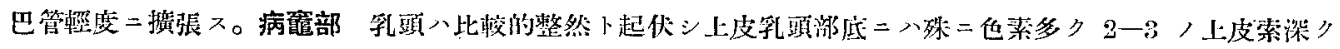

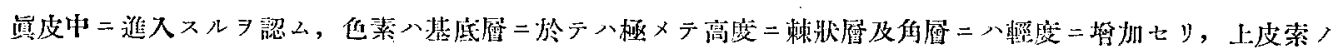

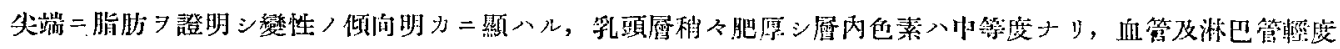

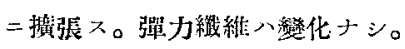

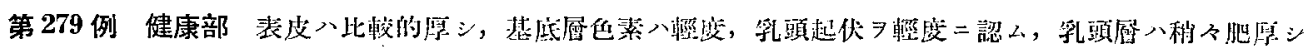

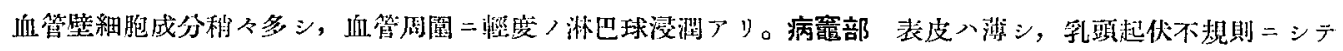

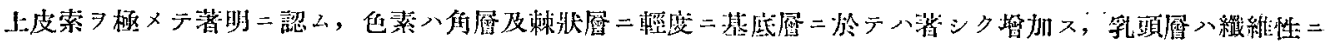

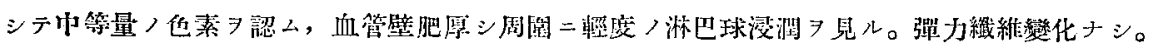

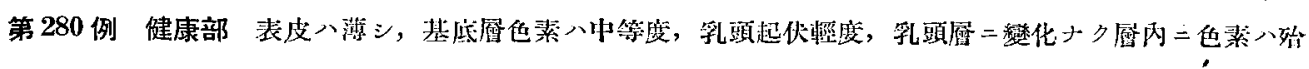

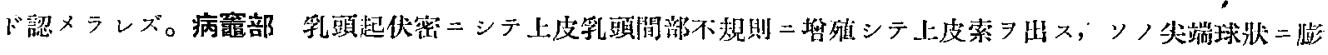

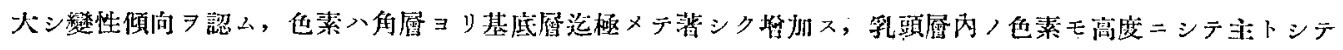

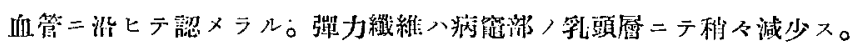

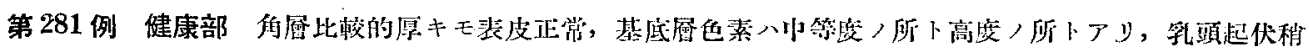

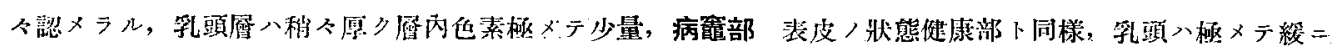




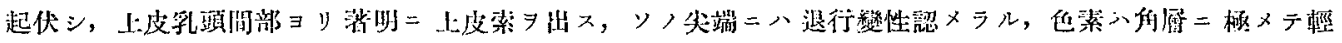

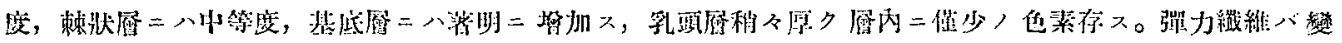
化ナシ。

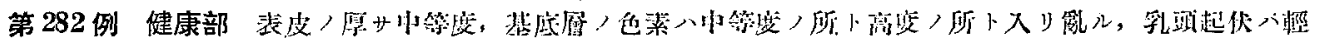

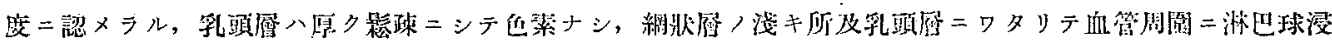

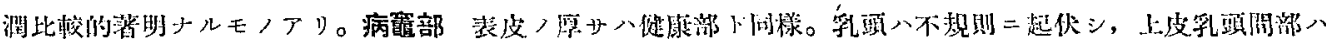

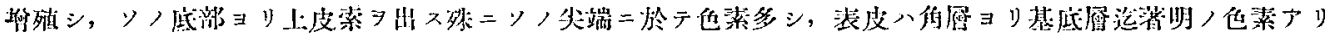

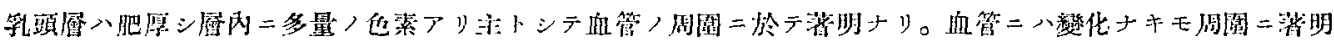

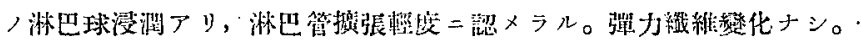

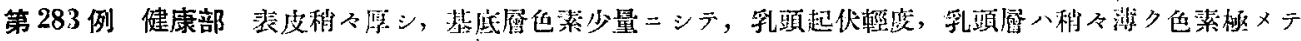

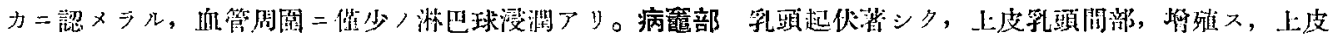

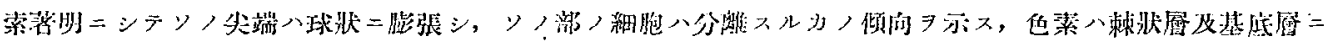

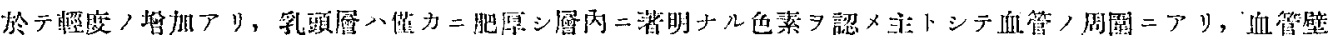

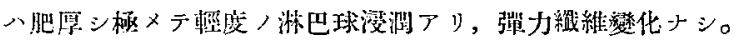

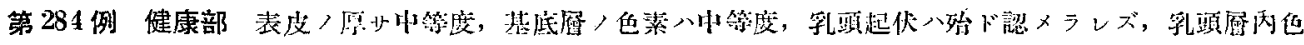

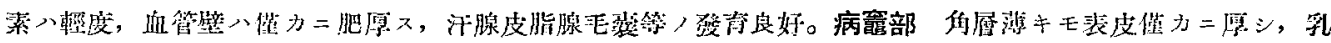

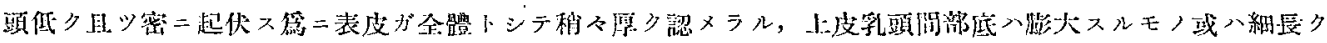

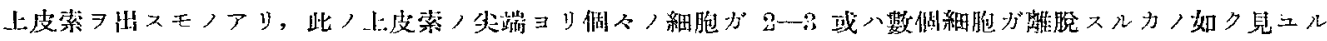

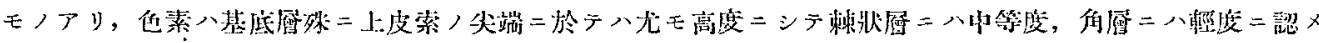

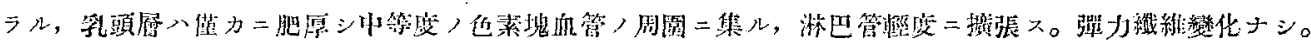

\section{6. 第六型}

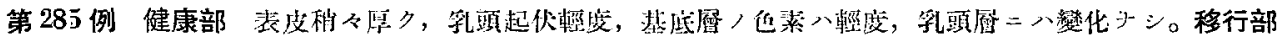

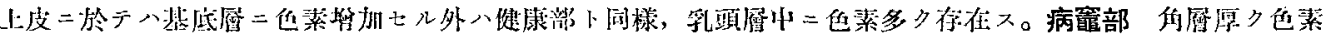

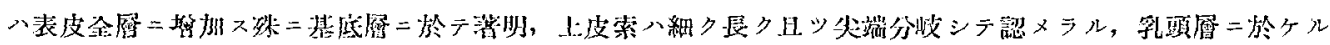

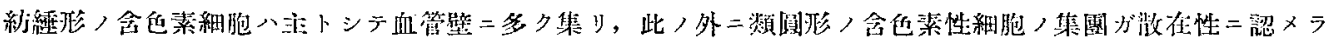
ル。彈力䄉維戀化ナシ。

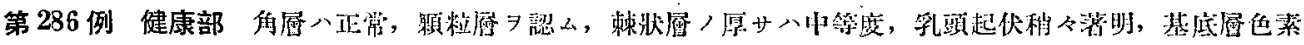

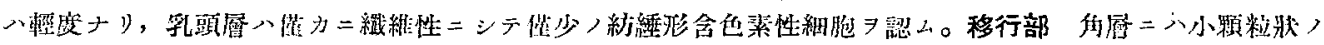

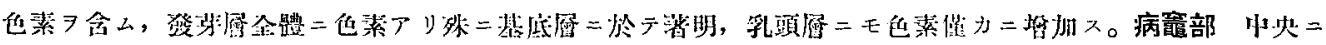

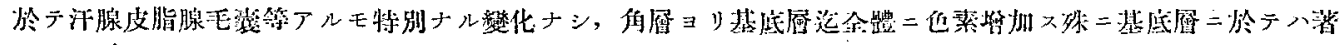

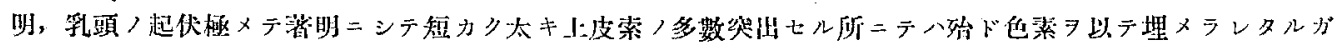

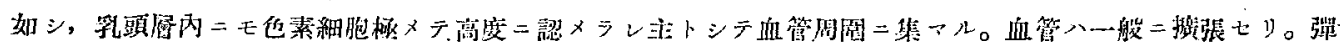
力䋊維八變化ナシ。

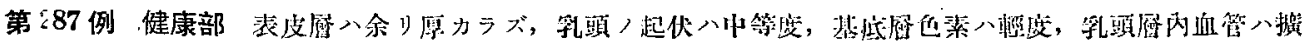

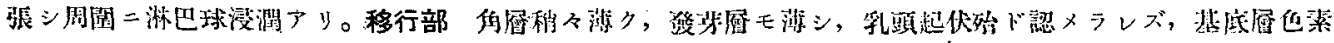




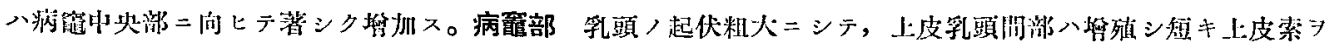

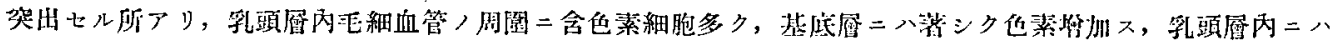
巴素少シ。强力饿維八變化ナシ。

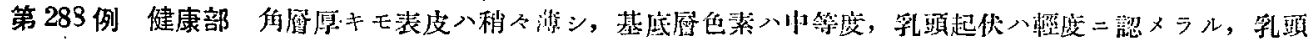

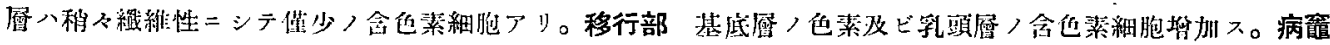

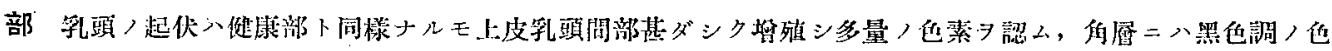

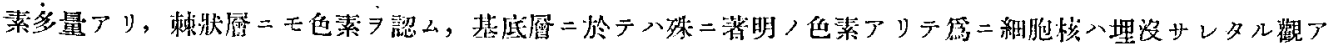

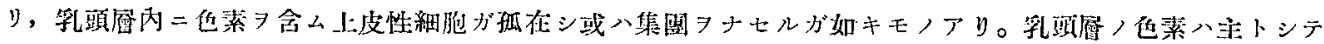

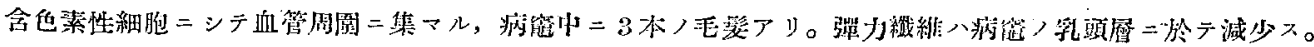

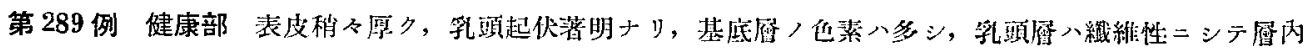

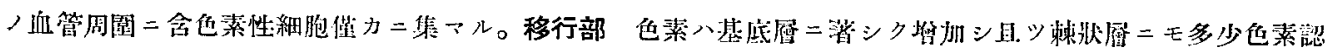

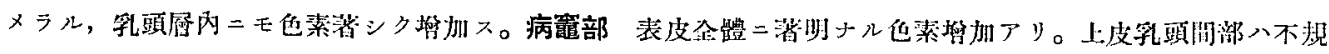

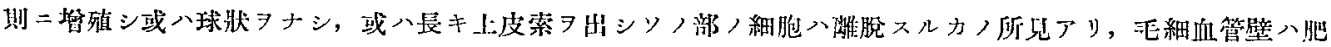

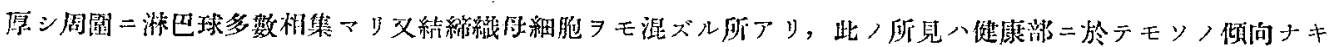

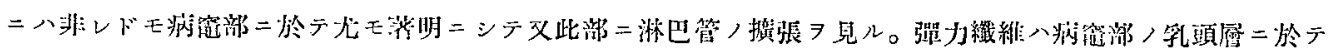

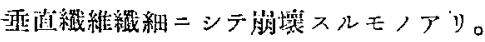

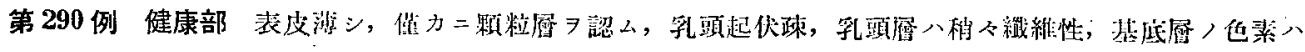

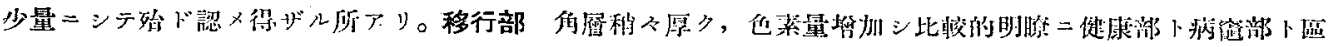

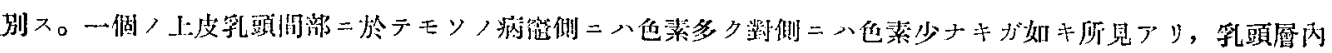

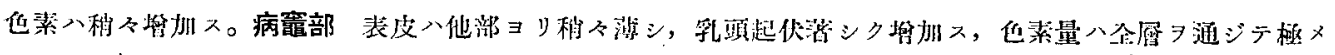

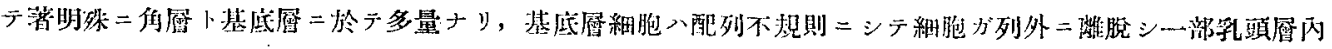

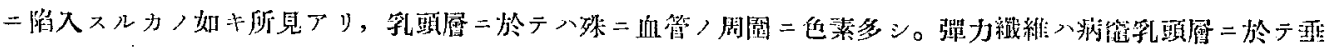

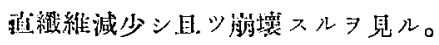

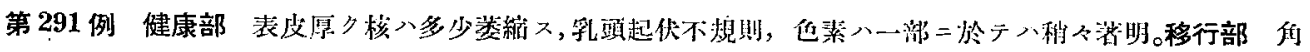

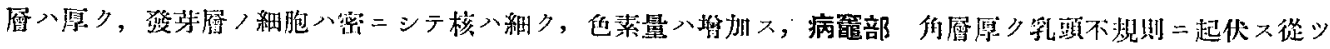
テ表皮ノ表面凹凹

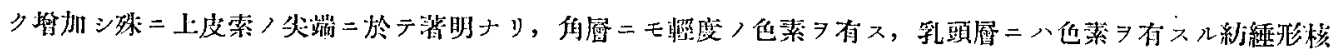

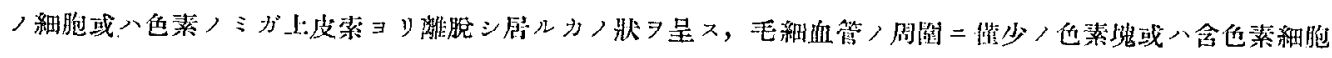

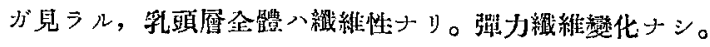

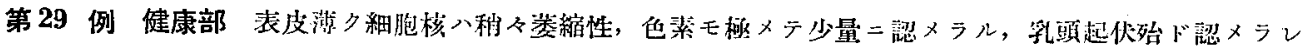

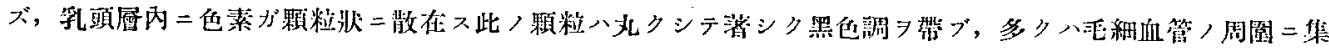

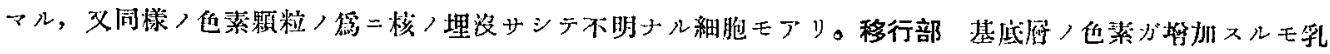

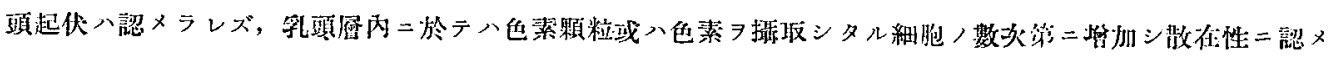

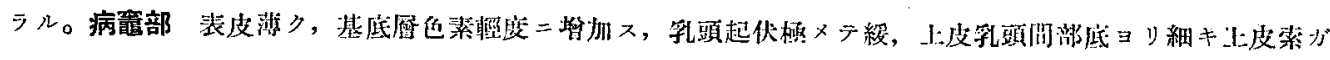

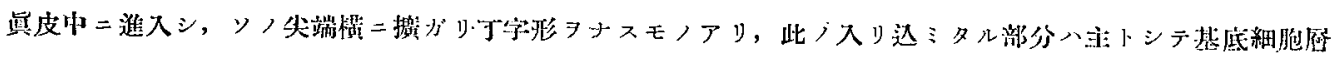




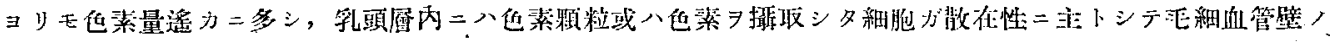

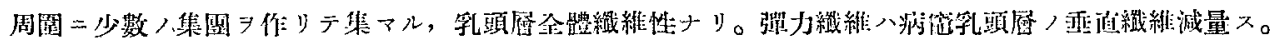

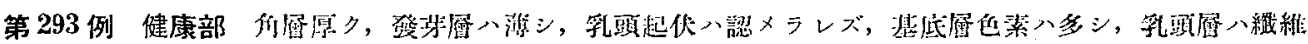

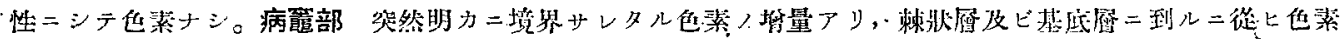

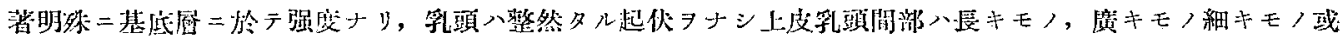

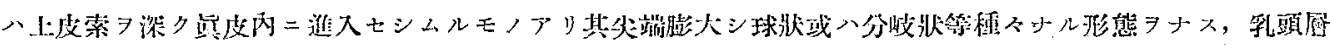

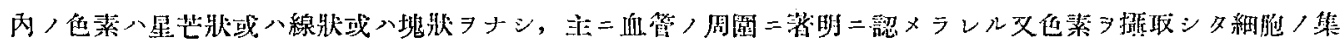

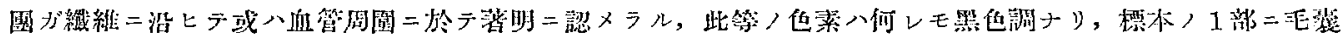

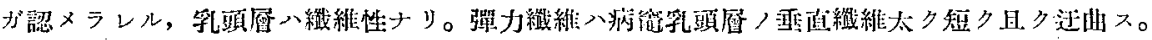

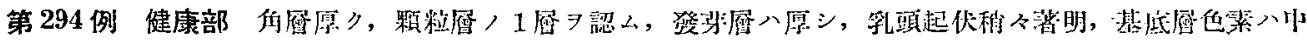

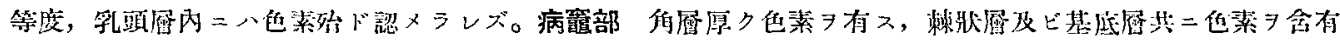

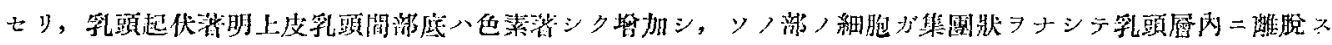

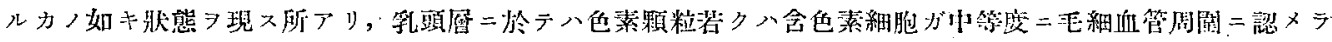

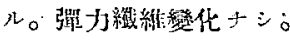

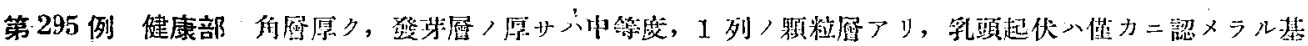

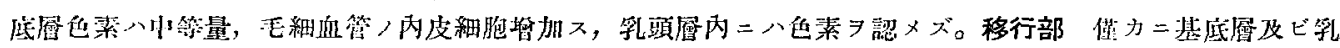

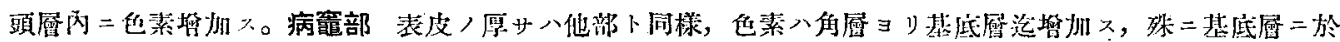

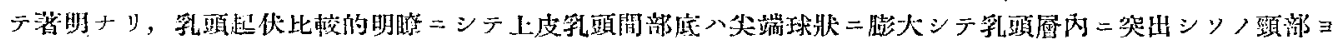

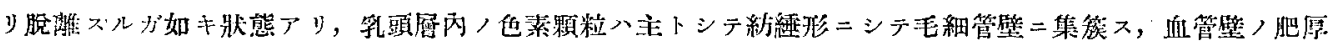

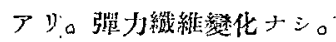

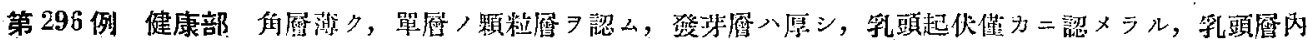

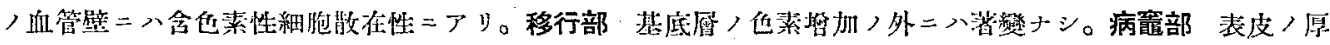

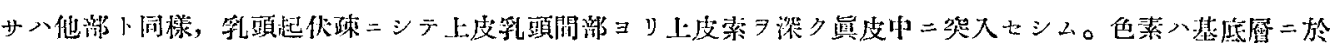

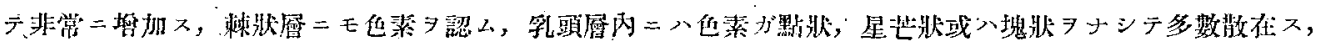

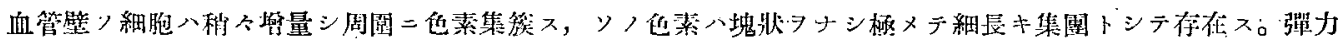

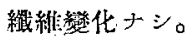

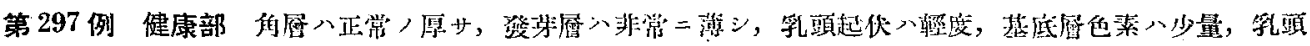

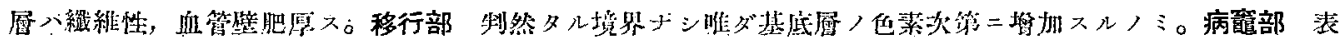

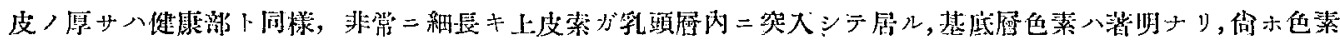

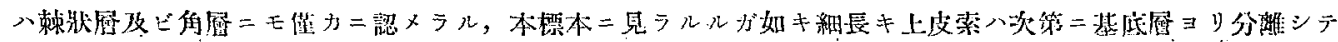

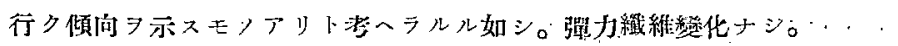

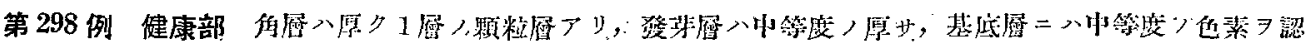

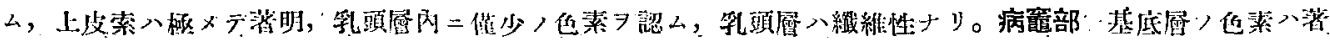

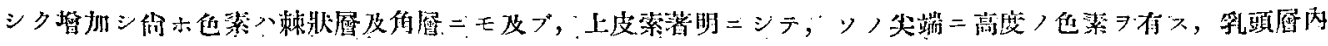

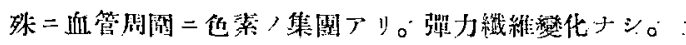




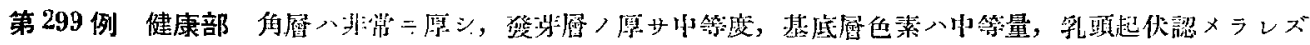

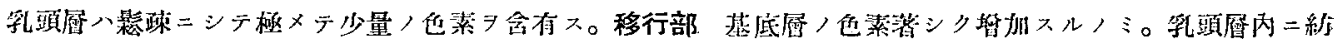

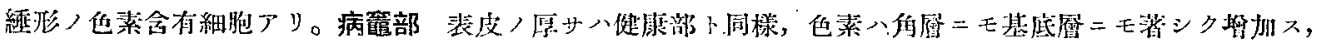

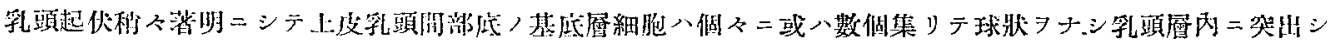

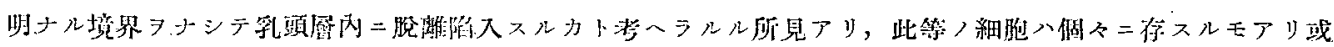

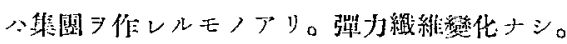

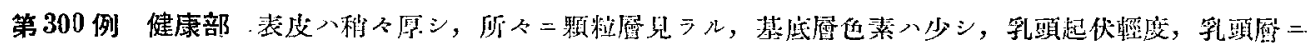

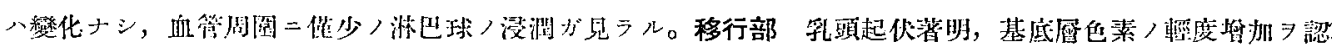

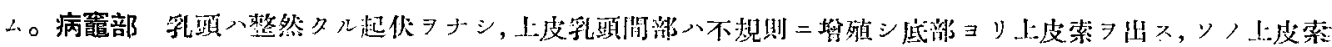

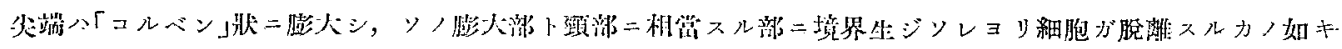

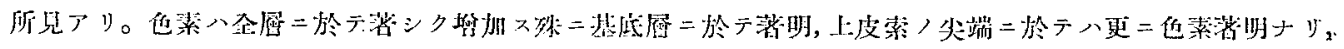

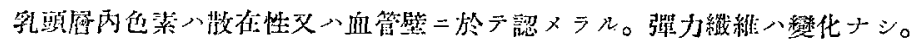

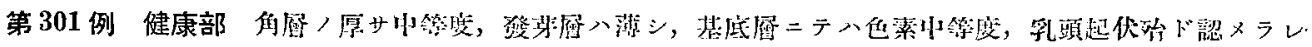

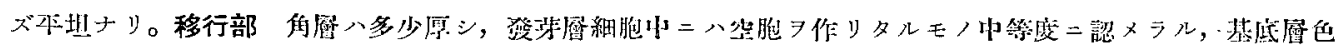

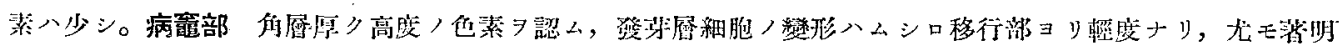

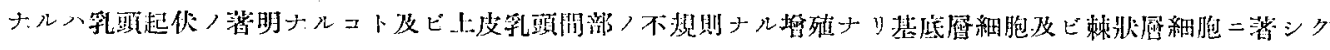

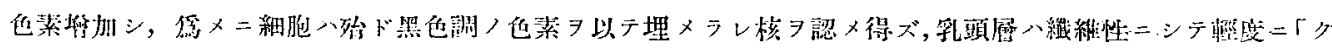

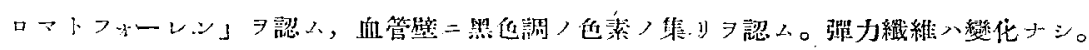

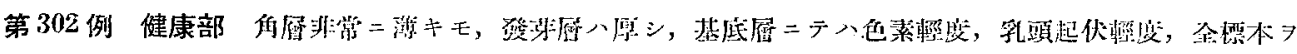

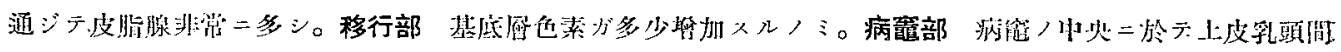

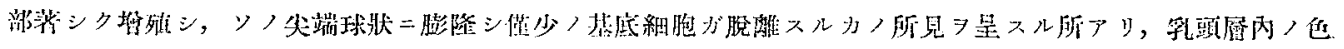

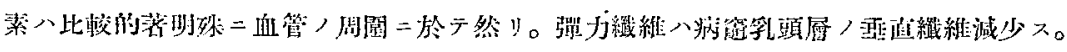

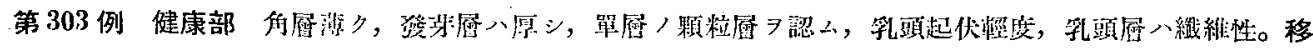

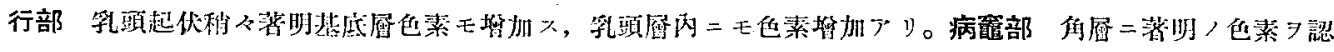

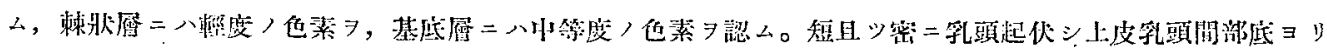

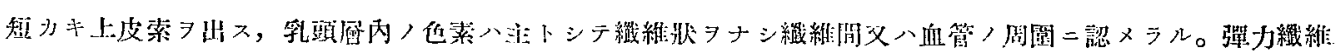
變化ナシ。

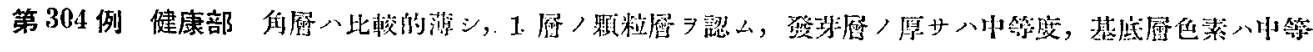

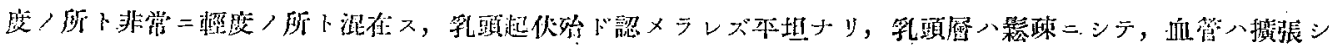

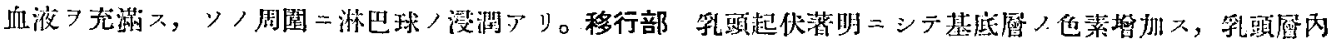

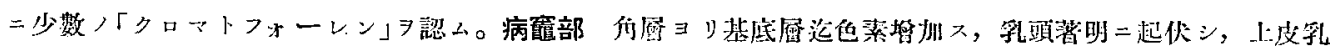

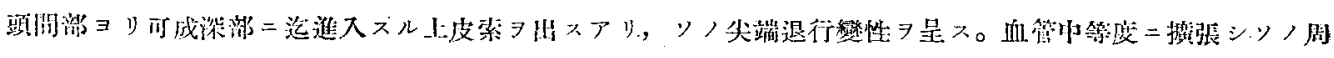

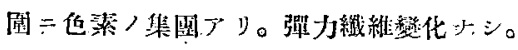

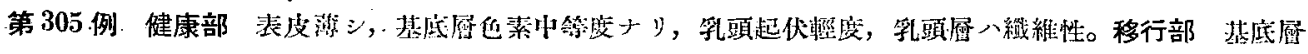

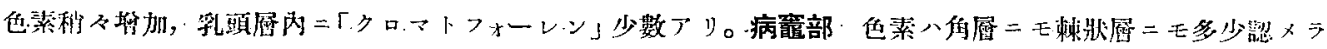




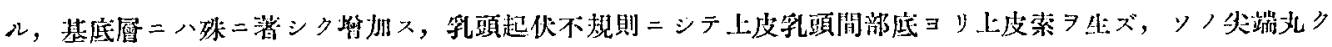

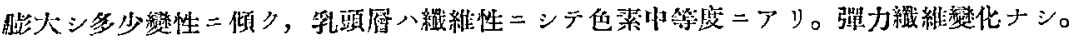

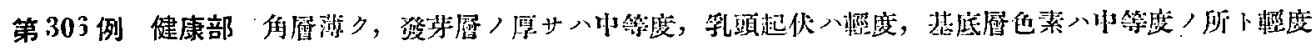

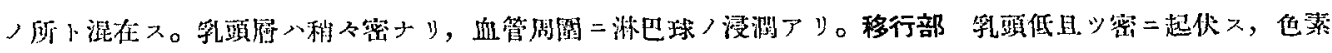

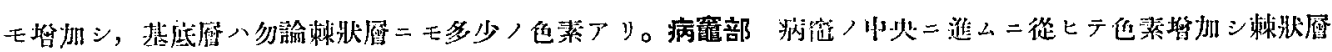

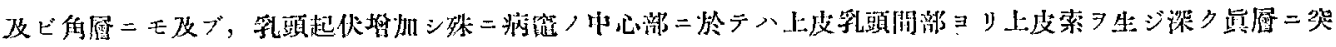

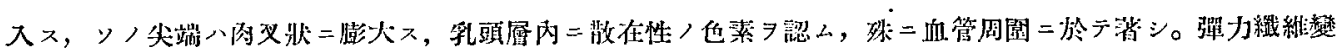
化ナシ。

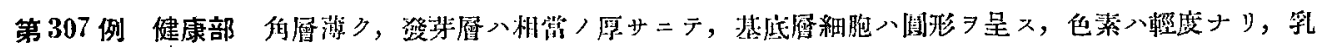

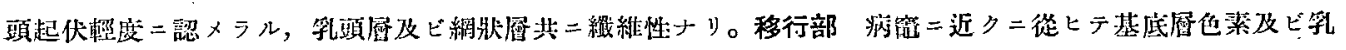

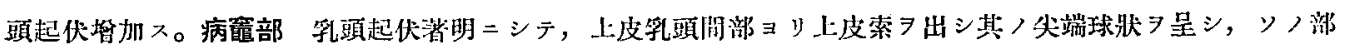
，細咆離㧤スルガ如キ状热 維橎化ナ゙シ。

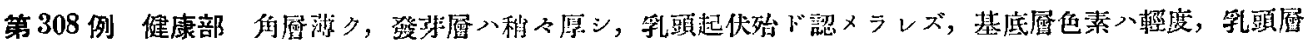

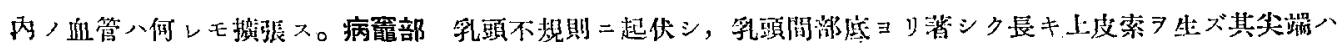

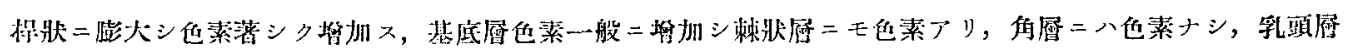

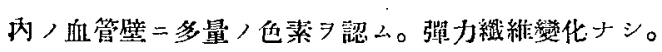

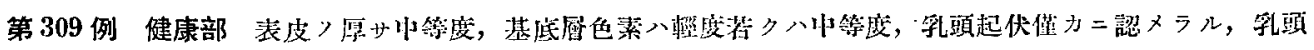

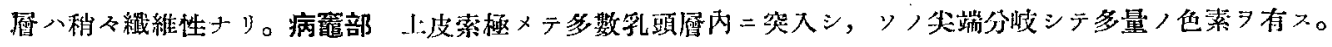

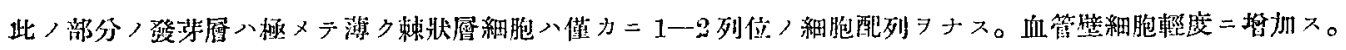

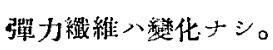

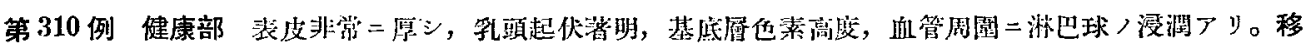

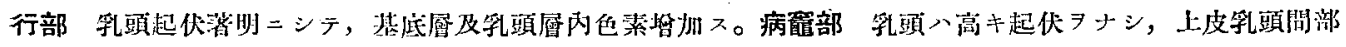

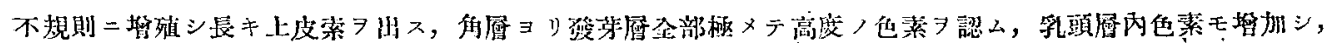

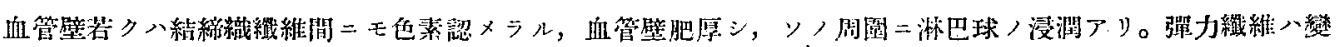
化ナシ。

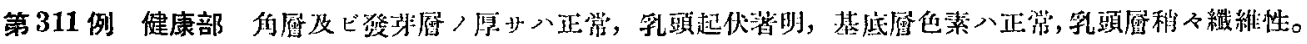

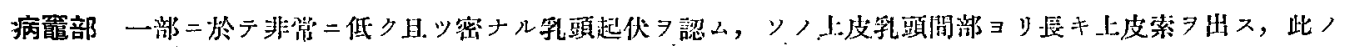
蔀二於テ色菜非常二鸤加

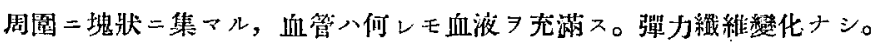

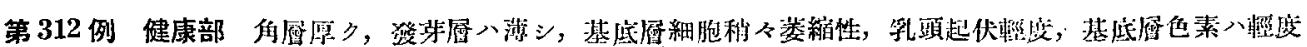

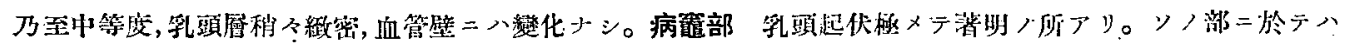

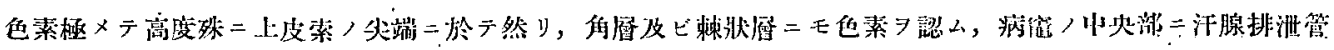

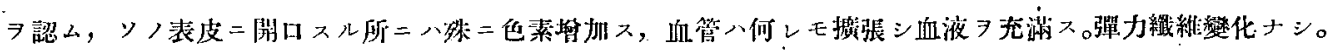

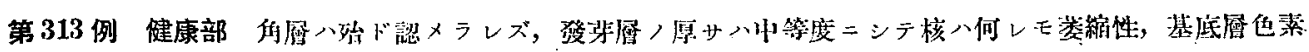




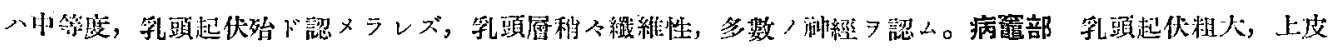

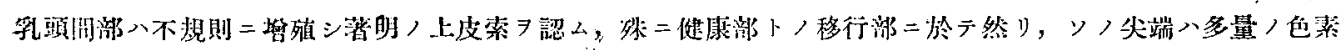

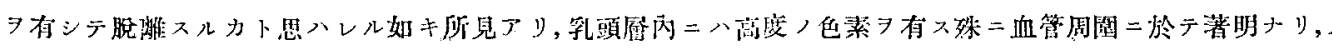

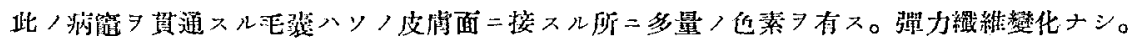

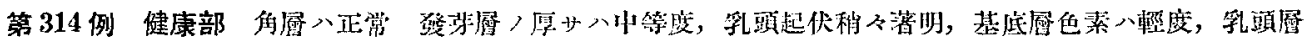

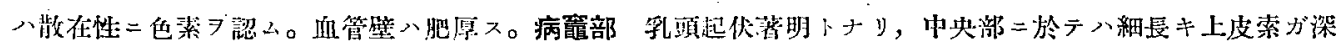

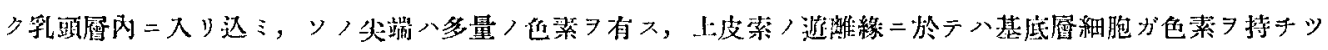

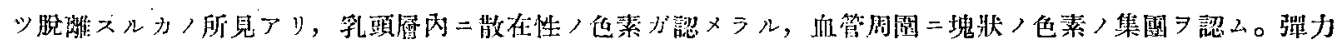

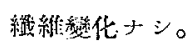

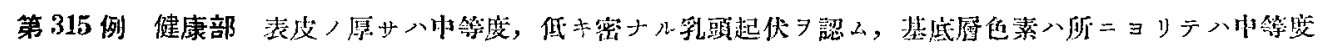

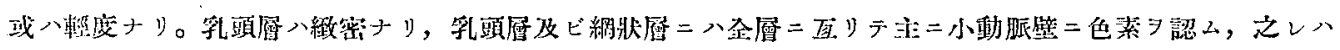

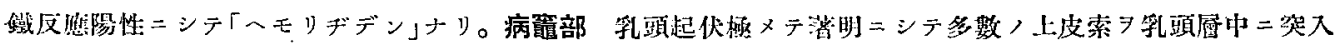

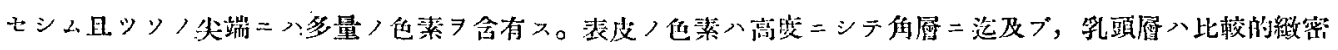

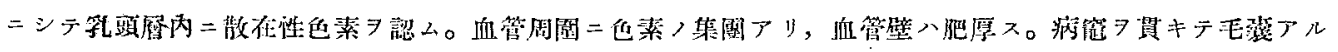

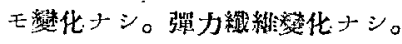

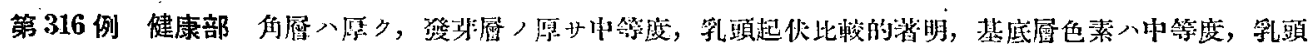

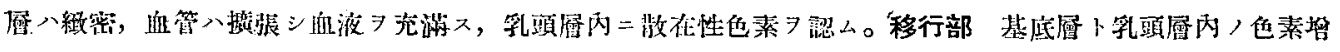

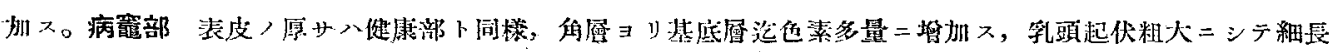

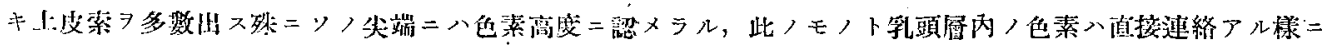

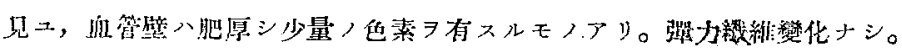

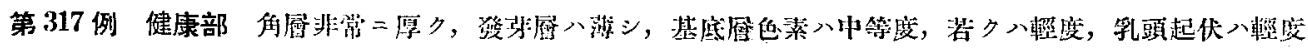

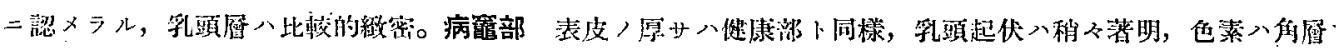

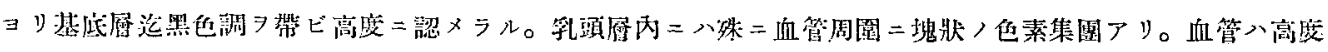

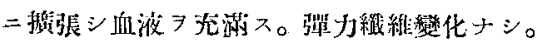

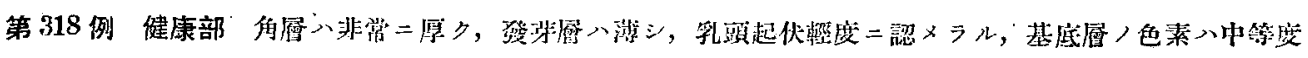

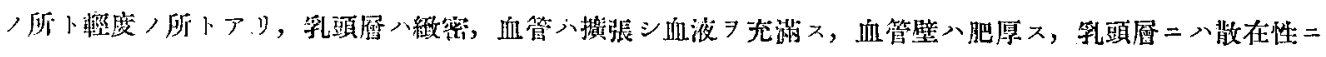

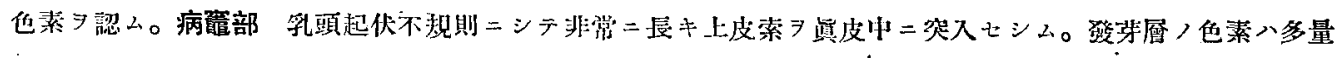

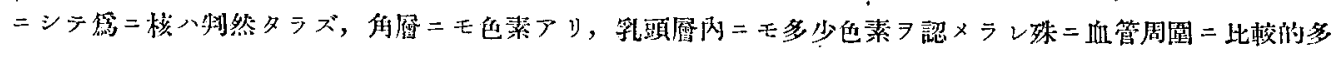

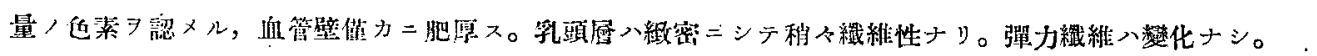

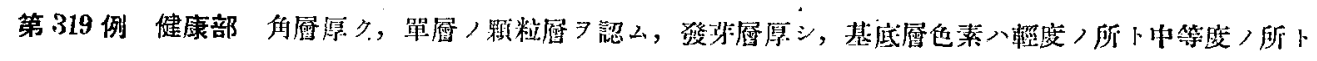

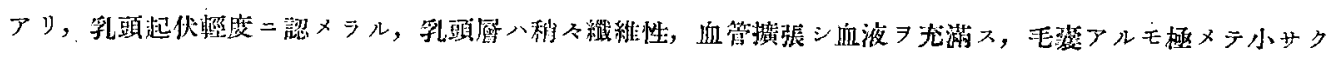

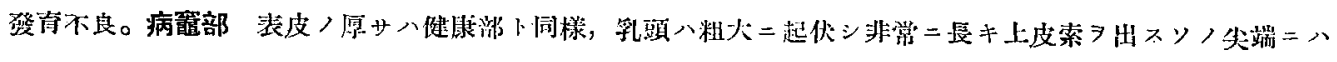

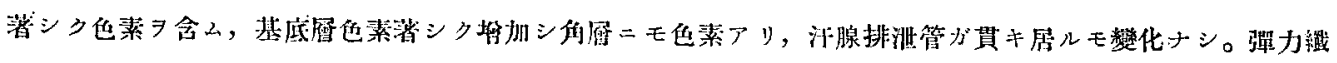

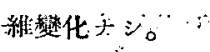

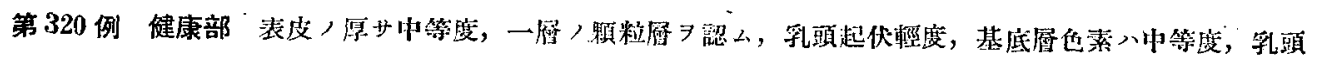




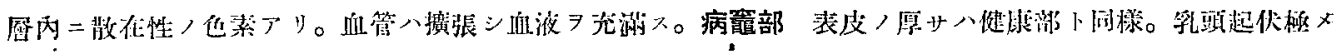

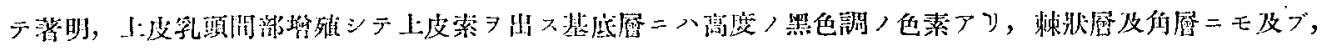

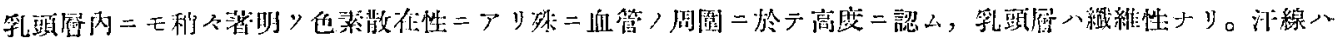

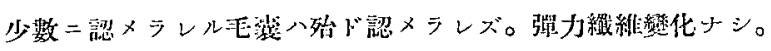

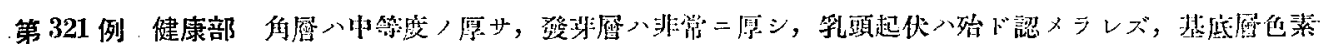

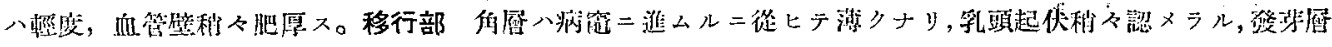

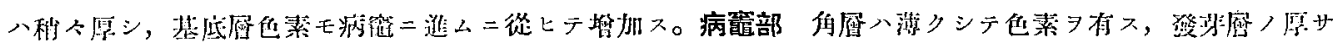

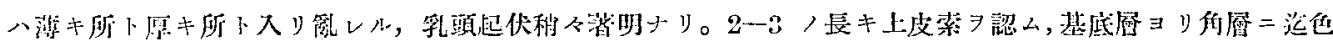

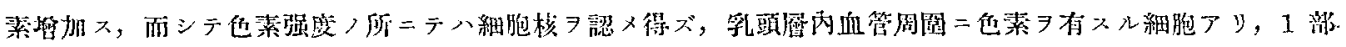

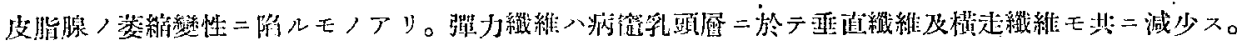

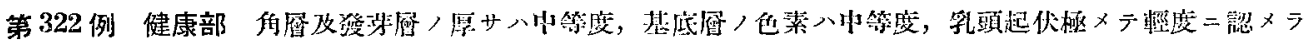

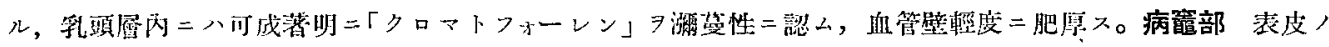

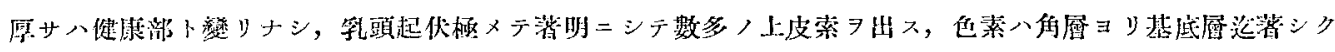

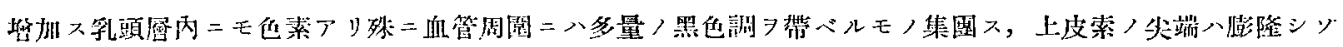

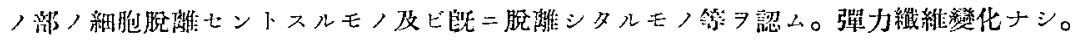

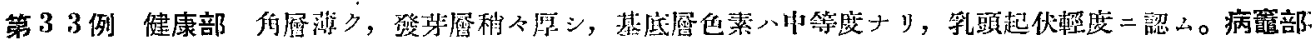

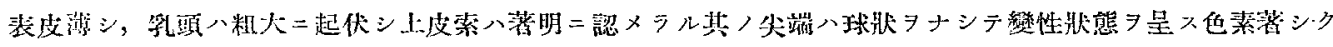
篔加 緎維然化于シ。

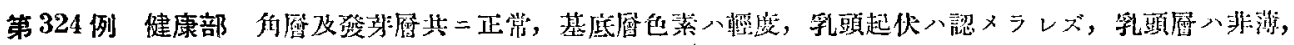

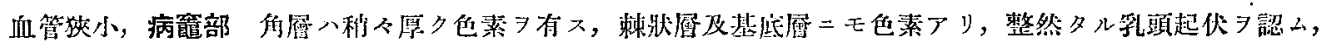

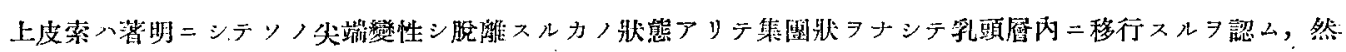

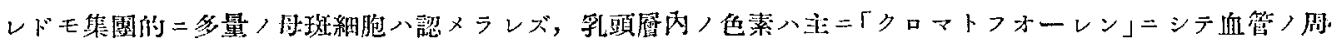

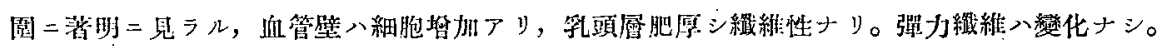

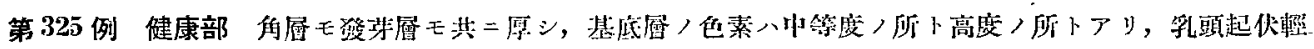

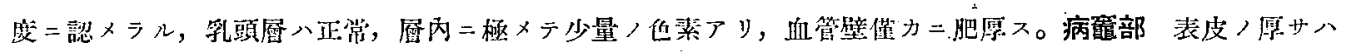

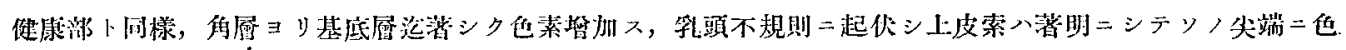

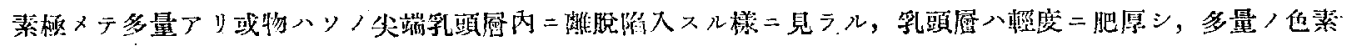

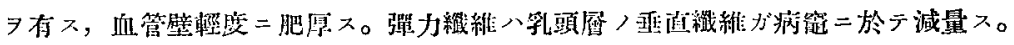

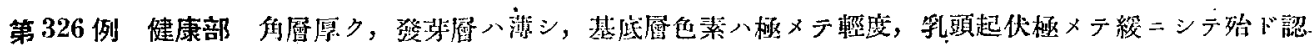

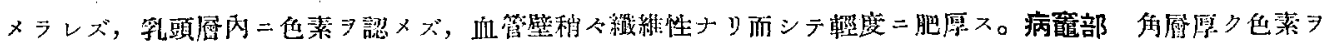

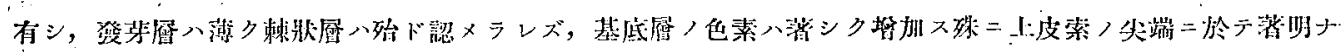

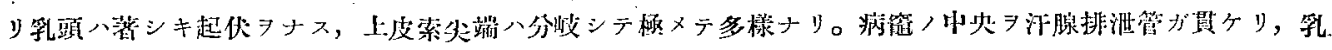

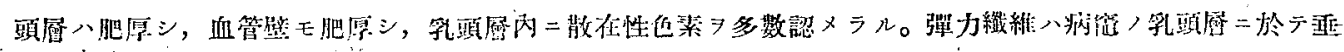

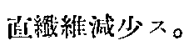




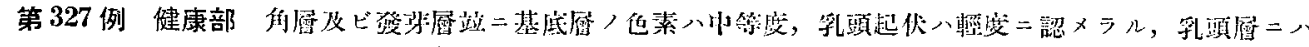

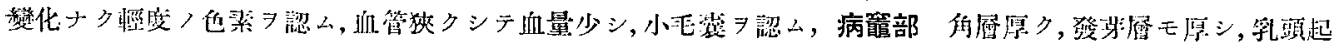

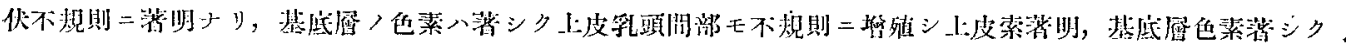

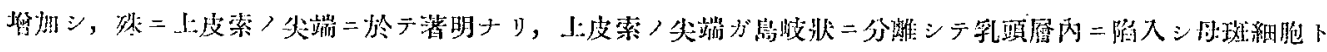

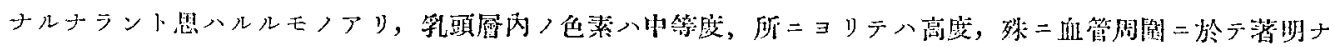

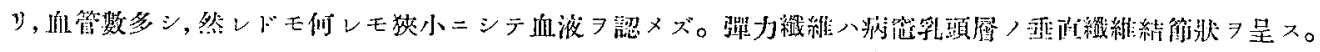

\section{（口）第 蕒 群}

\section{1. 第一型}

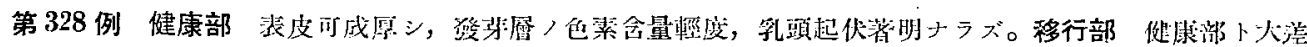

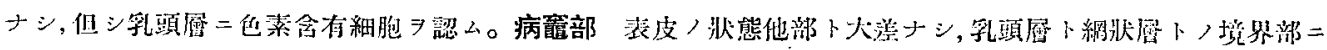

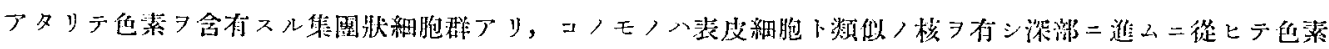

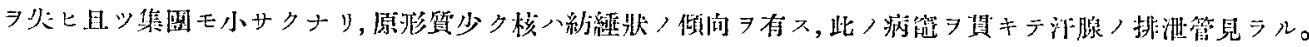

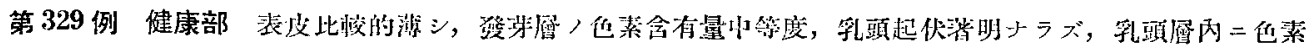

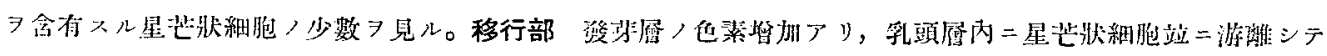

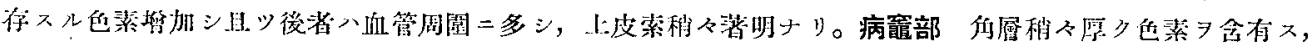

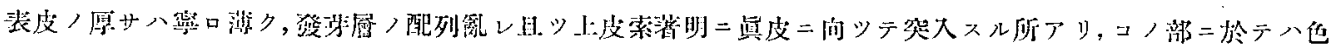

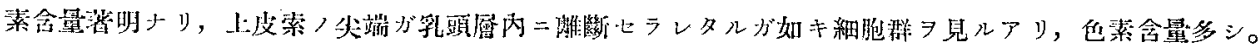

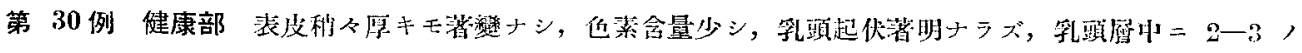

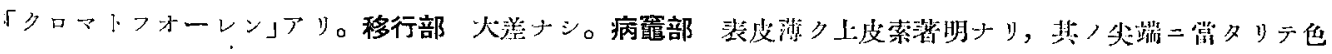

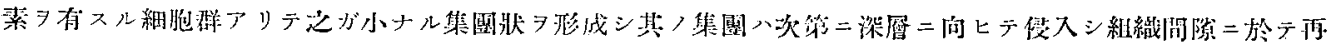

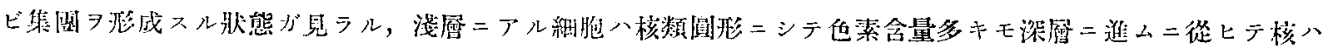

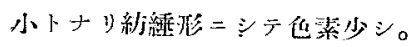

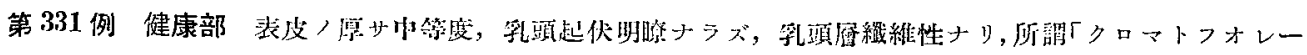

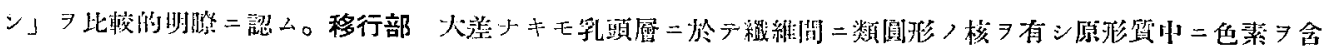

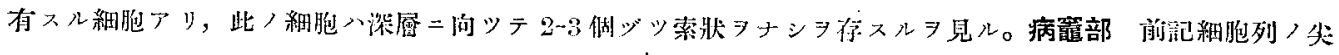

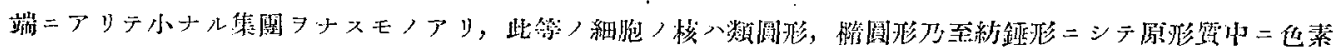
э含有不。

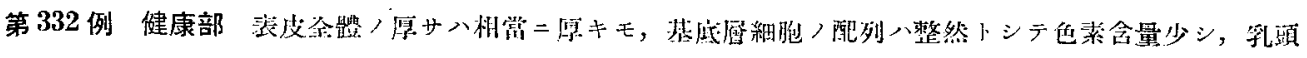

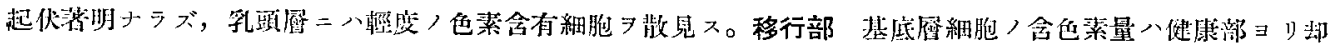

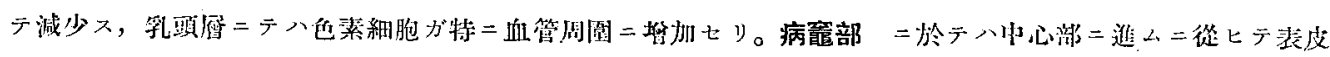

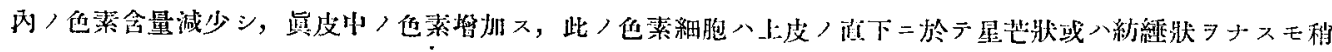

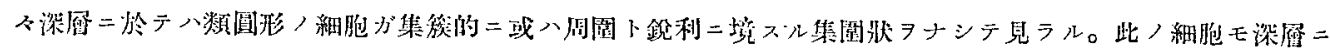

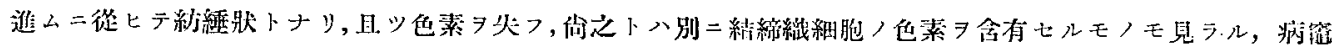
内 部二於テ少シ。 


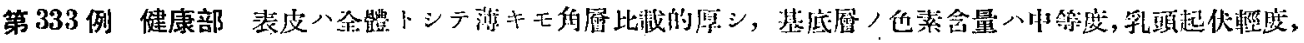

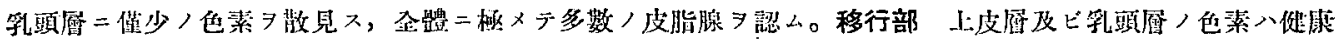

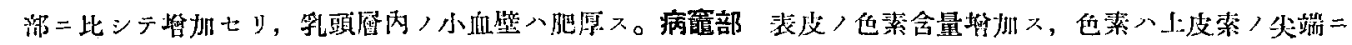

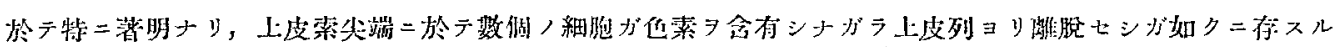

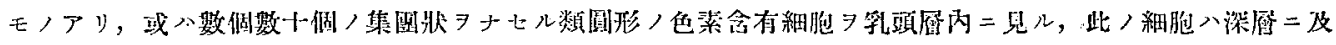

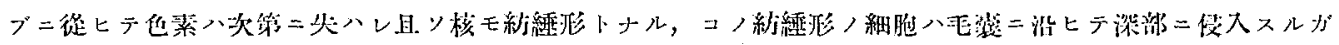

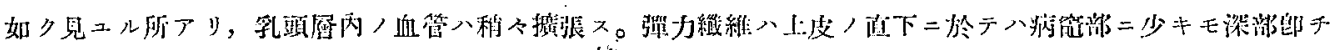

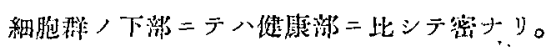

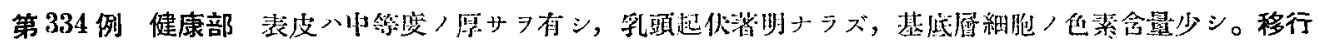

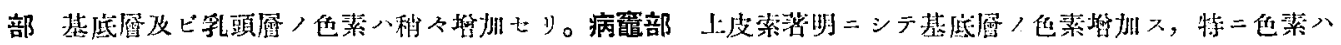

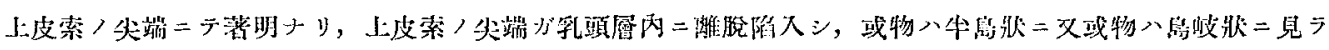

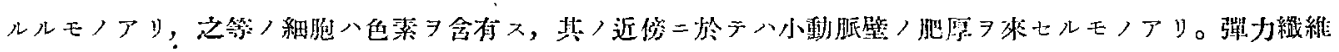
八健庵暗卜㵔戀小シ。

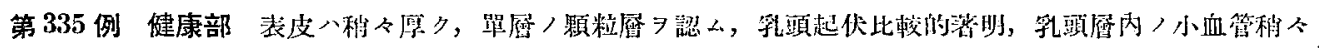

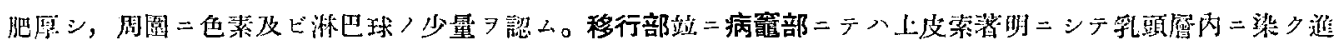

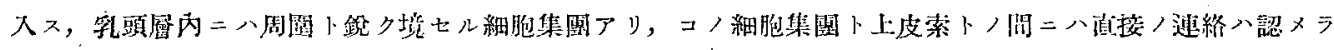

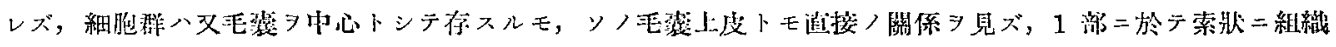

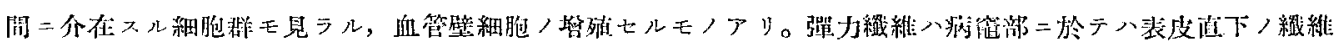

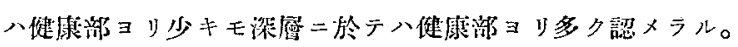

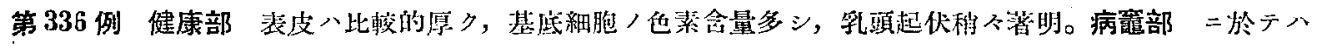

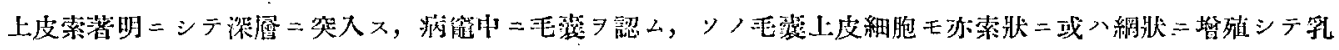

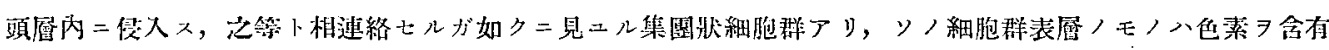

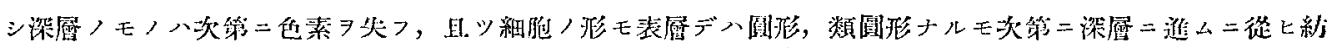
緟形トナリソノ配列八菜狀トナル。

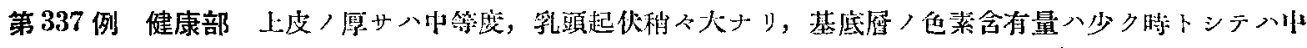

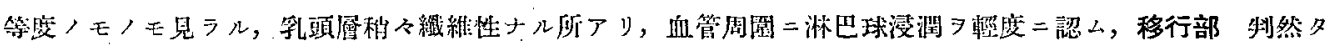

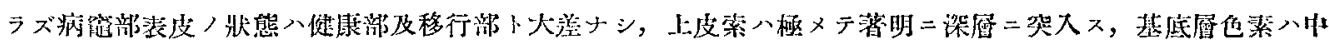

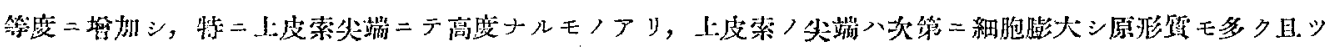

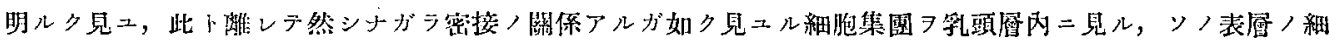

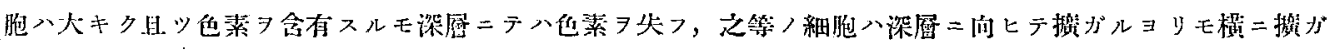

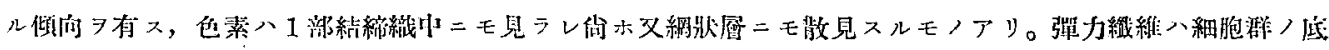
消二於テ密二証メラル。

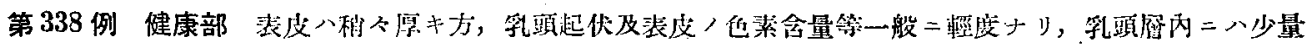

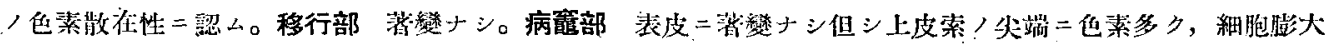

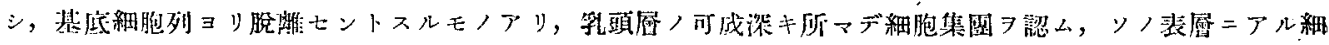




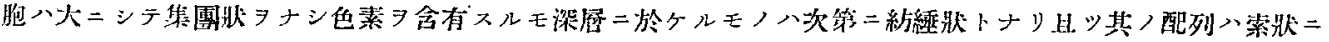

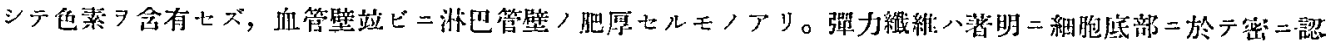
メシル。

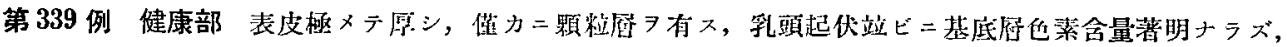

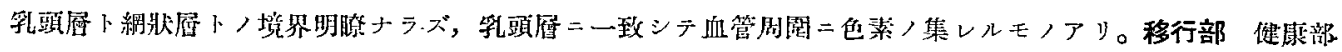

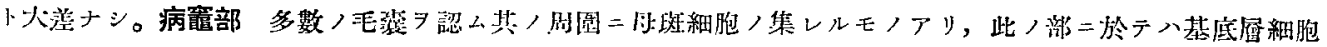

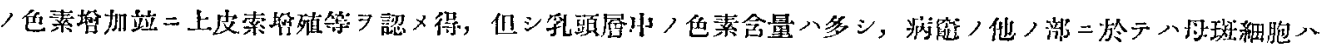

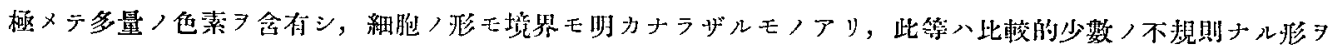

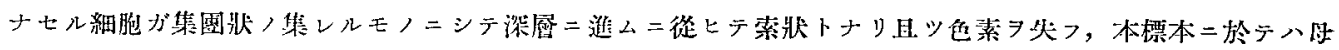

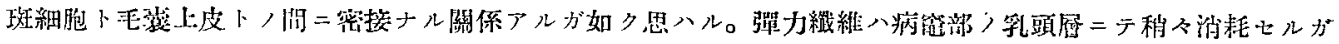
如シ。

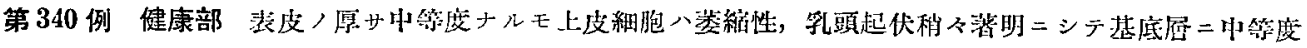

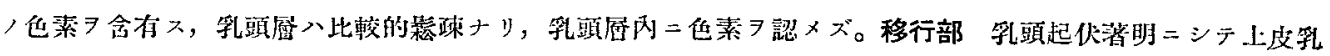

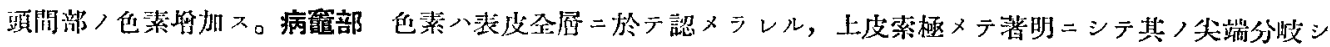

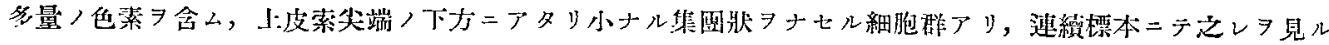

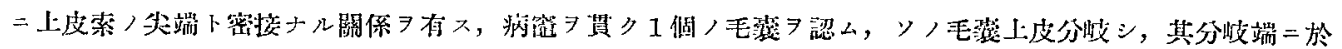

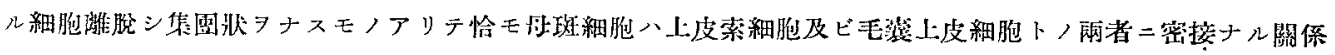

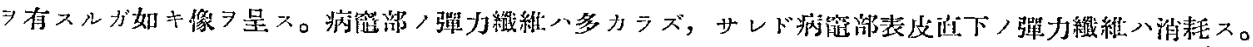

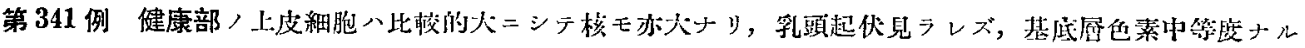

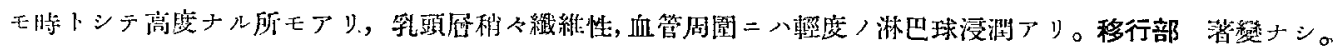

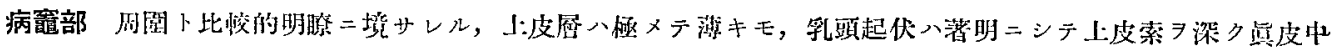

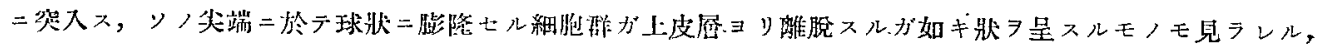

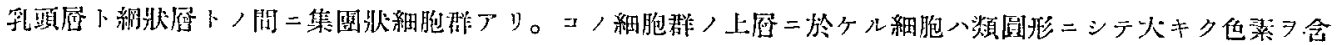

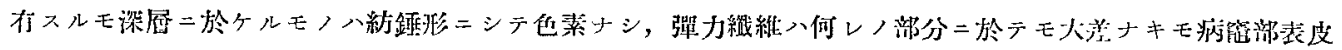
下,絽維八私ふ太シ。

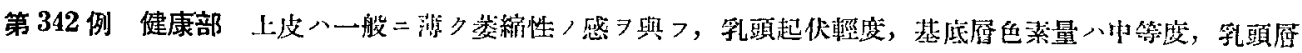

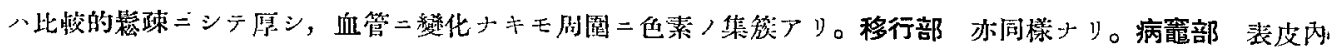

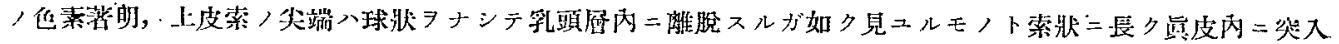

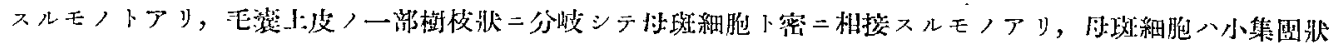
シナシテ多數アリ。

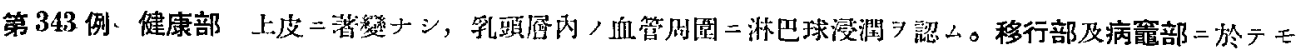

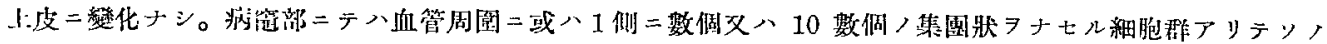

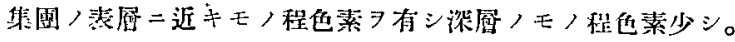

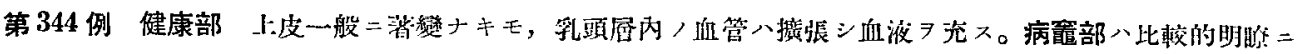

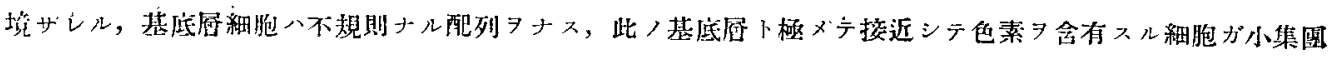




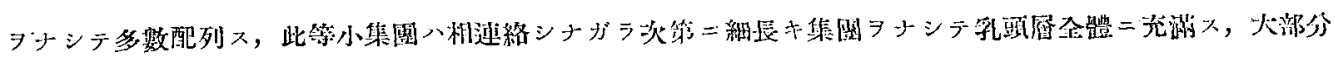

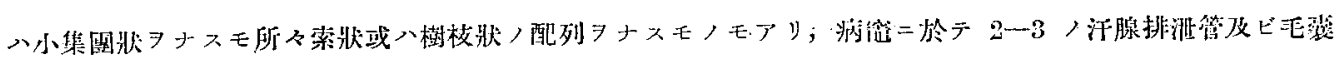

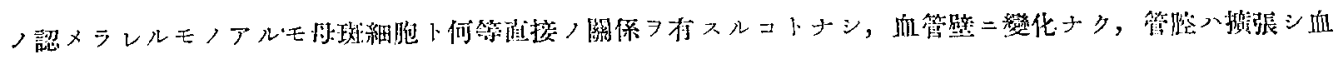

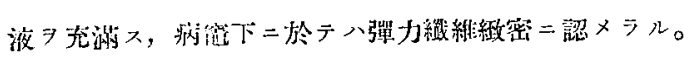

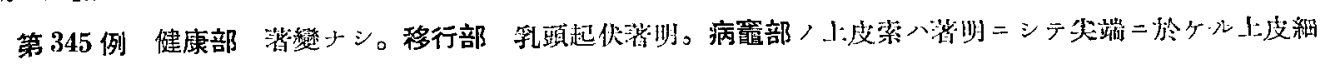

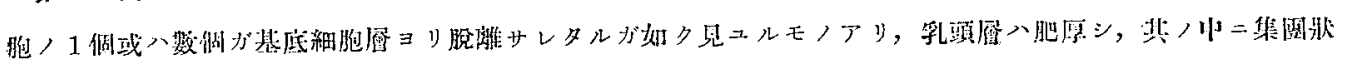

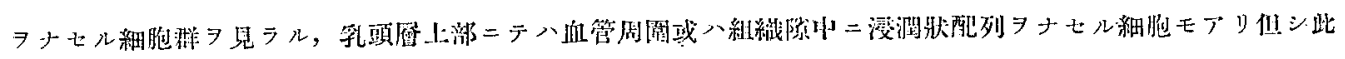

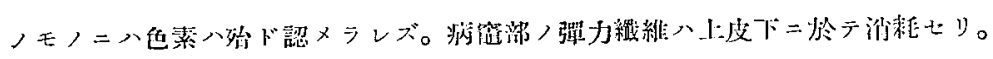

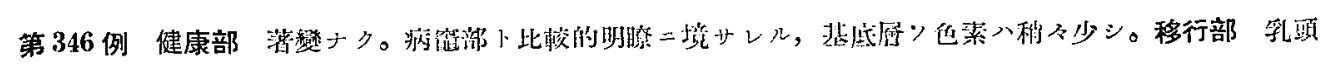

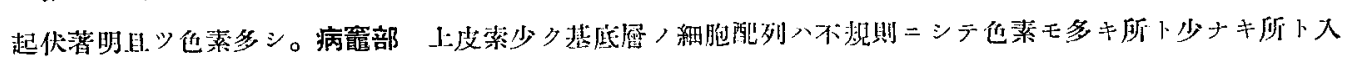

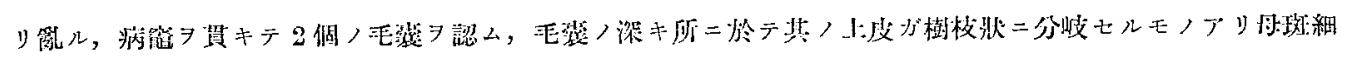

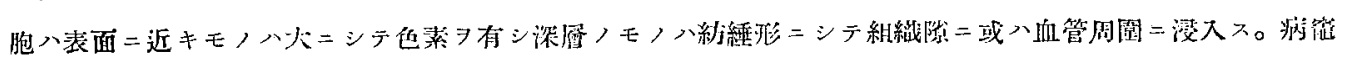

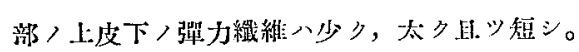

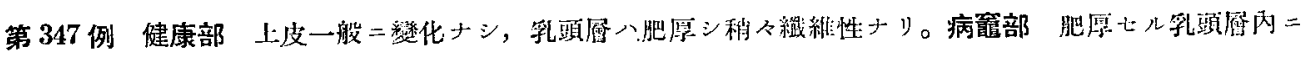

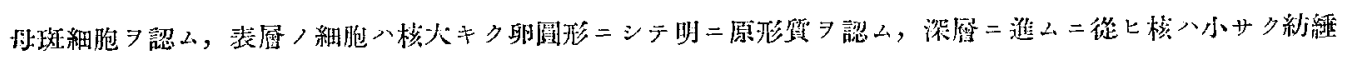

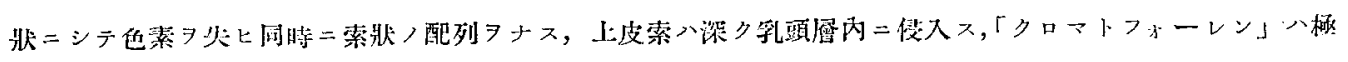
メテ少数

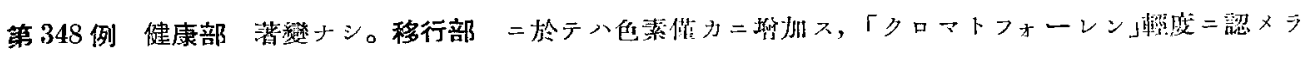

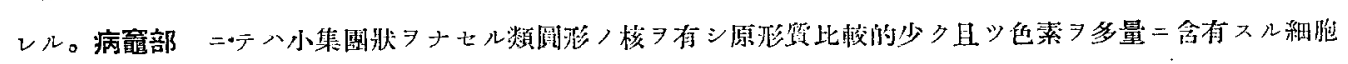

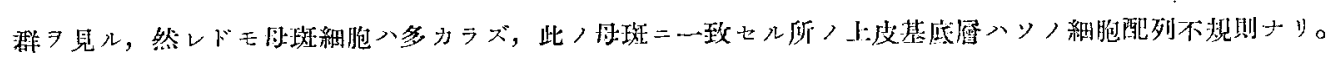

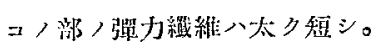

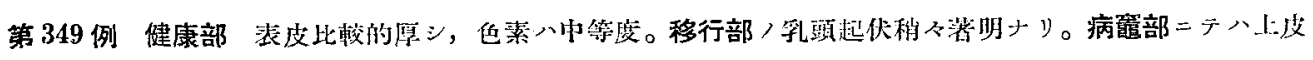
素/尖端球狀二膨大シテ其，或物八基底細胞居下明ナル境界

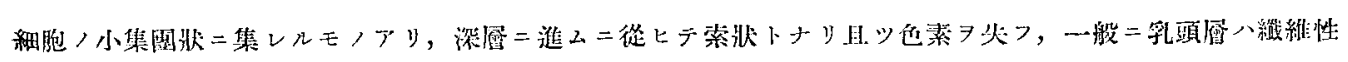
シシテ少量ノ「クロートフォーレン」ヨ有ス。

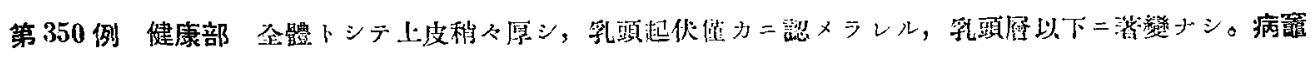

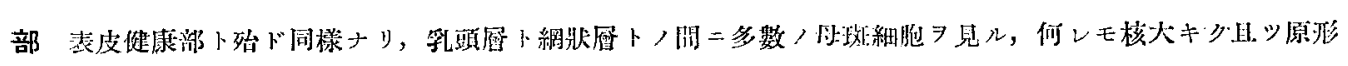

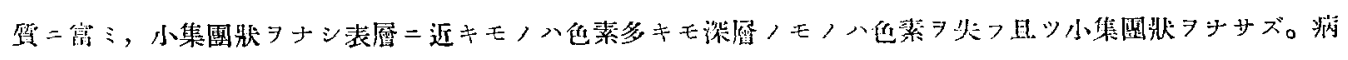
符部上亡皮下, 彈力綎維入消耗 7 見ル。

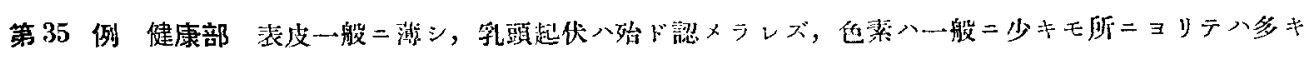

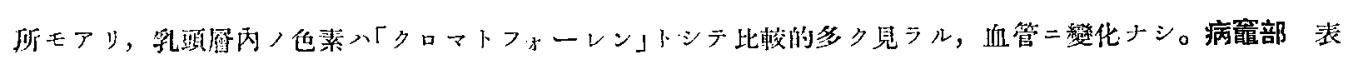

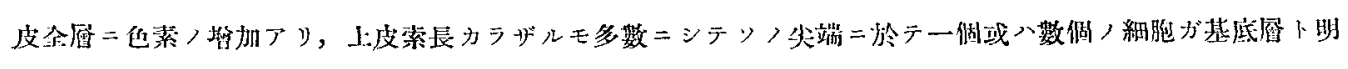

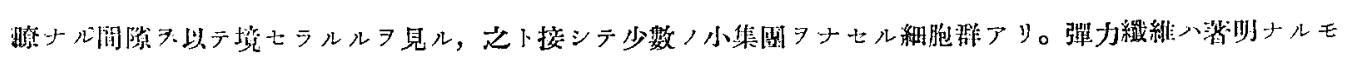
變化ナシ。

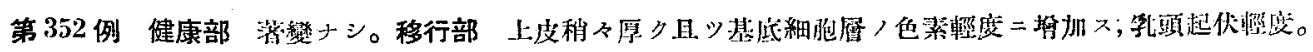
$-1028-$ 


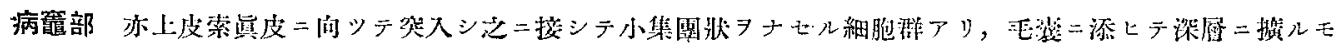

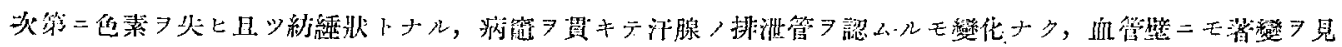

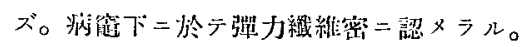

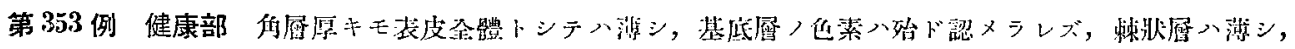

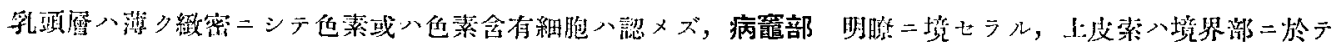

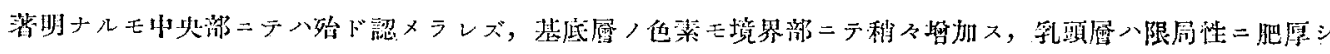

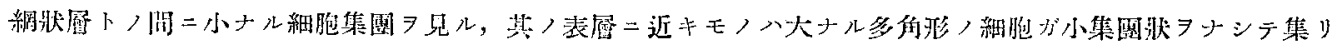

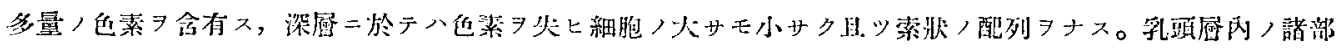

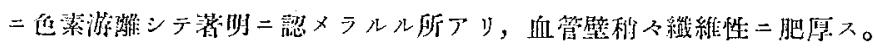

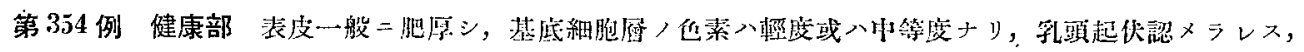

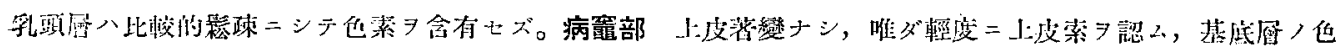

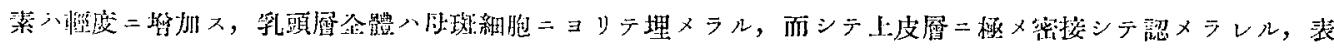

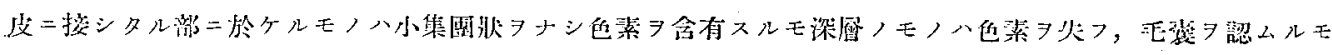

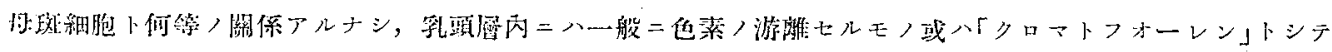

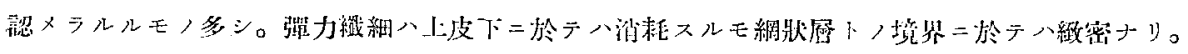

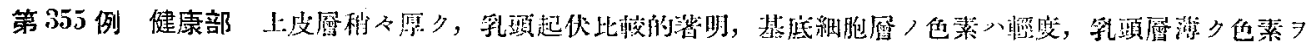

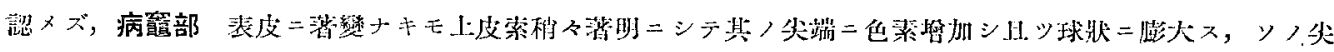

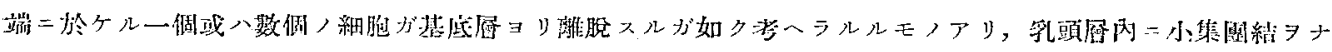

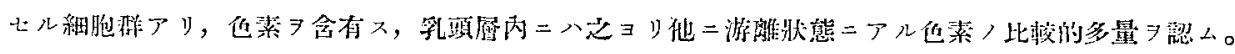

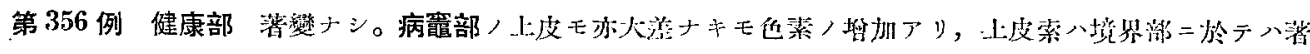

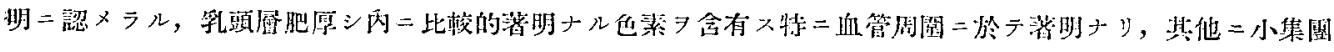

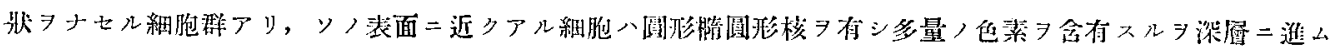

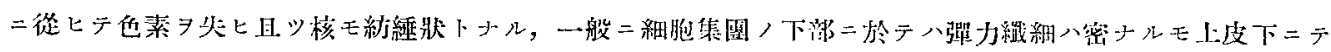

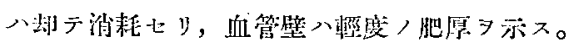

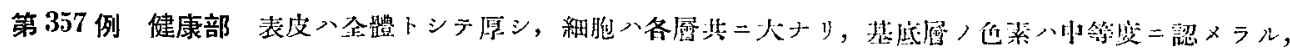

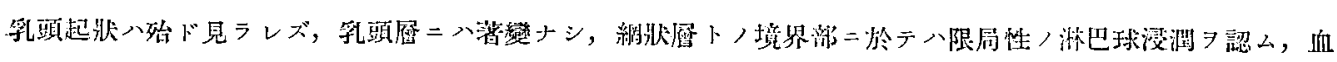

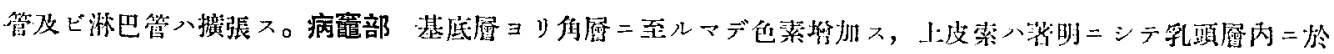

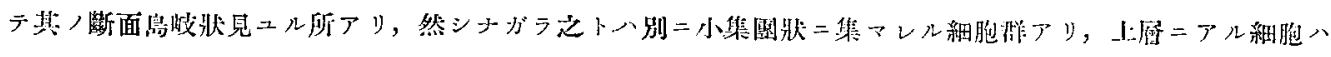

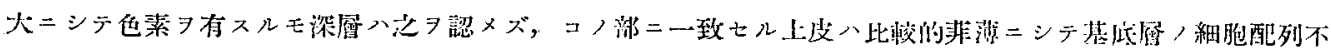

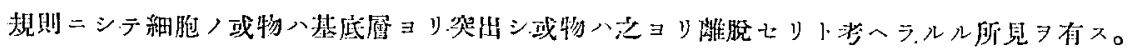

\section{2. 第 二 型}

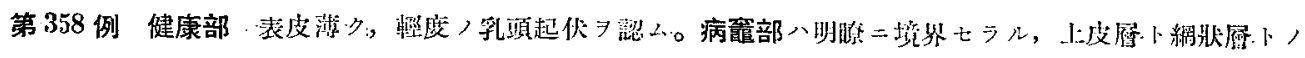

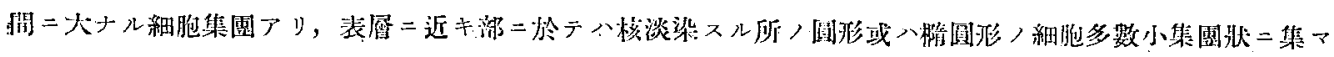

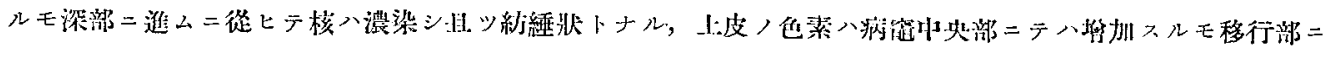

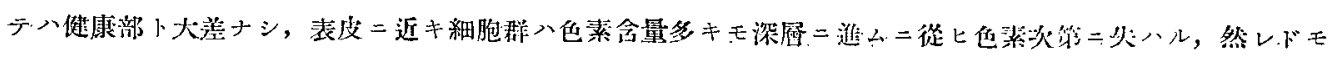




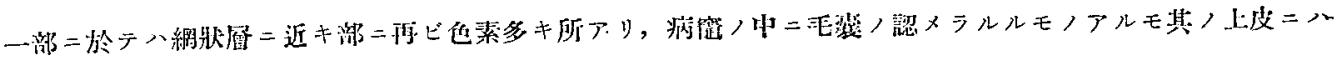

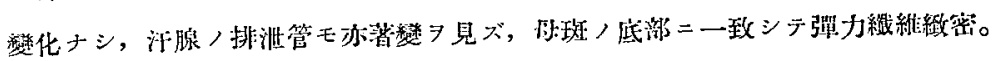

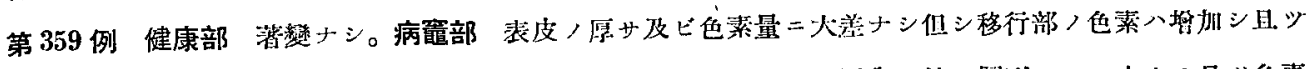

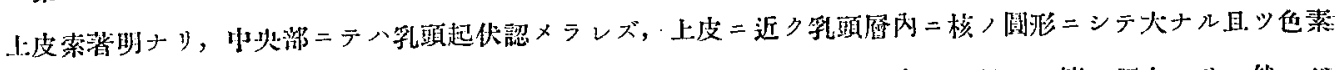

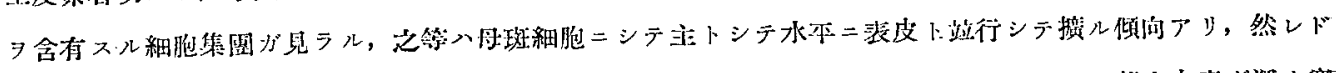

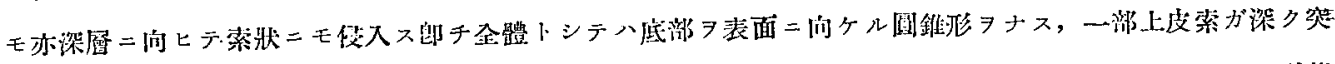

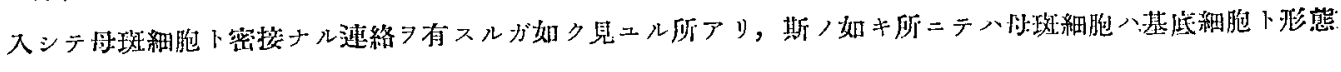

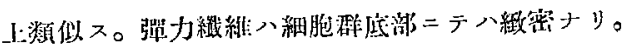

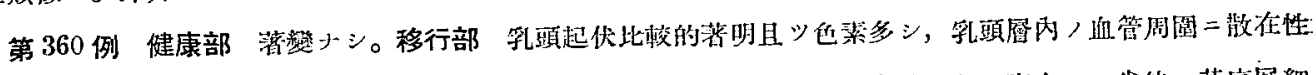

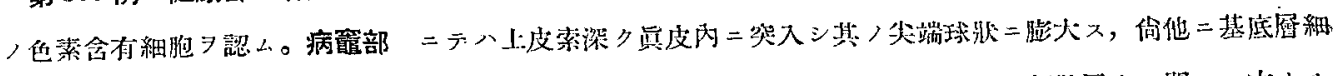

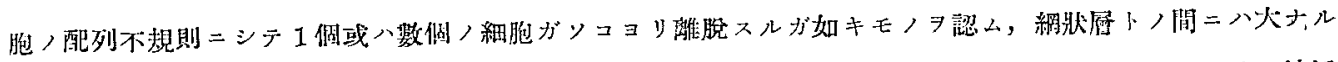

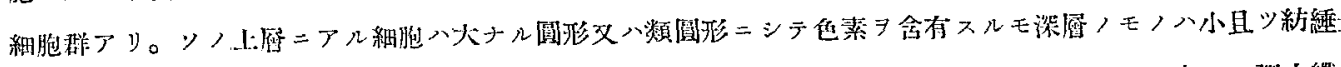

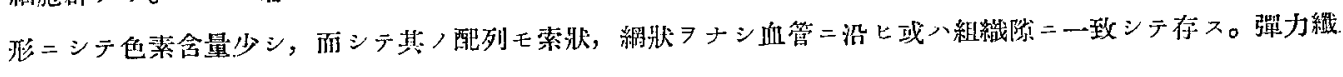
維八病窥表表下

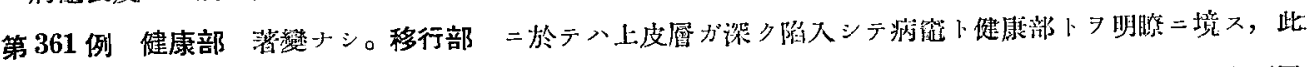

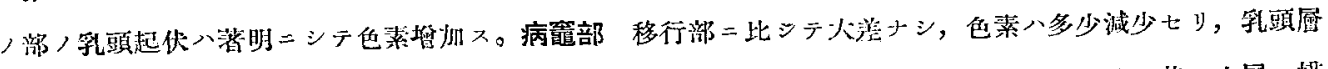

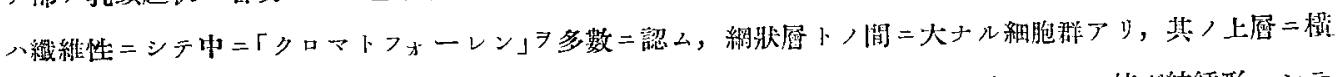

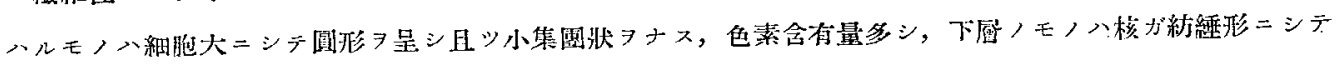

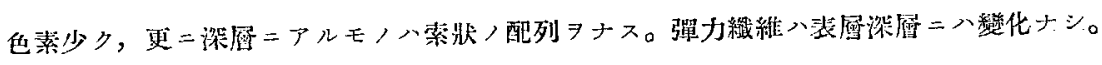

第 362 例 健康部上皮中等度，愿サ

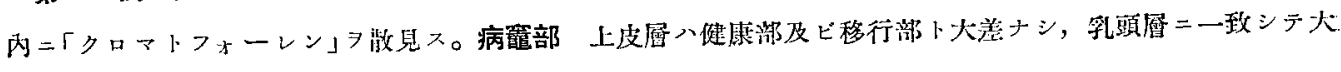
ナル船胞篹圈アリ其，所見八第 361 例下殆ド同榜ナリ。

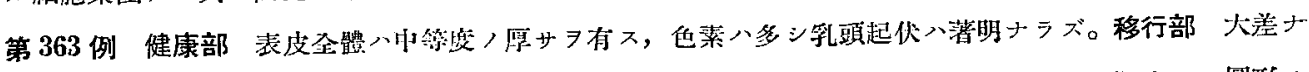

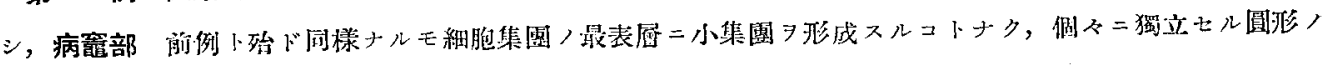
大ナ儿色素含打細胞 7 見ル。

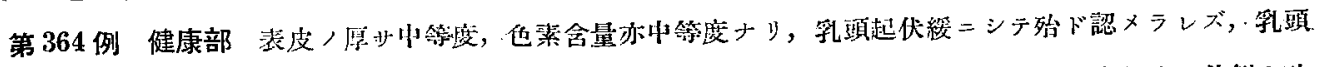

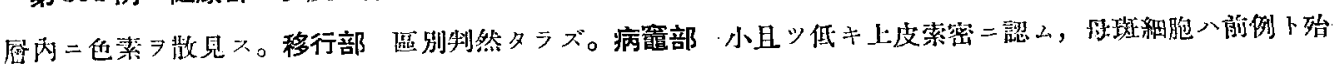

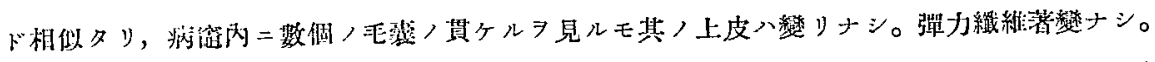

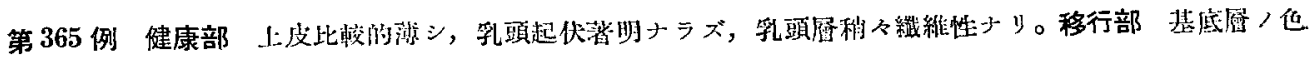

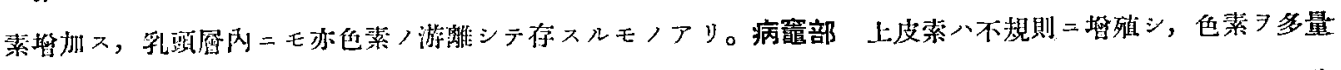

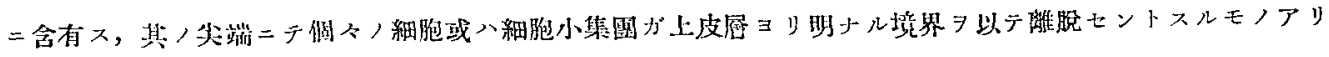

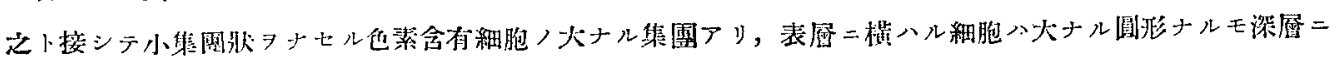

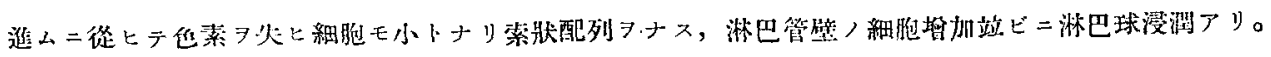

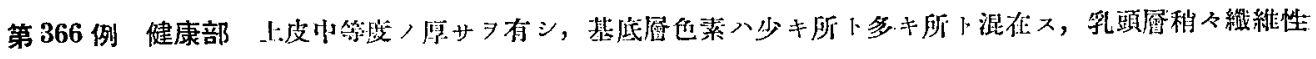

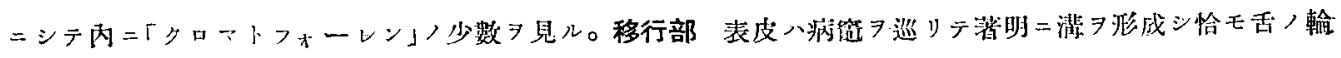




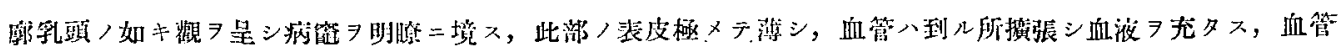

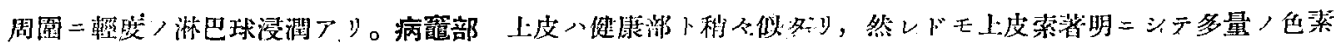

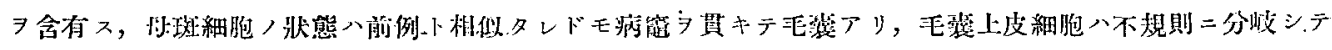

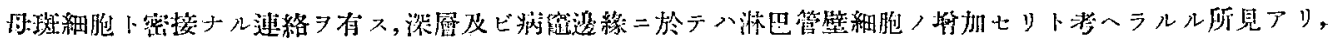

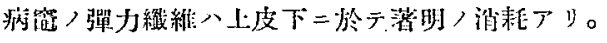

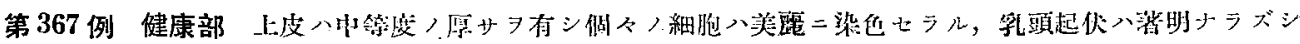

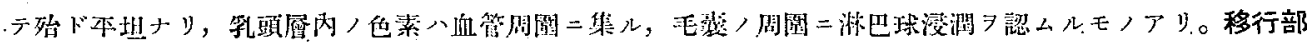

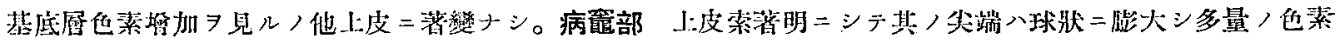

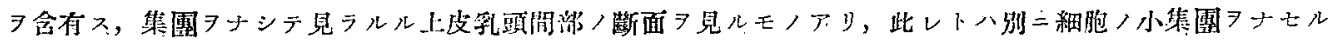

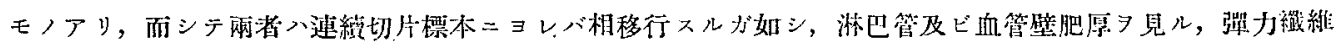

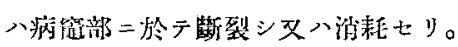

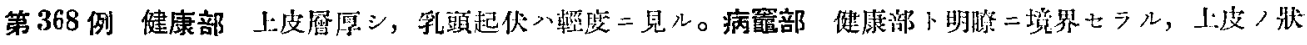

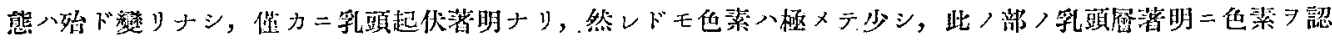

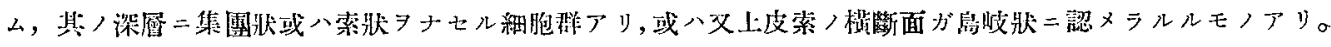

第 369 例 健康部 上皮尿八丩等度ノ厚サ

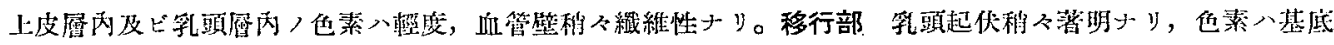

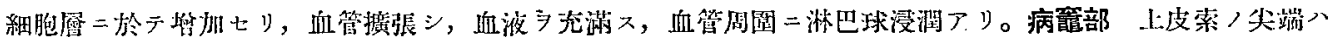

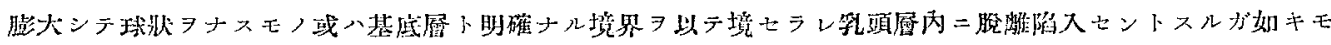

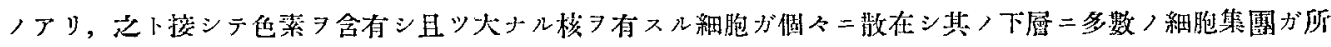

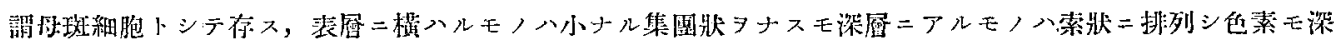

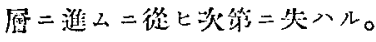

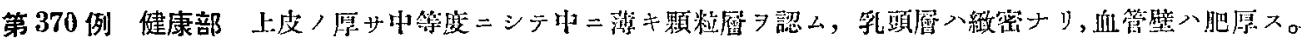

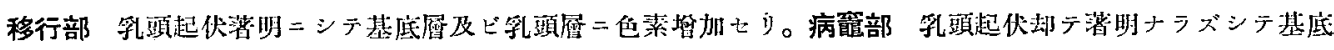

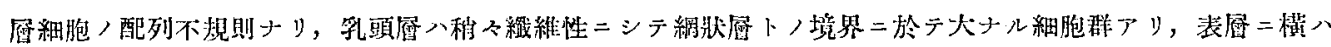

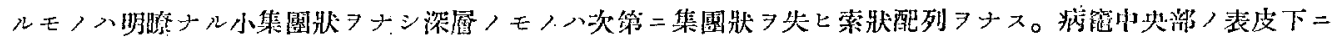

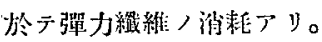

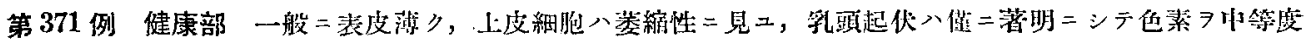

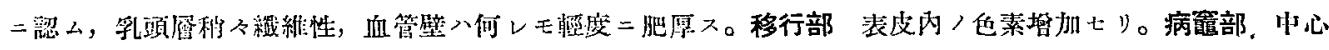

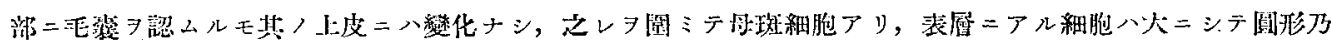

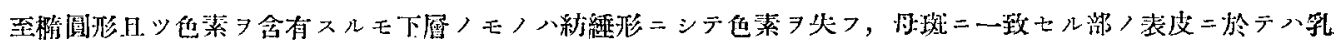

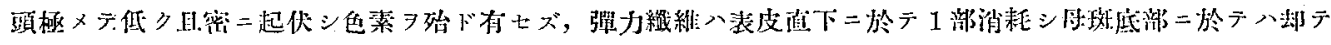
緻密ニシテ明カ二認メラル。

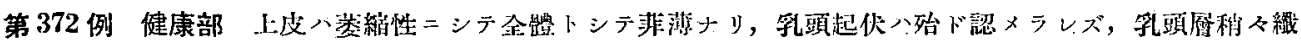

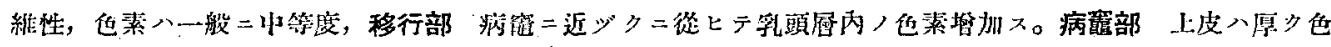

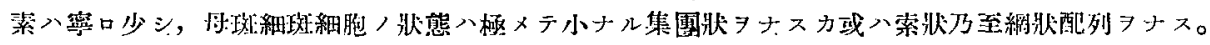




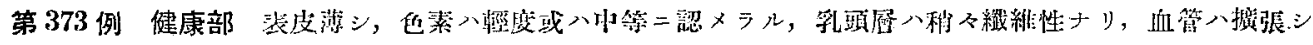

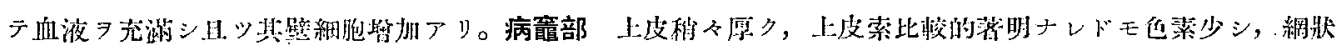

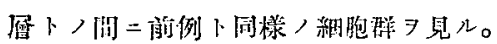

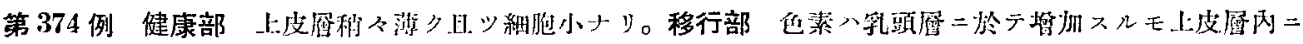

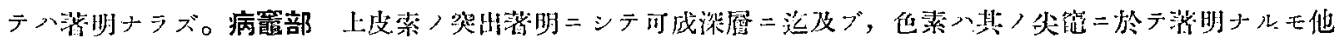

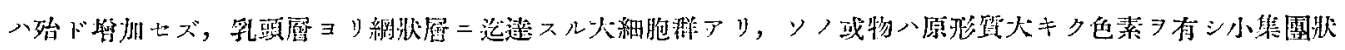

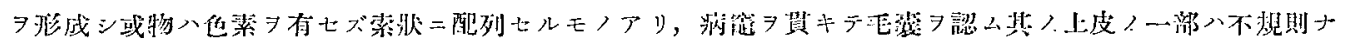

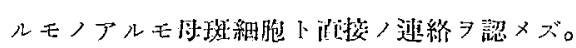

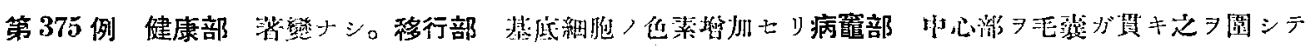

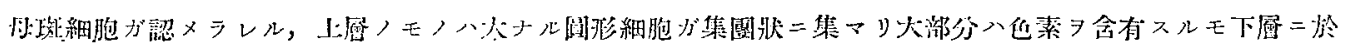

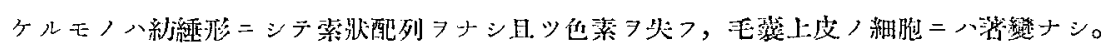

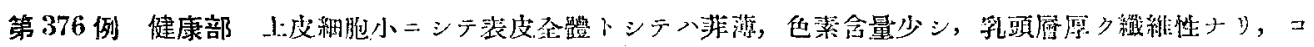

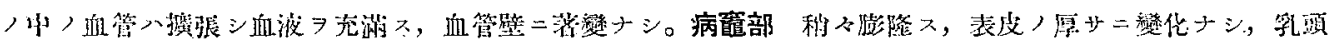

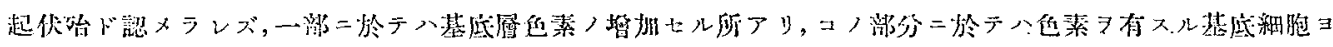

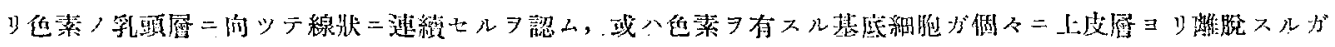

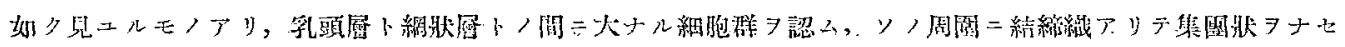

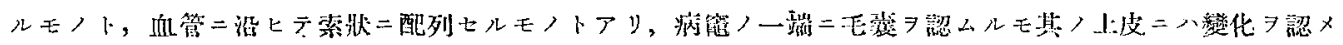

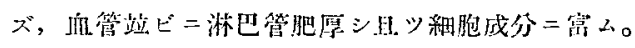

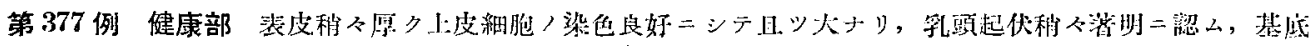

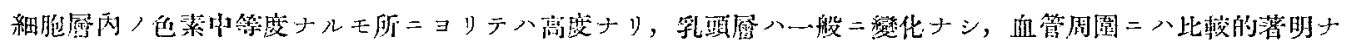

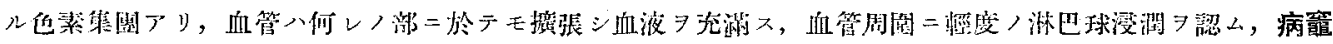

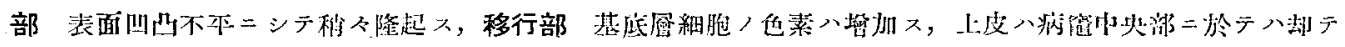

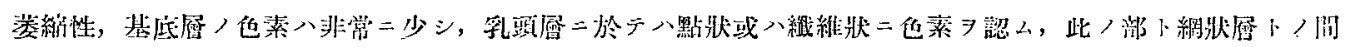

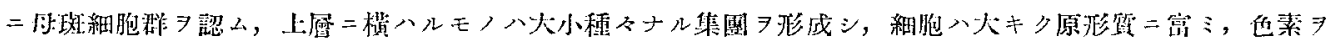

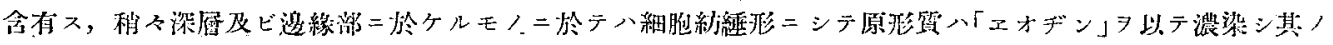

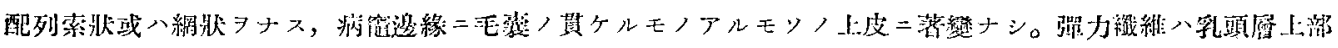
二於テ萎縮性ナルモ下屡ニテハ維密ナリ。

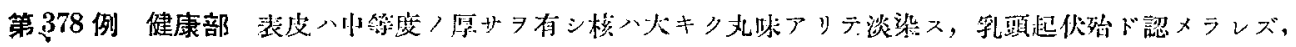

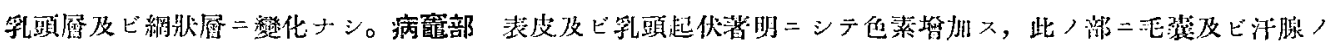

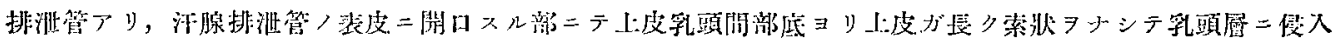

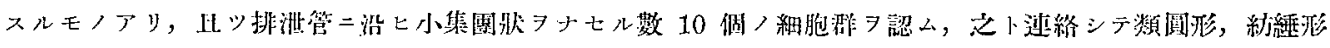

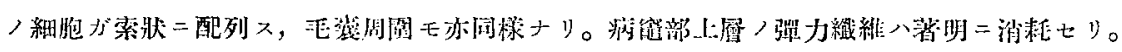

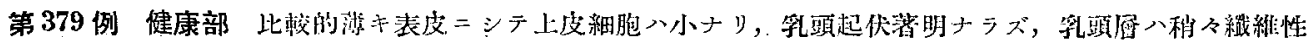

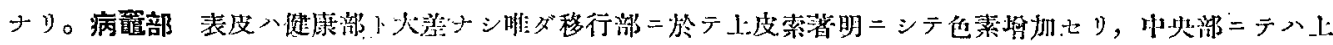

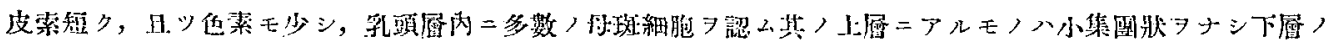




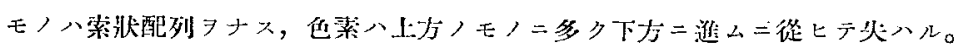

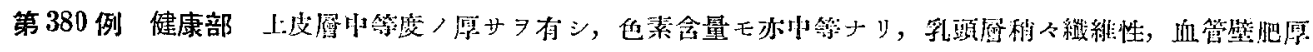

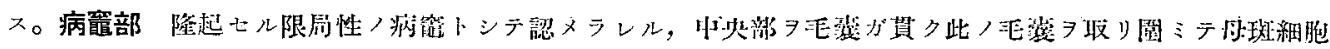

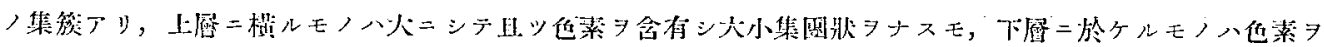

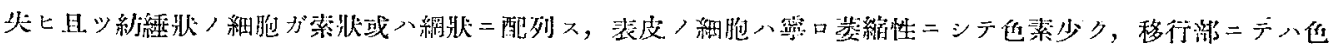
素量多シ。

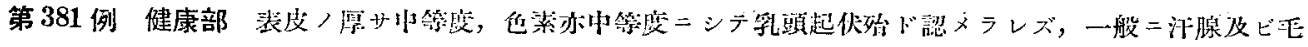

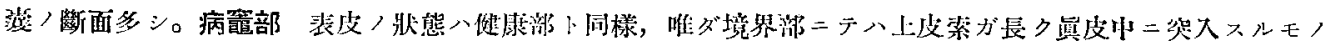

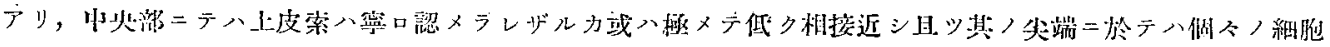

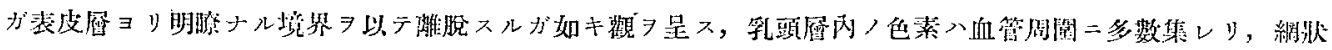

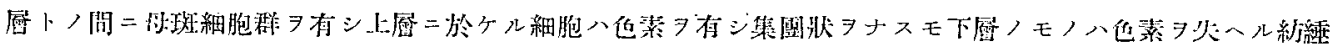

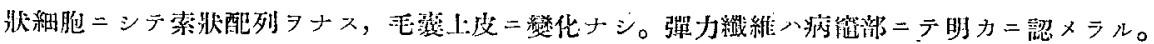

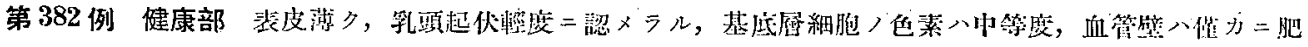

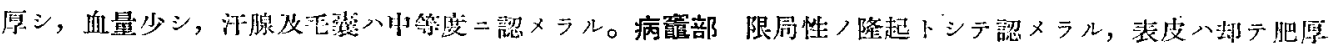

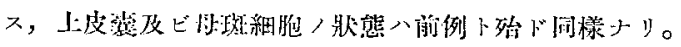

\section{3. 第三型}

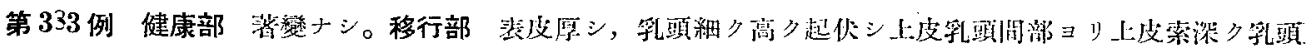

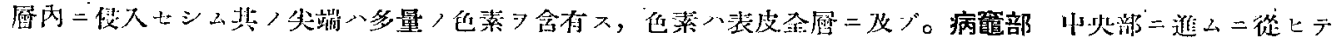

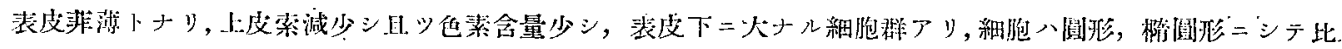

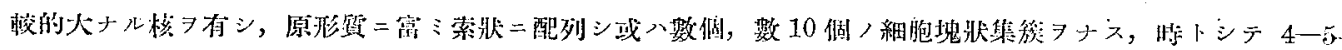

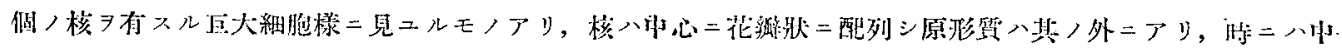

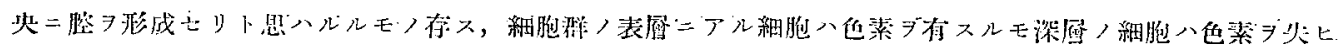

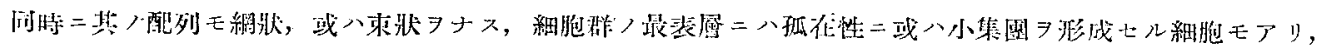

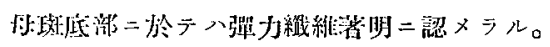

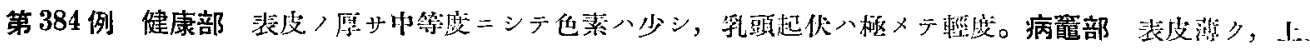

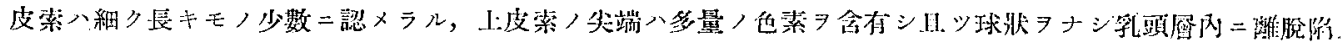

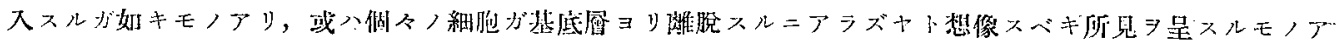

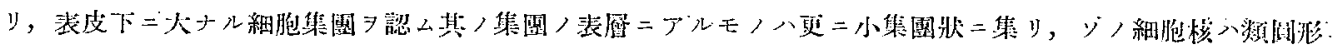

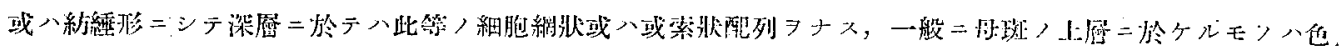

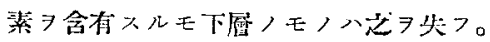

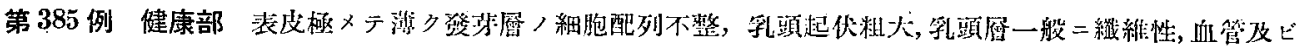

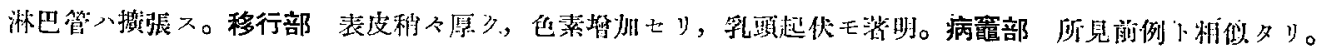

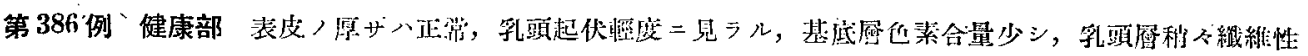

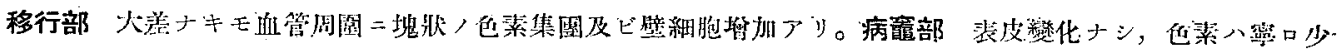

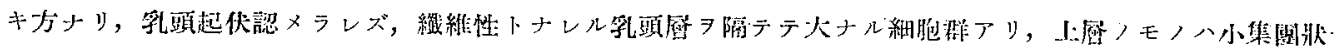




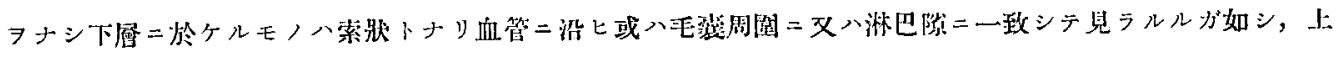

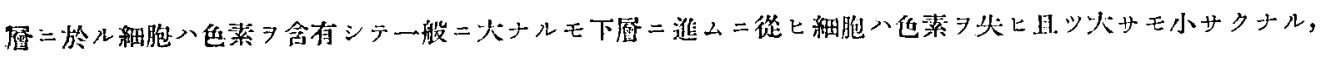

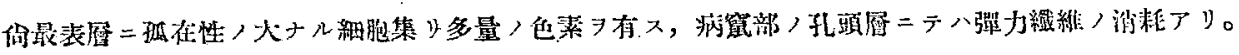

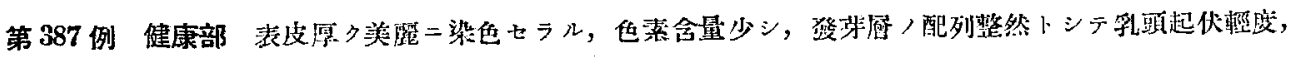

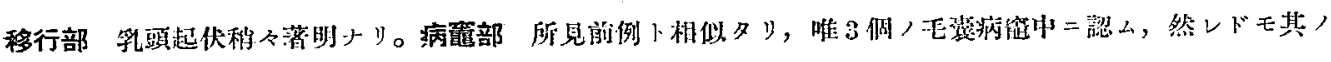
上:皮ニ八渚誉ナシ。

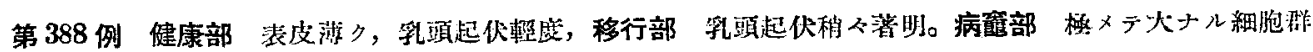

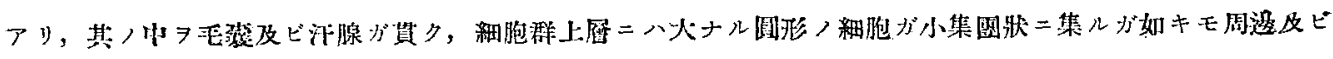

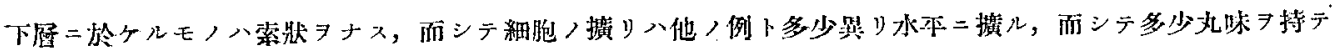

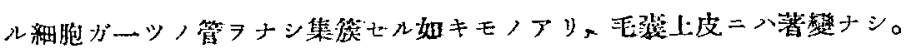

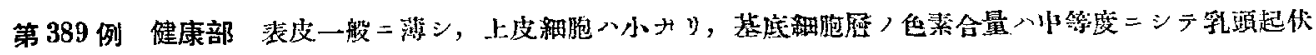

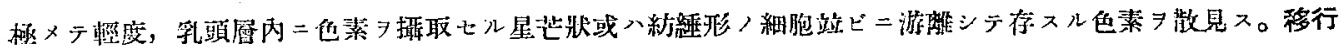

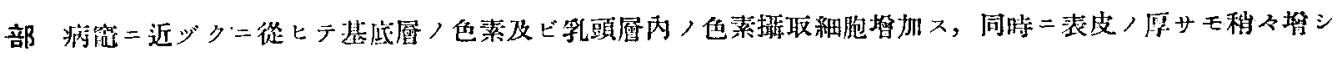

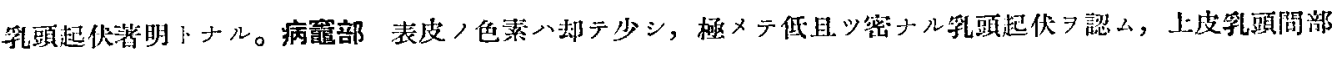

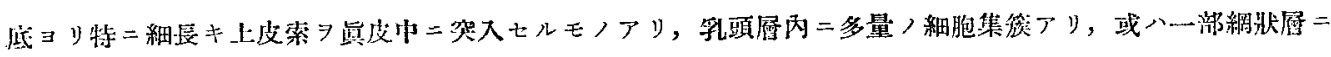

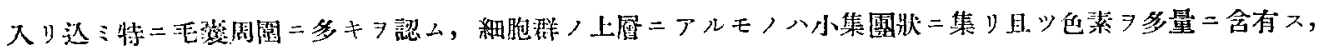

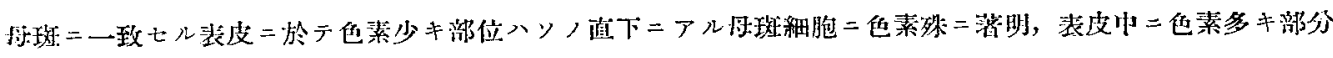

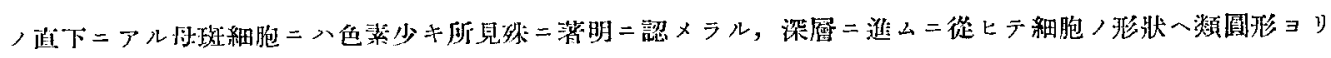

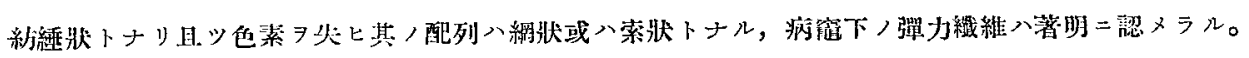

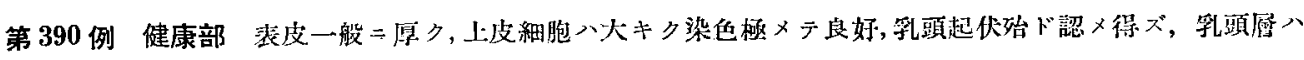

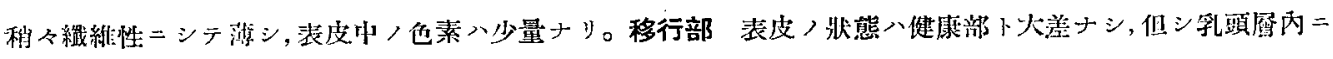

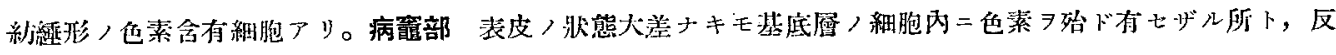

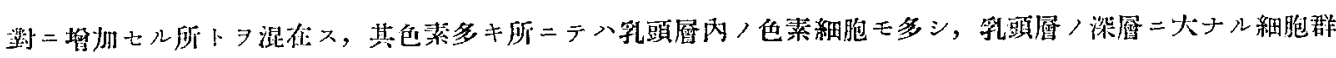

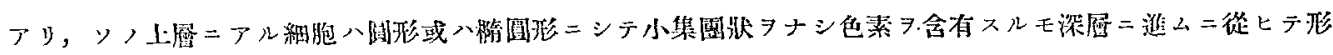

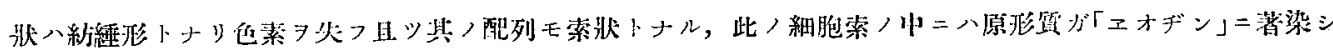

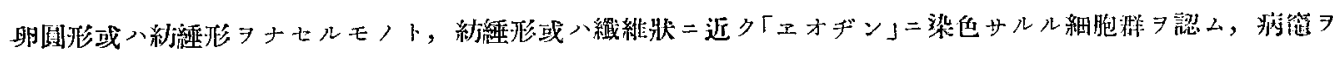

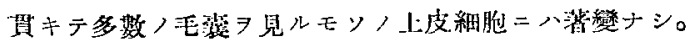

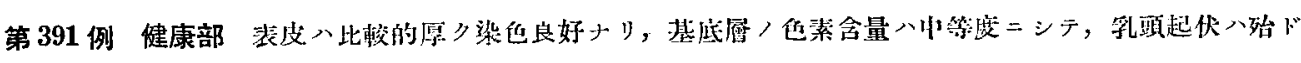

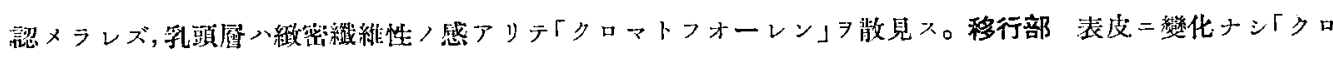

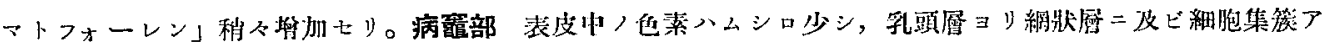

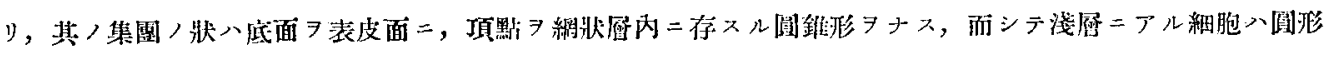

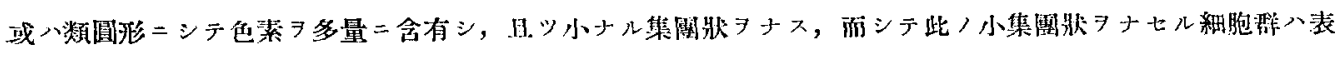

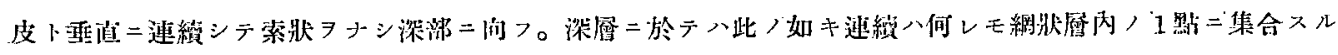

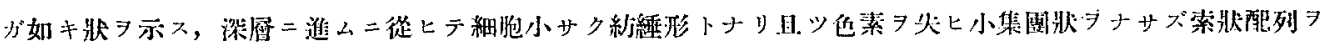

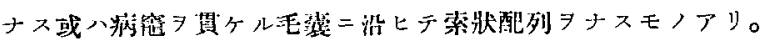




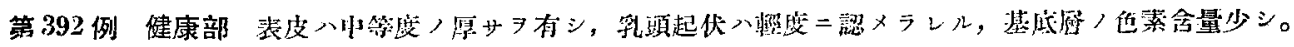

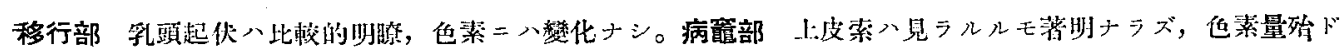

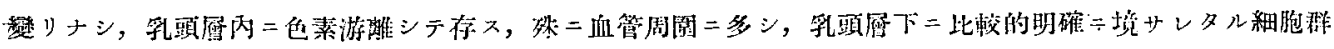

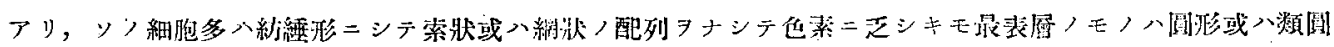

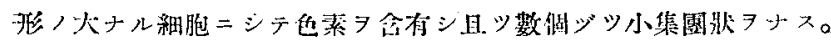

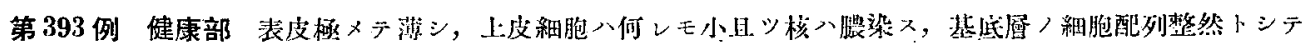

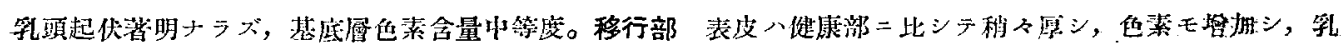

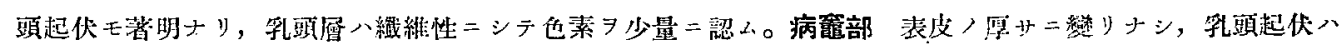

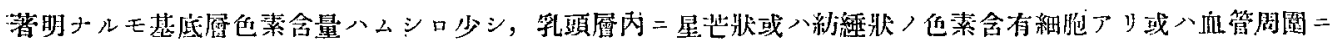

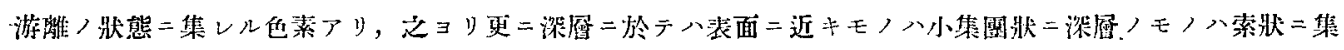

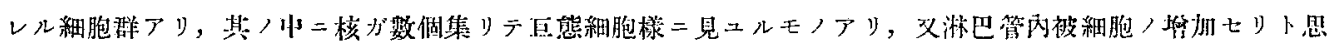

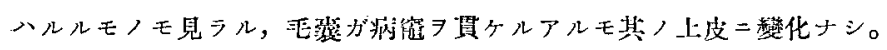

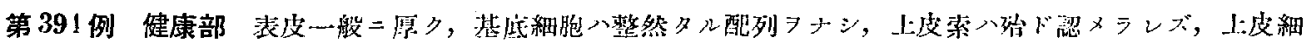

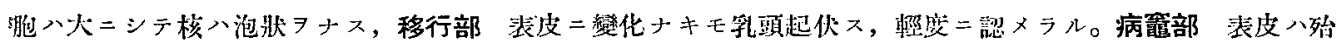

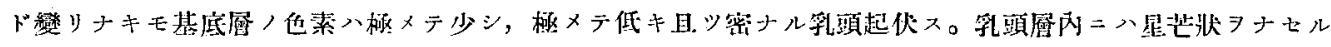

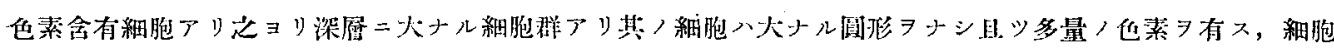

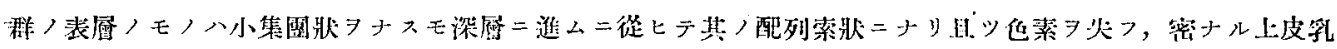

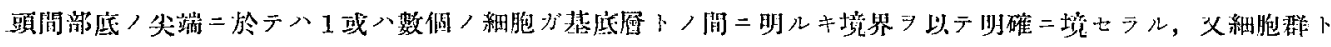

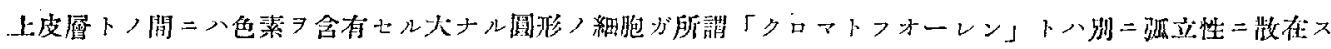

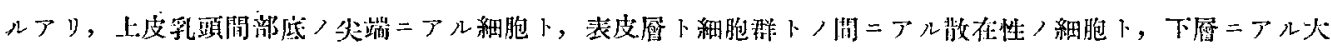

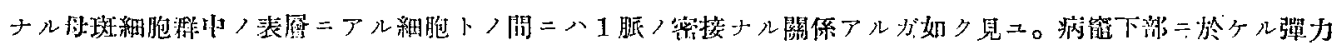
程秛八維密とリ。

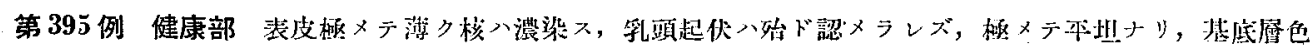

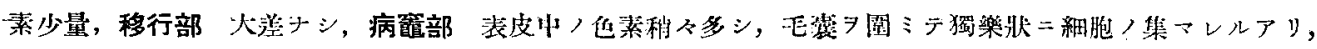

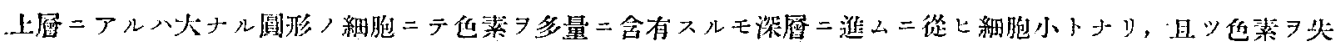

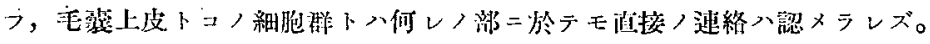

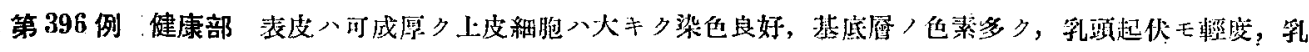

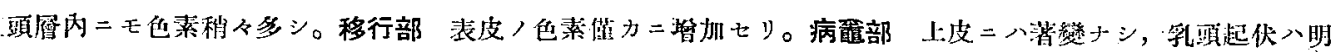

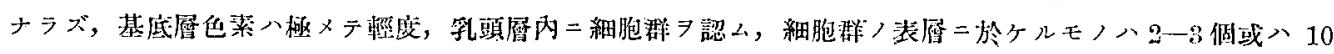

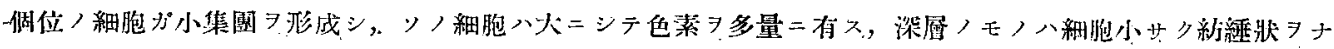

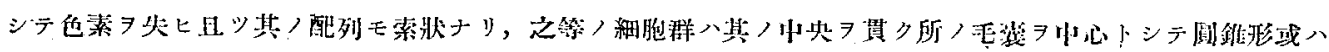

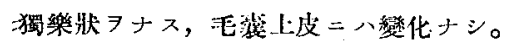

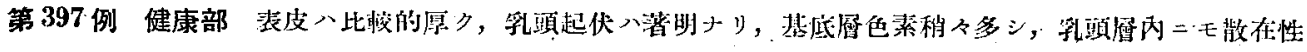

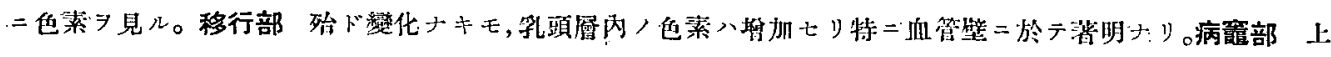

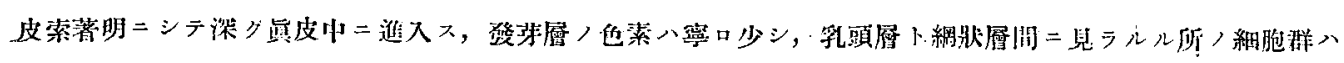


前例卜殆ド间㭼ナリ，

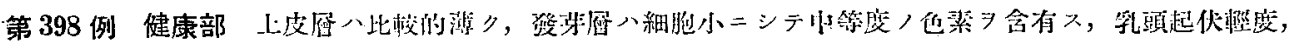

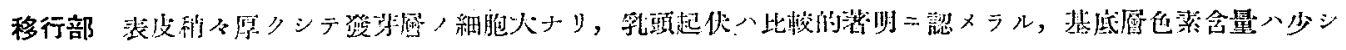

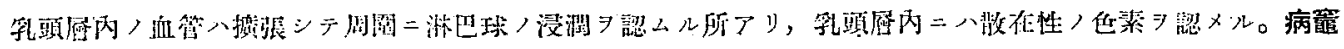

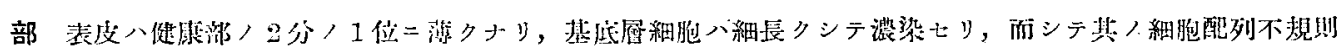

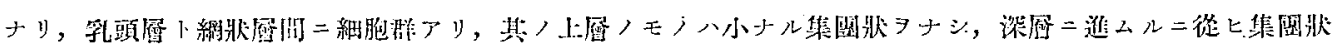

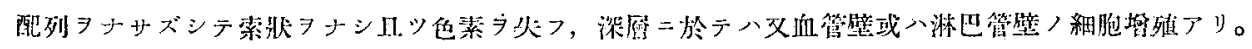

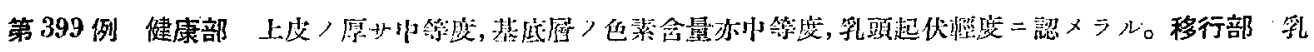

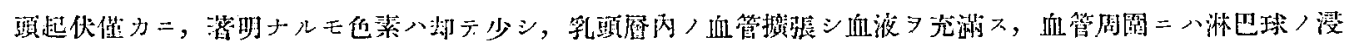

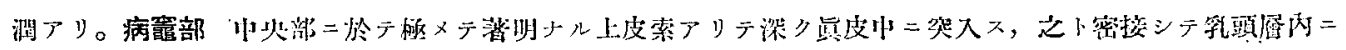

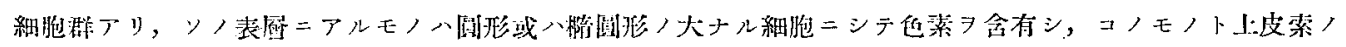

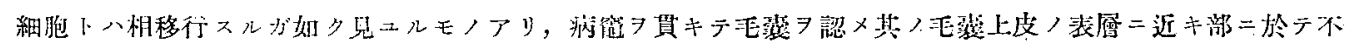

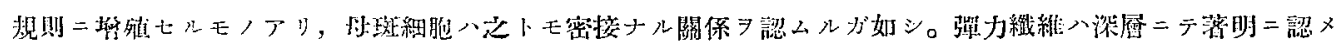
ラル。

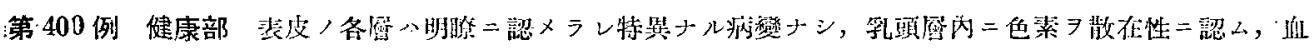

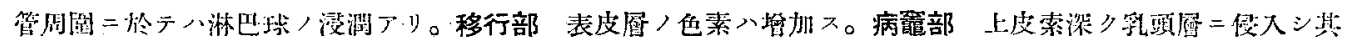

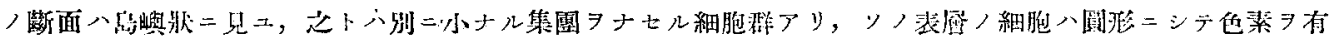

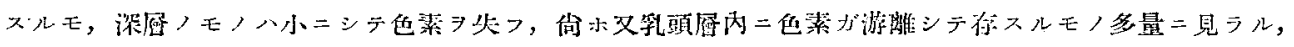

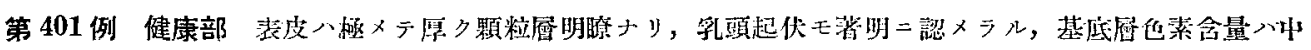

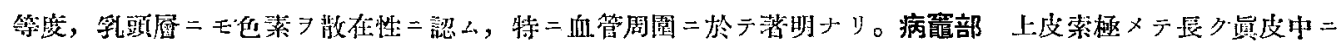

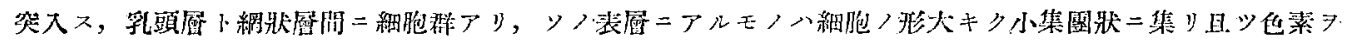

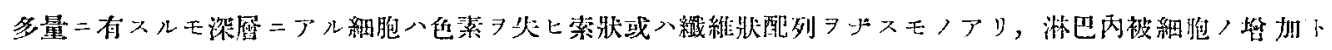

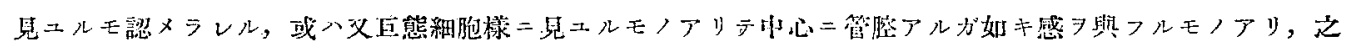

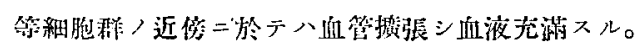

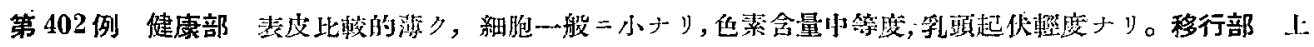

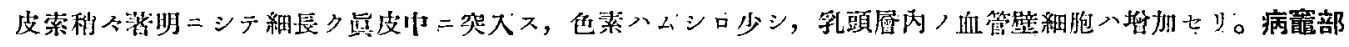

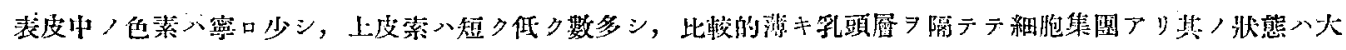
體獄例卜相似タリ。

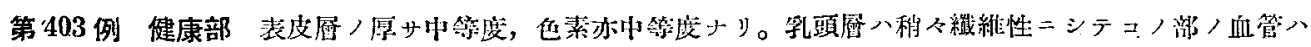

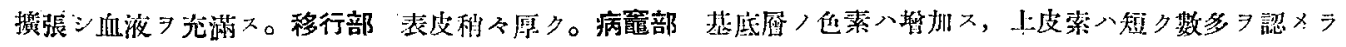

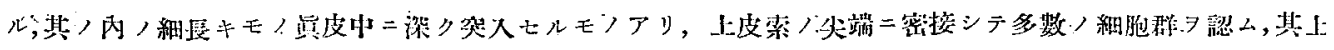

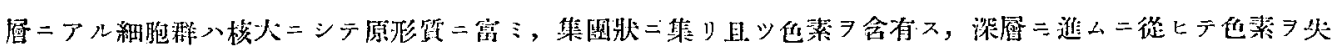

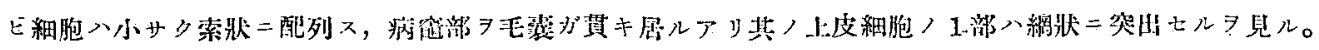

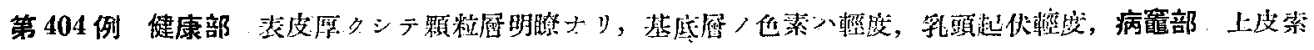

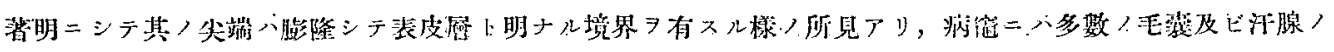




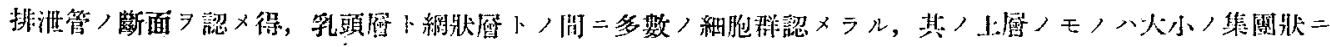

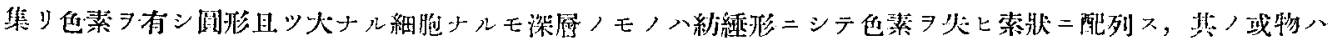
淋巴管队披細胞, 堆殖卜見ラルルモノアリ。

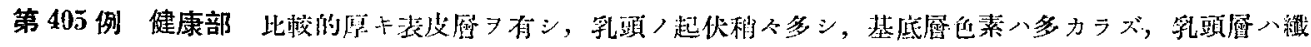

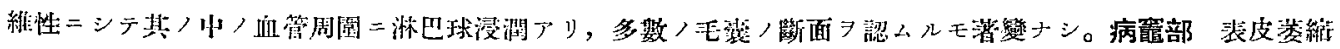

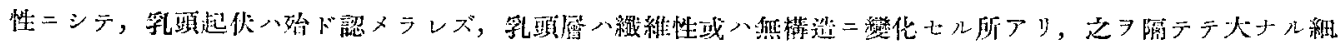

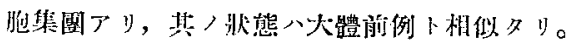

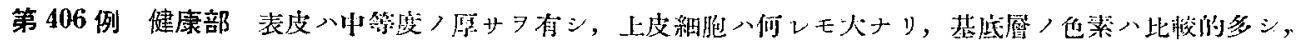

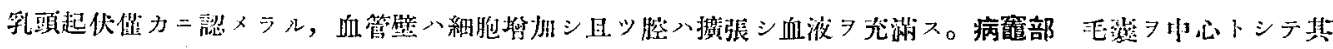

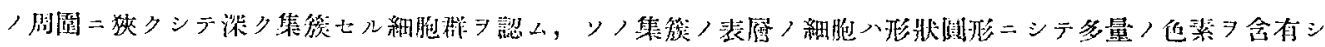

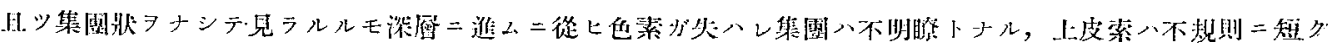

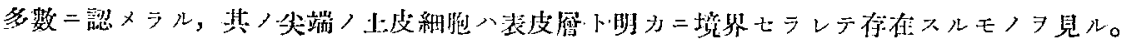

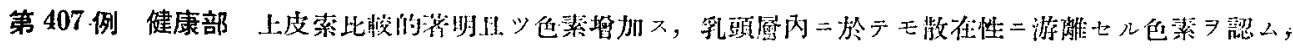

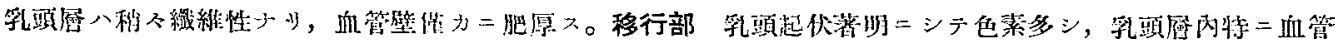

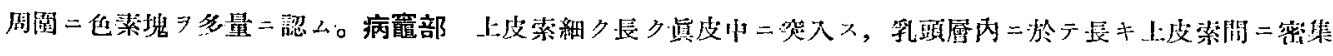

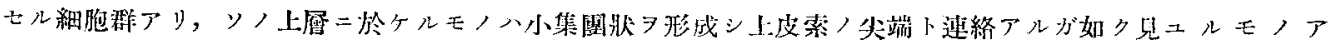
リ，狱筑部

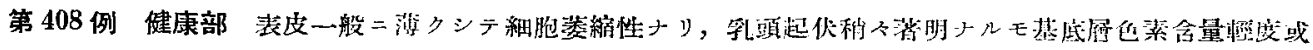

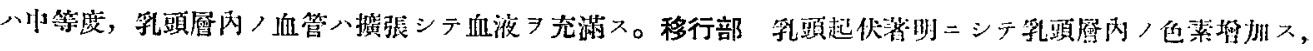

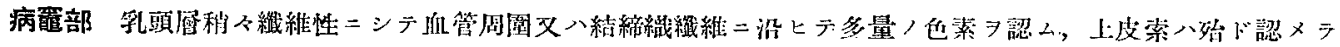
レズ，表皮一船二極メテ薄ク凡ツ殆ド企ク色素

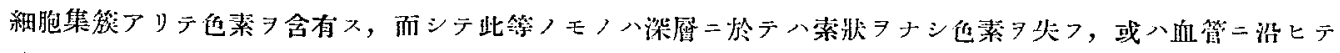

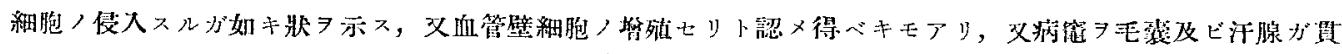
ク。

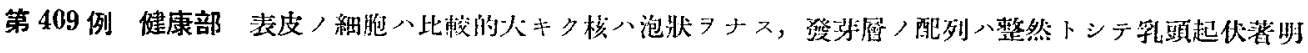

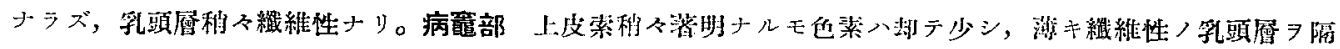

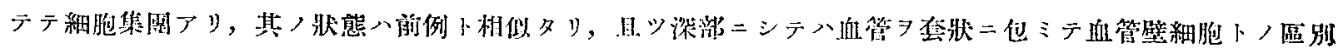
不时ナルモノアリ。

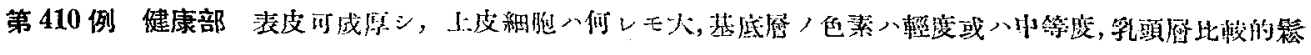

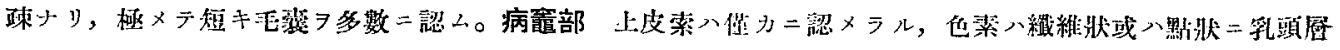

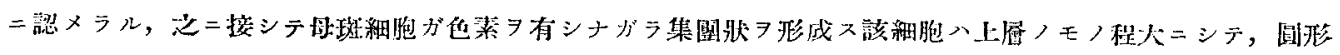

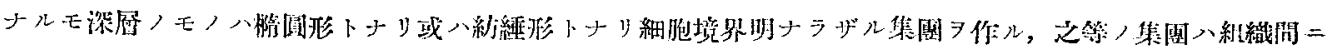

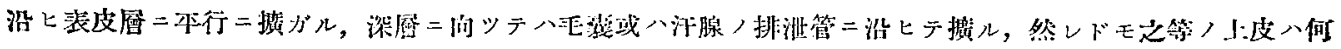

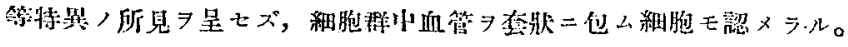

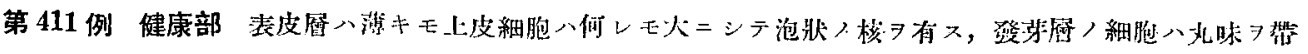




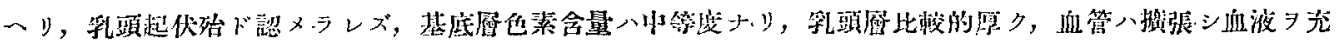

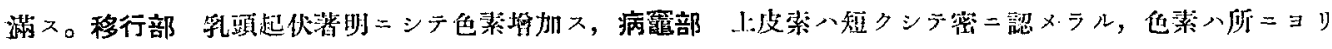

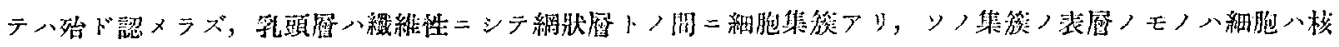

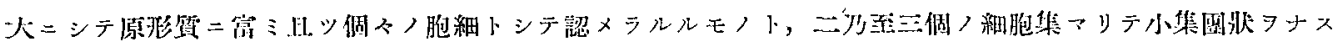

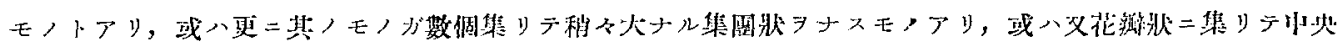

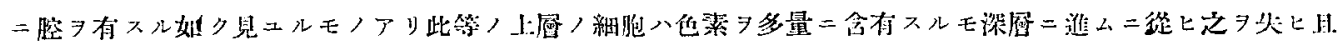

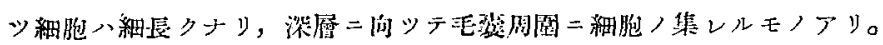

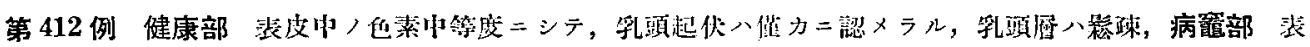

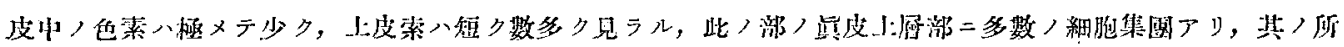
見八概市前側下相似夕リ。

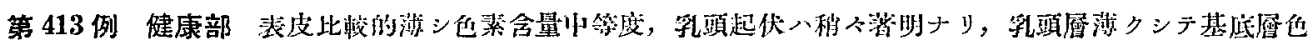

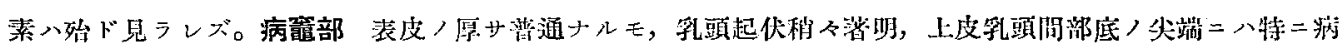

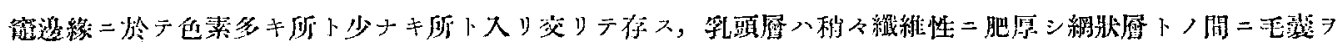

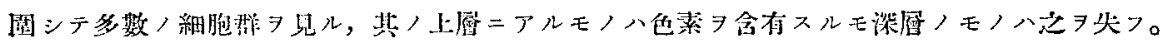

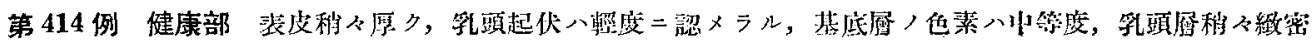

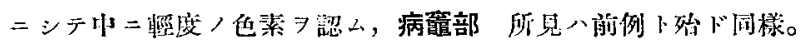

\section{4. 第 四 型}

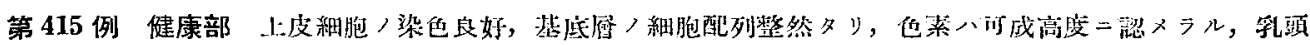

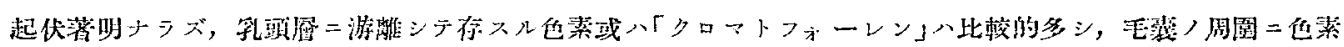

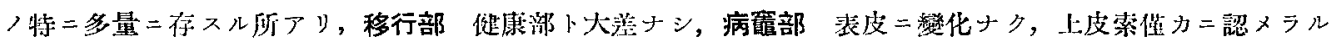

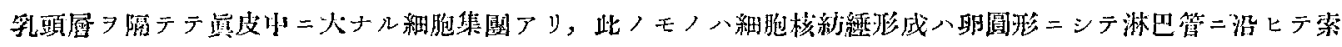

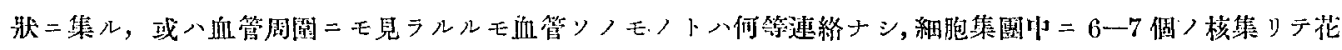

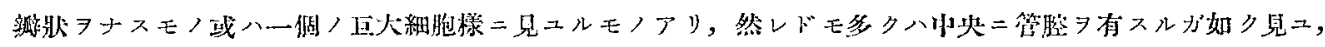

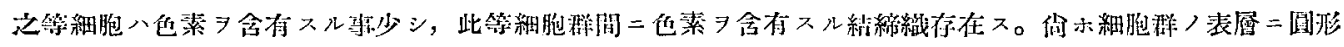

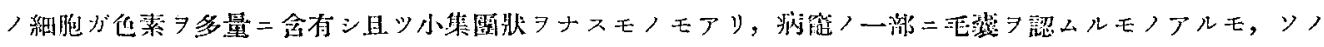

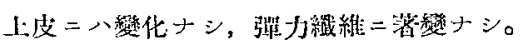

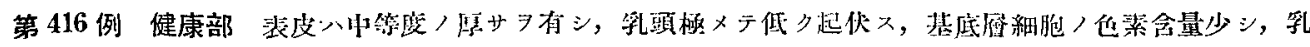

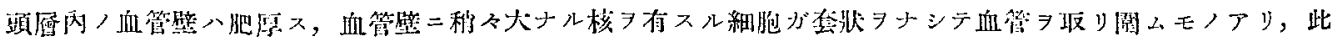

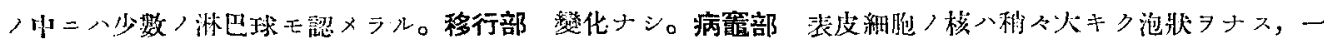

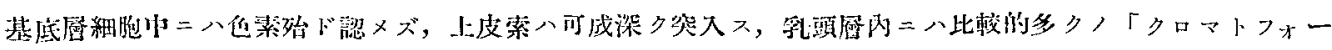

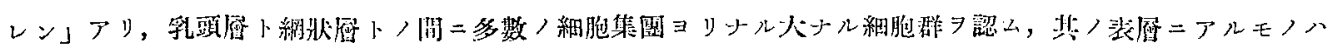

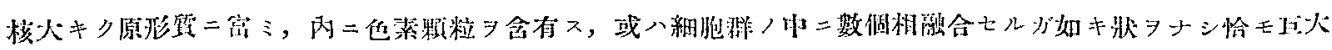

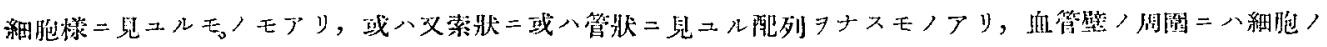

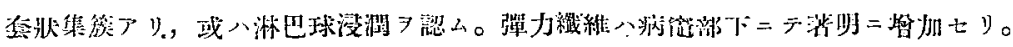

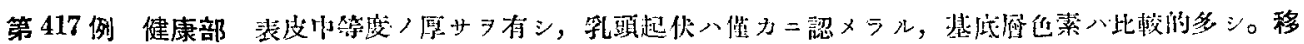
1038 


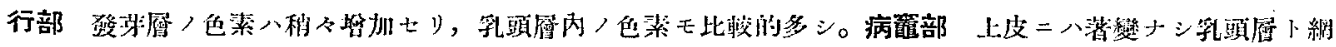

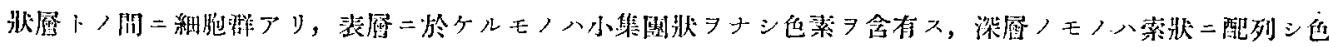

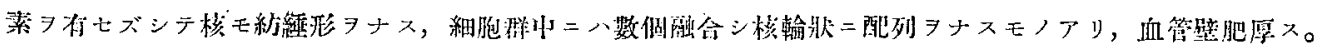

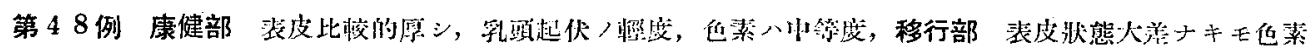

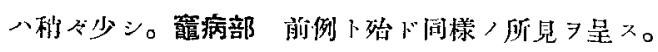

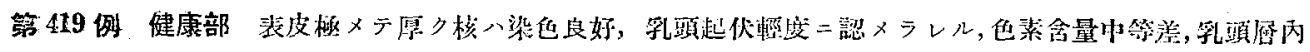

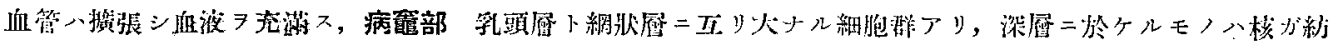

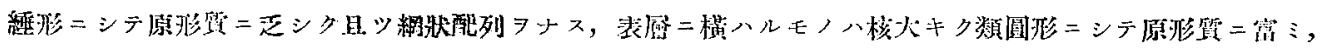

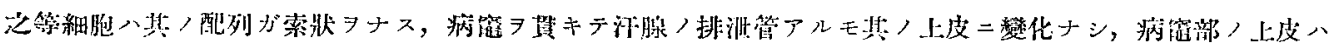

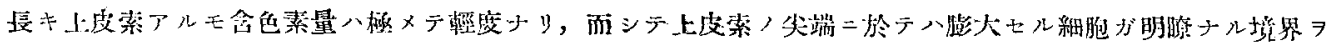

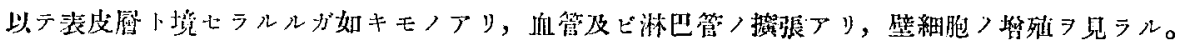

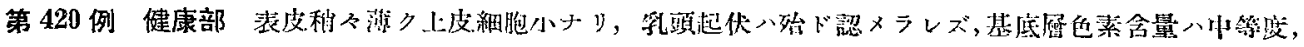

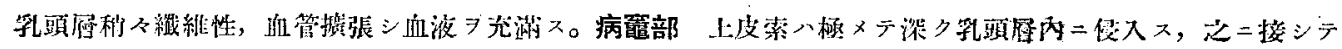

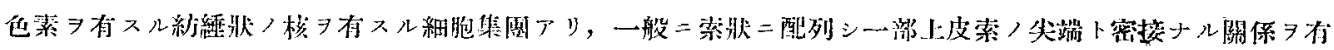
メルモアプ。

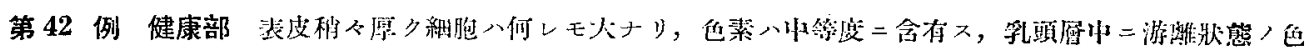

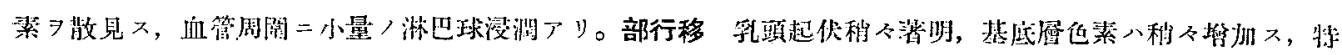

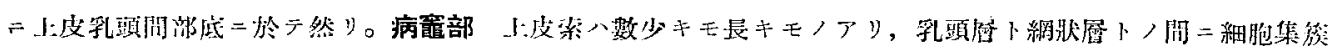

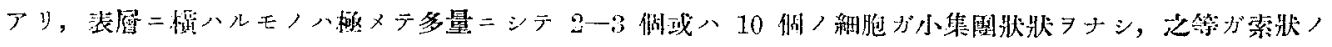
列ヨナシテ甚ラル。

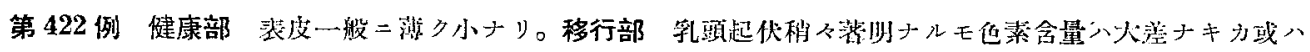

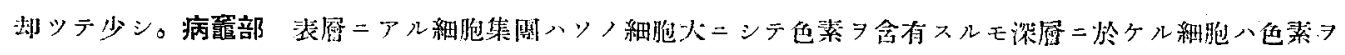

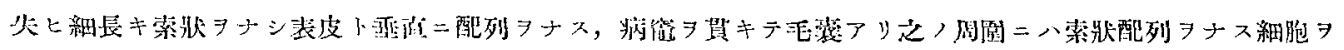

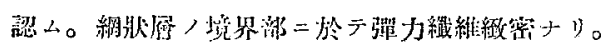

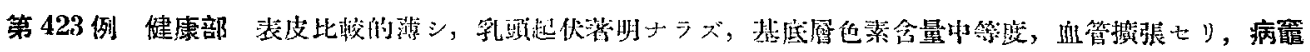

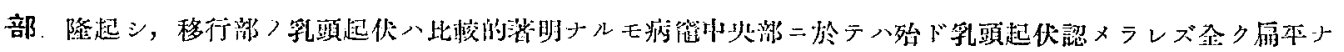

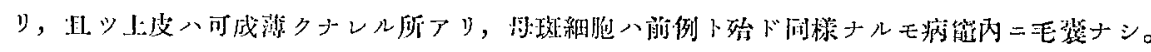

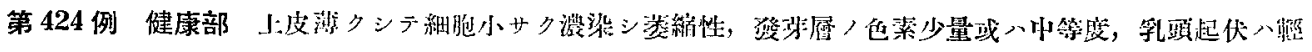

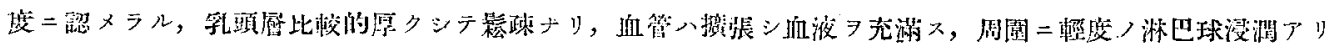

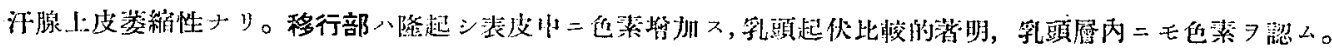

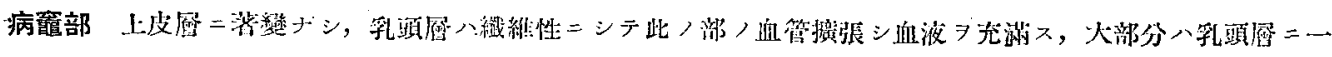

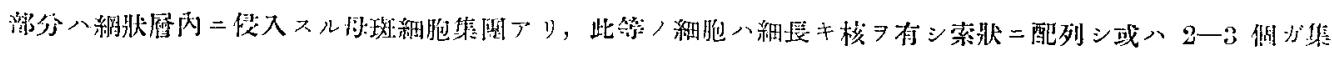
マリテ巨大細胞栐二見コルモノアリ。

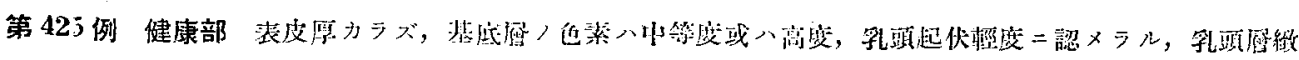

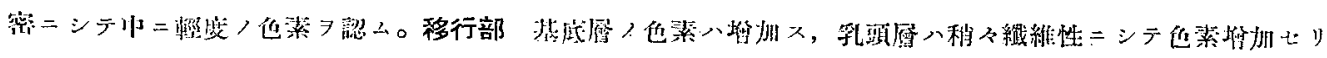




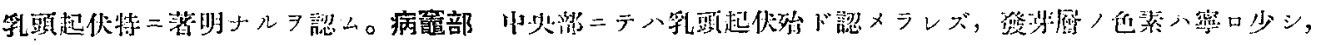

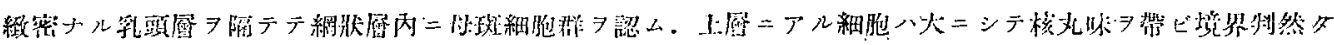

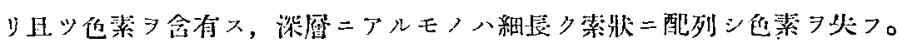

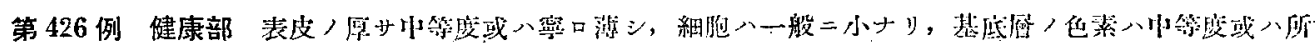

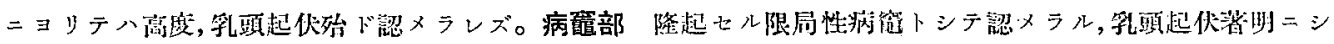

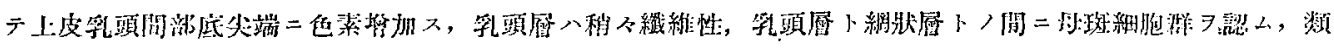

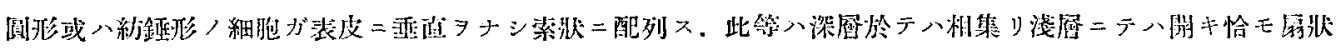

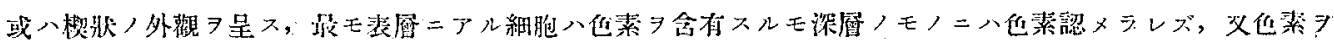

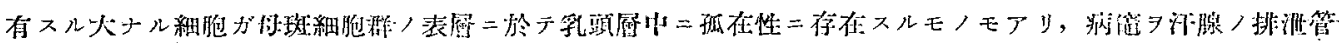
ガ貫ケルモ毛薪八認メシレズ。

\section{5. 第 五型}

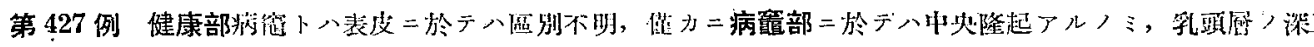

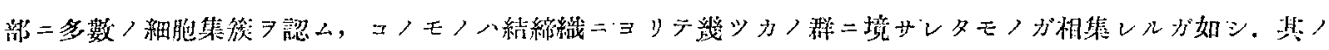

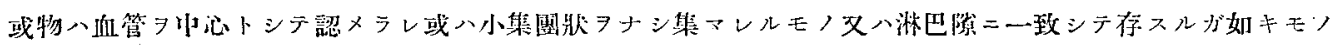

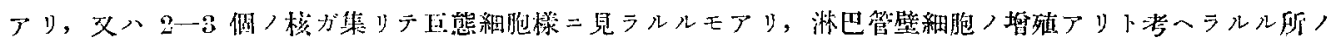

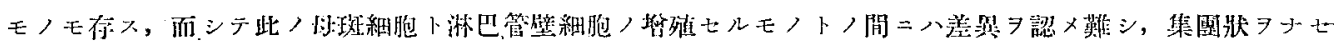
ル火ナル細胞,或物ハ他素习含有スレドモ其ノ他ハ一船二色素少シ。

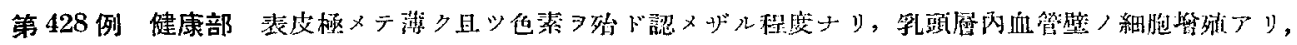

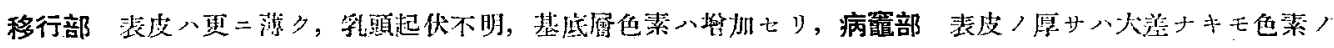

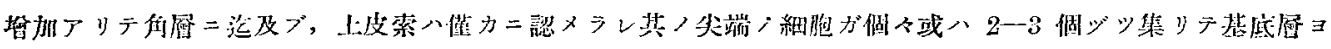

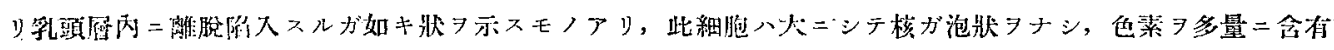

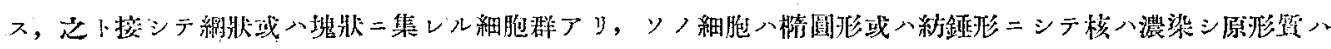

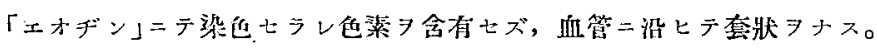

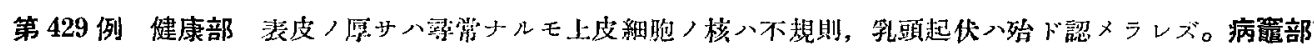

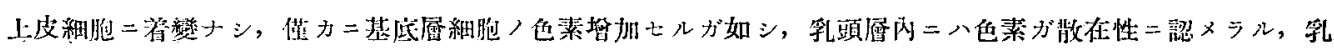

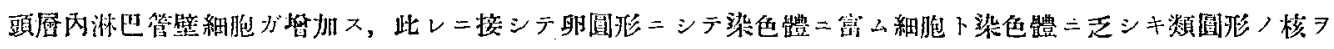

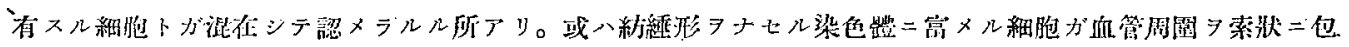
ンデ配列也ルタ・見ル，面シテ此ノモノ八色素习含有七ズ。

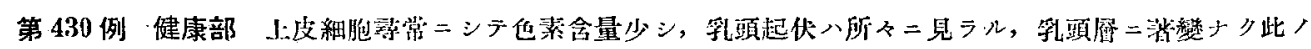

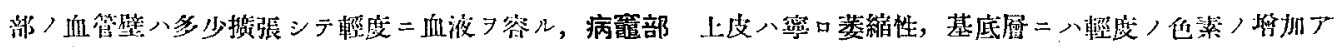

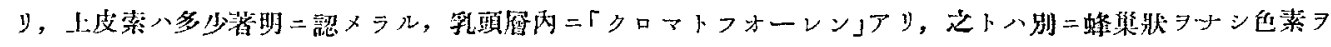

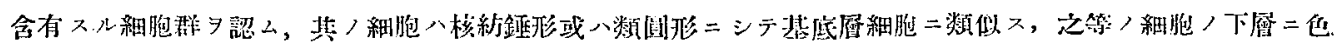

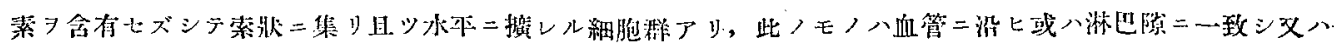

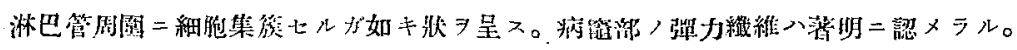

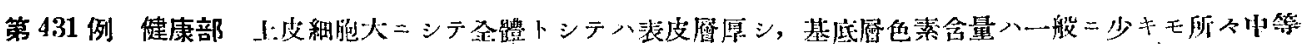




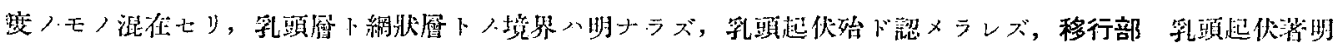

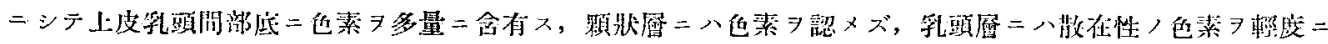

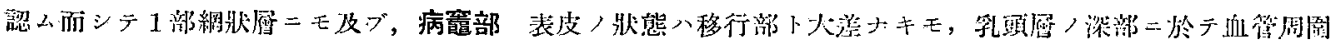

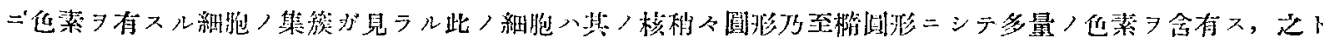

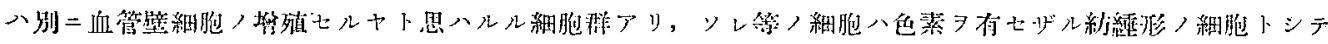

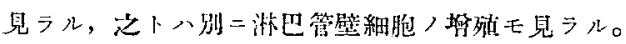

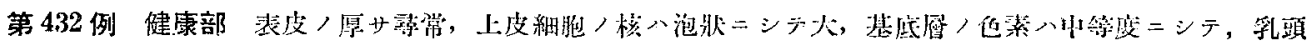

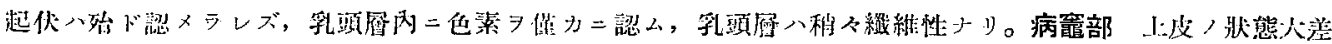

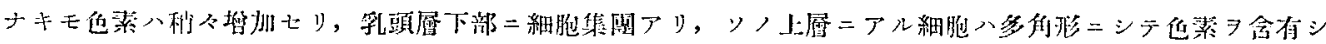
下䂺ニアルモ, 八禁状二配列シ色素少シ。

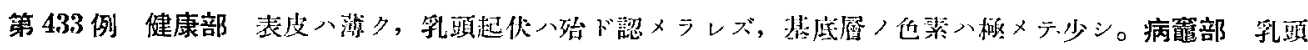

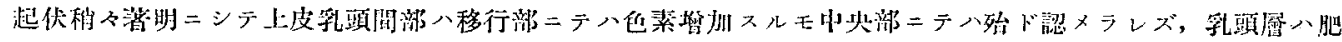

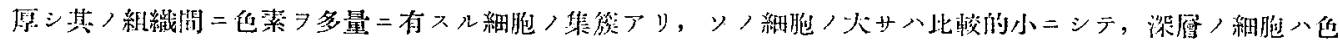

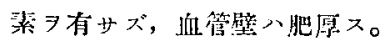

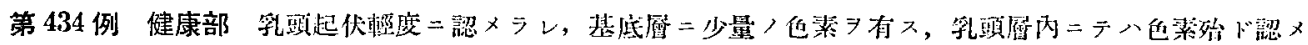

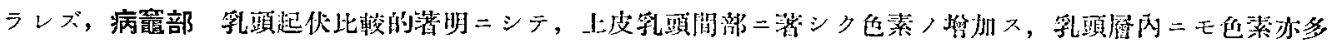

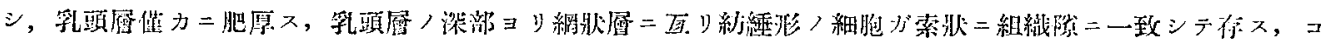

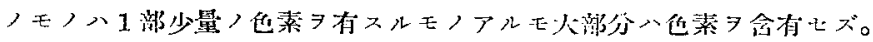

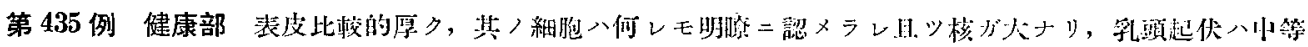

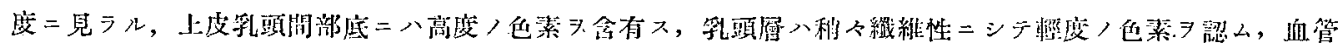

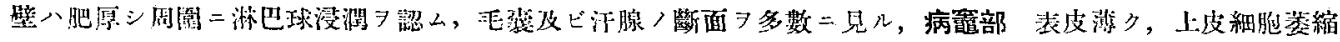

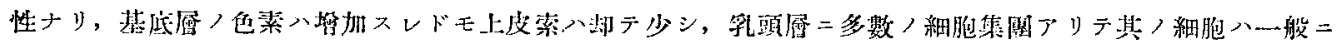

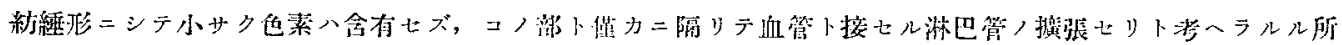
アリ，其，周图二多量，色素 $习$ 見儿

\section{6. 第六 型}

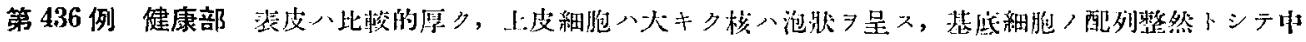

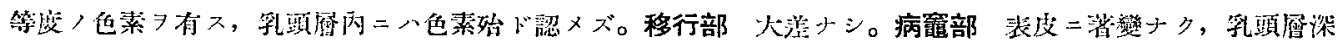

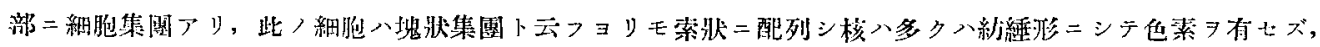

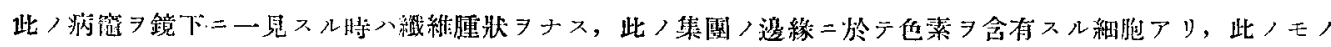

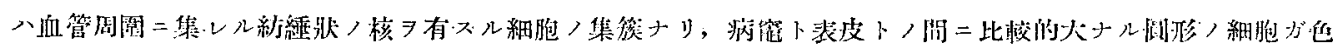
秦ヨ眲取シテ存スルモノモアリ。

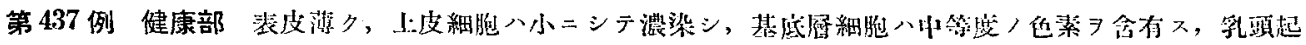

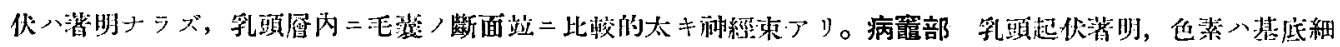

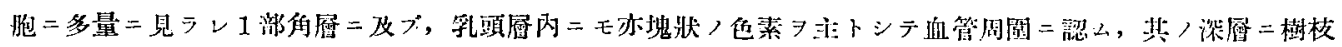

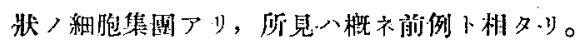




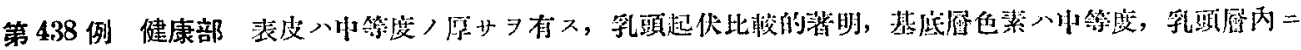

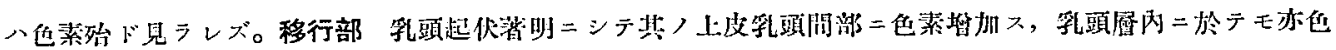

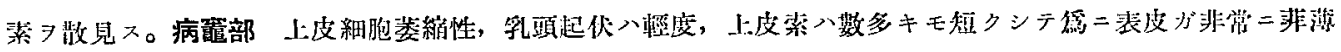

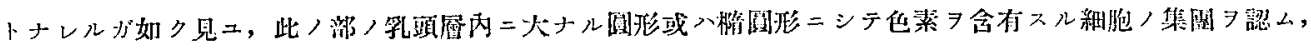

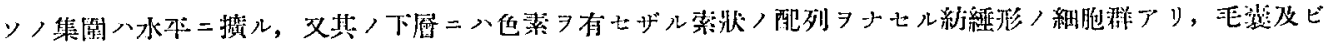

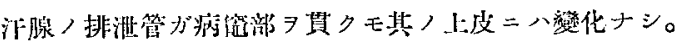

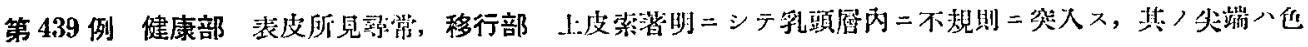

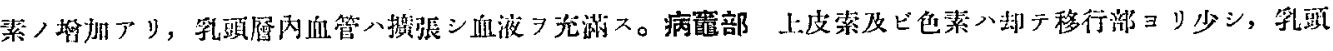

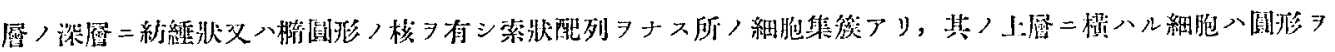

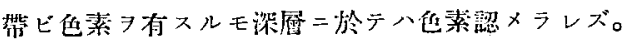

\section{7. 第七型}

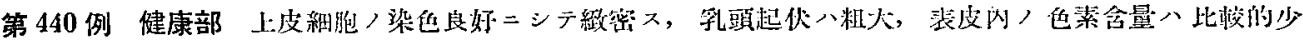

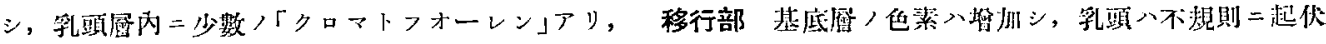

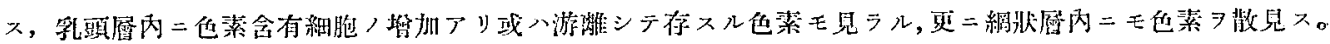

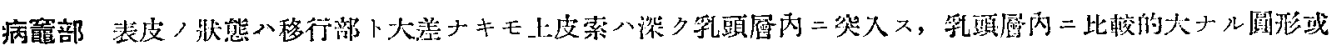

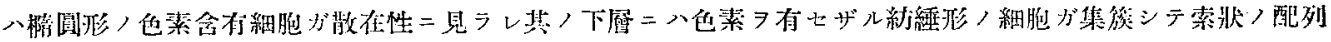
シナス。

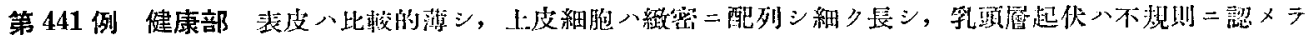

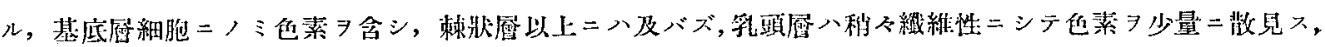

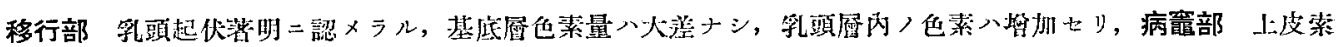

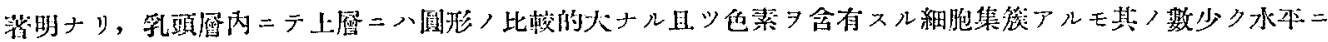

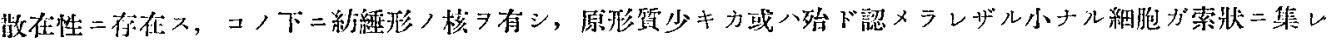
ルョ見ル,此ノモノ八色素习含有七ズ。

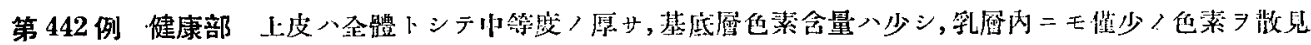

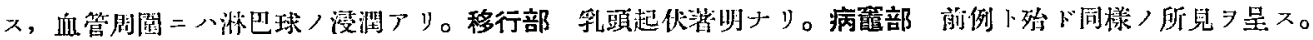

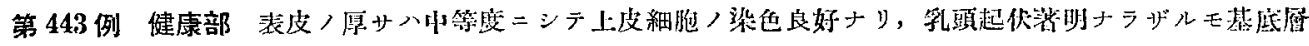

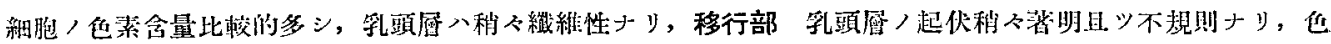

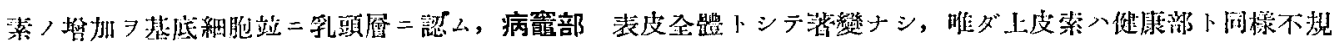

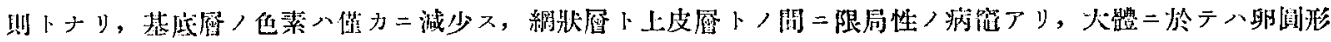

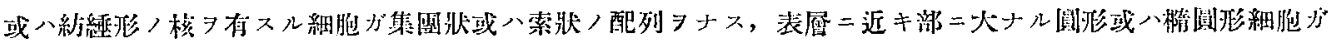

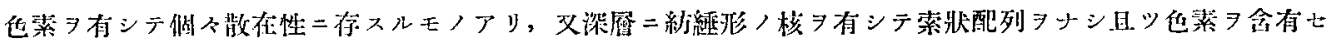

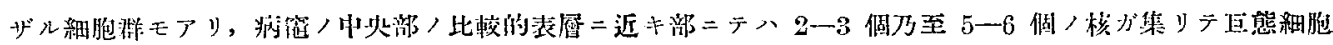

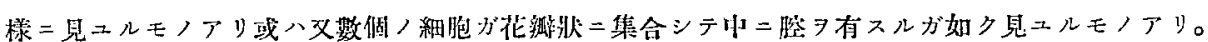

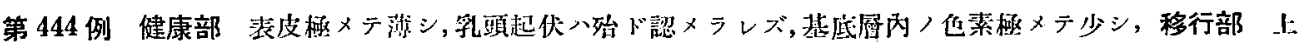

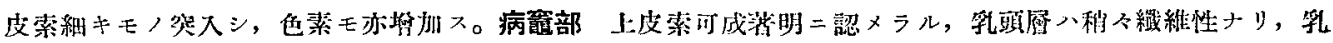




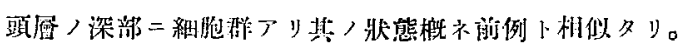

\section{8. 特 殊 型}

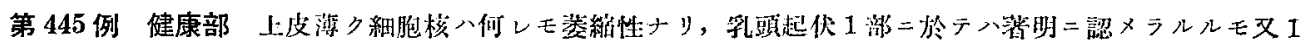

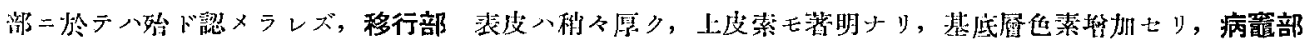

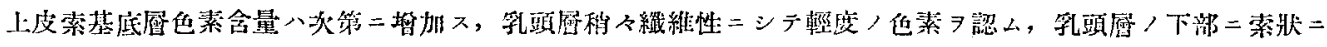

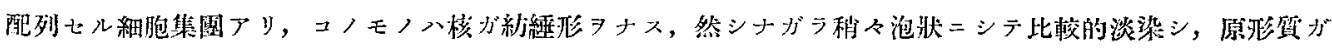

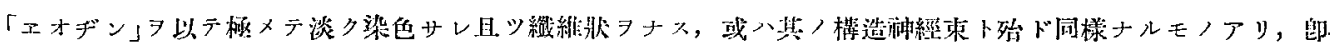

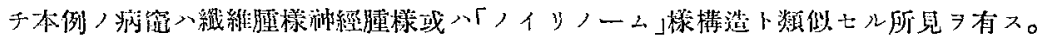

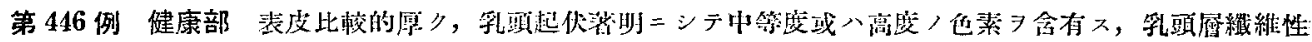

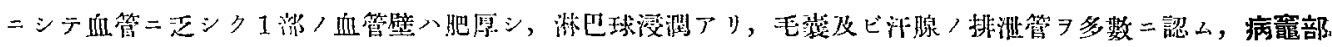

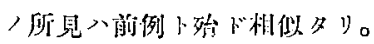

\section{(八) 例 外}

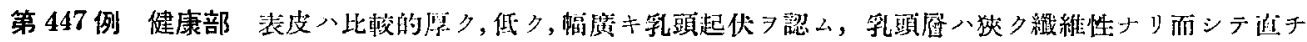

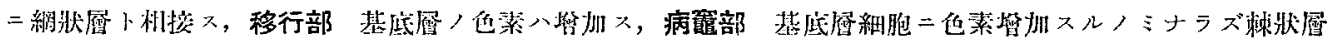

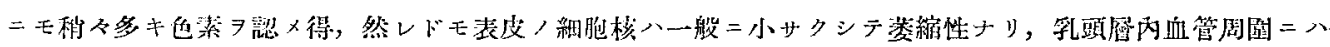

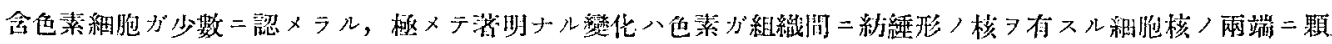

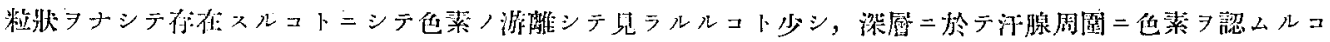

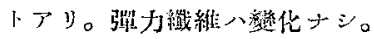

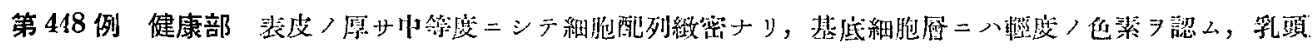

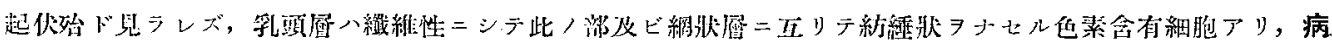

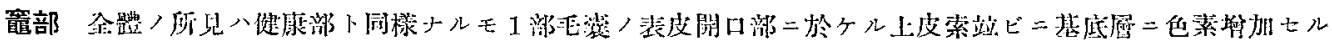
モノアリ。强力維維揫化ナシ。

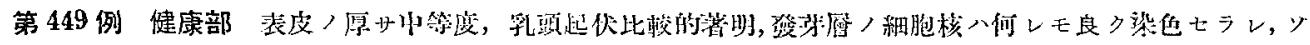

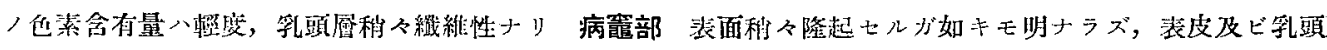

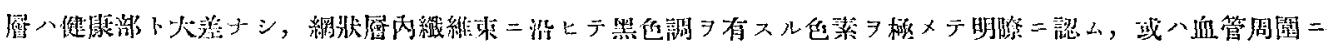

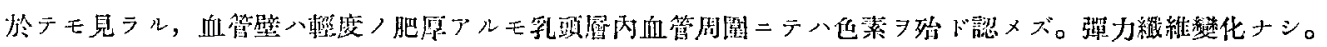

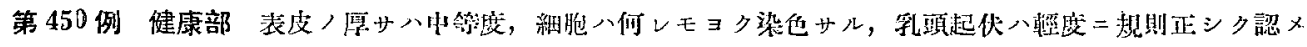

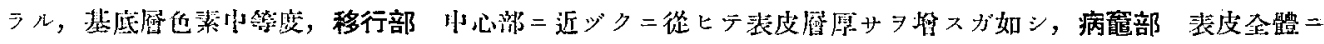

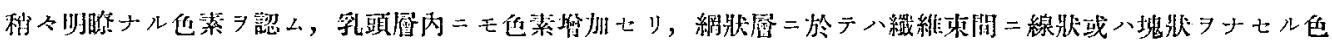

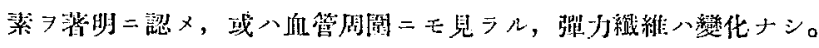

\section{第 5 章 䂰究例所見總括}

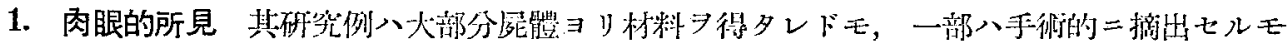

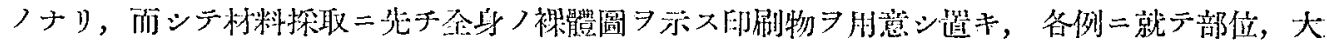

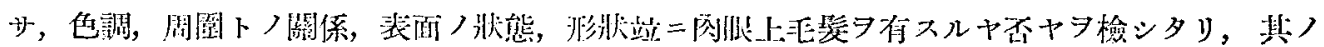


得儿所八概市次ノ如シ。

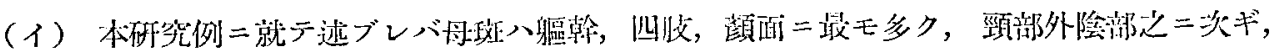

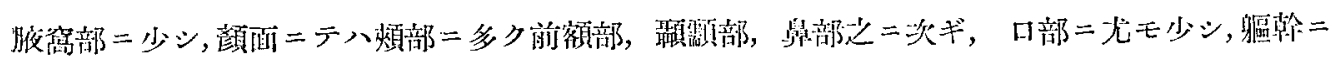

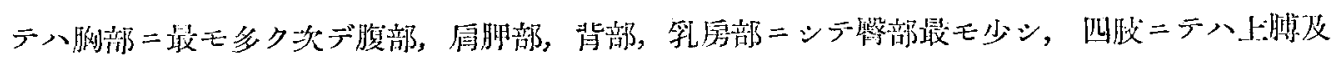
大腿部二多ク枨秒部二進ム二從ヒテ少シ。

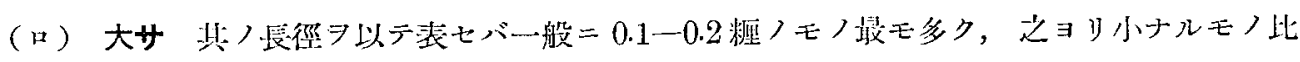

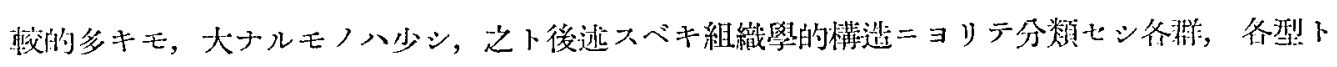

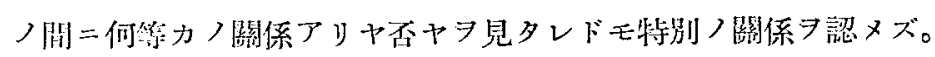

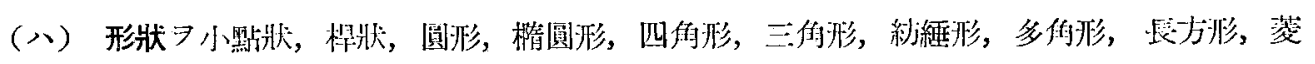

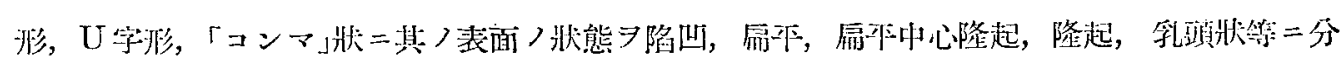

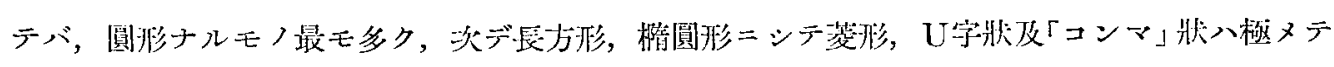

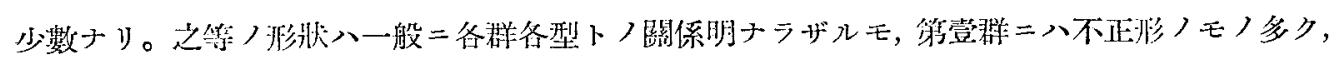

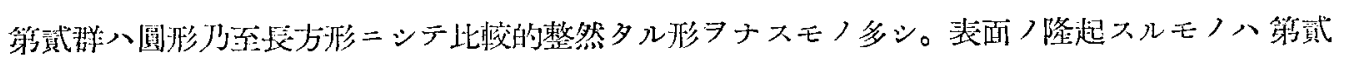

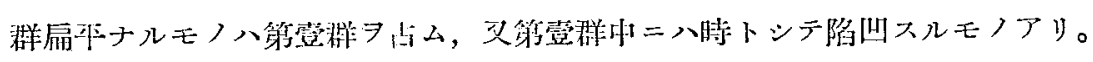

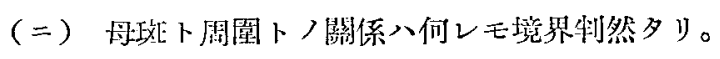

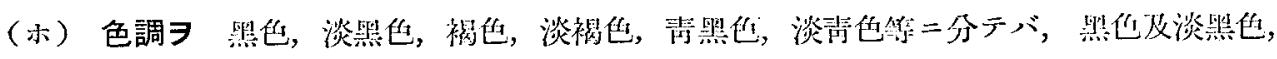

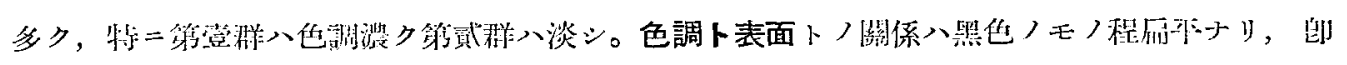

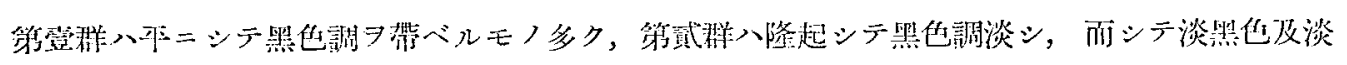
毒色ノ如手色調淡キモノ八始ド觜隆起七り。

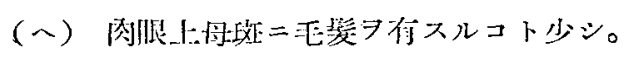

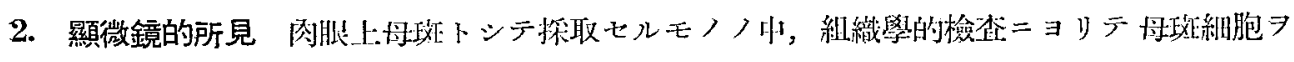

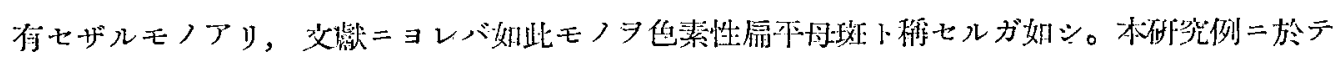

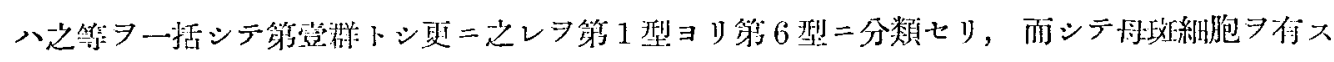

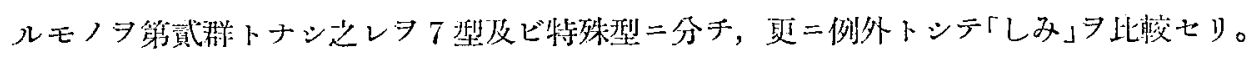

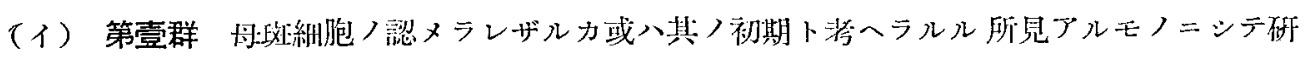

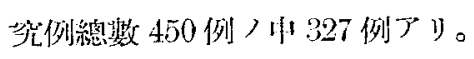

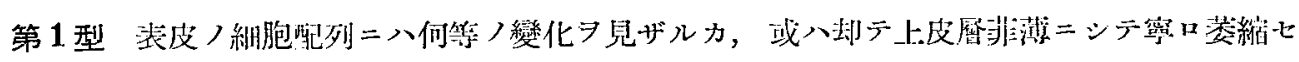

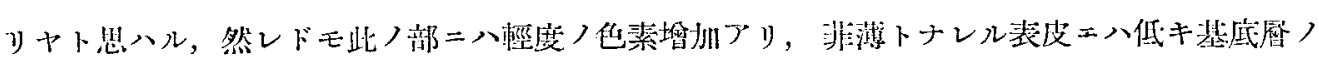

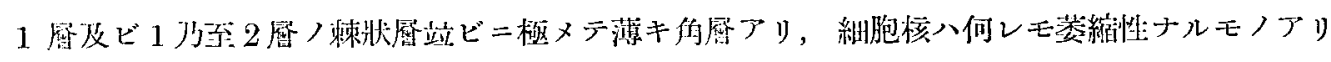

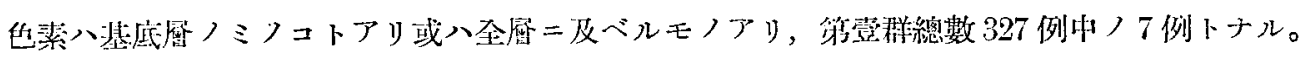

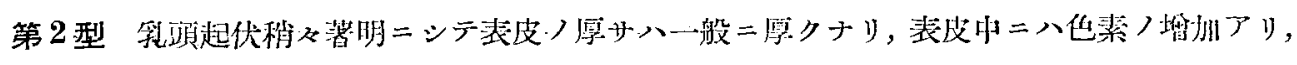

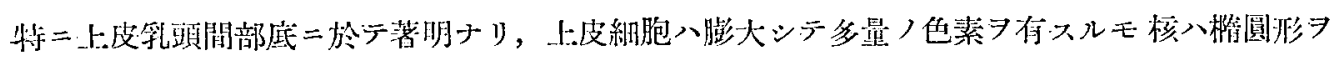
ナスモノア゙リ，75例二於テ見ラルル。 


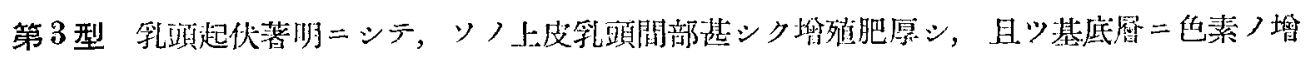
加認ムルモノンシテ22 例疗大。

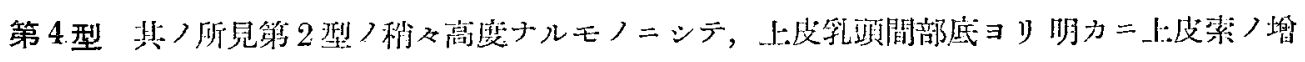

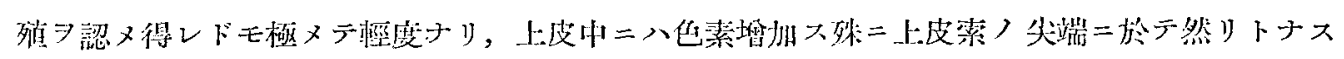
モノ 77 例二於テ見ラル。

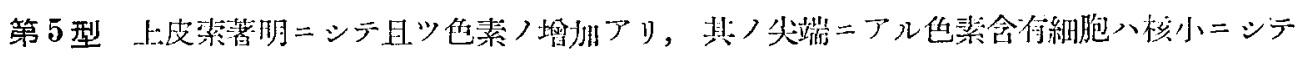

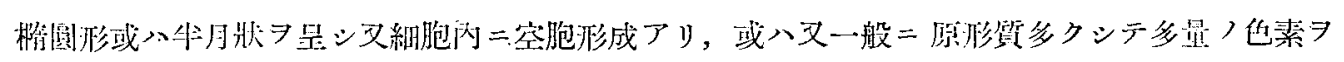

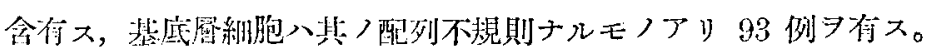

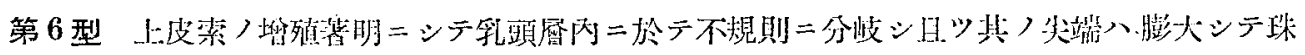

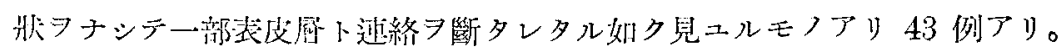

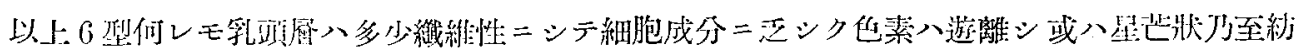

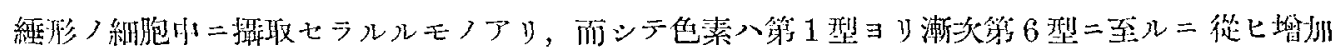

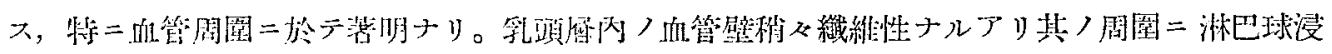

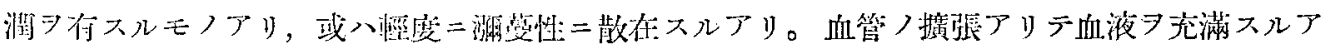

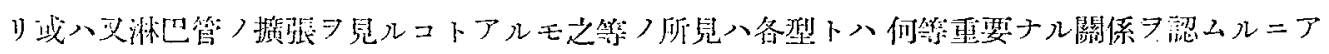
ラザルガ邚シ。

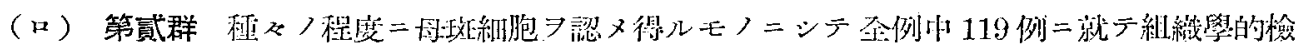

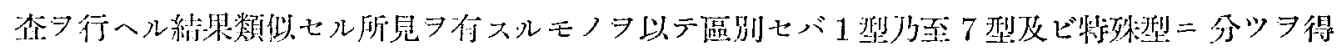
可シ。

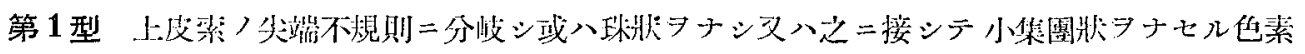

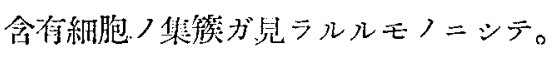

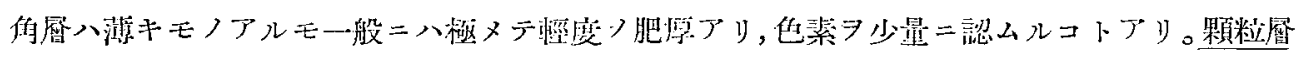

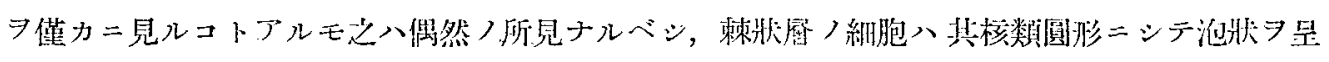

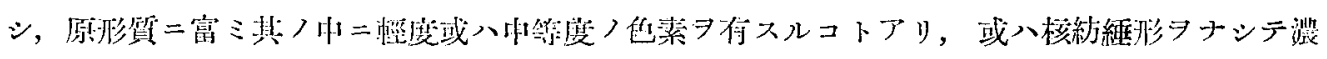

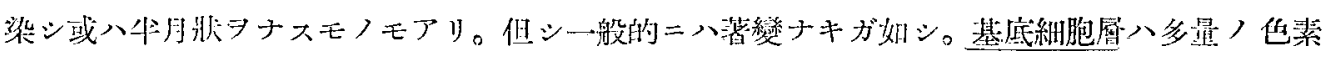

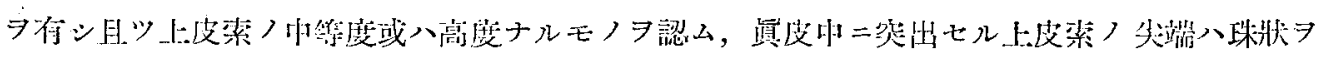

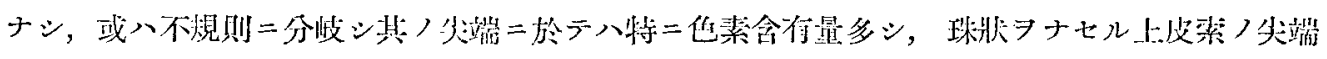

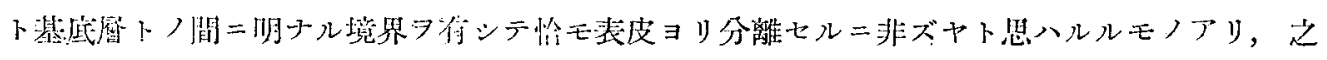

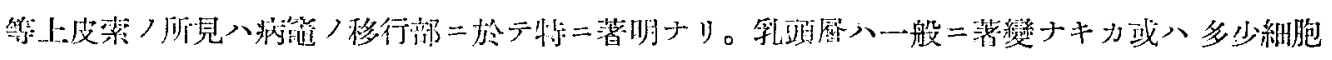

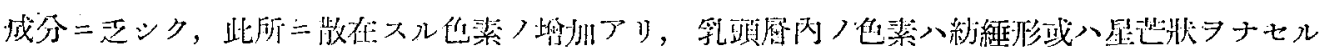

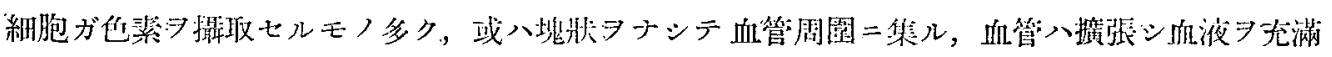

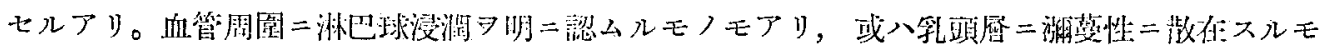

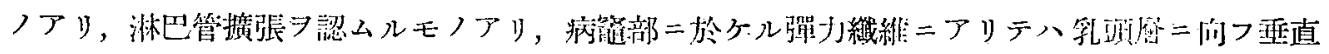




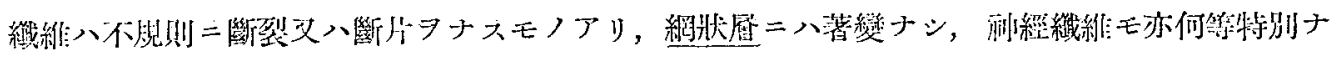

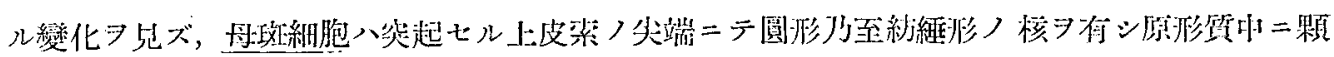

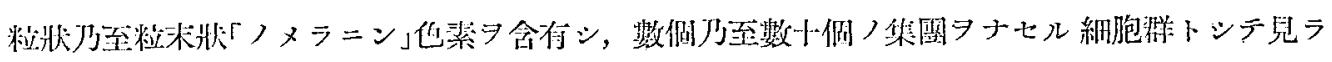

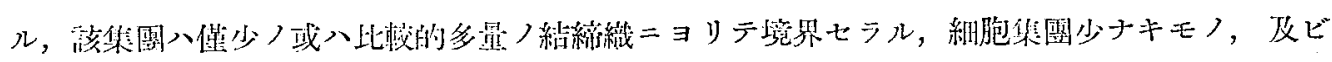

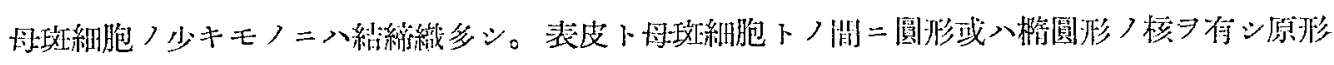

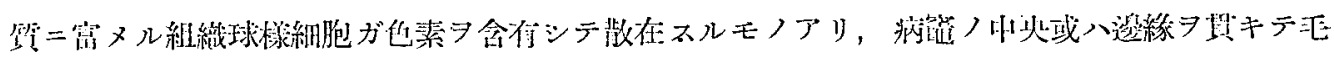

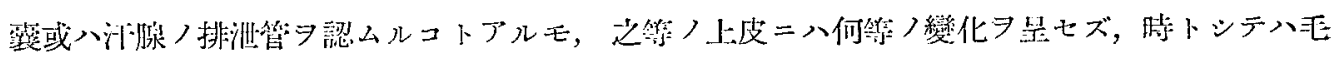

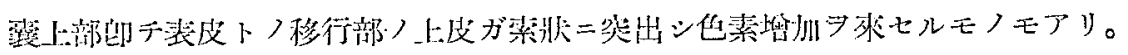

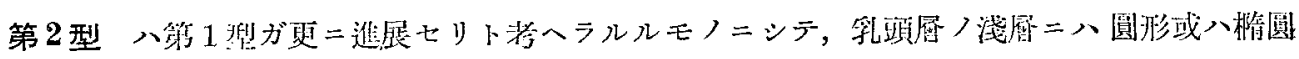

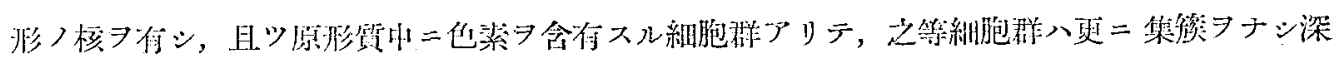

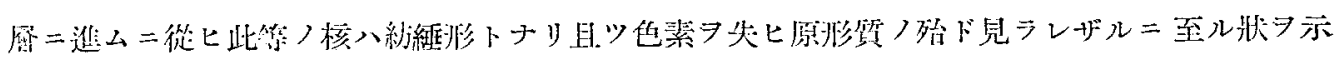
スモノナリ。

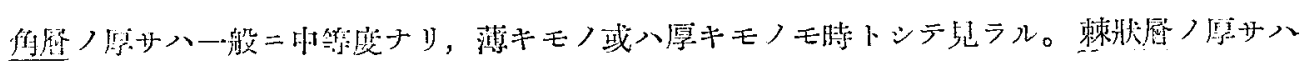

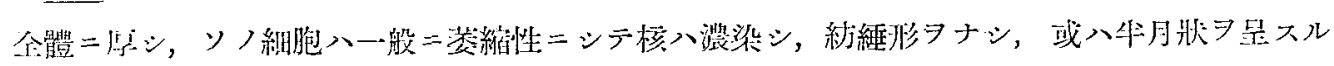

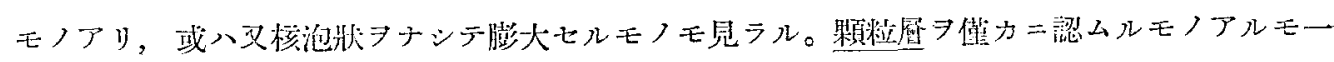

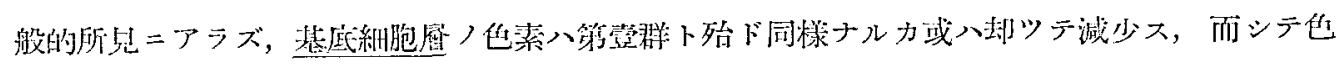

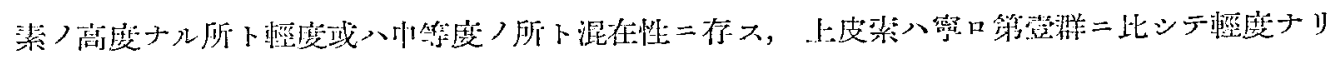

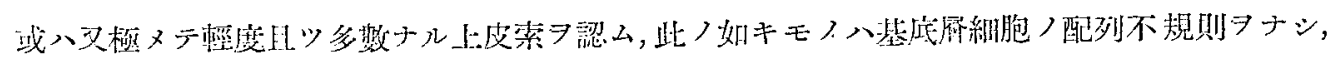

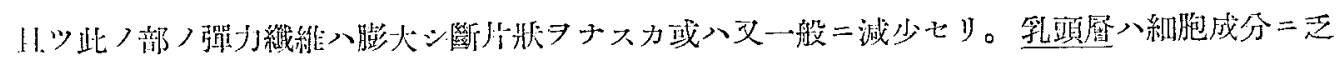

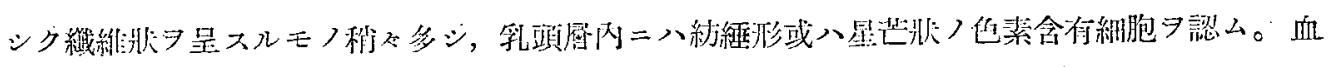

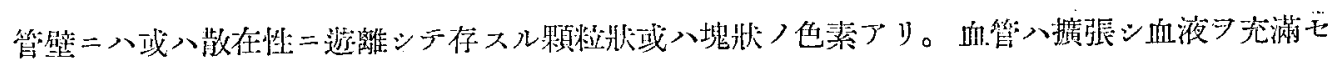

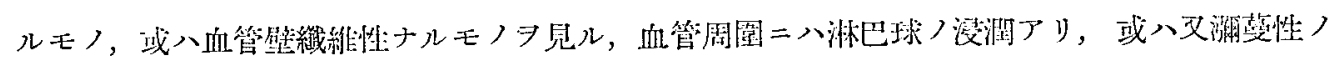

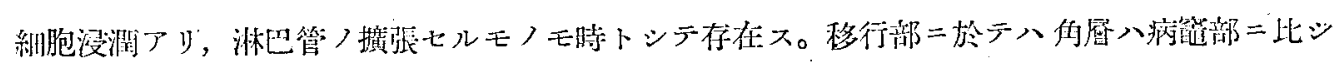

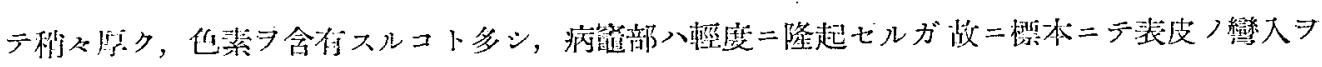

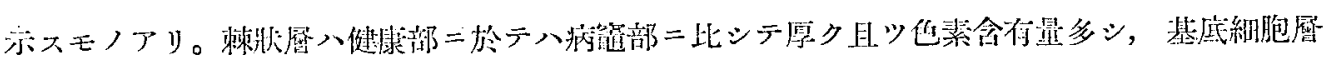

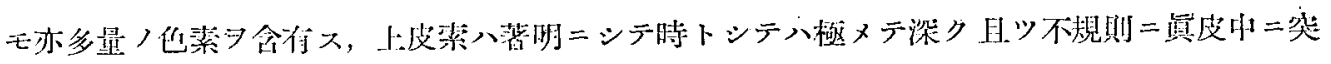

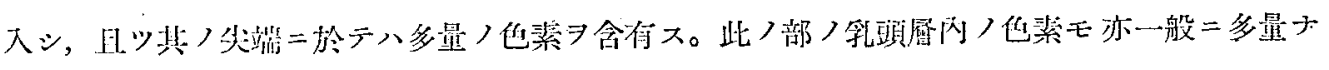

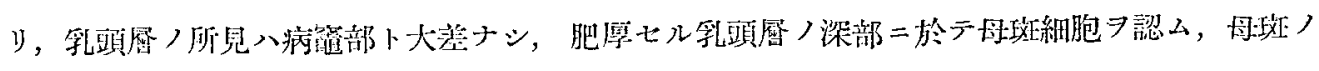

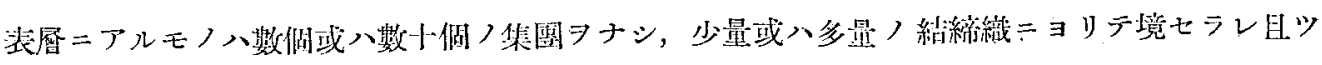

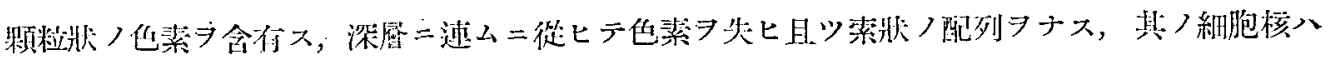

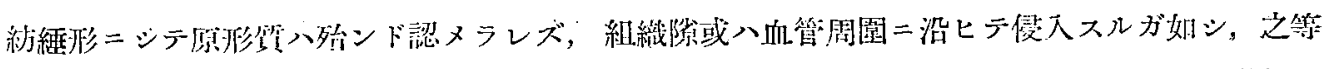

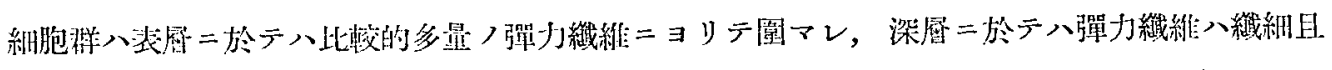

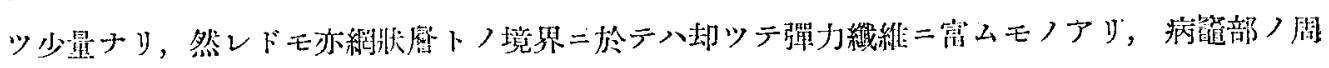




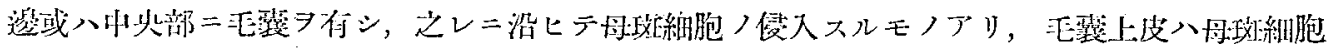

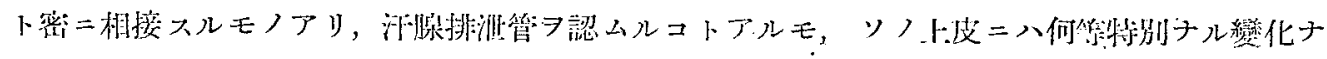
シ。

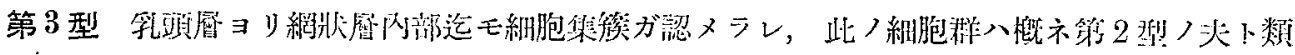

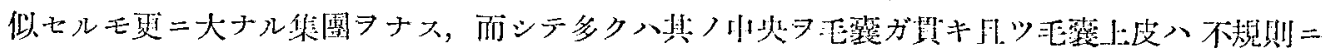

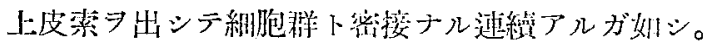

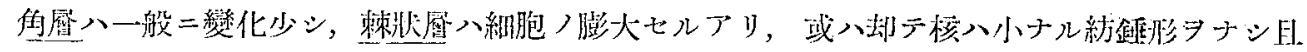

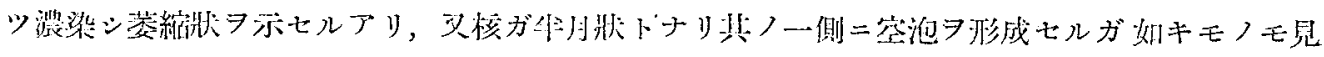

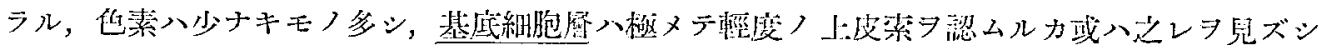

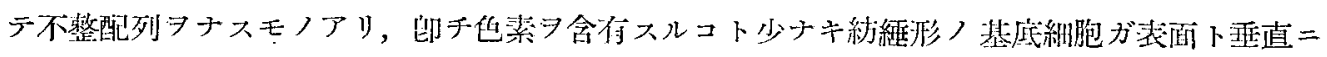

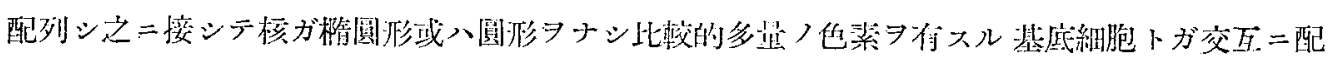

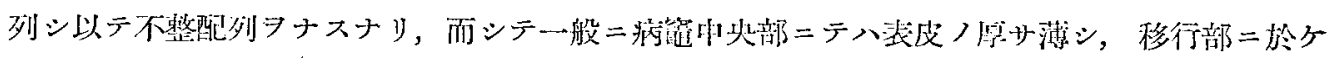

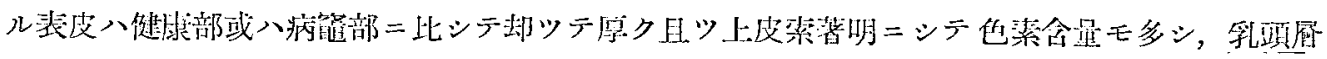

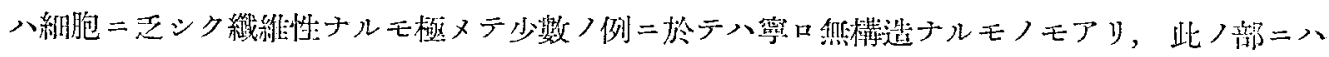

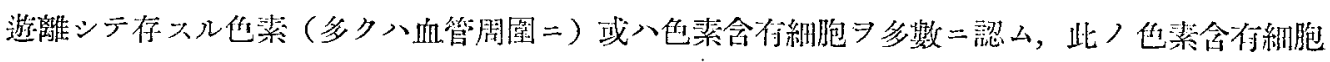

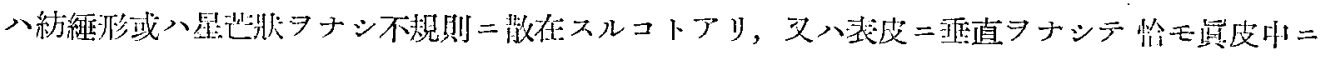

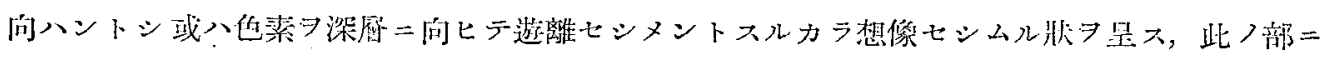

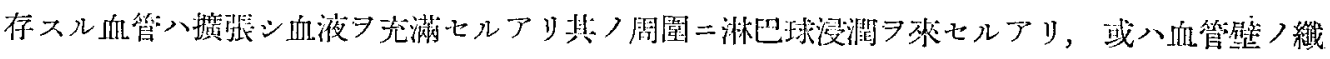

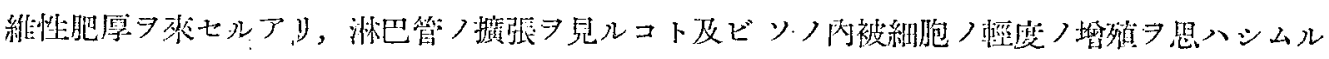

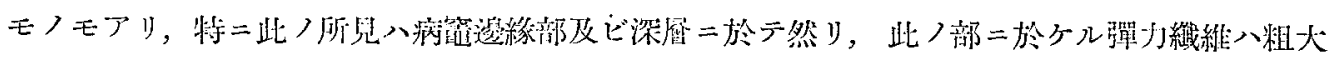

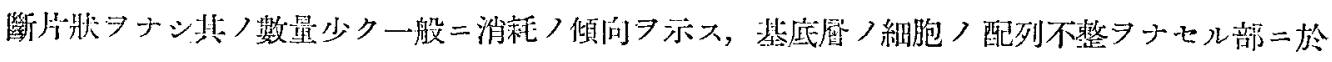

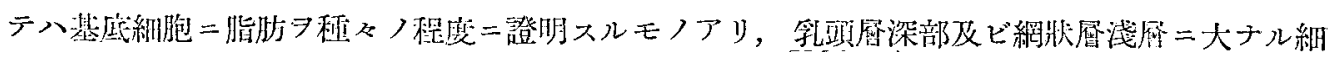

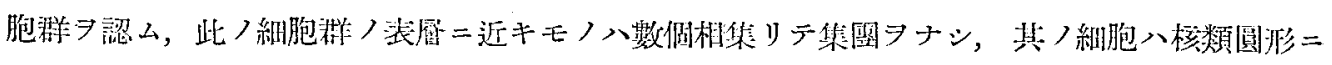

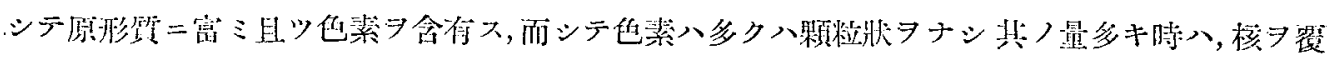

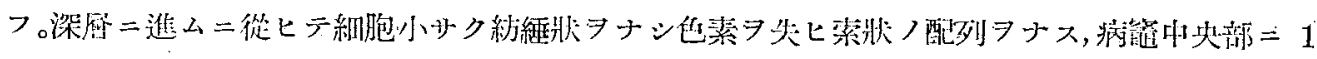

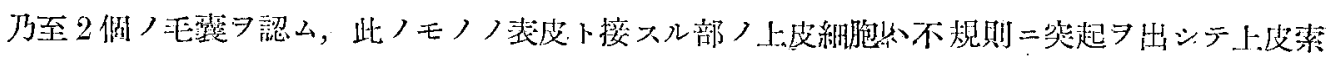

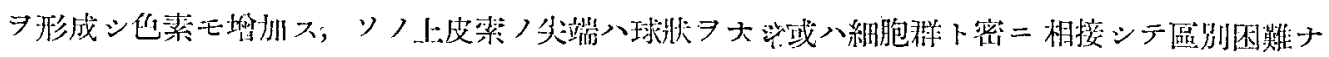

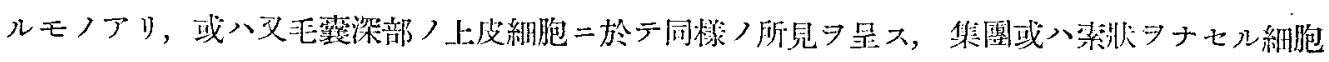

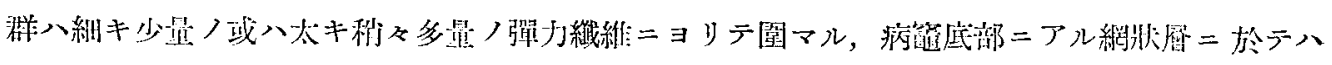

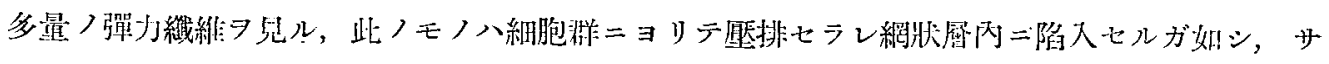

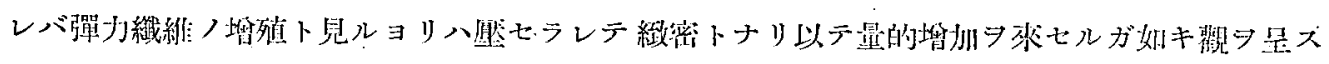

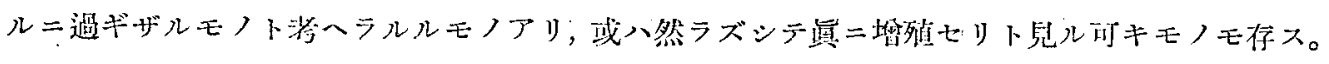

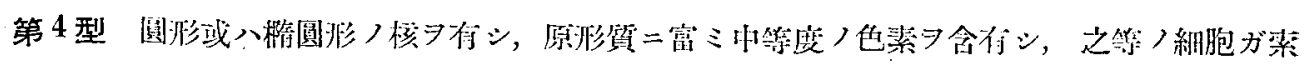




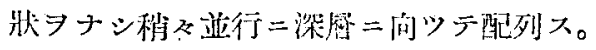

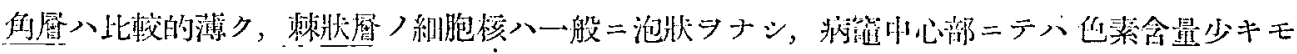

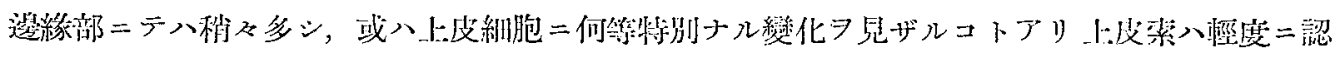

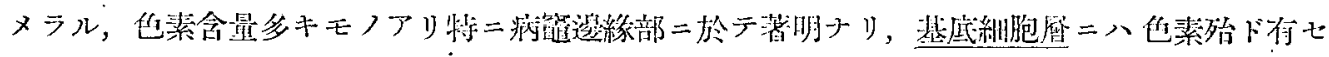

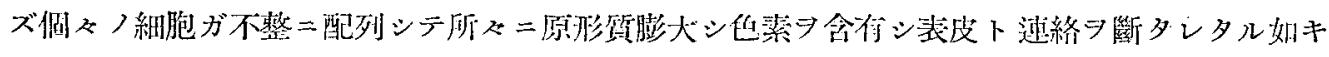

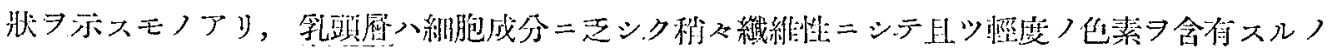

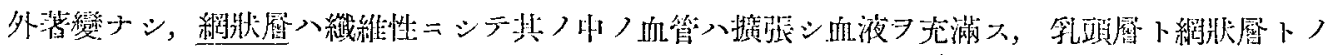

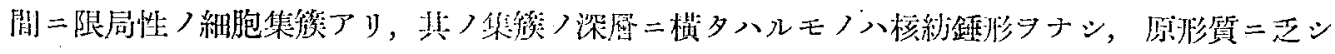

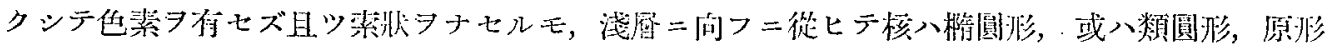

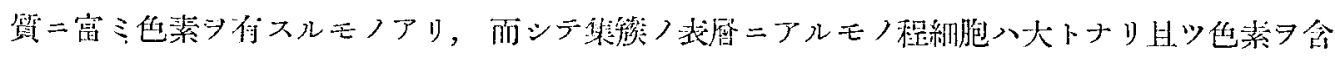

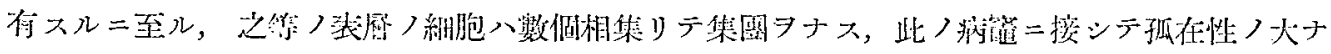

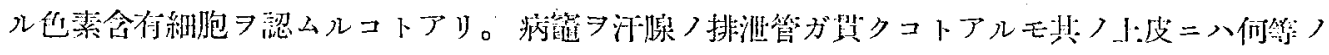
變化ナシ，淋巴管〉㵠张七ルモノタ認ムルコトアリ。

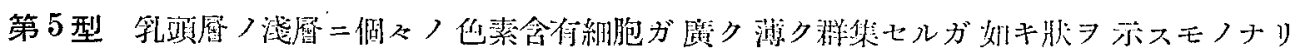
(他型ノ如ク密接ナル細胞集族ヨナサズ)

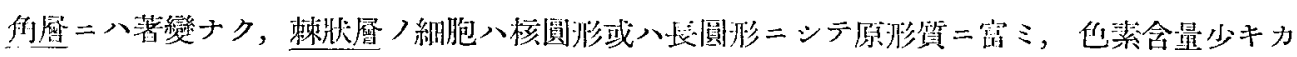

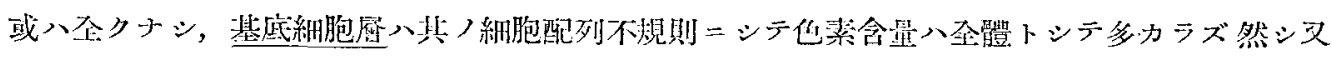

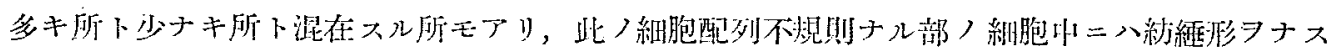

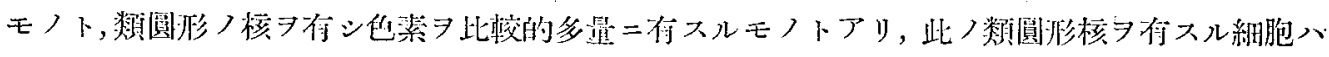

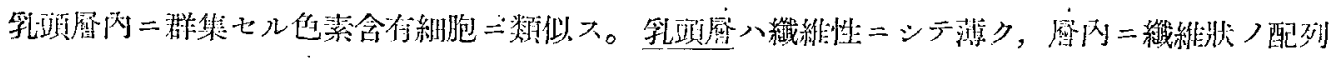

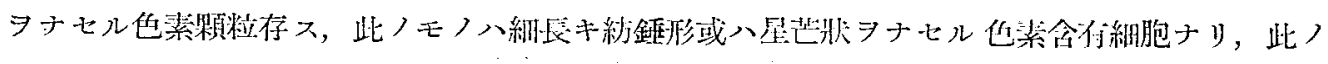

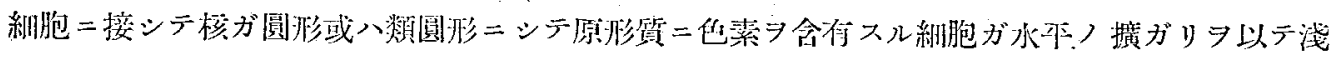

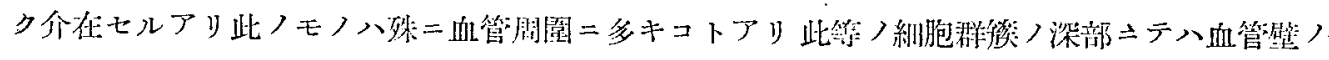

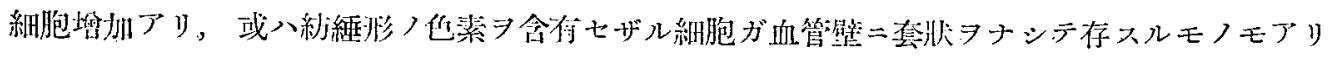

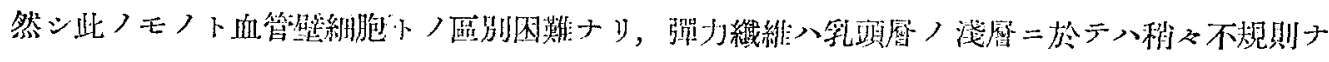

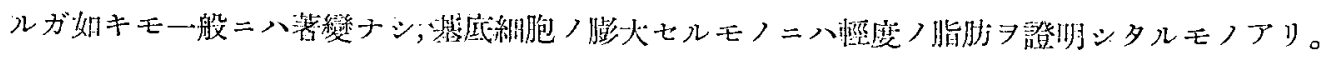

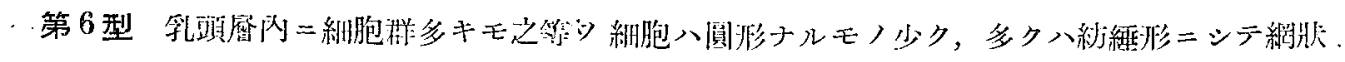
或八装状配列

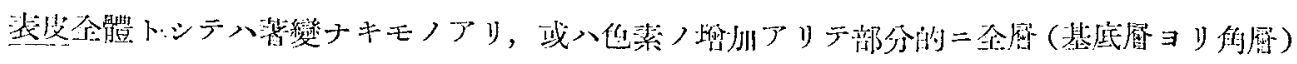

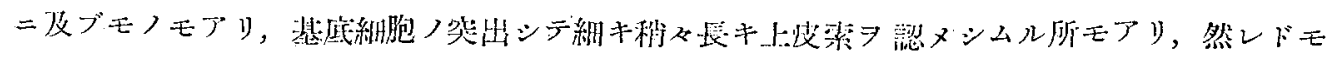

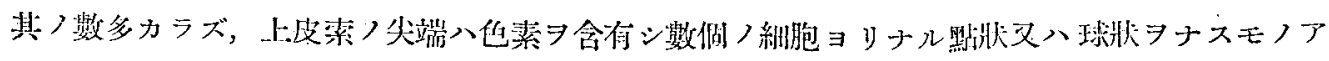

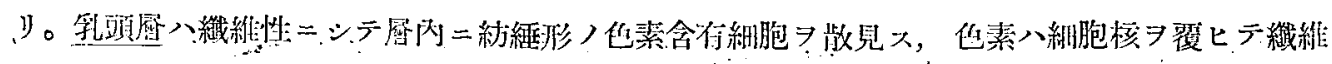

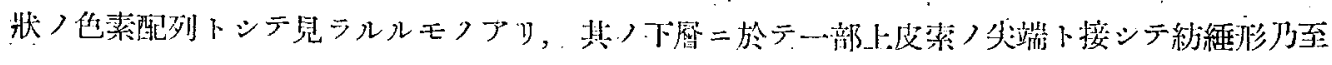




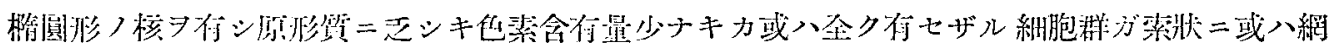

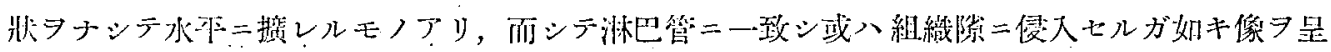

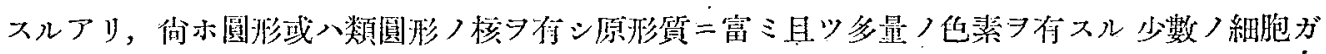

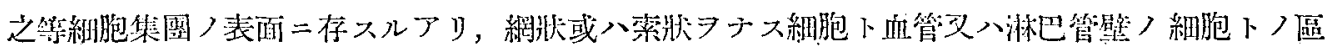

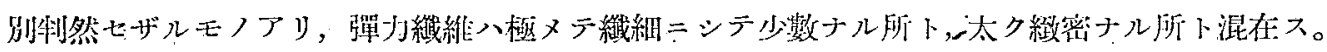

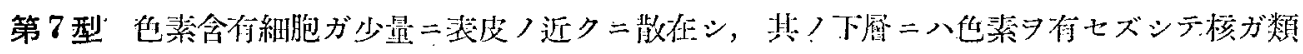

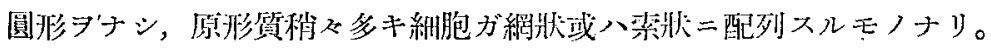

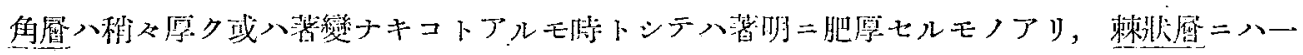

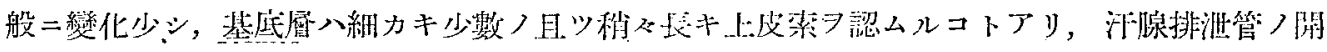

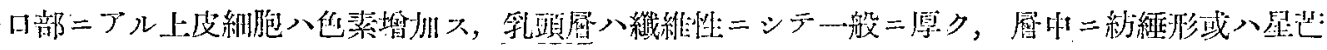

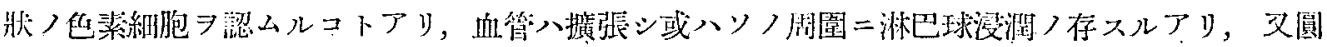

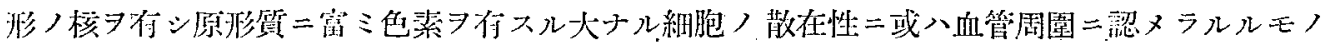

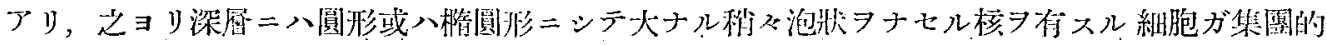

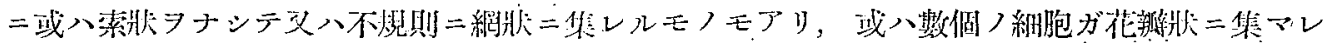

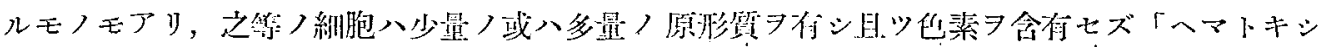

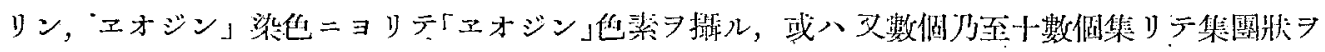

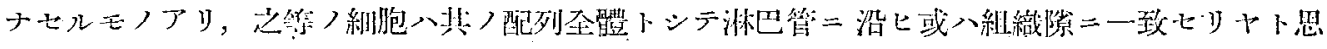

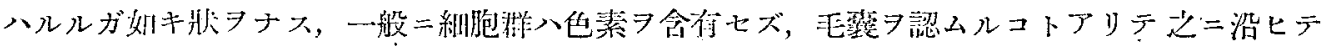

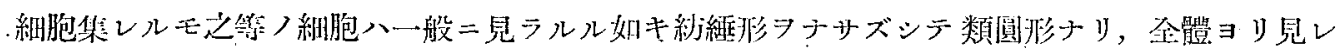

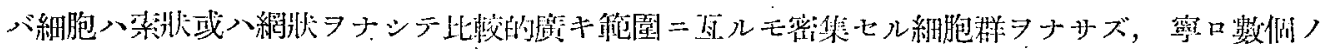

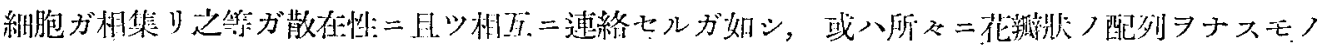

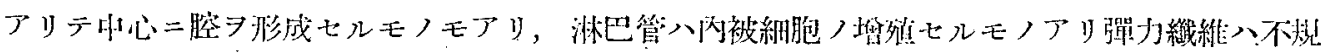
剘二衿メラル。

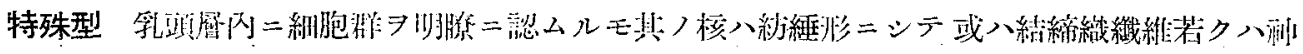

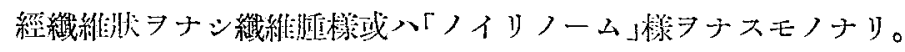

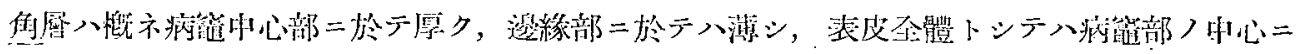

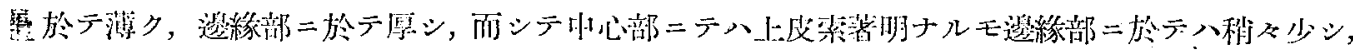

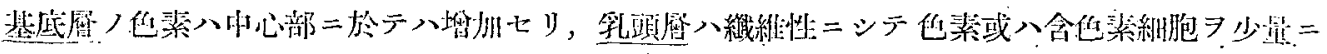

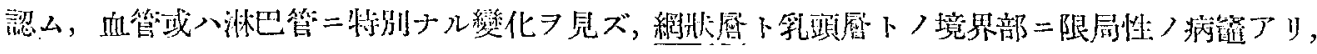

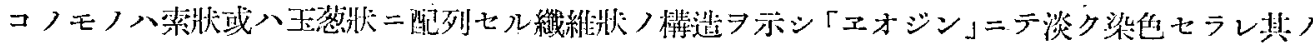

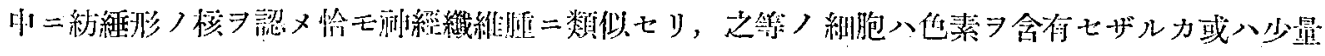

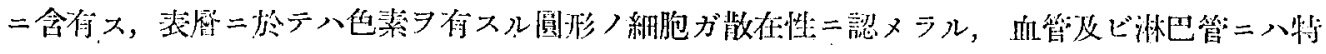
测ナル變化ナシ。 


\section{例 外}

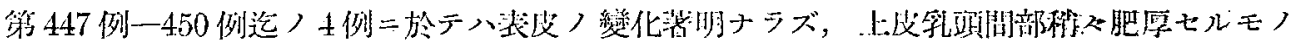

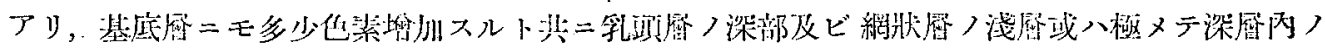

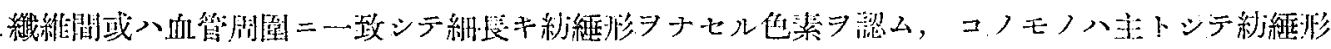

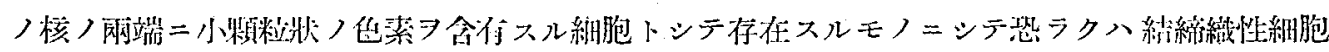

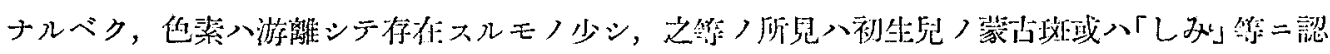

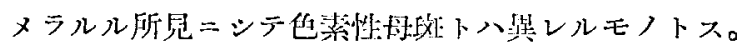

\section{第6 章 考按}

\section{(1) 肉眼的所見二付テ}

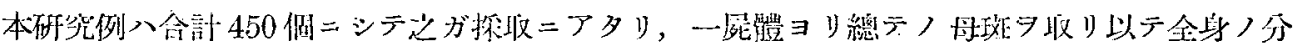

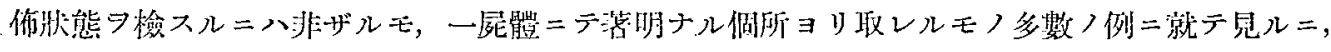

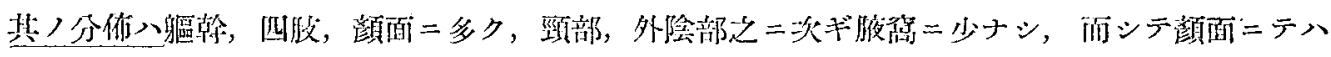

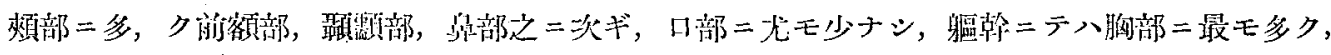

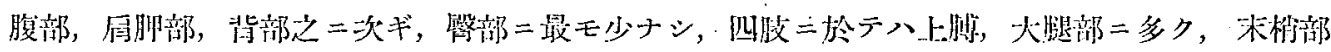

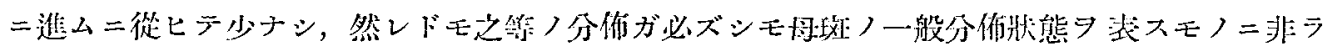

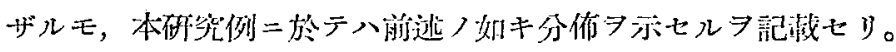

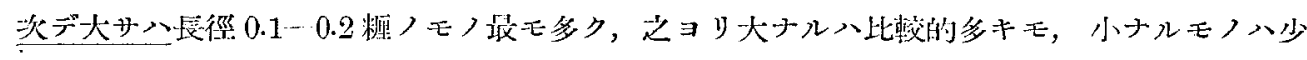

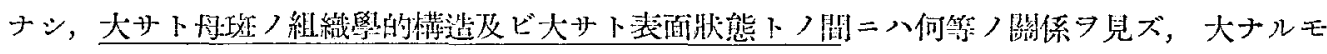
ノニモ日玟細胞ノ多キモノ或ハ少ナキモノアリ。小ナルモノニモ厓玫細胞多キアリ或ハ少ナキ

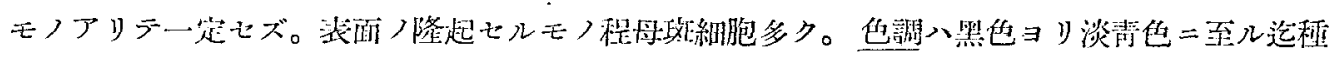

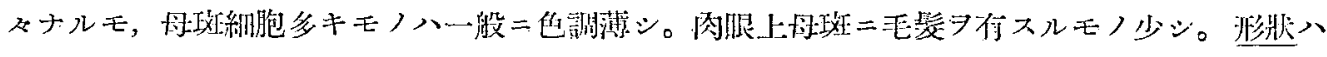

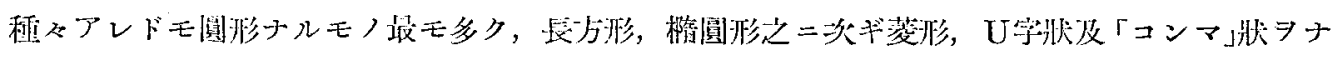

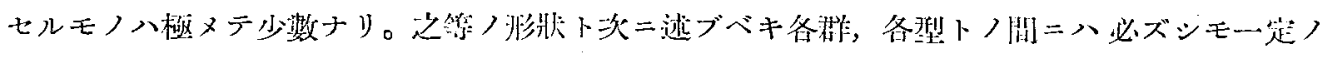

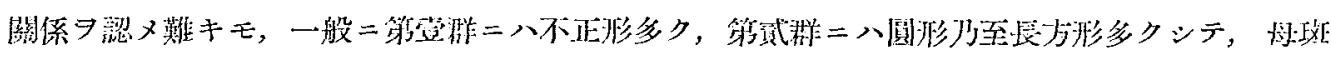
綝胞多キモノ程整然タル形状フナスガ如シ。

\section{（二）組織舀的構造:ヨル分類ニ就テ}

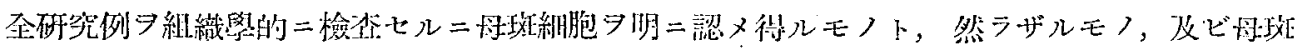

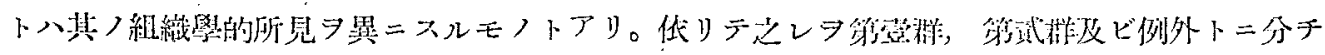

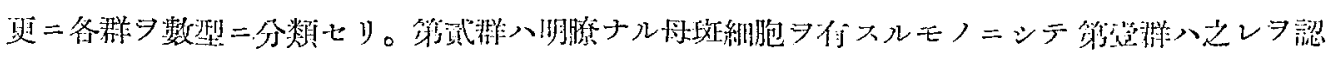

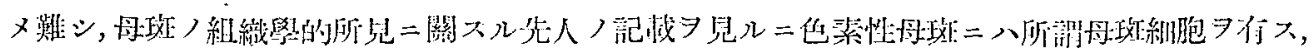

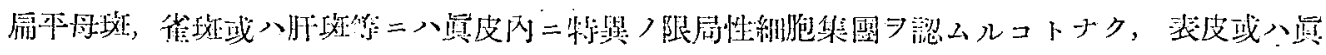

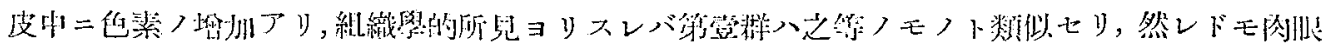

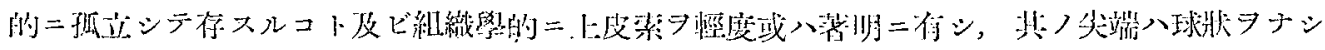




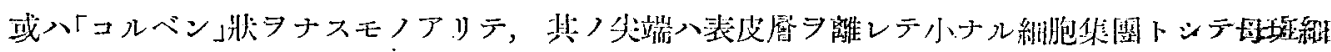

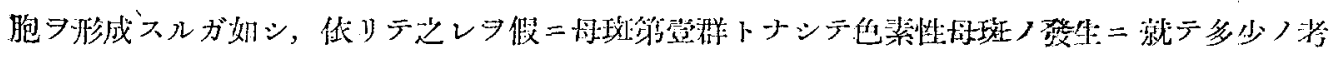

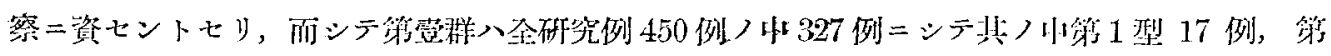

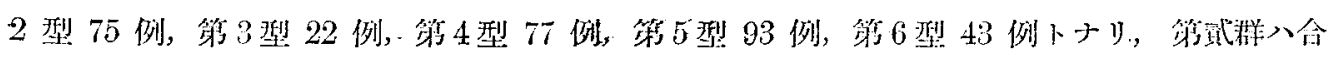

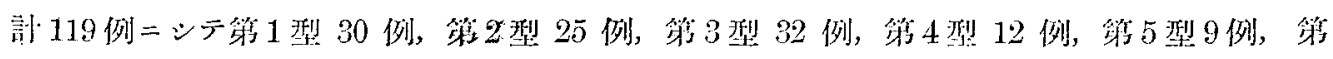

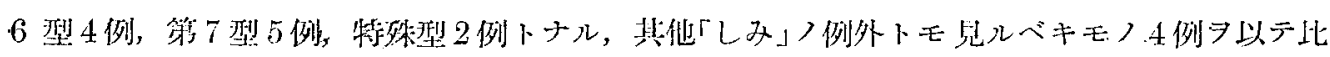

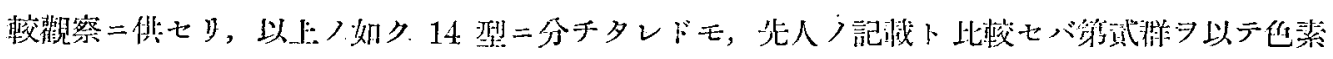

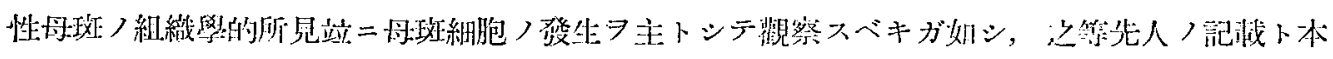

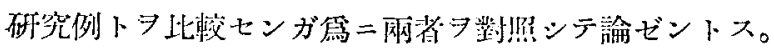

\section{(3) 䂰究例ノ組織學的所見卜文獻トノ對照二就テ}

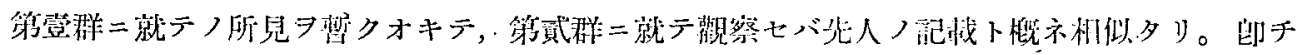

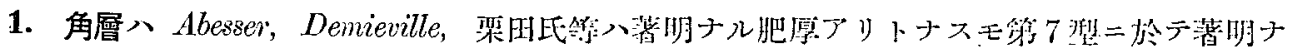

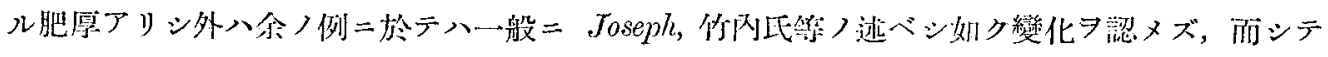

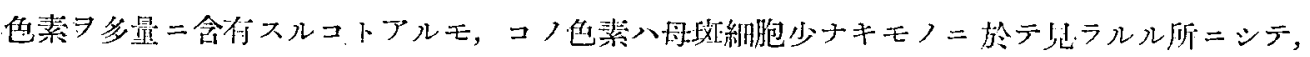

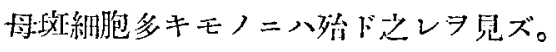

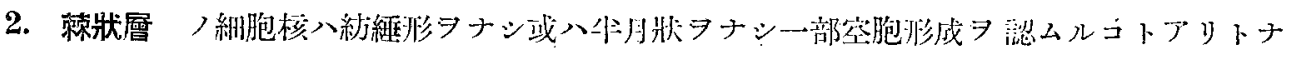

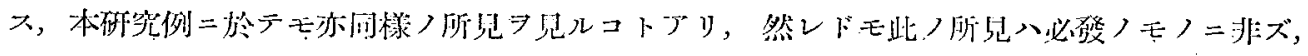
又色素含量モ不㘳ナリ。

3. 基底層 Joseph, Virchow ノ如ク火ナル變化ナシトナスモノアルモ； Hesser，Dalla-Fa-

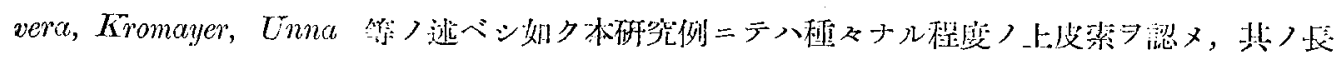

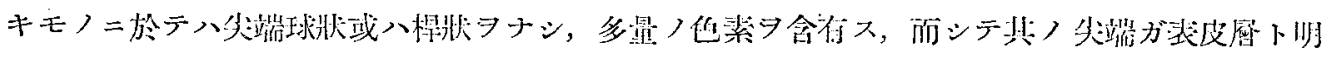

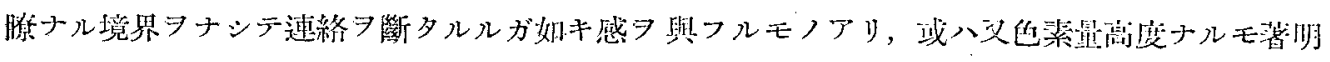

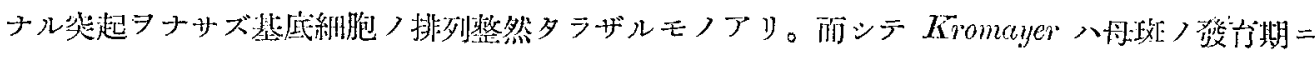

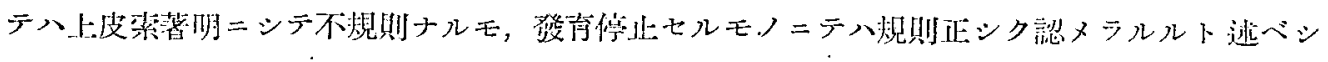

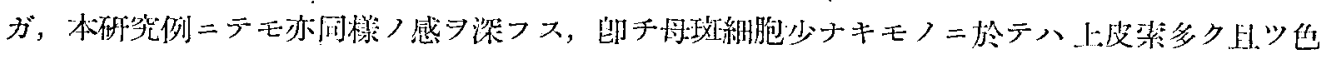

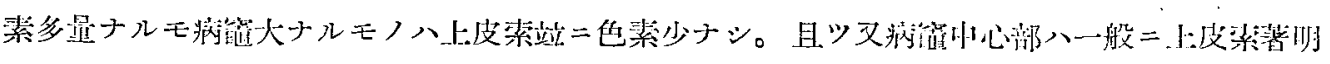

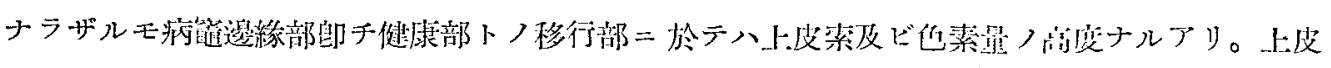

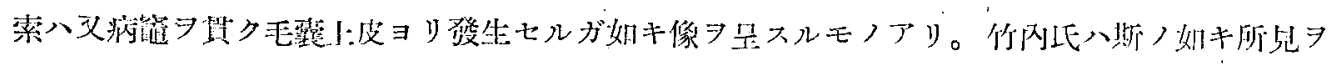

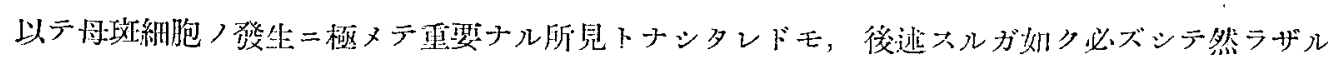
モノアリ。

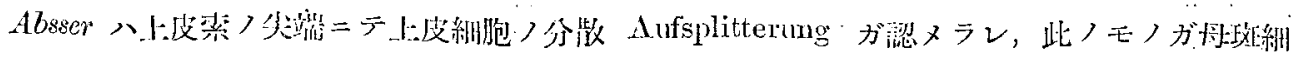

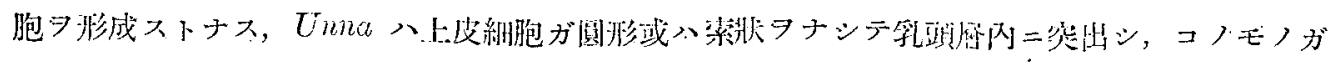

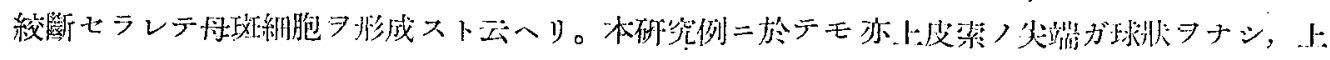




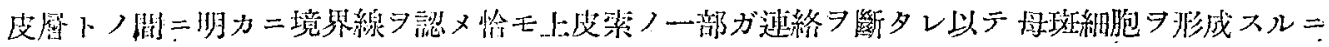

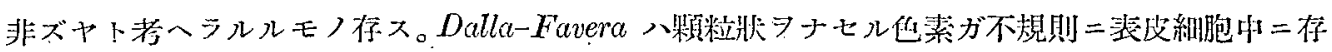

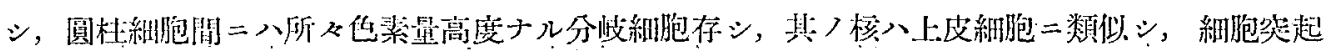

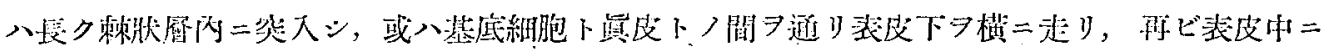

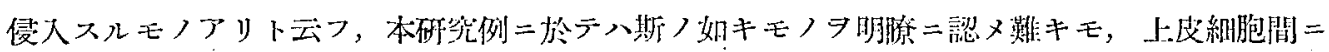

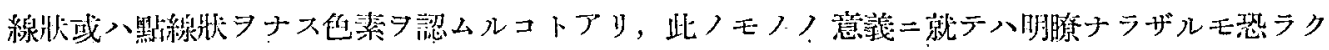

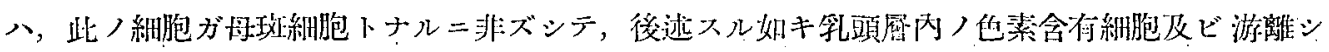

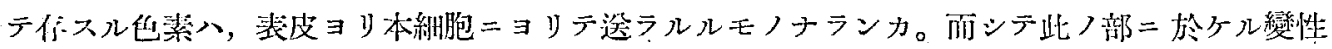

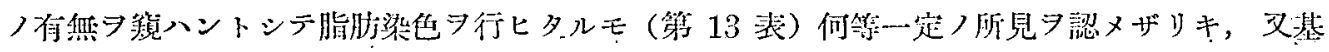

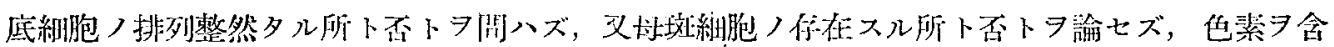

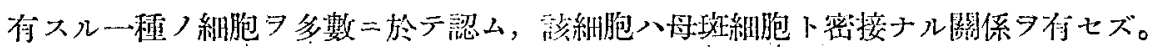

4. 乳頭層 Bauer 八表皮直下二瀻維性ノ結締織つリ，コノモノフ Randbindegewebe 卜程

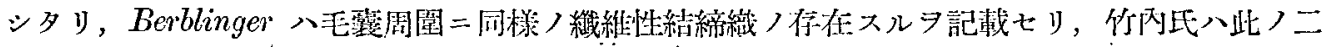

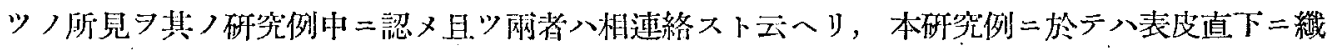
維性結縍織

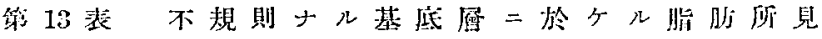

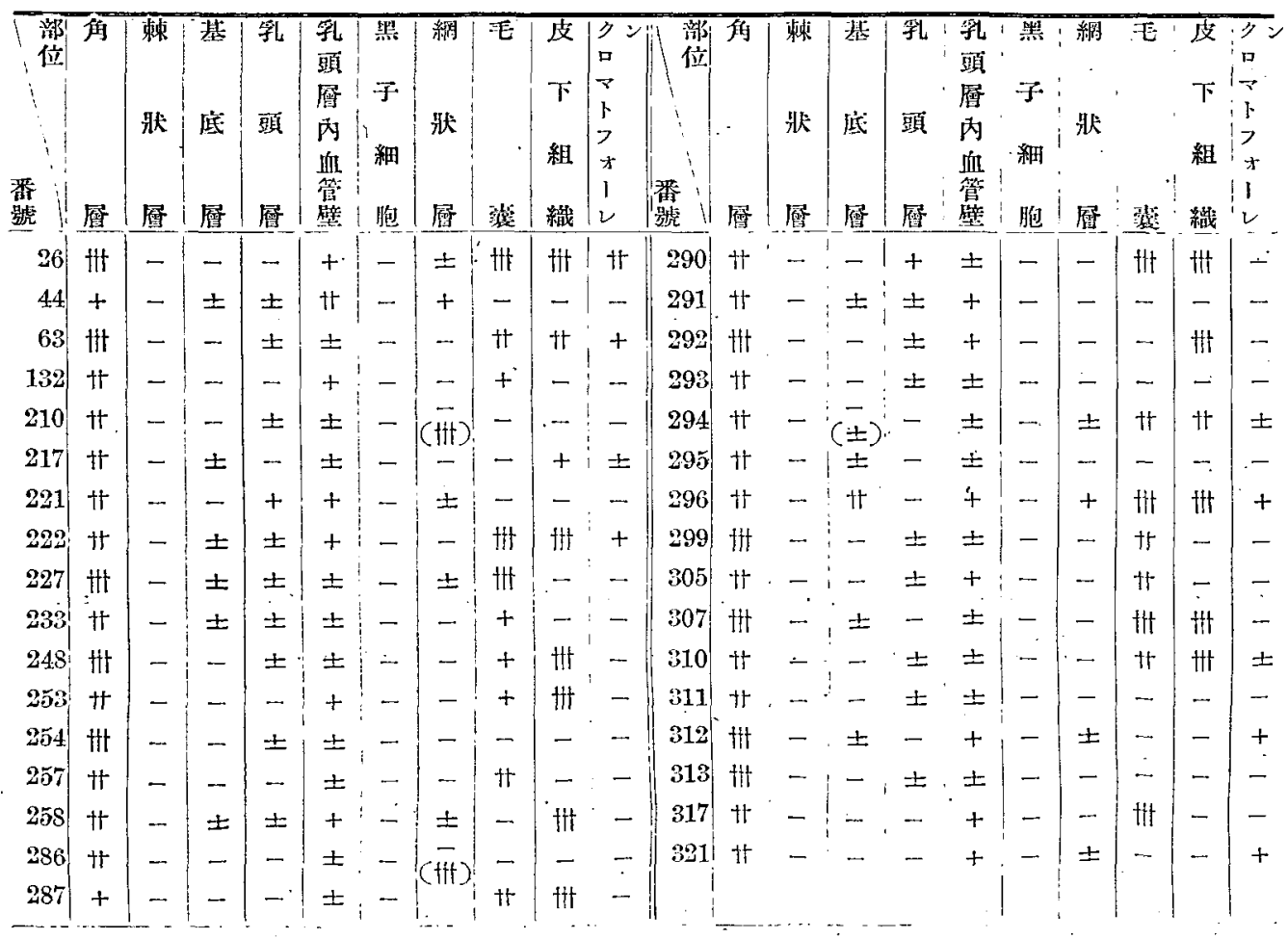




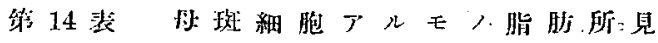

\begin{tabular}{|c|c|c|c|c|c|c|c|c|c|c|c|c|c|c|c|c|c|c|c|c|c|}
\hline 1 & 層 & 層 & 底 & 啳 & 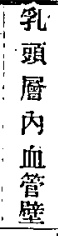 & $\begin{array}{l}\text { 子 } \\
\text { 子 } \\
\text { 細 } \\
\text { 胞 }\end{array}$ & 狀 & 王趡 & $\begin{array}{l}\text { 皮 } \\
\text { 下 } \\
\text { 組 } \\
\text { 䋊 }\end{array}$ & $\begin{array}{l}73 \\
\square \\
7 \\
1 \\
7 \\
\pi \\
1 \\
2\end{array}$ & 番 & 臂 & 狀 & 管 & 孚 & 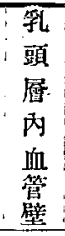 & $\begin{array}{l}\text { 照 } \\
\text { 子 } \\
\text { 勫 }\end{array}$ & 是 & 雚 & $\begin{array}{c}\text { 皮 } \\
\text { 下 } \\
\text { 組 }\end{array}$ & $\begin{array}{l}3 \\
0 \\
7 \\
5 \\
7 \\
y \\
1 \\
2 \\
2\end{array}$ \\
\hline 334 & tt & - & - & - & \pm & - & - & - & - & \pm & 408 & tt & - & -1 & - & + & - & - & -1 & $-!$ & - \\
\hline 336 & & - & - & - & \pm & - & + & $\pi$ & 洲 & - & 405 & $t$ & - & $(\overline{( \pm)}$ & - & - & - & + & $t t$ & & - \\
\hline $337 \mid$ & tt & $(\overline{+})$ & - & - & - & - & - & + & - & - & 406 & $t$ & - & -1 & - & \pm & - & - & - & - & \pm \\
\hline 839 & t. & - & $( \pm)$ & - & - & - & + & 计 & - & $\dot{-}$ & 408 & tt & - & - & $\cdots$ & + & - & - & $H^{\circ}$ & - & - \\
\hline $3 \pm 0$ & tt & - & - & - & \pm & - & - & - & - & - & 409 & tr & - & - & - & \pm & - & - & - & - & - \\
\hline 348 & tt & - & - & - & - & - & - & - & - & - & $413^{\prime}$ & tt & - & - & - & - & - & - & - & - & - \\
\hline 358 & $\mathrm{ftt}$ & - & - & - & \pm & $\dot{-}$ & - & - & - & - & 414 & $\mathrm{HH}$ & - & - & - & \pm & - & - & \pm & - & - \\
\hline 307 & + & -- & \pm & - & \pm & - & - & - & - & \pm & 416 & $t+$ & - & - & - & \pm & - & - & + & - & + \\
\hline 361 & tt & - & - & - & \pm & - & - & tt & - & \pm & 417 & H & - & \pm & - & \pm & \pm & \pm & $\mathrm{ttt}$ & - & + \\
\hline 362 & tit & - & - & - & \pm & \pm & \pm & \# & - & -- & 4.18 & $\mathrm{tH}$ & - & \pm & - & + & + & - & tif & - & + \\
\hline 363 & ttt & - & - & - & - & - & - & + & - & + & 419 & tt & - & - & - & + & - & - & - & - & + \\
\hline 366 & t & - & - & - & \pm & -1 & \pm & $\mathrm{Htt}$ & - & - & 420 & $\div$ & - & - & - & - & - & - & - & - & - \\
\hline 371 & $t+$ & - & - & - & - & \pm & - & + & - & + & 421 & tt & - & - & - & 士 & $\overline{( \pm)}$ & - & $\mathrm{ttt}$ & - & - \\
\hline $378^{\prime}$ & $t$ & - & - & - & + & - & - & - & - & - & 423 & tt & - & \pm & - & \pm & \pm & $\ldots$ & + & & \pm \\
\hline 874 & $\mathrm{Htt}$ & - & - & - & \pm & - & 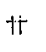 & $\mathrm{ftt}$ & - & - & 425 & tt & - & $\therefore$ & - & \pm & \pm & - & - & - & - \\
\hline 375 & tt & 7 & - & - & \pm & - & - & + & - & - & 426 & tit & - & - & - & \pm & -1 & - & $\mathrm{Ht}$ & - & - \\
\hline 376 & + & - & $\dot{-}$ & - & + & - & - & - & - & - & 428 & tt & $\therefore$ & - & - & - & - & \pm & H & $=$ & - \\
\hline $381 !$ & tt & - & - & - & + & - & - & - & - & - & 4.29 & Ht & - & - & - & $\therefore$ & - & - & - & - & \pm \\
\hline $88 a_{i}$ & it & - & $\because$ & - & \pm & \pm & - & + & - & + & 431 & + & - & - & - & + & - & $\ldots$ & - & - & - \\
\hline . & + & - & - & - & + & - & - & - & - & + & 484 & tt & - & - & $\because$ & - & - & - & - & - & - \\
\hline 387 & & - & - & - & + & - & - & - & - & + & 439 & $\mathrm{Htt}$ & - & - & - & tr & - & - & - & & t \\
\hline 888 & & - & & - & \pm & \pm & - & + & - & - & 440 & tt & $\tau$ & \pm & \pm & + & + & \pm & + & - & - \\
\hline & + & - & & - & - & - & - & $t$ & - & - & 441 & + & - & - & - & \pm & - & - & - & - & + \\
\hline 396 & it & - & & 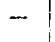 & - & - & - & $t$ & $\therefore$ & - & 448 & tt & - & - & - & + & - & - & + & - & - \\
\hline 98 & th & $-?$ & $(+)$ & - & + & - & - & - & - & \pm & 444 & $t$ & - & - & $\therefore$ & + & $\div$ & - & - & $\therefore$ & - \\
\hline 402 & † & & & & \pm & -1 & - & -1 & & 1 & 446 & it & - & - & - & - & - & $t$ & tt & - & - \\
\hline
\end{tabular}

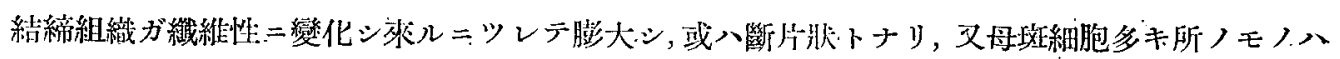

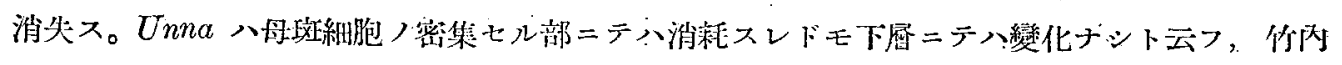

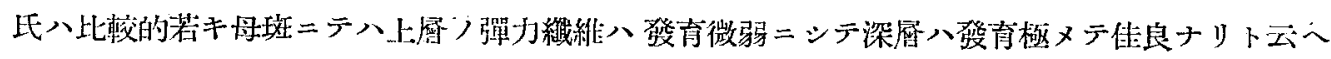

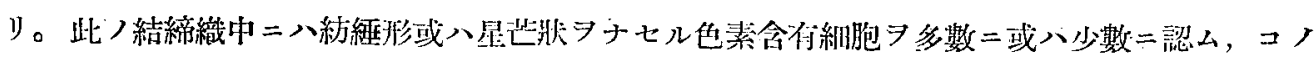
モノ

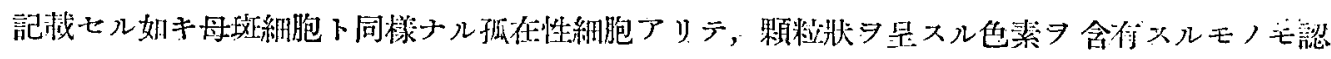

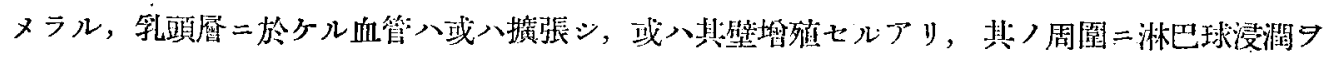

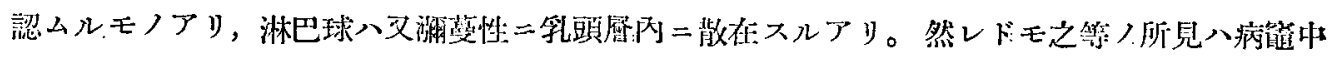

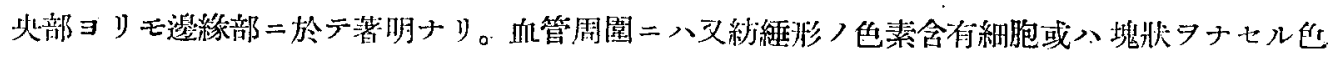




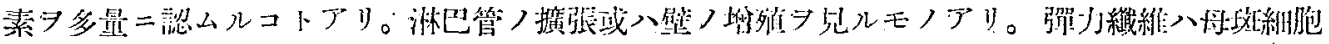

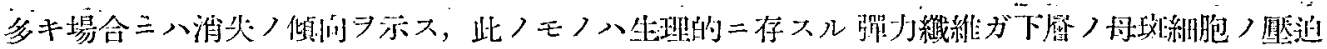

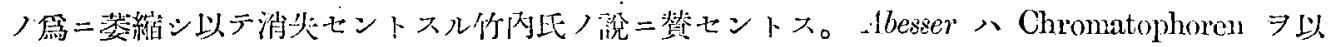

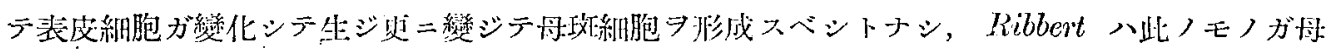

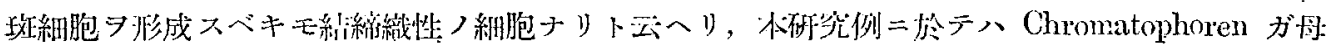

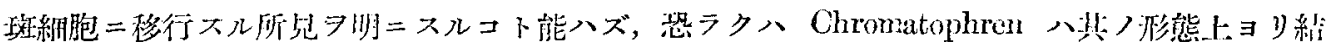

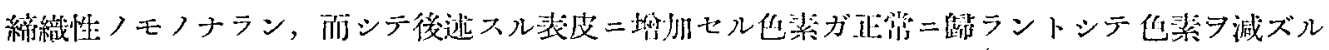

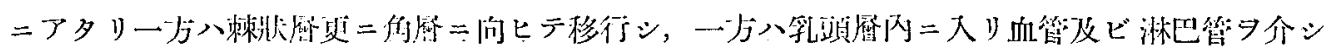

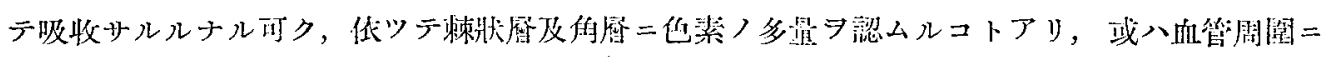

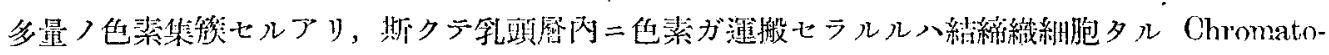

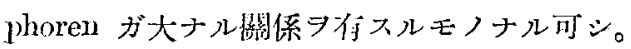

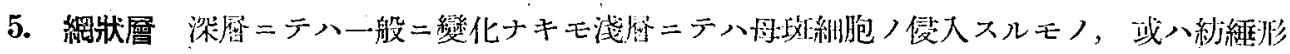

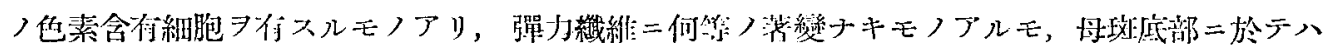

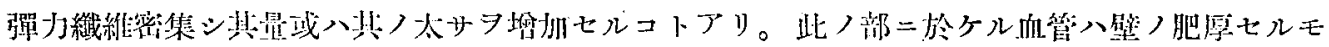
ノアルモ其他一般三藷明ナル變化フ認メズ。

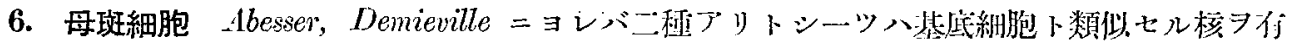

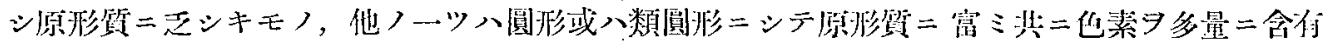

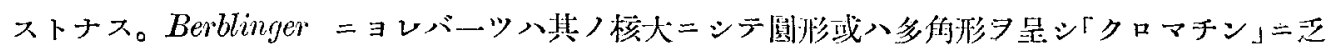

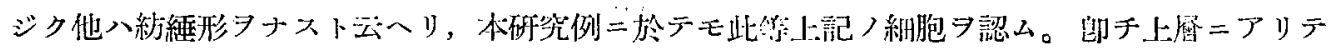

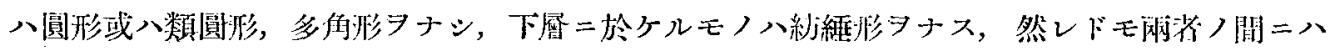

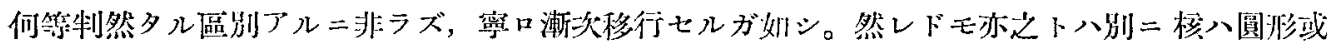

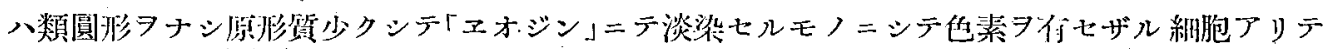

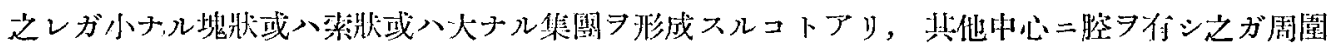

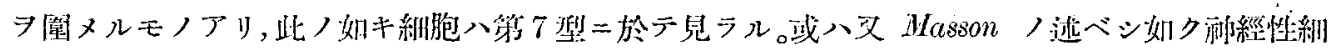

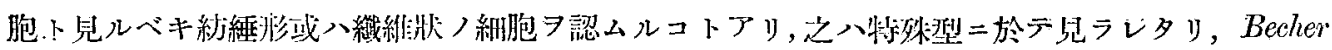
モ亦上皮性細胞ノ他二滆縒性絧胞ノ存スル

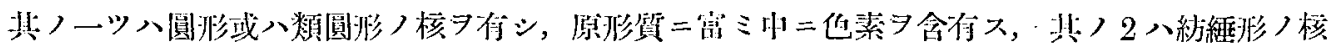

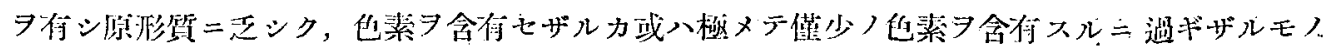

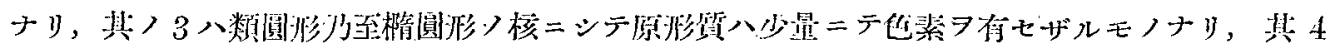

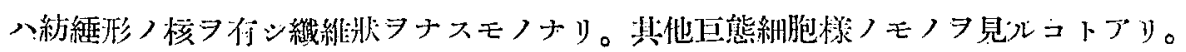

\section{(4) 母斑ノ組織翼的構造竝ビニ母斑/發生二就テ}

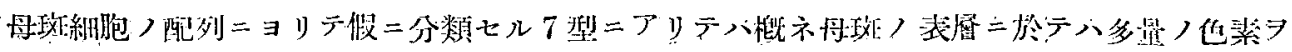

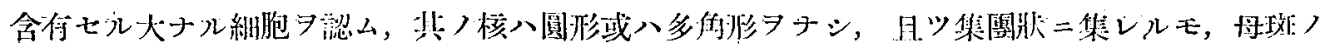




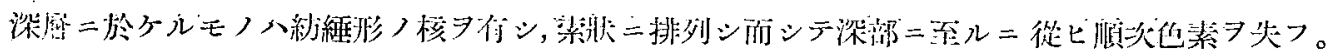

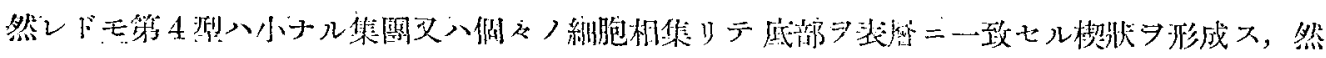

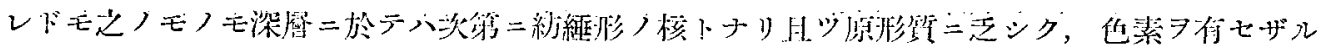

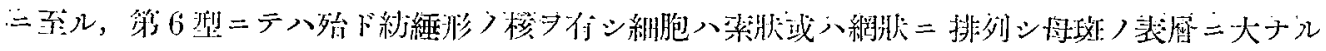

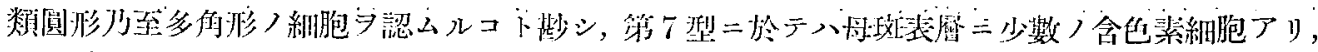

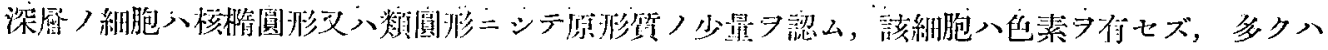

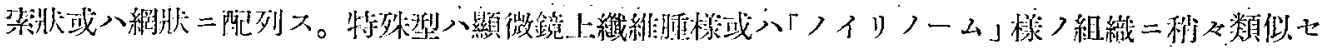

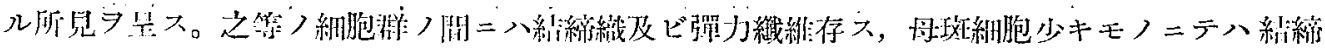

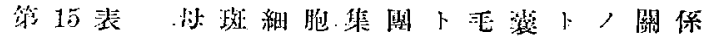

\begin{tabular}{|c|c|c|c|c|c|c|c|c|c|c|c|c|c|c|}
\hline 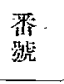 & 霖 & $\begin{array}{l}\text { 關. } \\
\text { 係 }\end{array}$ & $\begin{array}{l}\text { 番 } \\
\text { 跆 }\end{array}$ & $\begin{array}{l}E \\
\text { 政 }\end{array}$ & $\begin{array}{l}\text { 閔 } \\
\text { 的 }\end{array}$ & $\begin{array}{l}\text { 䨳 } \\
\end{array}$ & 琵 & $\begin{array}{l}\text { 關 } \\
\text { 係 }\end{array}$ & 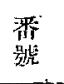 & $\begin{array}{l}\text { 昰 } \\
\text { 瀿 }\end{array}$ & $\begin{array}{l}\text { 闆 } \\
\text { 倸 }\end{array}$ & $\begin{array}{l}\text { 番 } \\
\text { 踢 }\end{array}$ & 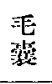 & $\begin{array}{l}\text { 關 } \\
\text { 保 }\end{array}$ \\
\hline 325 & - & - & $357 !$ & + & 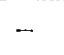 & 386 & + & - & 4.15 & + & - & 444 & + & - \\
\hline 829 & - & - & 358 & - & - & 387 & + & - & 4.16 & - & - & 44.5 & - & - \\
\hline 830 & + & - & 859 & - & - & 388 & + & - & 417 & - & $\therefore$ & 446 & - & - \\
\hline 331 & + & - & 360 & - & $\because$ & 389 & + & - & 418 & - & - & & & \\
\hline 982 & + & - & 361 & - & - & 890 & + & - & 419 & - & $\therefore$ & & & \\
\hline 833 & + & \pm & 362 & $\rightarrow$ & - & 391 & + & \pm & 480 & - & - & & & \\
\hline $384:$ & + & - & 863 & + & - & 392 & + & - & $4: 21$ & - & - & & & \\
\hline $385^{\circ}$ & + & - & 364 & + & - & 393 & + & $\therefore$ & $4: 22$ & - & - & & & \\
\hline 886 & + & + & 365 & + & - & 394 & + & - & 4.23 & $\therefore$ & - & & & \\
\hline 837 & + & + & 366 & + & + & 395 & + & \pm & 424 & - & - & & & \\
\hline 398 & + & \pm & 367 & + & - & 396 & + & + & 4.25 & + & - & & & \\
\hline :39 & + & + & 368 & + & - & 397 & + & \pm & 426 & - & - & & & \\
\hline$\$ 4: 0$ & + & + & $36 \dot{9}$ & + & - & 398 & + & - & 427 & + & - & & & \\
\hline 34.1 & - & - & 370 & - & - & .899 & + & - & 4.28 & - & - & & & \\
\hline 842 & + & \pm & 371 & + & - & 4.00 & + & - & $4.2 \dot{9}$ & - & - & & & \\
\hline $34 \%$ & - & - & 372 & - & - & 401 & - & - & 430 & - & - & & & \\
\hline 344 & + & - & 373 & - & - & 402 & $\ldots$ & - & 481 & - & - & & & \\
\hline 845 & - & - & 374 & + & \pm & 403 & + & - & 432 & - & - & & & \\
\hline$\$ 46$ & + & - & 875 & + & - & 404 & + & - & 433 & - & - & & & \\
\hline 347 & - & - & 876 & + & - & 4.05 & + & \pm & $434^{\circ}$ &.- & - & & . & \\
\hline 848 &. & - & 377 & + & - & 406 & + & - & 435 & - & - & & . & \\
\hline 849 & - & - & 378 & + & \pm & 407 & + & - & 486 & + & - & & & \\
\hline 850 & - & - & 379 & - & - & 408 & - & - & $4: 37$ & - & - & & 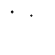 & $\because$ \\
\hline 351 & - & $\ldots$ & 380 & + & - & 409 & + & - & 438 & + & - & & & \\
\hline 852 & + & - & 381 & + & $\pm:$ & 410 & + & - & 489 & + & - . & & $\cdots$ & \\
\hline 853 & - & - & 382 & + & - & 411 & + & - & 440 & + & - & & & \\
\hline 854 & + & - & 383 & + & - & 412 & $\therefore$ & $\therefore$ & 441 & - & - & & & $\cdots$ \\
\hline 355 & - & - & 384 & + & - & 413 & + & \pm & 4.42 & + & - & & 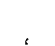 & $\therefore$ \\
\hline 856 & - & - & 385 & + & - & 4.14 & + & - & 443 & - & - & & ' & \\
\hline
\end{tabular}




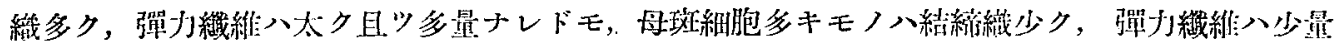

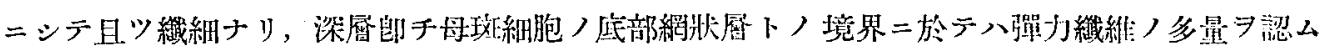

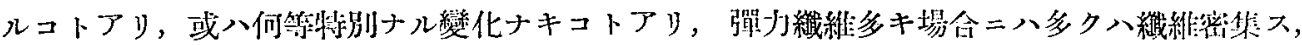

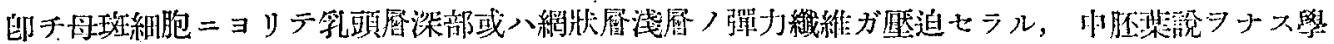

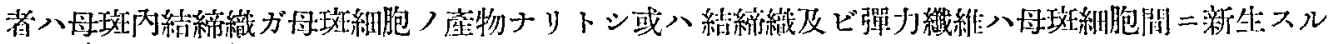

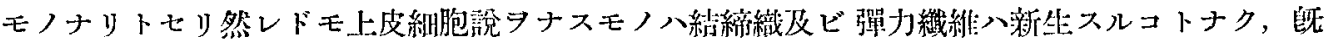

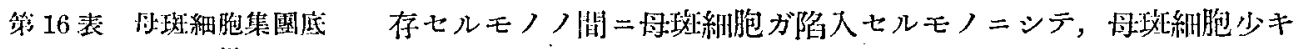

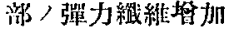

\begin{tabular}{|c|c|c|c|}
\hline 型 & 例数 & 智加数 & $\%$ \\
\hline 第一型 & $30^{\circ}$ & 7 & 23.3 \\
\hline ，攺二型 & 25 & .7 & 28.0 \\
\hline 第三型 & 32 & 17 & 53.1 \\
\hline 第四型 & 12 & 4 & 38.3 \\
\hline 第五型 & 9 & 3 & 33.3 \\
\hline 第六型 & 4 & 2 & 50.0 \\
\hline 第七型 & 5 & 2 & 40.0 \\
\hline 特姝型 & 2 & 0 & 0 \\
\hline 计 & 119 & 42 & 35.2 \\
\hline
\end{tabular}

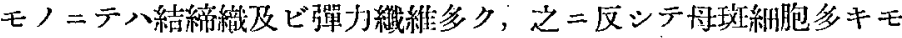

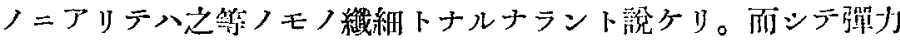

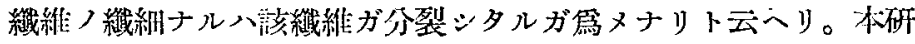

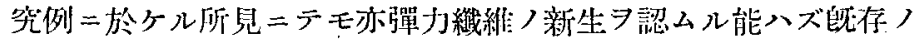
モノノ間二母玟細胞ノ陷入七ルナルガ如シ。母玟ノ底部二於ケル

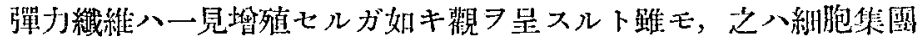

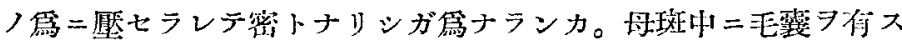
ルコト稀ナラズ，而シテ其ノ上皮ガ表皮トノ移行部二於デ或、媣

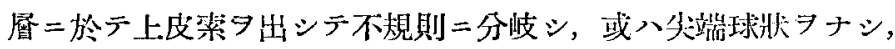

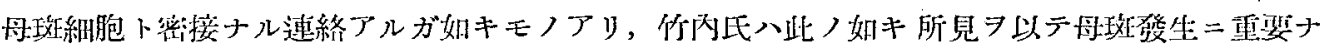

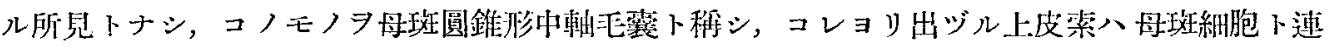

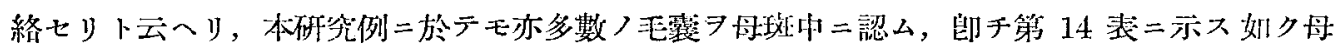

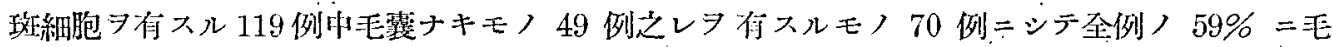
垔ヨ存入， 18 例 $(15 \%)=$ 過ギズ，サレバ竹內氏ノ云フ如キ毛囊上皮ト母玟細胞トノ連絡二就キテハ重キ フ置ク 晸ゼザルガ如シ。

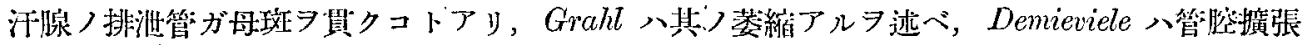

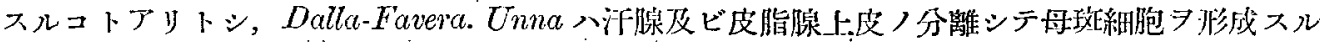

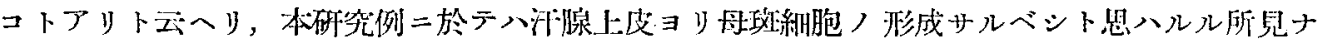

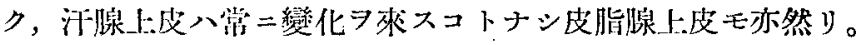

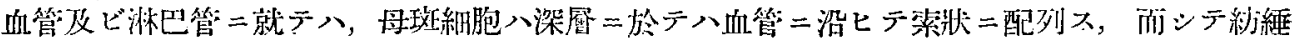

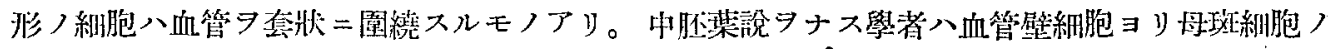

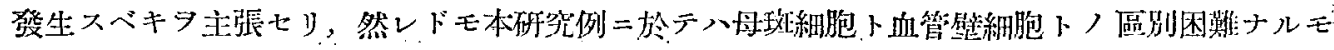

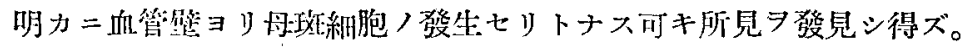

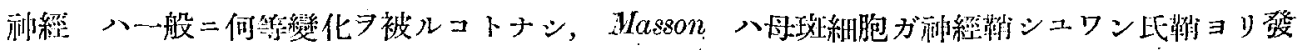

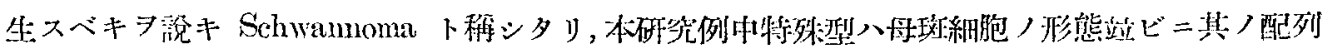




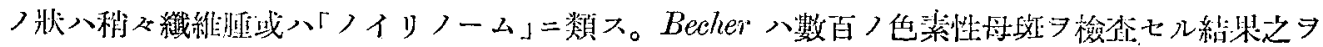

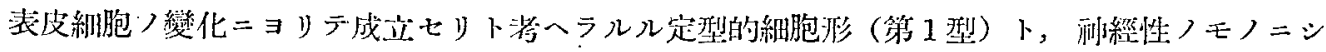

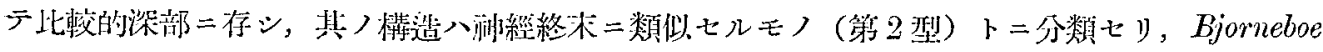

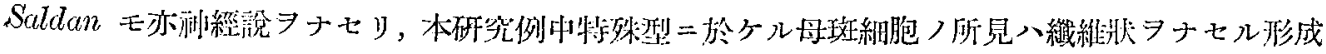

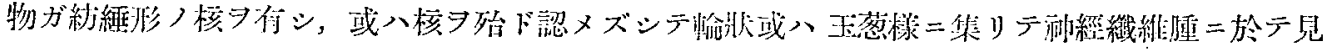

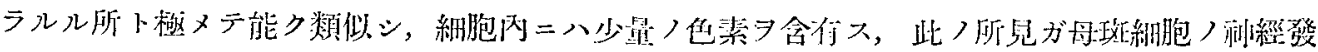

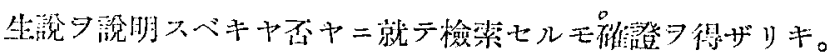

\section{（5）母渂/成立竝二運命二就テ}

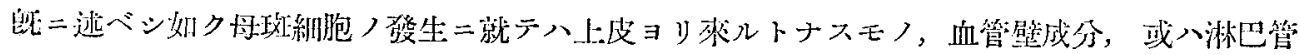

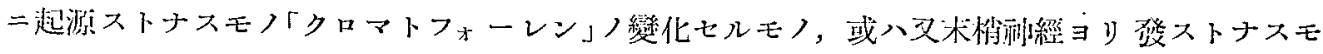

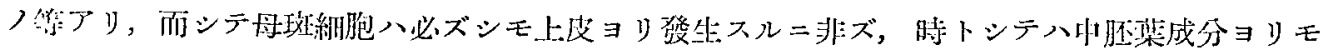

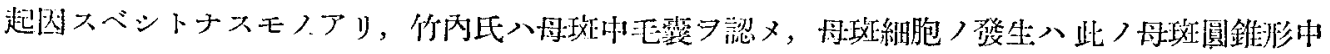

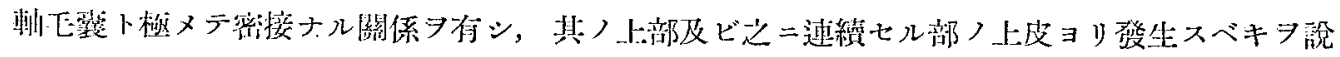

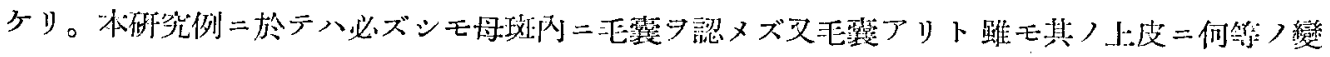

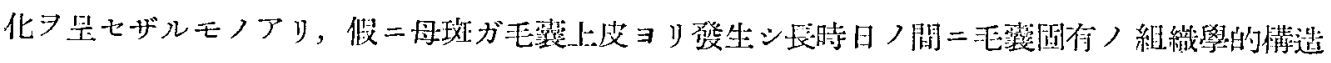

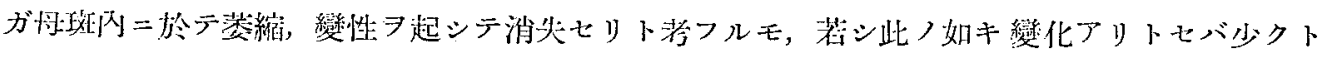

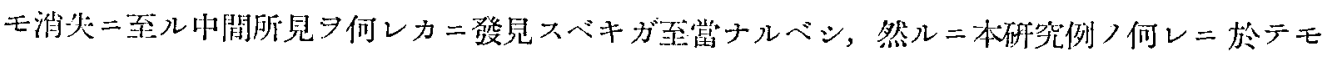

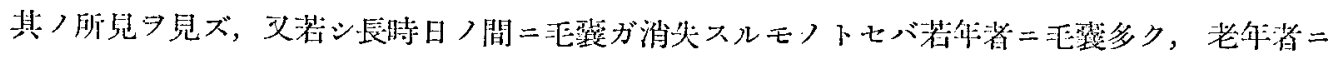

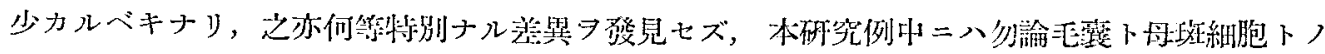

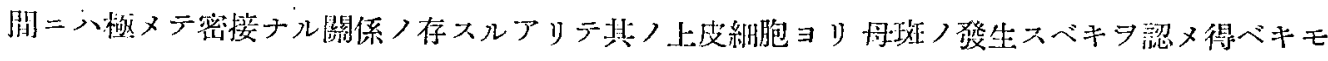
ノアリ，然レドモ之等八少數二過ギズ。

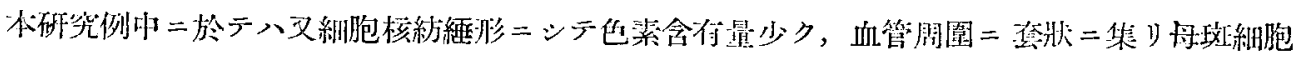
小血唩留成分卜ノ間ノ區别图難ナルモノアリ。

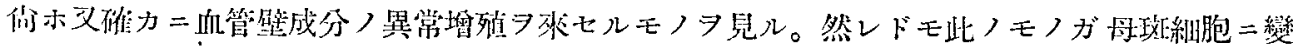

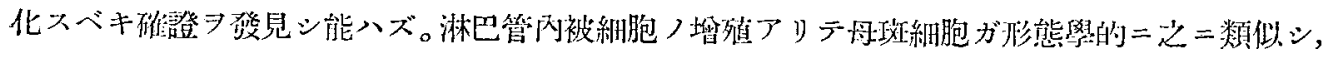

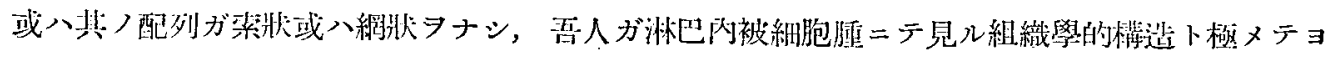

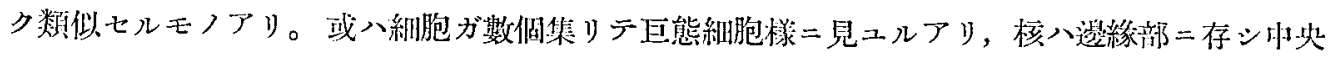

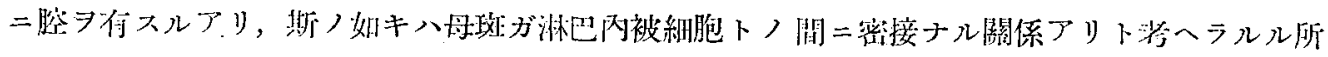
晃ナルガ如シ。

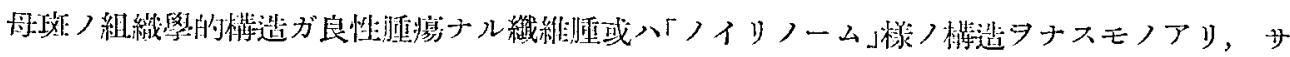

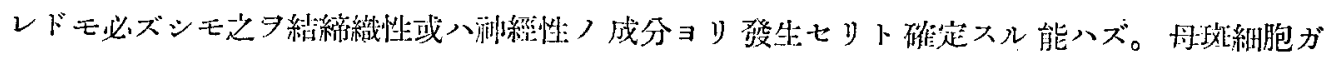
Chromatophoren $ヨ$ リ發生ストナスモ之ガ移行像卜見ルベキモノナシ。

玆二於テ Block, Biesoler 等: $=$ リテ行ハレタル Dioxyphenylalaum = 


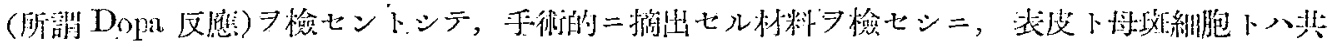

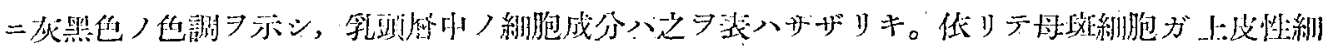

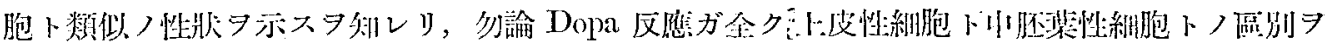

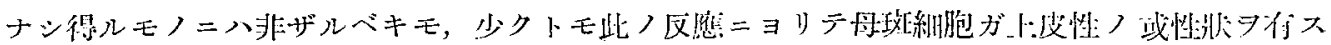
ベキラ想像シ得ベキカ。

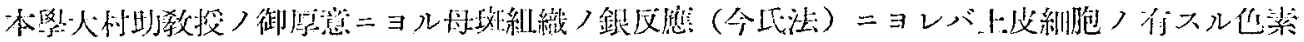

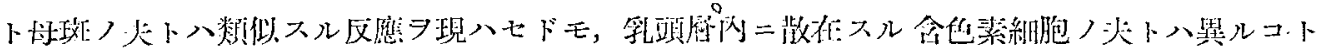
ヨ知レリ。

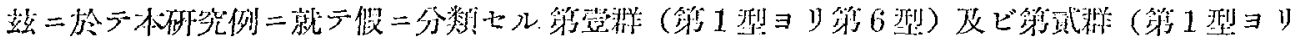

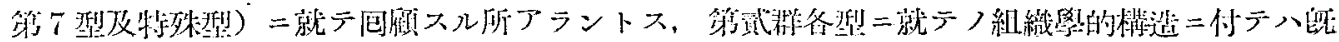

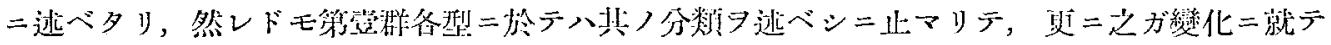

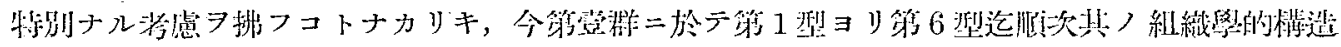

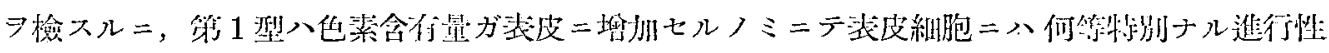

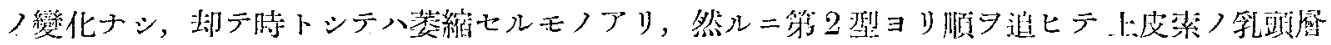

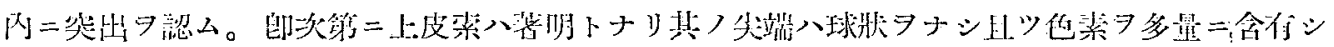

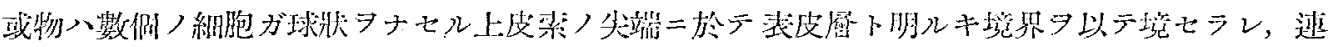

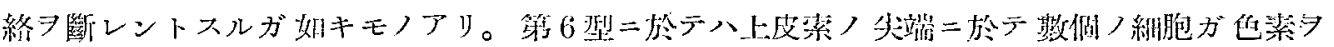

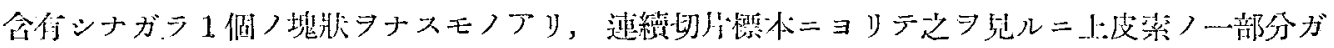

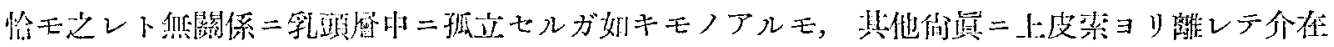

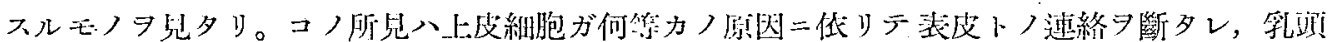

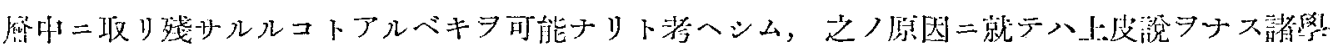

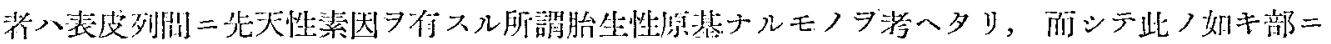

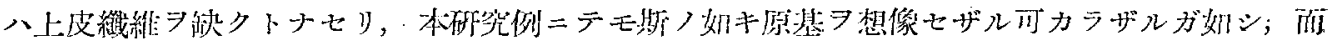

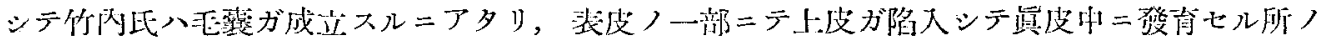

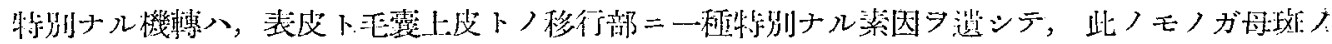

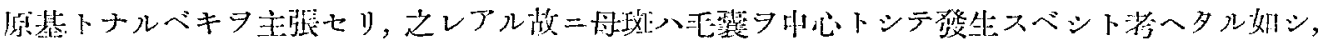

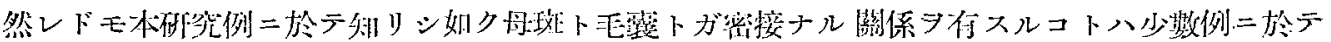

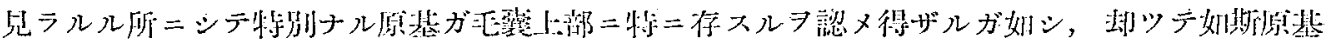

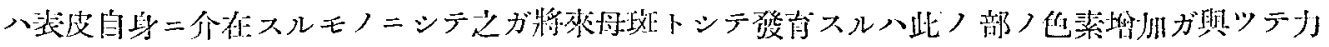

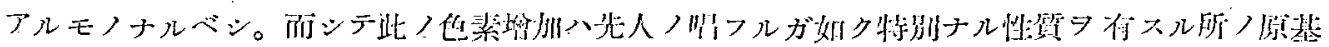

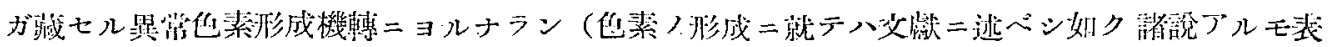

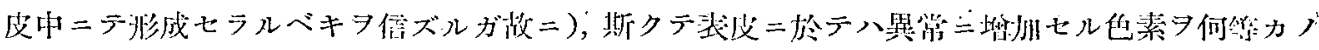

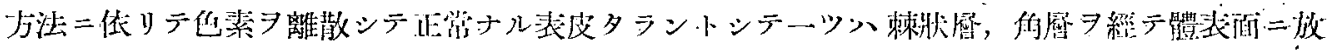




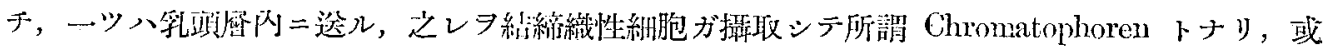

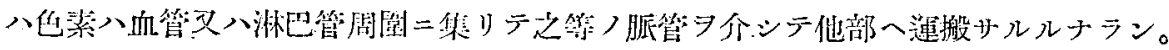

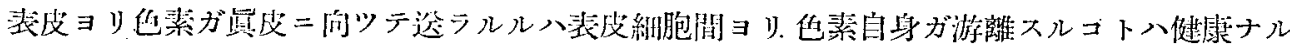

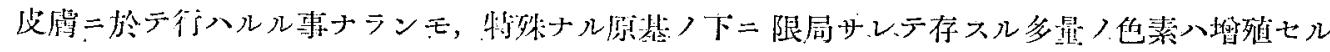

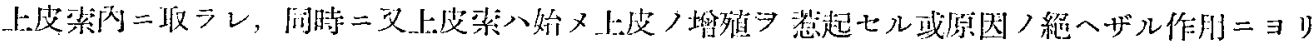

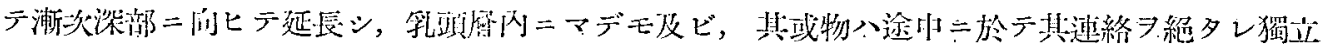

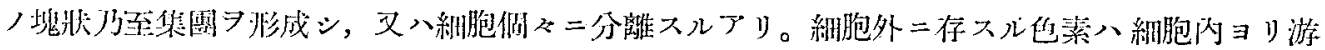

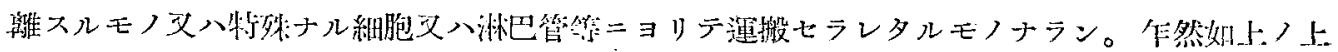

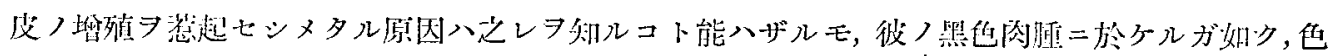

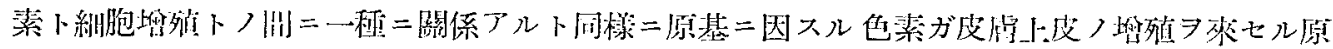
因トモ将へラル闹シ。

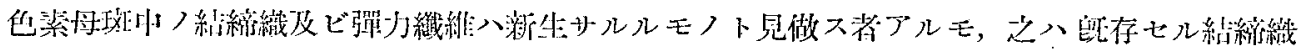

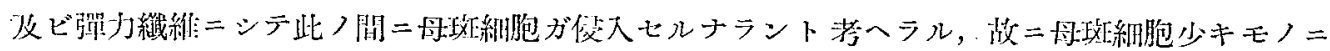

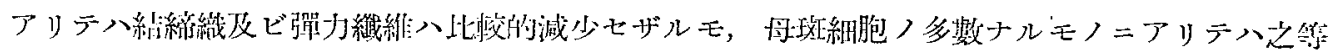

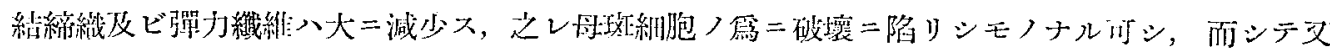

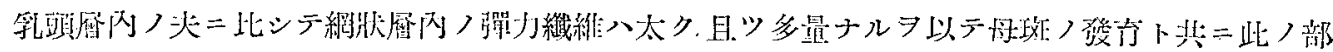

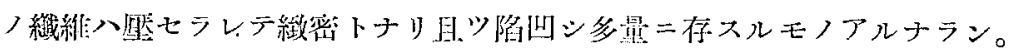

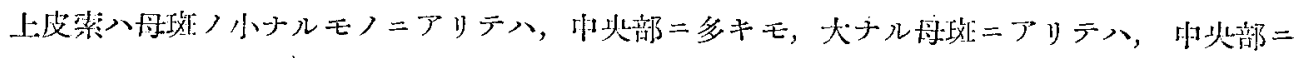

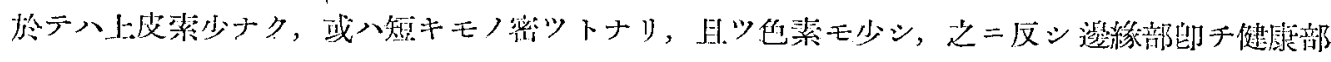

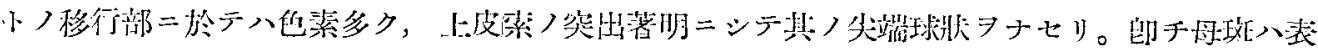

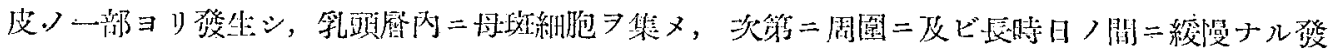

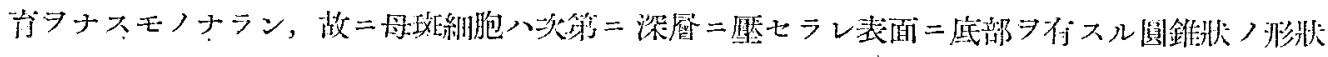

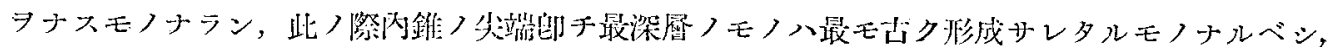

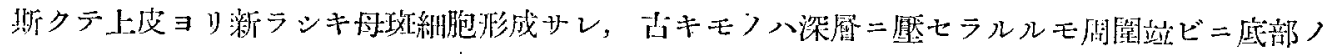

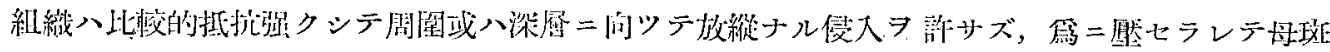

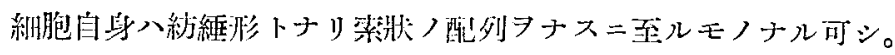

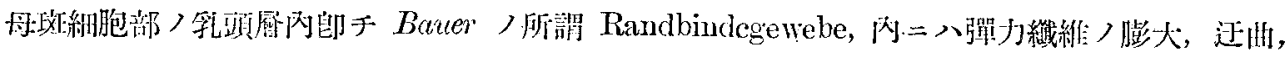

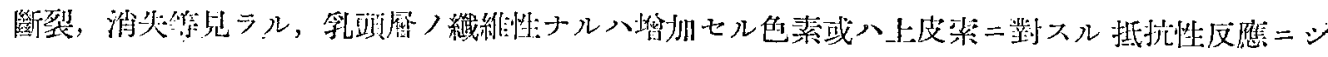

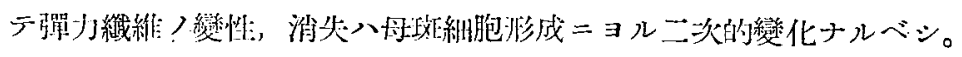

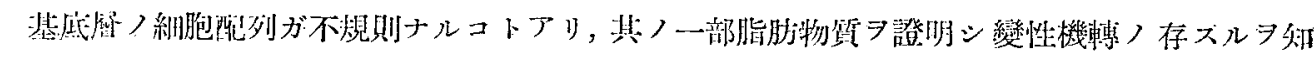

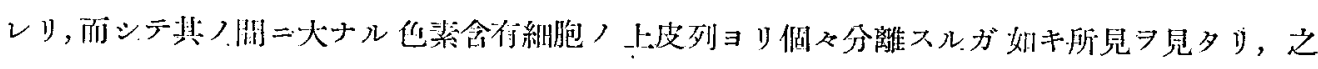

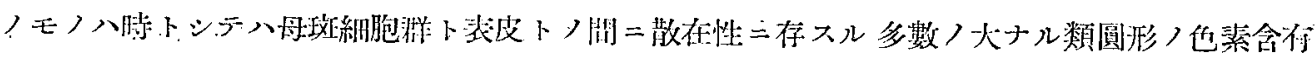

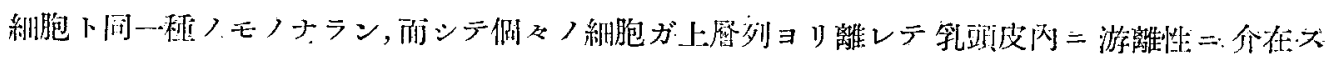




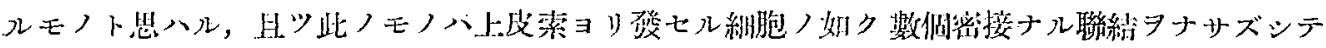

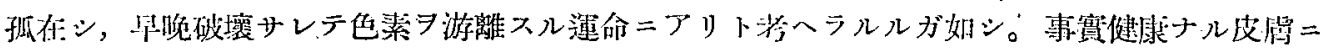
於テモ不規則配列ヨナシ變性機轉ノ存スルハ愿々見ラルル所ニシテ Abesser, Berblinger, Mollen, 竹內氏等モ之ヨ認メ，Abesser ガ.上皮細胞ガ 離斷サレテ母玨細胞习形成ス几所見ナリト解シタ ルモ一般三八認メラレズ。本研究例二於テ符堂群ニ八匭玟細胞ト見ルベキモノ殆ドナシ，此，

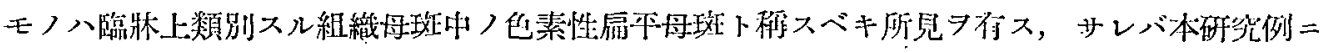

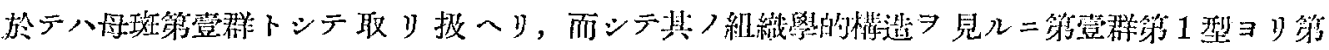

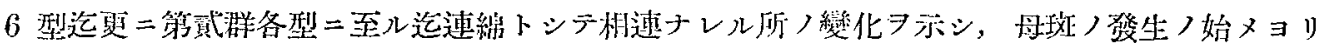
末期二到儿过ノ所見フ想像シ得ル二似タリ。

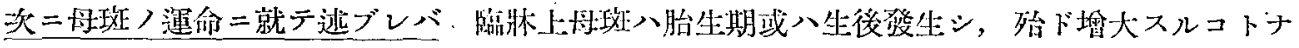

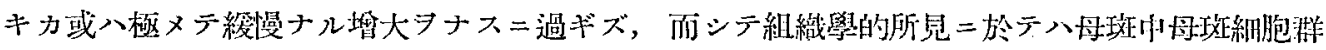
ノ少ナキモノニアリテハー般二母玟細胞八大ナル類圆形ヨ呈ス，而シテ緗胞群多キモノニアリ

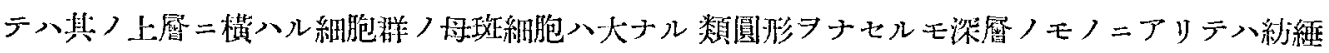

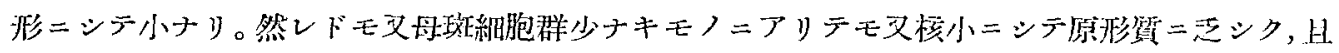

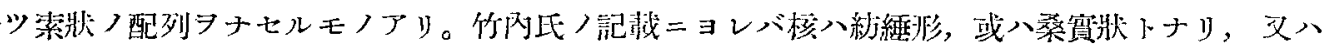

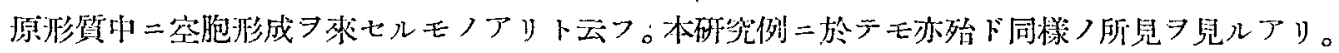

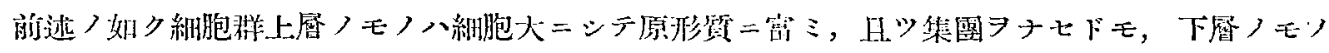

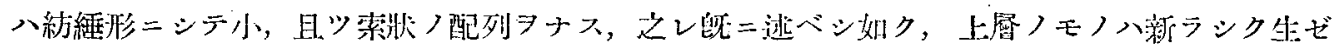

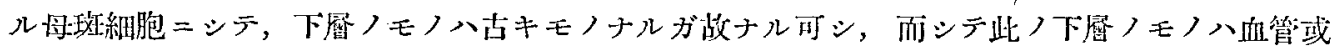

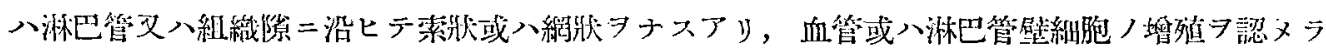

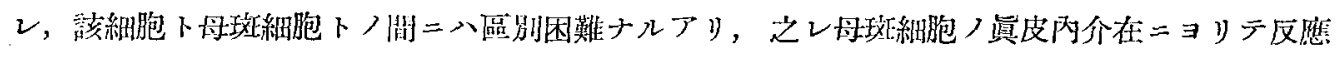

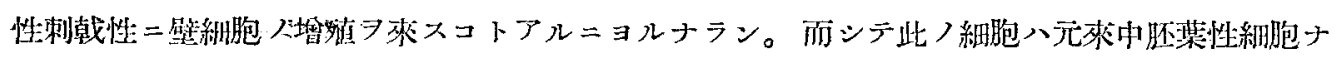

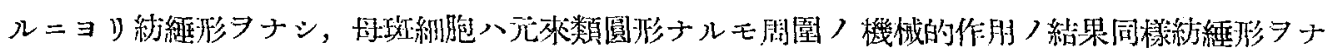

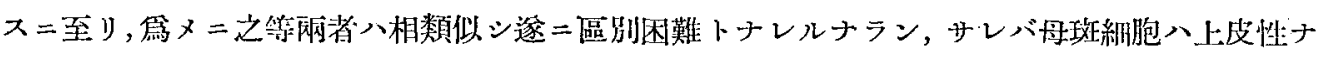

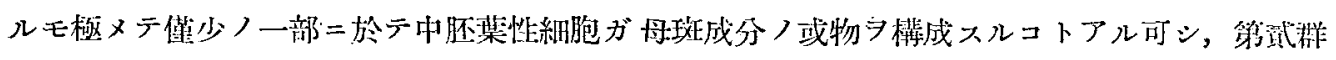

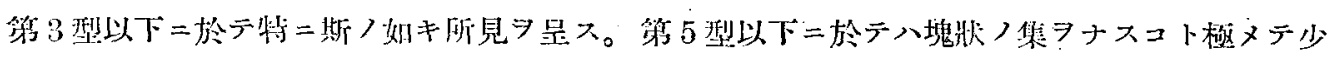

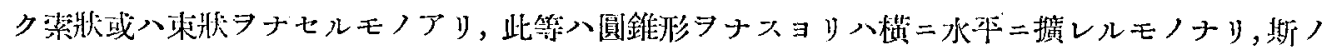

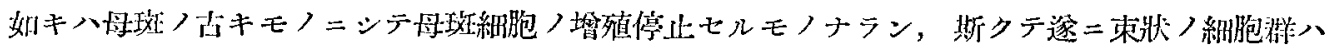

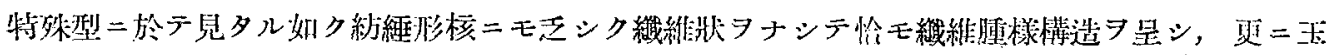

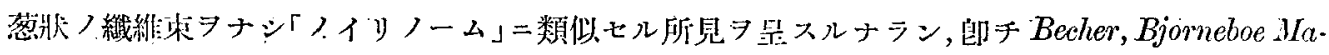

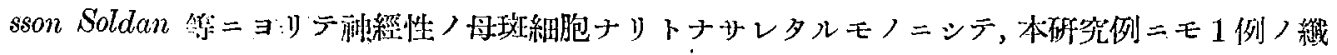

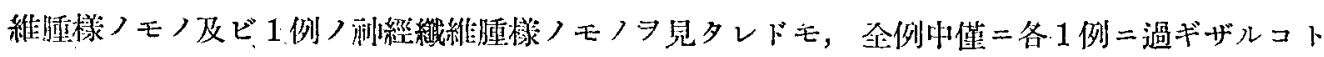

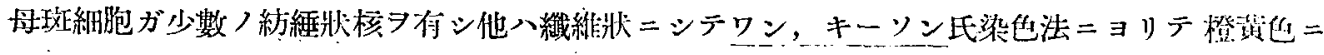




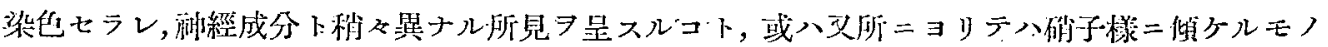

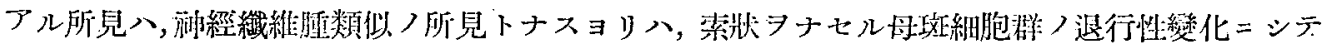

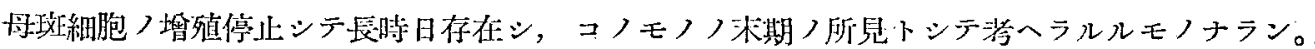

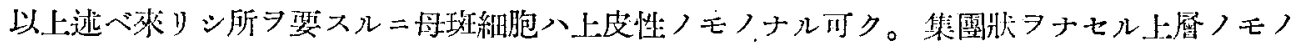

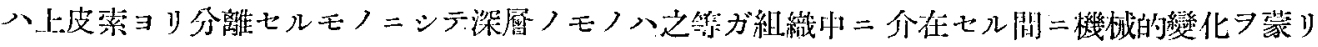

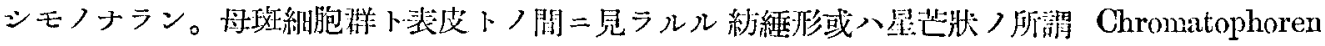

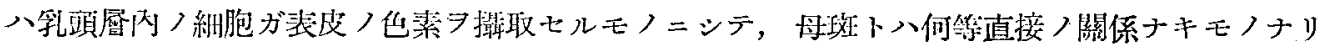

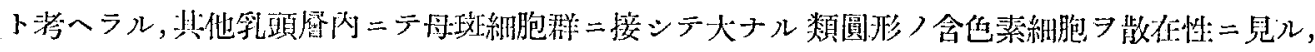

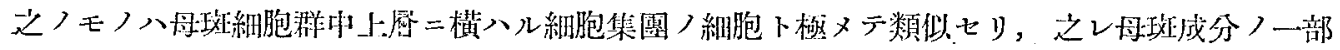

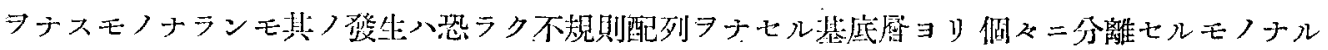

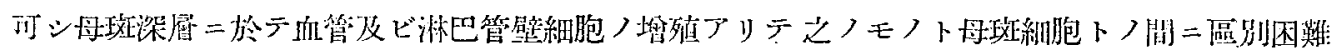

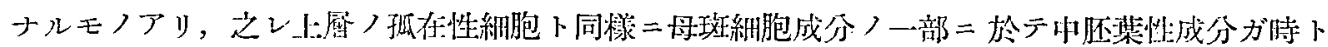

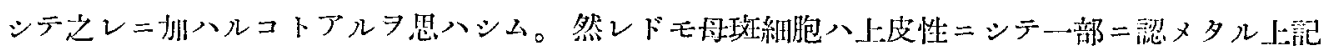

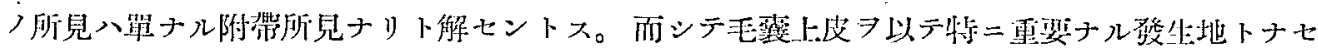
ルモノアルモ必ズシモ然りトナス能ハザルガ如シ。

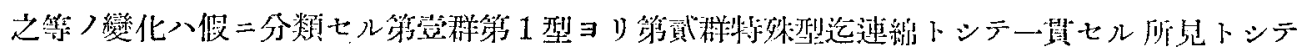
帣へラルルガ如シ。

\section{第 7 章 結 論}

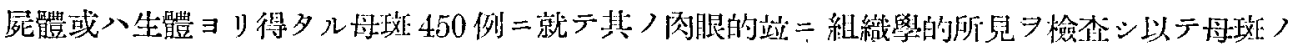
發生站ビ二浑命二就テ次ノ如キ結諭 $尹$ 得タリ。

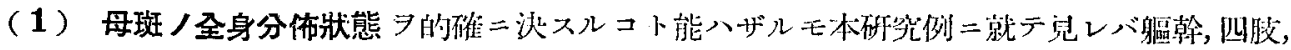

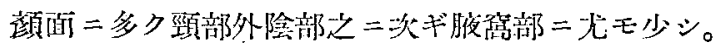

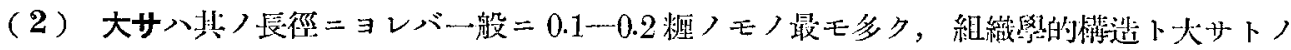
間二八何等特别ナ几關係习認メズ。

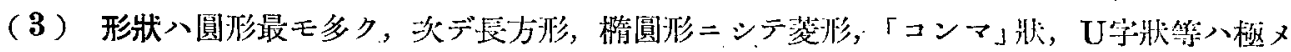

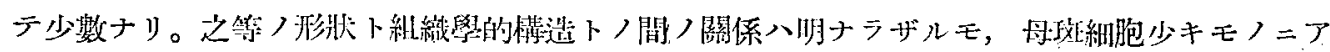

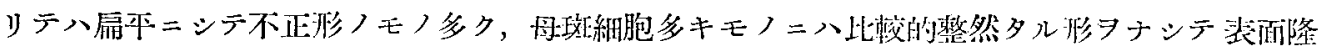
起スル多次。

\section{（4）周園卜!境界八一般二判然夕リ。}

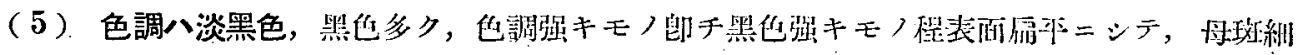

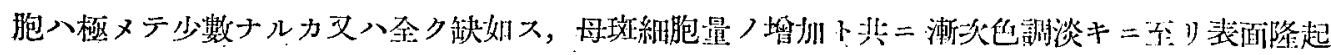

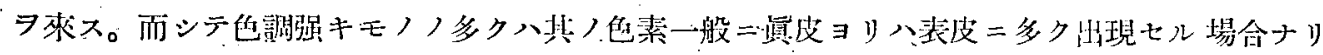
下又。 


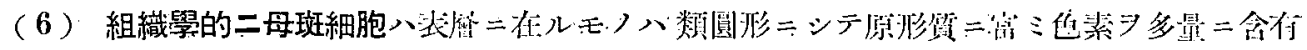

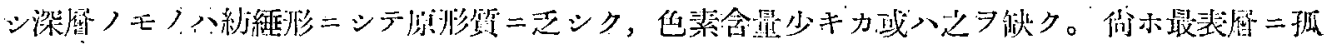

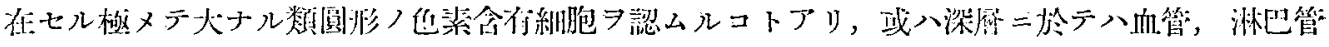

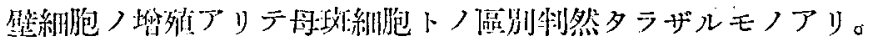

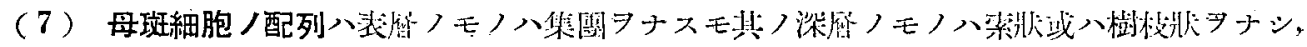

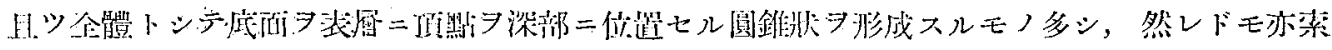

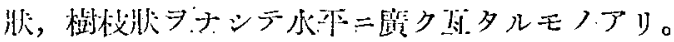

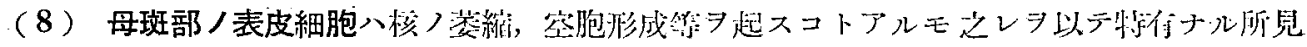

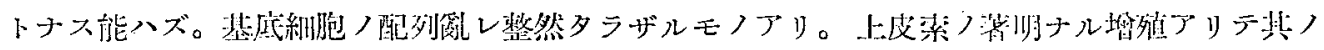

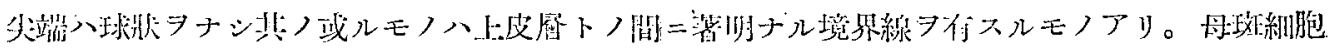

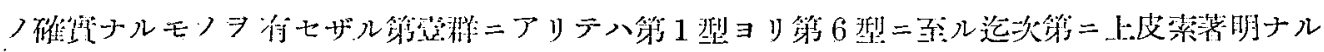

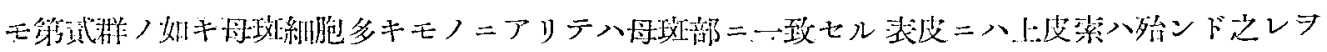

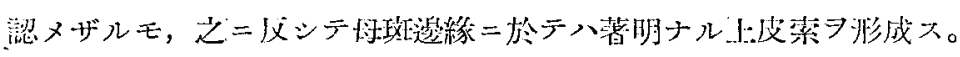

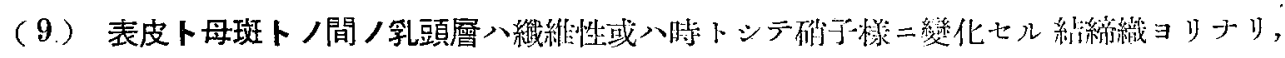

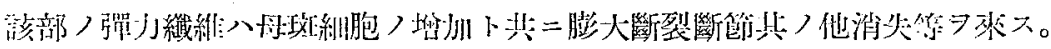

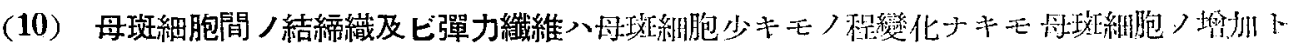

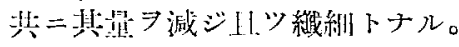

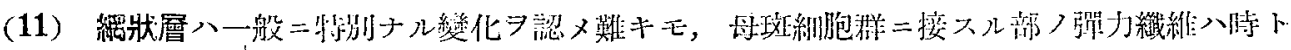

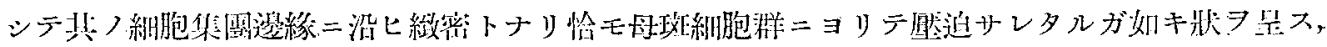

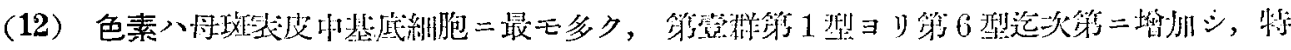

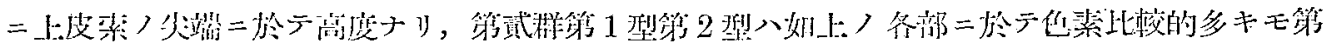

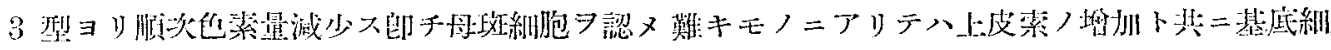

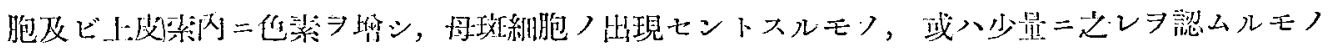

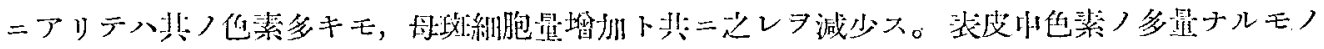

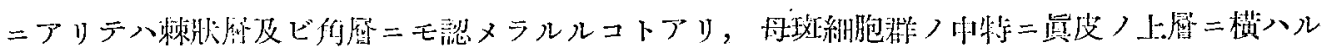

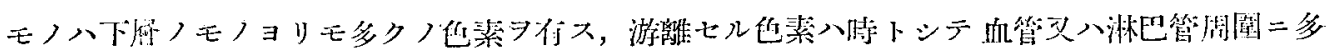
诘二涩メシルルコトアリ。

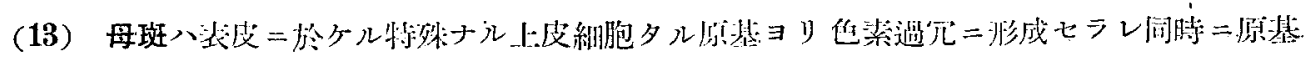

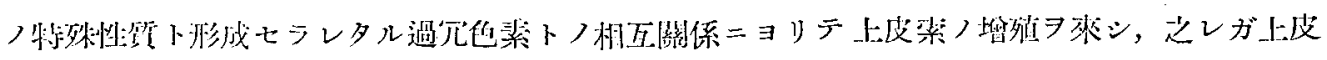

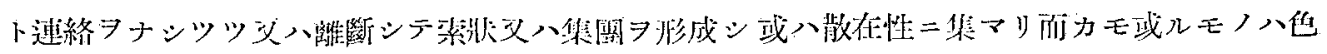

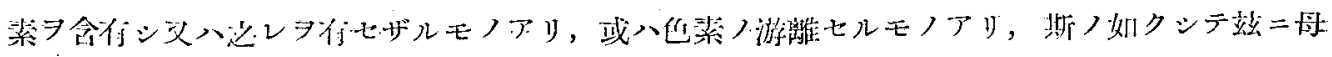

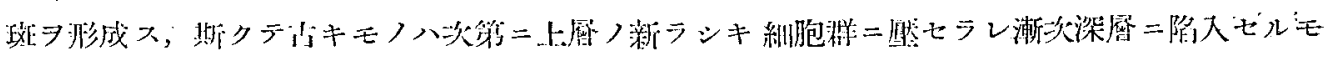
ノナルベシ。 


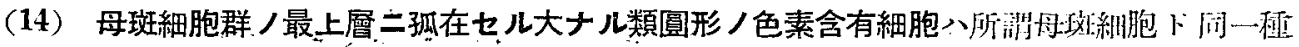

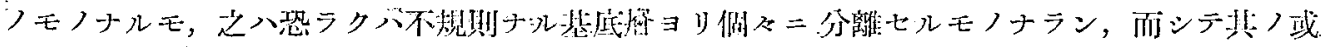

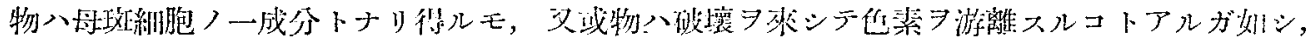

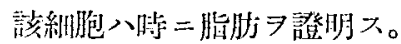

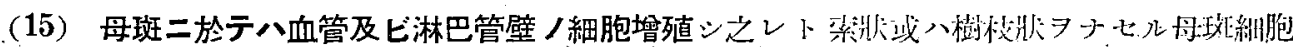

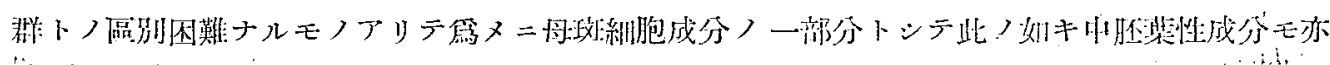

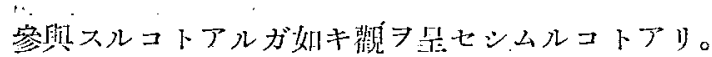

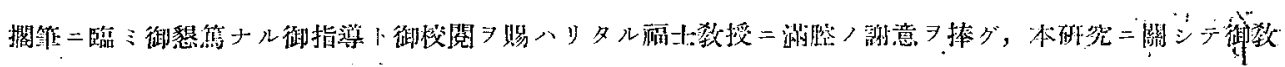

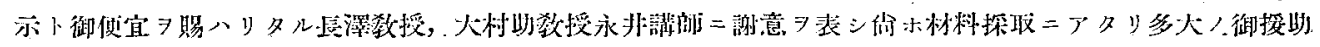

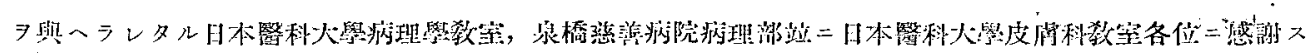

\section{文獻}

1. Aschoff; Lehrbuch d. l'ath. Anatomie. 2. Abesser; Über d. Herkunft u. Bedeutung d. in d. sog. Naevi d. Haut vorkommenden Zellhaufen. (Virch. Arch. f. Path. Bd. 166. S. 40, 1001) 3. Anitschkow; Fur Lehre d. feinsten Struktur der epidermalen Zellen d. Haut in norm u.. Path. Zustande (Franhf. Zeitochrift. f. Path. Bd. VI, 1911) 4. Bauer; Endotheliale Naevi. (Virch. Areh, f, Path, Bd. 142, 1895) 5. Becker; Ursprung u. Latur d. Pigmentierten Naevi ; Schwannome- (Arch. of Dermatolgy and Syplilology Bd. 30, No. 6. 1984-Derm, Wochenschrift. Bd. 100. s. 350) 6. Berblinger; Win Beitrag zur epithelialen Melamin (Virch, Arch, f. Path, Bd. 219, s. 328 1915) 7. Borst; Lehre v. d. Geschwillsten 1902. 8. Bjärneboe; Primäres Melinosareom d. Gehirns, massenhafte Naevi Pigmentosi d. Haut; ausgedehnte Neurofibromatose d. Fiautnerven (Frankf. Zeitsch. f, Path, Bd. 47. H. 3. s. 363. 1934) 9. Browicz; Zur Frage d. Herkunft d. Pigments in Melanotischen Neubildungen (Centralbl f. allg. Path u. Path Anatomie Bd. XII, s. 164. 1901) 10. Caspary; Pathogenese d. Pigmentierung u. Entpigneutierung d. Haut (Centralbl. f. allg. Path u. Anat. Bd. 1. s. 630, 1890) 11. Dalla Favera; Fin Beitrag f. Kentnisse d. Pigmentnaevi (Zieglers Beitrïge z. Path Anat. u. allg. Path. Bd. 43. s. 43. 1908) 12. Demiéville; Über d. Pigmentfleche d. Fraut (Virch. Arch. f. Path, Bd, 81. s. 330, 1880)

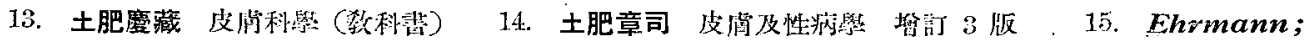
Pathogenese d. Pigmentierung u. Entpigmentierung d. J-Lant (Ceutralblatt f. allg. Path. u. Path. Anatomie Bd. I. s. 641, 1890) 16. Frieboer; $\Lambda$ tlas d. Hiut-u-Geschlechtskr. (Lehrbuch) 17. Grahl; Angeborener, ausgedehnten Naevius Pigmentosus in Verbindung mit Pigmentflecke im Gehirn (Zieglers Beitrag zur Path $\Lambda$ nat. u allg, Bd. XXXIX, s: 66, 1906) 18. Green; Über Naevi Pigmentosi u deren Beziehung zur Melanosarcom. (Virch. Arch. f. Path, Bd. 134, s. 331, 1893) 19. Guazzieri, Gennaro; Melenoblasti c cromatofori nell istogenesi dei nei Pigmentari (Histogenese d. Melanoblasten u. Chromatophoren in d. Pigmentnaevi; (Referat. Centralbl. Hiznt u. Geschle-

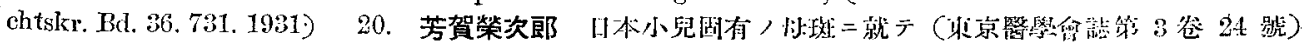
21. 速水 猛 㨅理鼠總諭 22. Hueck; Über d. Pigment (Zieglers Beitrag z. Puth, Anat. Bd.

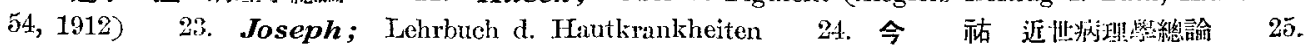

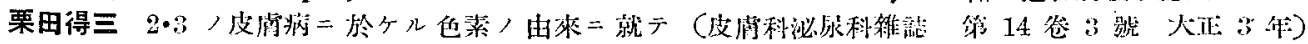
26. Kaposi; Pathogenese d. Pigmentierung u. Entpigmentierung d. Haut. (Centralbl. d. Path. Bd. 1. s. 640. 1890) 27. Kreibich; Über Melanoblasten (Berl. klin. Wochenschr. Nr. 34. 1911) 28. Kromayer; Zur Histogenese d. Weichen Hautnaevi (Centralbl. f. allg. Path. u. Path. Anatomie. Bd. 7, s. 63,1896 ) 29. Krompecher; Über Verbindung, Übergange u Unwandlung zwischen IEpithel, Endothel u Binderewebe, bei embryonem, méderen Wirbeltiere u geschwiilste (Ziegles Beitrag, z, Path, Bd. 34. s. 29. 1905) 30. Löwenbach; Histogenese d. Weichen Natevie ( $\Lambda^{\mathrm{irch}}$, Arch, f. Path, Bd, 15̃7, 1899) 31. Meyerson; Zur Pigmentfrage (Virch, Arch, f. Path, Bd. 116, 1889) 32. Mertsching; Fistologische Studien uber Kertohyalin u Pigment (Virch, Arch, Bd, 
116, 1889) 35. Miescher; Umwandlung ron Naevuszellen in Talgdrusenzelleu (Arch, f, Derm, ii Syphilis Bd, 171. H, .. 1935) 34. Miescher; Ein Beitrag zur epithalialen Genese d. malignen Melanome d. Haut (Centralbl, d. Haut-u-Geschlechtskr. Bd. 30, 355, 1919) 35. 中村朝吉 色素二

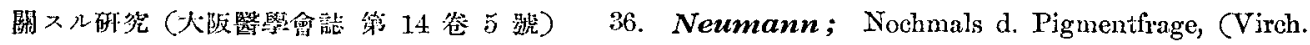
Arch, Bd. 17\%, 1904) 37. Nicolan; Sur le phénonaén migration cellulaire intraepilermique dans le naevocarcinome-a propos de l' etude de.3 tumeurs de Metastase (Über d. Phonomen d. intraepithelialen Zellveränderung beim Naevus carcinom-Untersuchung an Hautmetastase; Ref. Centralbl. d. Haut-u-geschlechtskr, Bd. 35. 511, 1931) 38. Oppenheimer; Beitrïge zur-Lehre d. Pigmentbildung in melanotischer Geschwulste (Virch, Arch. Bd. 106. 515, 1886) 39. Post; Über d. norm u. Path. Pigmentierung d. Oberhantgebilde (Virch, Arch, Bd. 135, 479. 1894) 40. Pochisow; Zur Histogenese d. Naevi Pigmentose d. Bindehaut u. d Lidhaut (Ref. Centralbl. f. Haut-u-Geschtskr, Bd. 55, 646. 1931) 41. Ribbert; Das Melanosarcom (Ziegles Beitrag z. Path-Anat-u allg, Path Bd. 21, 1897) 42. Riecke; Zur Naevuffrage (Arch. f. Derm. u,s Bd. 64, 1903) 43. Rossle; Uber d. Verwandschaft. d. haemaitogenen u autochtonen Pigmente u. deren Stellung zum sog. Flaemosiderin (Virch, Arch, Jd, 115, 1859) 44. Scheuber; Über d. Ursprung d. weichen Naevi (Arch. f. Derm. u-Syphilis Bd. 44, 1898) 45. Schmidt; Über d. Haemosiderin u. Melamin (Virch,

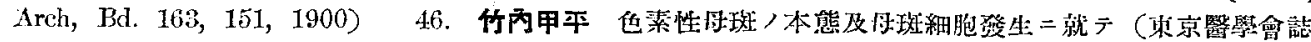
第 35 谷 19 啺) 47. Unna; Naevi u Naevocarcinom (Berl, Klin, Wochenschr. 1893) 48. Virchow; Das Path, Pigment (Virch, Arch, Bd. 1,1894)

\section{附 圖說明}

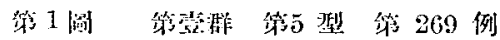

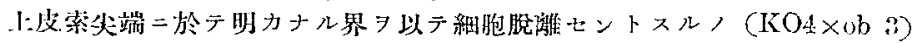

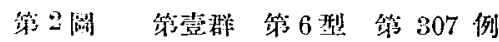

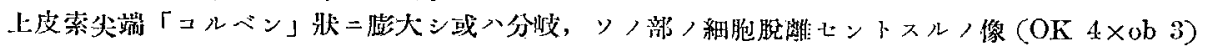

第3间第式群 第 1 型 340 例

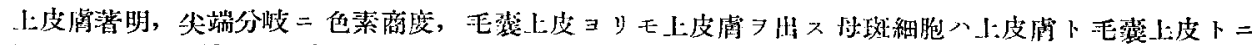
關係アルノ像 (OK 4: $\times$ Of 3 )

第 4 圆 第武群 第 2 型 第 360 )例

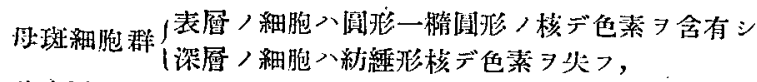

基底屏細胞，配列筑レル像 (OK $4 \times \mathrm{Ob} 3$ )

第5 5 圖 第式称 策 4 型 第 419 例

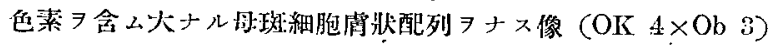

第 6 圆 第武群 第 6 型 第 437 例

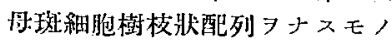

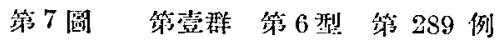

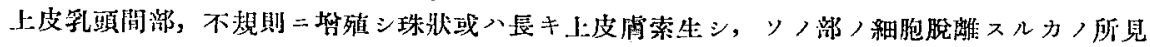

符 8 圆第武群 第 3 型 策 34 例

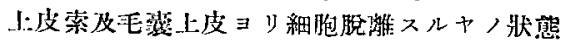

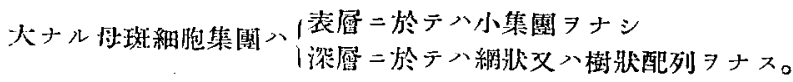

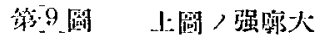

第 10 圆第武群 第3 型 第 394 例

基底厤稩脃，配列不整（强郋火）

第; 11 圆第氠犁 4 型第 423 例

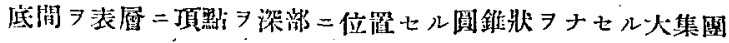

第 12 圆 第式群 第 4 型 第 426 例

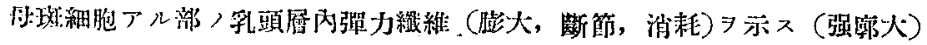


風間論文附圖
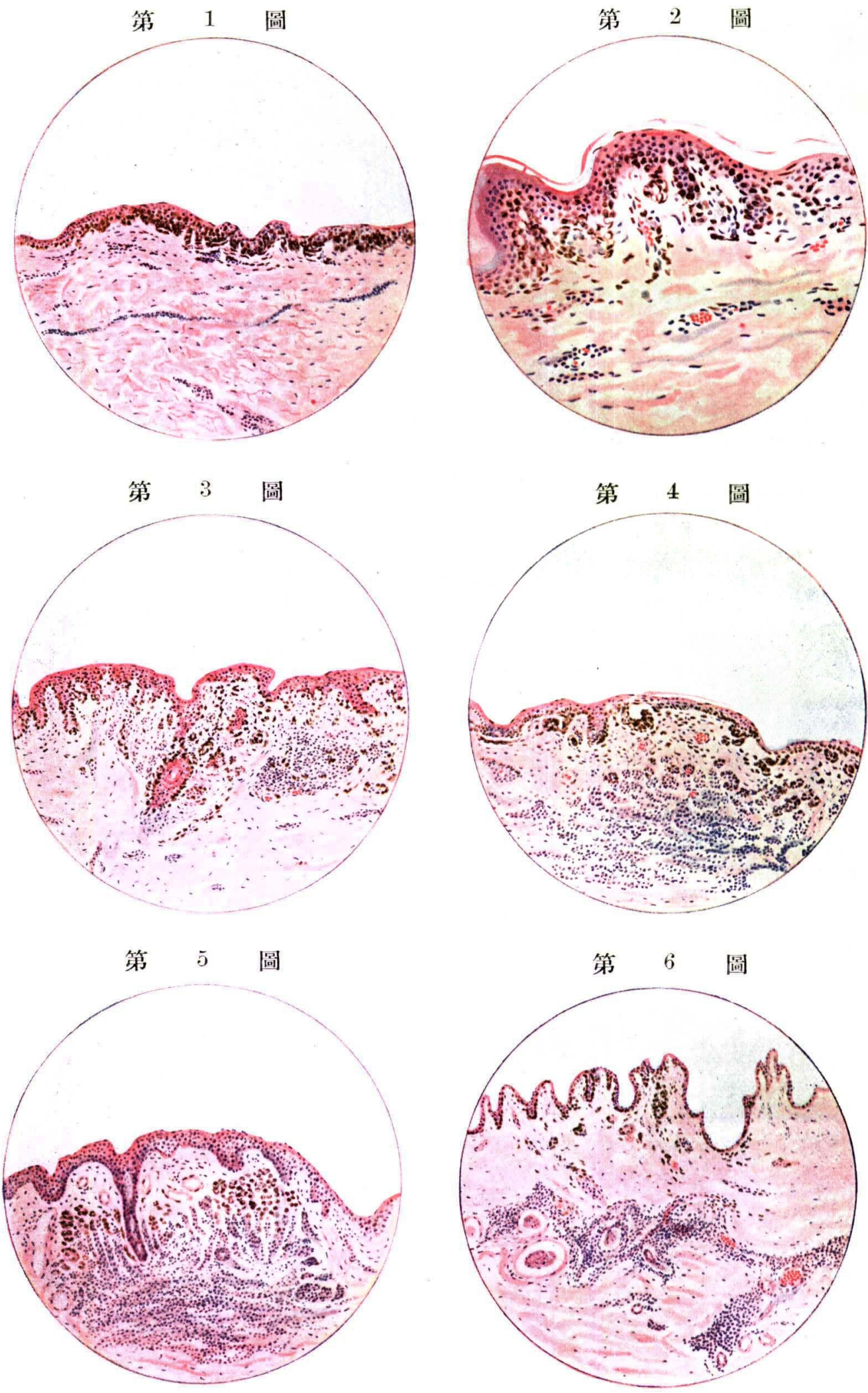

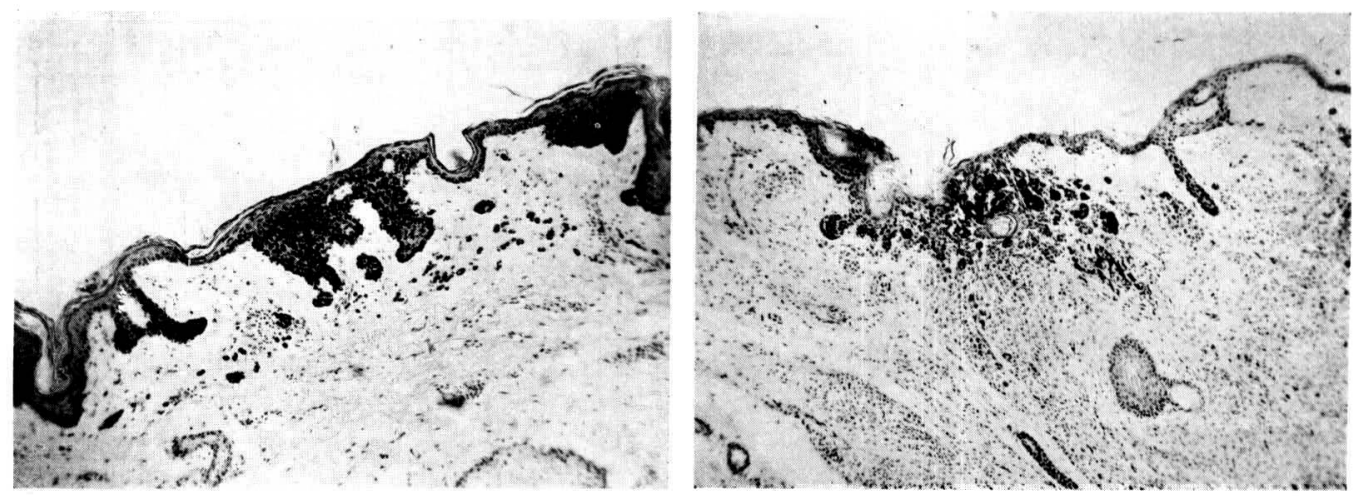

符 9 㘣

第 10 圖
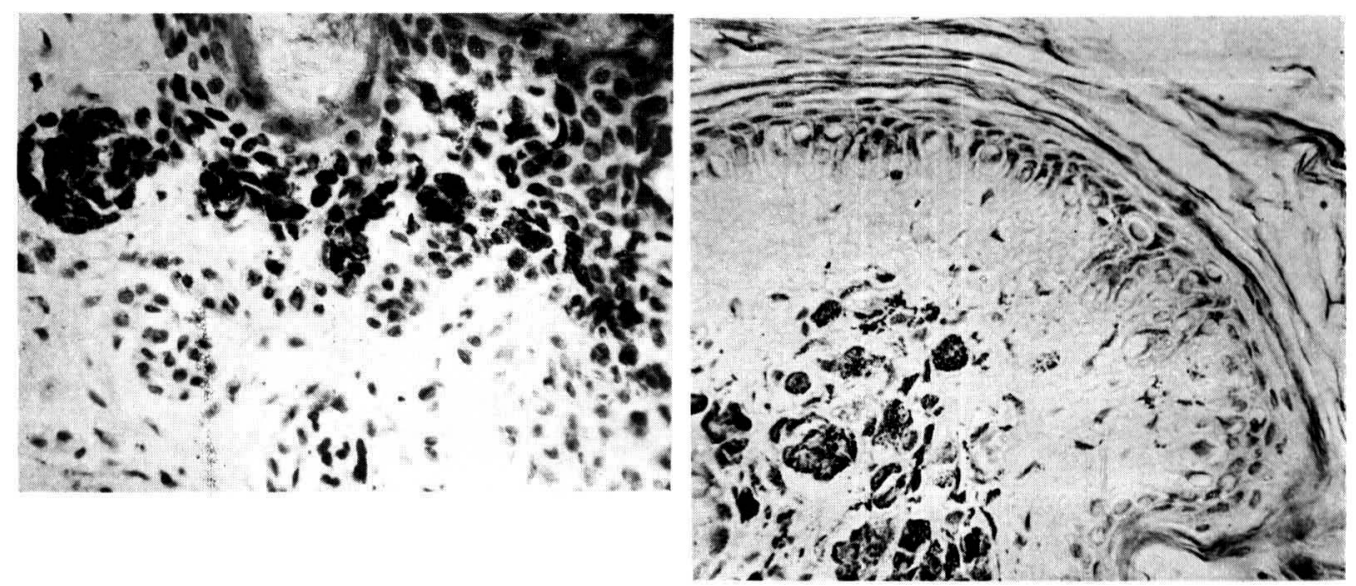

第 11 阔

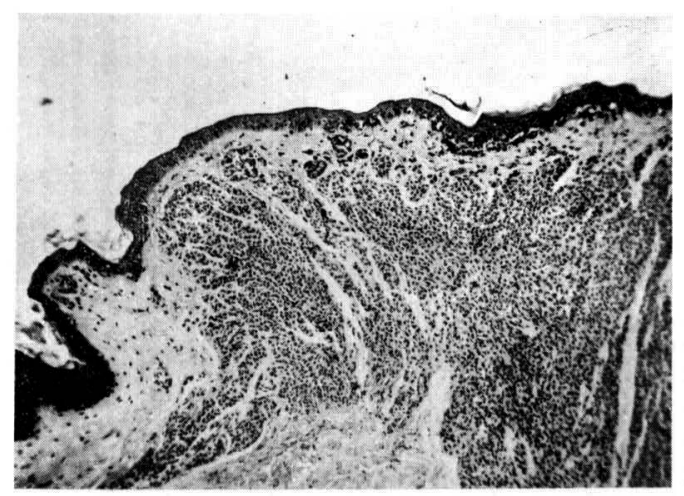

第 12 湔

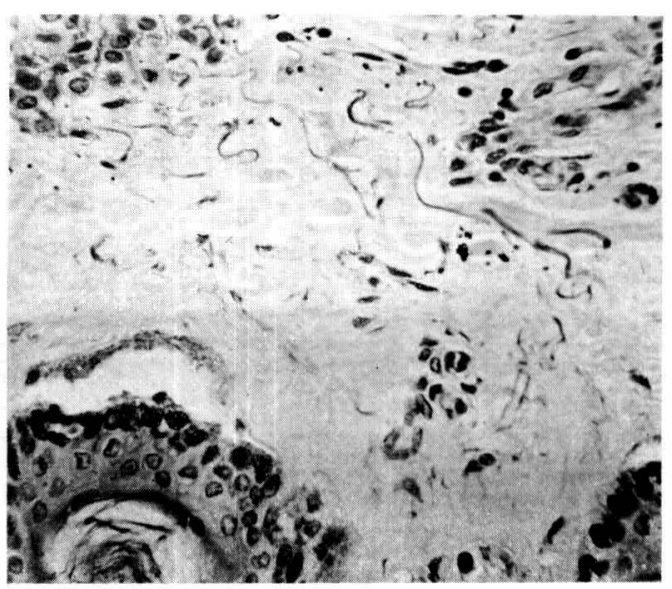

